Page 1 of $Z$

\begin{tabular}{|lr|}
\hline 2. ECN Category & \\
(mark one) & \\
Supplemental & {[]} \\
Direct Revision & {$[x]$} \\
Change ECN & {[]} \\
Temporary & {[]} \\
Standby & {[]} \\
Supersedure & {$[1$} \\
Cancel/Void & {[]}
\end{tabular}

3. Originator's Nane, Organization, MSIN, and Telephone Ho.

J. G. Field, Evaluation and

Planning, R2-12, 376-3753

6. Project Title/Mo./Work order No.

T-105 TCR

9. Document Numbers Changed by this ECN (includes sheet no, and rev.) WHC-SD-WM-ER-369, Rev. 0

\begin{tabular}{|l|l|}
\hline $\begin{array}{l}\text { 4. USQ Required? } \\
{[] \text { Yes [X] No }}\end{array}$ & $\begin{array}{l}\text { 5. Date } \\
1 / 20 / 97\end{array}$ \\
\hline $\begin{array}{l}\text { 7. Bldg./Sys./Fac. No. } \\
\text { 10. Related ECN No(s). } \\
\text { EDT } 159082\end{array}$ & $\begin{array}{c}\text { Approval Designator } \\
\text { N/A Related PO No. }\end{array}$ \\
\hline
\end{tabular}

12a. Modification Work

12b. Work Package $12 c$. Modification Work Complete No.

12d. Restored to Original Condi

[] res (fill out $B l k$. 12b)

[X] No (NA Blks. 12b, $12 c, 12 d)$

$N \mid \mathbf{A}$

$N \mid A$

$N \mid A$

Design Authority/Cog. Engineer Signature \& Date

$t$ ion (Temp. or standby ECN only)

13a. Description of Change

13b. Design Basel ine Document?

Revised to new format per DOE performance agreements

14a. Justification (mark one)

Criteria Change [] Design Improvement [] Environmental

As-Found [X]

Facilitate Const

[]

Const. Error/Omission

[]

Facility Deactivation

Design Error/Omission

[]

14b. Justification Details

Revised per DOE performance agreement and direction from the Washington State

Department of Ecology to revise 23 TCR's (letter dated 7/6/1995).

15. Distribution (include name, MSIN, and no. of copies)

Attached

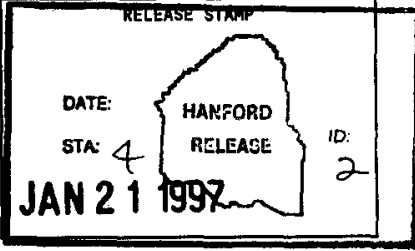

A-7900-013-2 (05/96) GEF095 
THIS PAGE INTENTIONALLY LEFT BLANK 


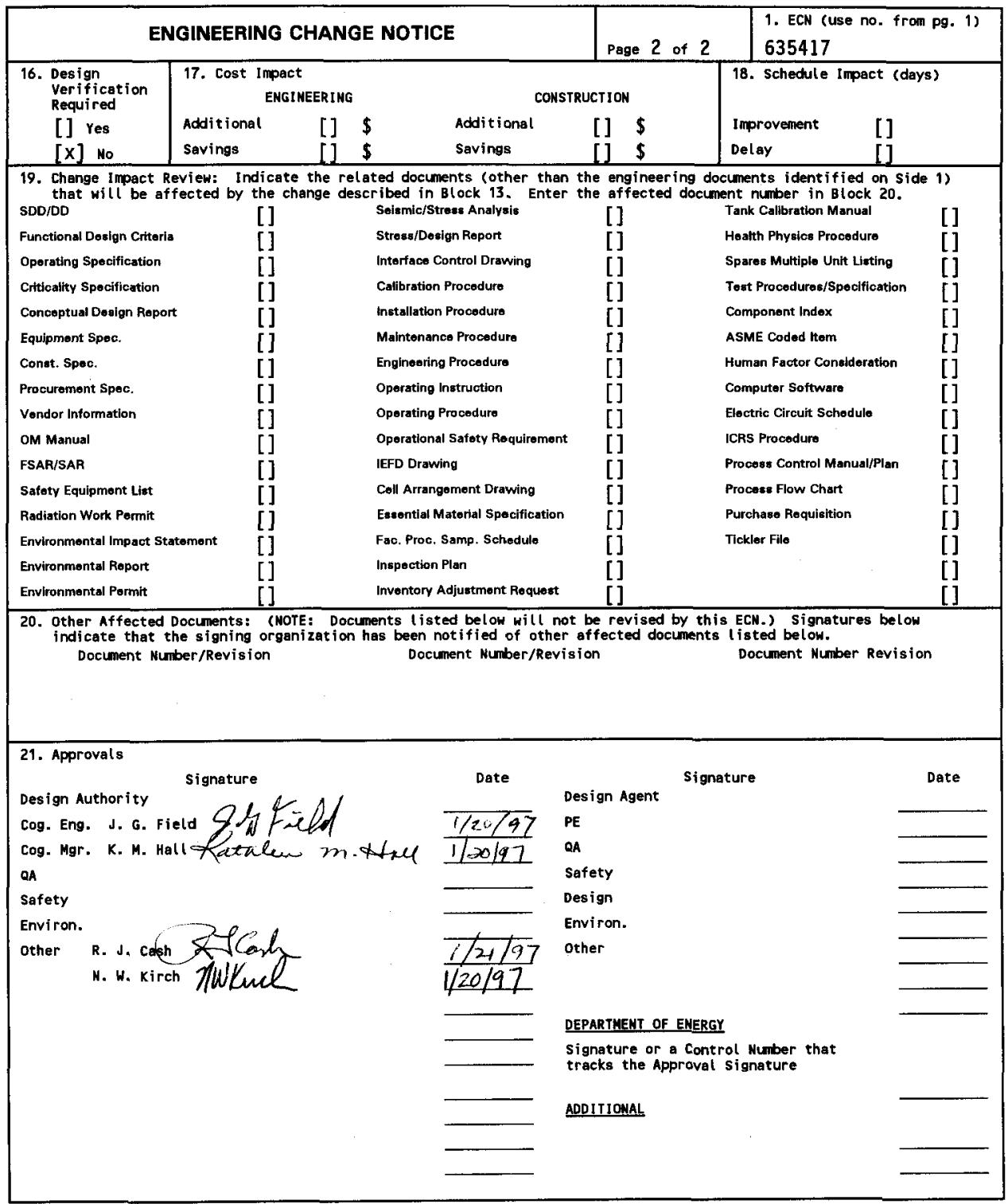


THIS PAGE INTENTIONALLY

LEFT BLANK 


\title{
Tank Characterization Report for Single-Shell Tank 241-T-105
}

\author{
J. G. Field
}

Lockheed Martin Hanford Company, Richland, WA 99352

U.S. Department of Energy Contract DE-AC06-87RL10930

\author{
EDT/ECN: 635417 \\ Org Code: 74610 \\ UC: 2070 \\ B\&R Code: EW3120074 \\ Charge Code: E61977 \\ Total Pages: 171
}

Key Words: Tank 241-T-105, T-105, T Farm, Tank Characterization Report, TCR, Single-Shell Tank, Waste Characterization, Waste Inventory, TPA Milestone M-44

Abstract: This document summarizes information on historical uses, present status, and the sampling and analysis results of waste stored in Tank 241-T-105, Sampling and Analyses Meet Safety Screening Objectives. This report supports requirements of Tri-Party Agreement Milestone M-44-05.

TRADEMARK DISCLAIMER. Reference herein to any specific commercial product, process, or service by trade name, trademark, manufacturer, or otherwise, does not necessarily constitute or imply its endorsement, recommendation, or favoring by the United States Government or any agency thereof or its contractors or subcontractors.

Printed in the United States of America. To obtain copies of this document, contact: WHC/BCS Document Control Services, P.O. Box 1970, Mailstop H6-08, Richland WA 99352, Phone (509) 372-2420; Fax (509) $376-4989$.
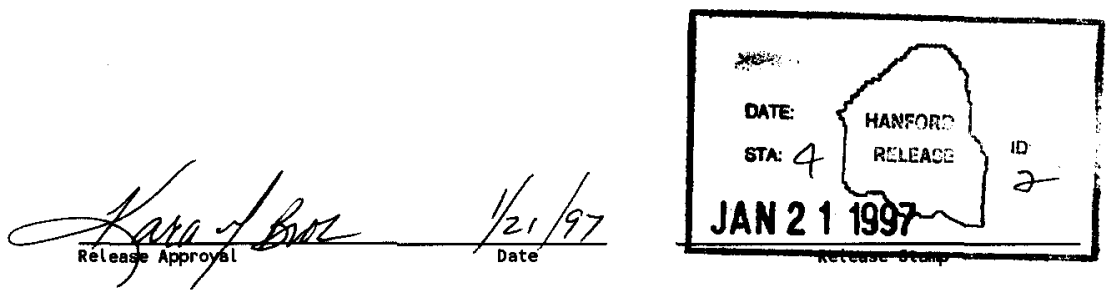

Approved for Public Release 
THIS PAGE INTENTIONALLY LEFT BLANK 


\section{RECORD OF REVISION}

(2) Title

Tank Characterization Report for Single-Shell Tank 241-T-105

CHANGE CONTROL RECORD

\begin{tabular}{|c|c|c|c|c|}
\hline \multirow{2}{*}{ (3) } & \multirow{2}{*}{ Revision } & \multirow{2}{*}{ (4) Description of Change - Replace, Add, and Delete Pages } & \multicolumn{2}{|c|}{ Authorized for Release } \\
\hline & & & (5) Cog. Engr. & (6) Cog. Mgr. Date \\
\hline & 0 & (7) Initially released on EDT 159082 & B. C. Simpson & C. S. Haller \\
\hline & 1 RS & Incorporate per ECN 635417 & J. G. Field & K. M. Hal $\psi$ nilt \\
\hline & & & ditill $1 / 20$ & 3) \\
\hline & & & & \\
\hline & & & & \\
\hline & & & & \\
\hline & & & & \\
\hline & & & & \\
\hline & & & & \\
\hline & & & & \\
\hline & & & & \\
\hline & & & & \\
\hline & & & & \\
\hline & & & & \\
\hline & & & & \\
\hline & & & & \\
\hline & & & & \\
\hline & & & & \\
\hline & & & & \\
\hline & & & & \\
\hline & & & & \\
\hline & & & & \\
\hline & & & & \\
\hline & & & & \\
\hline & & & & \\
\hline & & & & \\
\hline & & & & \\
\hline & & & & \\
\hline & & & & \\
\hline & & & & \\
\hline & & & & \\
\hline & & & & \\
\hline
\end{tabular}


THIS PAGE INTENTIONALLY LEFT BLANK 


\section{Tank Charcterization Report for Single-Shell Tank 241-T-105}

J. G. Field

M. J. Kupfer

Lockheed Martin Hanford Corporation

S. R. Wilmarth

Numatec Hanford Corporation

L. G. Parkhill

Los Alamos Technical Associates

Date Published

January 1997

Prepared for the U.S. Department of Energy

Assistant Secretary for Environmental Management

Project Hanford Manegement Contractor for the

U.S. Department of Energy under Contract DE-AC06-96RL13200

Approved for public release; distribution is unlimited 
THIS PAGE INTENTIONALLY LEFT BLANK 


\section{CONTENTS}

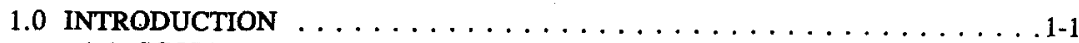

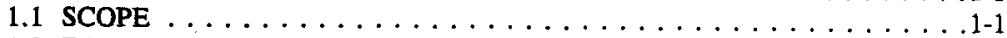

1.2 TANK BACKGROUND $\ldots \ldots \ldots \ldots \ldots \ldots \ldots \ldots \ldots \ldots \ldots$

2.0 RESPONSE TO TECHNICAL ISSUES $\ldots \ldots \ldots \ldots \ldots \ldots \ldots \ldots \ldots \ldots \ldots \ldots$

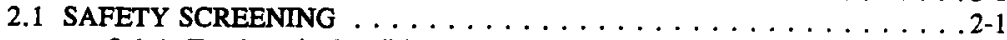

2.1.1 Exothermic Conditions (Energetics) $\ldots \ldots \ldots \ldots \ldots \ldots .2-2$

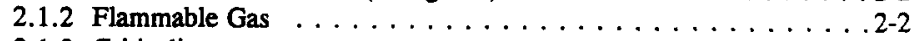

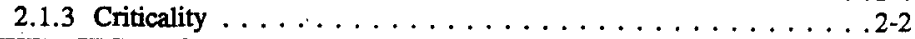

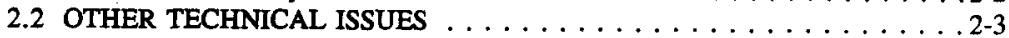

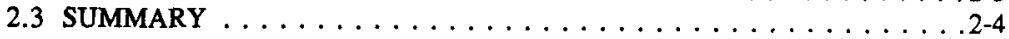

3.0 BEST-BASIS INVENTORY ESTTMATE $\ldots \ldots \ldots \ldots \ldots \ldots \ldots$ 3-1

4.0 RECOMMENDATIONS $\ldots \ldots \ldots \ldots \ldots \ldots \ldots \ldots \ldots \ldots \ldots . \ldots \ldots$

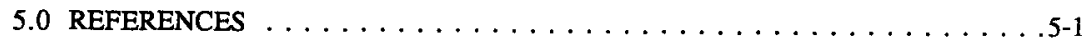

APPENDICES

APPENDIX A HISTORICAL TANK INFORMATION $\ldots \ldots \ldots \ldots \ldots \ldots$ A-1

A1.0 CURRENT TANK STATUS $\ldots \ldots \ldots \ldots \ldots \ldots \ldots \ldots \ldots$ A-3

A2.0 TANK DESIGN AND BACKGROUND $\ldots \ldots \ldots \ldots \ldots \ldots$ A $4 \ldots \ldots$

A3.0 PROCESS KNOWLEDGE $\ldots \ldots \ldots \ldots \ldots \ldots \ldots \ldots \ldots \ldots$ A $\ldots \ldots$

A3.1 WASTE TRANSFER HISTORY $\ldots \ldots \ldots \ldots \ldots \ldots \ldots$ A-9

A3.2 HISTORICAL ESTIMATION OF TANK CONTENTS . . . . . . A A-10

A4.0 SURVEILLANCE DATA $\ldots \ldots \ldots \ldots \ldots \ldots \ldots \ldots \ldots \ldots \ldots$ A-14

A4.1 SURFACE-LEVEL READINGS $\ldots \ldots \ldots \ldots \ldots \ldots \ldots \ldots \ldots$ A-15

A4.2 INTERNAL TANK TEMPERATURES $\ldots \ldots \ldots \ldots \ldots \ldots \ldots$ A-15

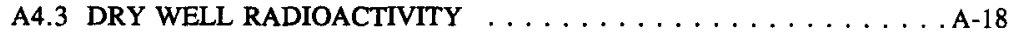

A4.4 TANK 241-T-105 PHOTOGRAPHS $\ldots \ldots \ldots \ldots \ldots \ldots \ldots \ldots$ A-18

A5.0 APPENDIX A REFERENCES $\ldots \ldots \ldots \ldots \ldots \ldots \ldots \ldots \ldots \ldots$. . . . . . . . 


\section{CONTENTS (Continued)}

APPENDIX B SAMPLING OF TANK $241-\mathrm{T}-105 \ldots \ldots \ldots \ldots$ B-1

B1.0 TANK SAMPLING OVERVIEW $\ldots \ldots \ldots \ldots \ldots \ldots \ldots \ldots$ B-3

B1.1 DESCRIPTION OF SAMPLING EVENTS $\ldots \ldots \ldots \ldots \ldots \ldots$ B-3

B1.2 SAMPLE HANDLING $\ldots \ldots \ldots \ldots \ldots \ldots \ldots \ldots$ B-4

B1.2.1 Core $53 \ldots \ldots \ldots \ldots \ldots \ldots \ldots \ldots \ldots \ldots$ B-4

B1.2.2 Core $54 \ldots \ldots \ldots \ldots \ldots \ldots \ldots \ldots \ldots \ldots \ldots \ldots \ldots$

B1.2.3 Core $57 \ldots \ldots \ldots \ldots \ldots \ldots \ldots \ldots \ldots \ldots$ B-5

B1.3 SAMPLE ANALYSIS $\ldots \ldots \ldots \ldots \ldots \ldots \ldots \ldots \ldots$. . . . . . . .

B1.4 DESCRIPTION OF HISTORICAL SAMPLING EVENT $\ldots \ldots \ldots \ldots$ B-10

B2.0 ANALYTICAL RESULTS $\ldots \ldots \ldots \ldots \ldots \ldots \ldots \ldots \ldots$ B-11

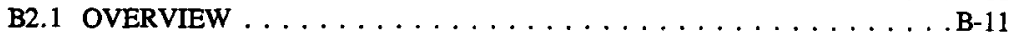

B2.2 INORGANIC ANALYSES $\ldots \ldots \ldots \ldots \ldots \ldots \ldots \ldots \ldots \ldots$ B-12

B2.2.1 Atomic Absorption Spectroscopy . . . . . . . . . . B-13

B2.2.2 Cold Vapor Atomic Absorption Spectroscopy . . . . . . . . . B-13

B2.2.3 Inductively Coupled Plasma $\ldots \ldots \ldots \ldots \ldots \ldots \ldots$. . . . . . . . . .

B2.2.4 Laser Fluorimetry $\ldots \ldots \ldots \ldots \ldots \ldots \ldots \ldots \ldots$ B-13

B2.2.5 Chromium (VI) by Spectrophotometry . . . . . . . . B-13

B2.2.6 Distillation/Titration . . . . . . . . . . . . . B-13

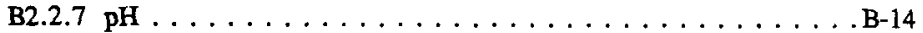

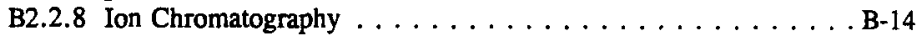

B2.2.9 Potentiometric Titration . . . . . . . . . . . . . B-14

B2.2.10 Distillation/Spectrometry . . . . . . . . . . . B-14

B2.2.11 Nitrite by Spectrophotometry $\ldots \ldots \ldots \ldots \ldots \ldots \ldots$ B-14

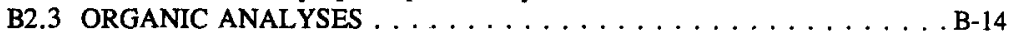

B2.4 CARBON ANALYSES $\ldots \ldots \ldots \ldots \ldots \ldots \ldots \ldots \ldots \ldots$

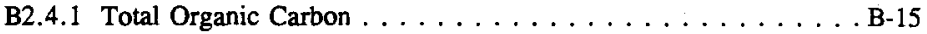

B2.4.2 Total Inorganic Carbon . . . . . . . . . . . . . B-15

B2.5 RADIONUCLIDE ANALYSES $\ldots \ldots \ldots \ldots \ldots \ldots \ldots \ldots \ldots$ B-15

B2.5.1 Mass Spectroscopy $\ldots \ldots \ldots \ldots \ldots \ldots \ldots \ldots \ldots$ B-15

B2.5.2 Total Alpha and Alpha Emitters $\ldots \ldots \ldots \ldots \ldots \ldots$ B-15

B2.5.3 Total Beta Activity . . . . . . . . . . . . . B-16

B2.5.4 Gamma Energy Analysis . . . . . . . . . . . . . B-16

B2.5.5 Liquid Scintillation Counting $\ldots \ldots \ldots \ldots \ldots \ldots \ldots$ B-16

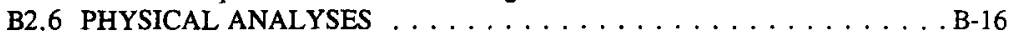

B2.6.1 Percent Solids, Density, and Specific Gravity . . . . . . . B-16

B2.6.2 Total Dissolved Solids . . . . . . . . . . . . . . B-17

B2.6.3 Particle Size . . . . . . . . . . . . . . . . B-17

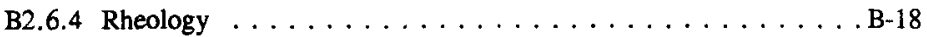

B2.7 THERMODYNAMIC ANALYSES $\ldots \ldots \ldots \ldots \ldots \ldots \ldots$ B-18 


\section{CONTENTS (Continued)}

B2.7.1 Differential Scanning Calorimetry . . . . . . . . . . . B-18

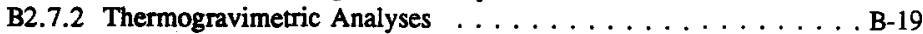

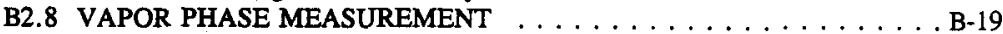

B2.9 HISTORICAL SAMPLE RESULTS . . . . . . . . . . . . . B

B3.0 ASSESSMENT OF CHARACTERIZATION RESULTS $\ldots \ldots \ldots \ldots \ldots$ B-60

B3.1 GENERAL OBSERVATIONS . . . . . . . . . . . . B-60

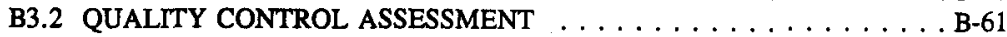

B3.3 DATA CONSISTENCY CHECKS . . . . . . . . . . . . B-61

B3.3.1 Comparison of Results from Different Analytical Methods . . . B B-62

B3.3.2 Mass and Charge Balances .............. B-63

B3.4 CALCULATION OF ANALYTICAL BASED MEANS $\ldots \ldots \ldots \ldots$ B-66

B4.0 APPENDIX B REFERENCES $\ldots \ldots \ldots \ldots \ldots \ldots \ldots \ldots \ldots \ldots$. . . . . . .

APPENDIX C STATISTICAL ANALYSIS FOR ISSUE RESOLUTION $\ldots \ldots \ldots \ldots$ C-1

APPENDIX D EVALUATION TO ESTABLISH BEST-BASIS INVENTORY FOR

SINGLE-SHELL TANK $241-T-105 \ldots \ldots \ldots \ldots \ldots \ldots$. $\ldots \ldots$

D1.0 IDENTIFY/COMPILE INVENTORY SOURCES $\ldots \ldots \ldots \ldots \ldots$ D-3

D2.0 COMPARE COMPONENT INVENTORY VALUES AND NOTE

SIGNIFICANT DIFFERENCES $\ldots \ldots \ldots \ldots \ldots \ldots \ldots \ldots$ D-3

D3.0 REVIEW AND EVALUATION OF COMPONENT INVENTORIES $\ldots \ldots \ldots$ D-7

D3.1 CONTRIBUTING WASTE TYPES . . . . . . . . . . . . D-7

D3.2 EVALUATION OF TECHNICAL FLOWSHEET INFORMATION . . . . D-9

D3.3 ASSUMPTIONS FOR RECONCILING WASTE INVENTORIES . . . . D-10

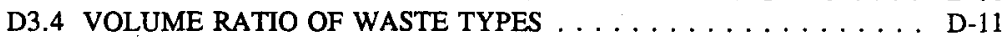

D3.5 METHODOLOGY FOR ESTIMATING TANK 241-T-105

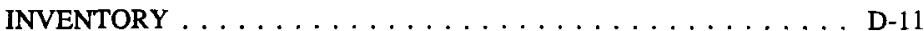

D3.6 ESTIMATED INVENTORY OF COMPONENTS $\ldots \ldots \ldots \ldots \ldots$ D-14

D4.0 DEFINE THE BEST-BASIS AND ESTABLISH

COMPONENT INVENTORIES $\ldots \ldots \ldots \ldots \ldots \ldots \ldots \ldots$ D-18

D5.0 APPENDIX D REFERENCES $\ldots \ldots \ldots \ldots \ldots \ldots \ldots \ldots \ldots \ldots$ D-23

APPENDIX E BIBLIOGRAPHY FOR TANK $241-\mathrm{T}-105 \ldots \ldots \ldots \ldots$ E-1 


\section{LIST OF FIGURES}

3-1 Schematic of 1C, 2C and CW Waste Contributions for Tank 241-T-105 Best

Basis Inventory Estimates, and Representative Tanks for Each Waste Type . . . . 3-2

A2-1 Riser Configuration for Tank 241-T-105 . . . . . . . . . . . . . . . A A-6

A2-2 Tank 241-T-105 Cross-Section and Schematic . . . . . . . . . . . A-8

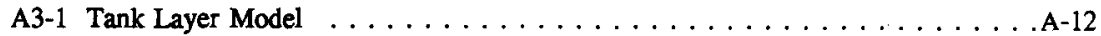

A4-1 Tank 241-T-105 Level History $\ldots \ldots \ldots \ldots \ldots \ldots \ldots \ldots \ldots \ldots$. . . . . . . . . . . .

A4-2 Tank 241-T-105 High Temperature Plot . . . . . . . . . . . . . A-17 


\section{LIST OF TABLES}

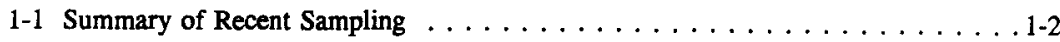

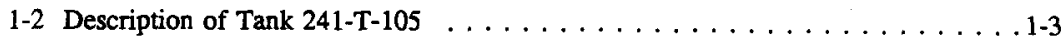

2-1 Tank 241-T-105 Projected Heat Load $\ldots \ldots \ldots \ldots \ldots \ldots . \ldots \ldots$ 2-3

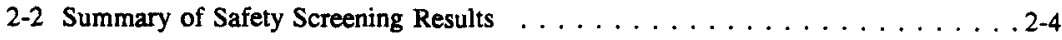

3-1 Best-Basis Inventory Estimates for Nonradioactive Components in Tank 241-T-105 (September 30, 1996) . . . . . . . . . . . . . 3-4

3-2 Sample-Based Best-Basis Inventory Estimates for Radioactive Components for Tank 241-T-105 (All Curie Values Decayed to January 1, 1994) . . . . . . 3-6

4-1 Acceptance of Tank 241-T-105 Sampling and Analysis $\ldots \ldots \ldots$. . . . . .

4-2 Acceptance of Evaluation of Characterization Data and Information for Tank $241-\mathrm{T}-105 \ldots \ldots \ldots \ldots \ldots \ldots \ldots \ldots \ldots .2$

A1-1 Tank 241-T-105 Contents Status Summary . . . . . . . . . A-4

A2-1 Tank 241-T-105 Risers $\ldots \ldots \ldots \ldots \ldots \ldots \ldots \ldots \ldots$ A-7

A3-1 Tank 241-T-105 Major Transfers ${ }^{1.2} \ldots \ldots \ldots \ldots \ldots \ldots \ldots$ A-11

A3-2 Historical Tank Inventory Estimate $\ldots \ldots \ldots \ldots \ldots \ldots \ldots \ldots$ A-13

B1-1 Waste Characteristics Comparison $\ldots \ldots \ldots \ldots \ldots \ldots \ldots \ldots$ B-6

B1-2 Analyses Performed on the Solids (by Segment) $\ldots \ldots \ldots \ldots \ldots$ B-8

B1-3 Analyses Performed on the Drainable Liquid (by Segment) . . . . . . . B B-9

B1-4 Inorganic and Radiochemical Analytical Methods . . . . . . . . . . B B-9

B1-5 Physical and Rheological Analytical Methods . . . . . . . . . B-10

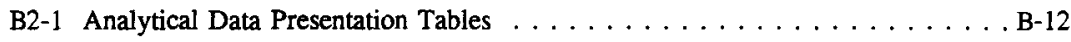

B2-2 Tank 241-T-105 Analytical Results: Cesium (Atomic Absorption) . . . . . . . B-20

B2-3 Tank 241-T-105 Analytical Results: Mercury (CVAA) . . . . . . . . . . B-20 


\section{LIST OF TABLES (Continued)}

B2-4 Tank 241-T-105 Analytical Results: Aluminum (ICP) $\ldots \ldots \ldots \ldots \ldots$. . . . . . .

B2-5 Tank 241-T-105 Analytical Results: Antimony (ICP) $\ldots \ldots \ldots \ldots \ldots$. . . . . .

B2-6 Tank 241-T-105 Analytical Results: Arsenic (ICP) $\ldots \ldots \ldots \ldots \ldots$. . . . B-21

B2-7 Tank 241-T-105 Analytical Results: Beryllium (ICP) $\ldots \ldots \ldots \ldots \ldots \ldots$ B-22

B2-8 Tank 241-T-105 Analytical Results: Bismuth (ICP) . . . . . . . . . . B-22

B2-9. Tank 241-T-105 Analytical Results: Boron (ICP) $\ldots \ldots \ldots \ldots \ldots \ldots$. . . . . . .

B2-10 Tank 241-T-105 Analytical Results: Cadmium (ICP) . . . . . . . . . B-23

B2-11 Tank 241-T-105 Analytical Results: Calcium (ICP) $\ldots \ldots \ldots \ldots \ldots$. . . . . .

B2-12 Tank 241-T-105 Analytical Results: Cerium (ICP) $\ldots \ldots \ldots \ldots \ldots$. . . . . . . .

B2-13 Tank 241-T-105 Analytical Results: Chromium (CP) $\ldots \ldots \ldots \ldots \ldots$. . . . . .

B2-14 Tank 241-T-105 Analytical Results: Iron (ICP) $\ldots \ldots \ldots \ldots \ldots \ldots$. . . . . . . .

B2-15 Tank 241-T-105 Analytical Results: Lanthanum (ICP) . . . . . . . . . B-26

B2-16 Tank 241-T-105 Analytical Results: Lead (ICP) . . . . . . . . . B-26

B2-17 Tank 241-T-105 Analytical Results: Lithium (ICP) . . . . . . . . . . . B-27

B2-18 Tank 241-T-105 Analytical Results: Magnesium (ICP) $\ldots \ldots \ldots \ldots \ldots$ B-27

B2-19 Tank 241-T-105 Analytical Results: Manganese (ICP) . . . . . . . . B-28

B2-20 Tank 241-T-105 Analytical Results: Molybdenum (ICP) $\ldots \ldots \ldots \ldots$. . . . .

B2-21 Tank 241-T-105 Analytical Results: Neodymium (ICP) . . . . . . . . . . . B-29

B2-22 Tank 241-T-105 Analytical Results: Nickel (ICP) . . . . . . . . . . B-29

B2-23 Tank 241-T-105 Analytical Results: Phosphorus (ICP) $\ldots \ldots \ldots \ldots \ldots$. . . . . .

B2-24 Tank 241-T-105 Analytical Results: Potassium (ICP) $\ldots \ldots \ldots \ldots \ldots$. . . . . . . 


\section{LIST OF TABLES (Continued)}

B2-25 Tank 241-T-105 Analytical Results: Samarium (ICP) $\ldots \ldots \ldots \ldots \ldots$. . . . .

B2-26 Tank 241-T-105 Analytical Results: Selenium (ICP) . . . . . . . . . B-31

B2-27 Tank 241-T-105 Analytical Results: Silicon (ICP) . . . . . . . . . . B-32

B2-28 Tank 241-T-105 Analytical Results: Silver (ICP) . . . . . . . . . B-32

B2-29 Tank 241-T-105 Analytical Results: Sodium (ICP) . . . . . . . . . . B-33

B2-30 Tank 241-T-105 Analytical Results: Strontium (ICP) $\ldots \ldots \ldots \ldots$. . . B-33

B2-31 Tank 241-T-105 Analytical Results: Sulfur (ICP) . . . . . . . . . . B B-34

B2-32 Tank 241-T-105 Analytical Results: Thallium (ICP) . . . . . . . . . . . B-34

B2-33 Tank 241-T-105 Analytical Results: Titanium (ICP) $\ldots \ldots \ldots \ldots \ldots$. . . . . . .

B2-34 Tank 241-T-105 Analytical Results: Zirconium (ICP) $\ldots \ldots \ldots \ldots$. . . . . .

B2-35 Tank 241-T-105 Analytical Results: Total Uranium (Laser Fluorimetry) . . . . B-36

B2-36 Tank 241-T-105 Analytical Results: Hexavalent Chromium $(\mathrm{Cr}+6) \ldots \ldots$ B-36

B2-37 Tank 241-T-105 Analytical Results: Ammonium (Distillation) . . . . . . . B-36

B2-38 Tank 241-T-105 Analytical Results: $\mathrm{pH}$ Measurement $(\mathrm{pH}) \ldots \ldots \ldots \ldots$ B-37

B2-39 Tank 241-T-105 Analytical Results: Chloride (IC) $\ldots \ldots \ldots \ldots \ldots$. . . . . . .

B2-40 Tank 241-T-105 Analytical Results: Fluoride (IC) $\ldots \ldots \ldots \ldots \ldots$. . . . . . .

B2-41 Tank 241-T-105 Analytical Results: Nitrate (IC) $\ldots \ldots \ldots \ldots \ldots \ldots$. . . . . .

B2-42 Tank 241-T-105 Analytical Results: Nitrite (IC) $\ldots \ldots \ldots \ldots \ldots \ldots$. . . . . . . .

B2-43 Tank 241-T-105 Analytical Results: Phosphate (IC) $\ldots \ldots \ldots \ldots \ldots \ldots$. . . . . . .

B2-44 Tank 241-T-105 Analytical Results: Sulfate (IC) $\ldots \ldots \ldots \ldots \ldots \ldots$. . . . . .

B2-45 Tank 241-T-105 Analytical Results: Hydroxide (Titration) . . . . . . . . B-39 


\section{LIST OF TABLES (Continued)}

B2-46 Tank 241-T-105 Analytical Results: Cyanide (Distillation/Spectrometry) . . . . . B-39

B2-47 Tank 241-T-105 Analytical Results: Nitrite (Spectrophotometric) . . . . . . . B-40

B2-48 Tank 241-T-105 Analytical Results: Total organic carbon (Furnace Oxidation) . B-40

B2-49 Tank 241-T-105 Analytical Results: Total organic carbon

(Persulfate Oxidation) $\ldots \ldots \ldots \ldots \ldots \ldots \ldots \ldots \ldots$. . . . . . . . . . . .

B2-50 Tank 241-T-105 Analytical Results: Total Inorganic Carbon

(Persulfate Oxidation) $\ldots \ldots \ldots \ldots \ldots \ldots \ldots \ldots \ldots \ldots$. $\ldots \ldots 1$

B2-51 Tank 241-T-105 Analytical Results: Total Inorganic Carbon (TIC) . . . . . . B-41

B2-52 Tank 241-T-105 Analytical Results: Pu238 to Pu ratio (Mass Spec) . . . . . B-41

B2-53 Tank 241-T-105 Analytical Results: Pu239 to Pu ratio (Mass Spec) . . . . B-42

B2-54 Tank 241-T-105 Analytical Results: Pu240 to Pu ratio (Mass Spec) $\ldots \ldots$. B-42

B2-55 Tank 241-T-105 Analytical Results: Pu241 to Pu ratio (Mass Spec) . . . . . B-42

B2-56 Tank 241-T-105 Analytical Results: Pu242 to Pu ratio (Mass Spec) . . . . B B-42

B2-57 Tank 241-T-105 Analytical Results: U234 to U ratio (Mass Spec) . . . . . B-42

B2-58 Tank 241-T-105 Analytical Results: U235 to U ratio (Mass Spec) $\ldots \ldots \ldots$. B-43

B2-59 Tank 241-T-105 Analytical Results: U236 to U ratio (Mass Spec) . . . . . B-43

B2-60 Tank 241-T-105 Analytical Results: U238 to U ratio (Mass Spec) . . . . . B-43

B2-61 Tank 241-T-105 Analytical Results: Total Alpha (Alpha Rad) . . . . . . . B-43

B2-62 Tank 241-T-105 Analytical Results: Total alpha Pu (Alpha Rad) . . . . . . . B-44

B2-63 Tank 241-T-105 Analytical Results: Americium-241 (Alpha Spec) . . . . . B-44

B2-64 Tank 241-T-105 Analytical Results: Plutonium-238 (Alpha Spec) . . . . . . . B-44

B2-65 Tank 241-T-105 Analytical Results: Plutonium-239/40 (Alpha Spec) . . . . . B-44 


\section{LIST OF TABLES (Continued)}

B2-66 Tank 241-T-105 Analytical Results: Total Beta (Beta Proportional Counting) . . B-45

B2-67 Tank 241-T-105 Analytical Results: Strontium-90

(Beta Proportional Counting) $\ldots \ldots \ldots \ldots \ldots \ldots \ldots \ldots \ldots$. . . . . . . . . .

B2-68 Tank 241-T-105 Analytical Results: Americium-241 (GEA) . . . . . . . . B-46

B2-69 Tank 241-T-105 Analytical Results: Antimony-125 (GEA) $\ldots \ldots \ldots \ldots$. . . . . .

B2-70 Tank 241-T-105 Analytical Results: Ce/Pr-144 (GEA) $\ldots \ldots \ldots \ldots \ldots$. .47

B2-71 Tank 241-T-105 Analytical Results: Cesium-134 (GEA) $\ldots \ldots \ldots \ldots \ldots$ B-47

B2-72 Tank 241-T-105 Analytical Results: Cesium-137 (GEA) $\ldots \ldots \ldots \ldots$. . . B-48

B2-73 Tank 241-T-105 Analytical Results: Cobalt-60 (GEA) $\ldots \ldots \ldots \ldots$. . . B-48

B2-74 Tank 241-T-105 Analytical Results: Europium-154 (GEA) . . . . . . . . B B-49

B2-75 Tank 241-T-105 Analytical Results: Europium-155 (GEA) . . . . . . . . . B-49

B2-76 Tank 241-T-105 Analytical Results: Potassium-40 (GEA) . . . . . . . . B B-50

B2-77 Tank 241-T-105 Analytical Results: Ruthenium-103 (GEA) . . . . . . . B B-50

B2-78 Tank 241-T-105 Analytical Results: Ruthenium/Rhodium-106 (GEA) . . . . B-51

B2-79 Tank 241-T-105 Analytical Results: Thorium-228 (GEA) . . . . . . . . . B-51

B2-80 Tank 241-T-105 Analytical Results: Carbon-14 (Liq Scin) . . . . . . . . B-52

B2-81 Tank 241-T-105 Analytical Results: Tritium (Liq Scin.) . . . . . . . . B-52

B2-82 Tank 241-T-105 Analytical Results: Technetium-99 (Liq Scin.) . . . . . . . B-52

B2-83 Tank 241-T-105 Analytical Results: Weight Percent Solids (Percent Solids) . . B-53

B2-84 Tank 241-T-105 Analytical Results: Weight Percent Centrifuged Solids (Physical Properties) $\ldots \ldots \ldots \ldots \ldots \ldots \ldots \ldots \ldots \ldots \ldots \ldots$

B2-85 Tank 241-T-105 Analytical Results: Weight Percent Residual Solids (Percent Solids) $\ldots \ldots \ldots \ldots \ldots \ldots \ldots$. . . . . . . . . . 


\section{LIST OF TABLES (Continued)}

B2-86a Tank 241-T-105 Analytical Results: Density (Physical Properties) . . . . . . B-54

B2-86b Tank 241-T-105 Analytical Results: Density (Physical Properties) . . . . . . B-54

B2-87 Tank 241-T-105 Analytical Results: Centrifuged Supernate Density (Physical Properties) $\ldots \ldots \ldots \ldots \ldots \ldots \ldots \ldots \ldots \ldots \ldots \ldots$

B2-88 Tank 241-T-105 Analytical Results: Centrifuged Solids Density (Physical Properties) $\ldots \ldots \ldots \ldots \ldots \ldots \ldots \ldots \ldots \ldots \ldots$. . . . . . . . . . .

B2-89 Tank 241-T-105 Analytical Results: Specific Gravity (SpG) . . . . . . . B-55

B2-90 Tank 241-T-105 Analytical Results: Volume Percent Settled Solids (Physical Properties) $\ldots \ldots \ldots \ldots \ldots \ldots \ldots \ldots \ldots \ldots \ldots$. . . . . . . . . . .

B2-91 Tank 241-T-105 Analytical Results: Volume Percent Centrifuged Solids (Physical Properties) $\ldots \ldots \ldots \ldots \ldots \ldots \ldots \ldots \ldots \ldots$. . . . . . . . . .

B2-92 Tank 241-T-105 Analytical Results: Total Dissolved Solids (Percent Solids) . B-56 B2-93 Tank 241-T-105 Analytical Results: Consistency Factor (Physical Properties) . B-57 B2-94 Tank 241-T-105 Analytical Results: Flow Behavior Index (Physical Properties) $\ldots \ldots \ldots \ldots \ldots \ldots \ldots \ldots \ldots$. . . . . . . . . . .

B2-95 Tank 241-T-105 Analytical Results: Yield Point (Physical Properties) . . . . B-57 B2-96 Tank 241-T-105 Analytical Results: Exothermic Results (DSC) . . . . . . . B-58 B2-97 Tank 241-T-105 Analytical Results: Percent Water (TGA) . . . . . . . . B-58 B2-98 Analysis of Sample T-4937 from Tank 241-T-105 (Collected in 1974) . . . . B-59

B3-1 Total Alpha Activity Comparison $\ldots \ldots \ldots \ldots \ldots \ldots \ldots \ldots$ B-62

B3-2 Total Beta Activity Comparison $\ldots \ldots \ldots \ldots \ldots \ldots \ldots \ldots \ldots$ B-63

B3-3 Cation Mass and Charge Data $\ldots \ldots \ldots \ldots \ldots \ldots \ldots \ldots \ldots$ B-65

B3-4 Anion Mass and Charge Data $\ldots \ldots \ldots \ldots \ldots \ldots \ldots \ldots$ B-66

B3-5 Mass Balance Totals $\ldots \ldots \ldots \ldots \ldots \ldots \ldots \ldots \ldots \ldots$ B-66 


\section{LIST OF TABLES (Continued)}

B3-6 Concentration Estimate Statistics (Units in $\mu \mathrm{g} / \mathrm{g}$ Except Radionuclides $[\mu \mathrm{Ci} / \mathrm{g}]) \ldots \ldots \ldots \ldots \ldots \ldots \ldots$. . . . . . . . . . . . . .

D2-1 Sample- and Historical Tank Content-Based Inventory Estimates for Nonradioactive Components in Tank 241-T-105 . . . . . . . . . . . D-4

D2-2 Sample- and Historical Tank Content-Based Inventory Estimates for Radioactive Components in Tank 241-T-105 . . . . . . . . . . . . D-6

D3-1 Technical Flowsheet and Los Alamos National Laboratory Defined Waste Streams . . . . . . . . . . . . . . . . . D-9

D3-2 Concentration Factors and Partitioning Factors for 1C, 2C,

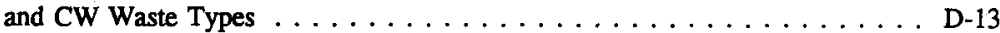

D3-3 Comparison of Selected Component Inventory Estimates for Tank 241-T-105 Waste

D4-1 Best-Basis Inventory Estimates for Nonradioactive Components in Tank 241-T-105 (September 30, 1996)

D4-2 Sample-Based Best-Basis Inventory Estimates for Radioactive Components for Tank 241-T-105 (All Curie Values Decayed to January 1, 1994) . . . . . . . D-22 
HNF-SD-WM-ER-369 Rev. 1

This page intentionally left blank. 
HNF-SD-WM-ER-369 Rev. 1

\section{LIST OF TERMS}

\begin{tabular}{|c|c|}
\hline${ }^{\circ} \mathrm{C}$ & degrees Celsius \\
\hline $1 \mathrm{C}$ & first cycle decontamination waste \\
\hline $2 \mathrm{C}$ & second cycle decontamination waste \\
\hline$\mu \mathrm{Ci} / \mathrm{g}$ & microcuries per gram \\
\hline$\mu \mathrm{Ci} / \mathrm{gal}$ & microcuries per gallon \\
\hline$\mu \mathrm{Ci} / \mathrm{mL}$ & microcuries per milliliter \\
\hline$\mu \mathrm{g} / \mathrm{g}$ & micrograms per gram \\
\hline$\mu \mathrm{m}$ & micrometer \\
\hline ASTM & American Society for Testing and Materials \\
\hline BL & B Plant low-level waste \\
\hline $\mathrm{Btu} / \mathrm{hr}$ & British thermal units per hour \\
\hline $\mathrm{cal} / \mathrm{g}$ & calories per gram \\
\hline CF & concentration factor \\
\hline $\mathrm{Ci}$ & curies \\
\hline $\mathrm{Ci} / \mathrm{L}$ & curies per liter \\
\hline $\mathrm{CI}$ & confidence interval \\
\hline $\mathrm{cm}$ & centimeters \\
\hline $\mathrm{c} / \mathrm{s}$ & counts per second \\
\hline CRW1 & coating waste from the dissolution of aluminum fuel \\
\hline CVAA & cold vapor atomic absorption \\
\hline $\mathrm{CW}$ & $\mathrm{BiPO}_{4}$ process aluminum cladding waste \\
\hline DOE & U.S. Department of Energy \\
\hline DQO & data quality objective \\
\hline DSC & differential scanning calorimetry \\
\hline DW & decontamination waste \\
\hline $\mathrm{EB}$ & evaporator bottoms \\
\hline $\mathrm{ft}$ & feet \\
\hline g & grams \\
\hline$g / L$ & grams per liter \\
\hline $\mathrm{g} / \mathrm{mL}$ & grams per millititer \\
\hline GEA & gamma energy analysis \\
\hline HDW & hanford defined waste \\
\hline HTCE & historical tank content estimate \\
\hline IC & ion chromatography \\
\hline ICP & inductively coupled plasma spectroscopy \\
\hline in. & inches \\
\hline IX & ion exchange waste \\
\hline $\mathrm{J} / \mathrm{g}$ & joules per gram \\
\hline $\mathrm{kg}$ & kilograms \\
\hline $\mathrm{kg} / \mathrm{L}$ & kilograms per liter \\
\hline
\end{tabular}




\section{LIST OF TERMS (Continued)}

\begin{tabular}{|c|c|}
\hline kgal & kilogallons \\
\hline $\mathrm{kL}$ & kiloliters \\
\hline kW & kilowatts \\
\hline L & liters \\
\hline LANL & Los Alamos National Laboratory \\
\hline LFL & lower flammability limit \\
\hline LI & lower limit \\
\hline $\mathrm{m}$ & meters \\
\hline$\underline{\mathbf{M}}$ & moles per liter \\
\hline $\mathrm{mm}$ & millimeters \\
\hline MT & metric ton \\
\hline PF & partitioning factor \\
\hline PHMC & Project Hanford Management Contractor \\
\hline ppm & parts per million \\
\hline $\mathrm{QC}$ & quality control \\
\hline RCW & REDOX process aluminum cladding waste \\
\hline RPD & relative percent difference \\
\hline TCR & tank characterization report \\
\hline TGA & thermogravimetric analysis \\
\hline TIC & total inorganic carbon \\
\hline TLM & tank layer model \\
\hline TOC & total organic carbon \\
\hline TWRS & Tank Waste Remediation System \\
\hline UL & upper limit \\
\hline W & watts \\
\hline WSTRS & Waste Status and Transaction Record Summary \\
\hline WTR & flush water \\
\hline wt \% & weight percent \\
\hline
\end{tabular}




\subsection{INTRODUCTION}

One major function of the Tank Waste Remediation System (TWRS) is to characterize wastes in support of waste management and disposal activities at the Hanford Site. Analytical data from sampling and analysis, along with other available information about a tank, are compiled and maintained in a tank characterization report (TCR). This report and its appendices serve as the TCR for single-shell tank 241-T-105. The objectives of this report are: 1) to use characterization data in response to technical issues associated with tank 241-T-105 waste, and 2) to provide a standard characterization of this waste in terms of a best-basis inventory estimate. Section 2.0 summarizes the response to technical issues, Section 3.0 shows the best-basis inventory estimate, and Section 4.0 makes recommendations regarding safety status and additional sampling. Supporting data and information are contained in the appendices. This report also supports the requirements of Hanford Federal Facility Agreement and Consent Order (Ecology et al. 1996), Milestone M-44-05.

\subsection{SCOPE}

The characterization information in this report originated from sample analyses and known existing (historical) sources. The most recent sampling of tank 241-T-105 (March and May 1993) predates current data quality objectives (DQOs). An investigation of the technical issues from the currently applicable DQOs was made using the data from the 1993 sampling events. Historical information for tank 241-T-105 included surveillance information, records pertaining to waste transfers and tank operations, and expected tank contents derived from a process knowledge model. This information is in Appendix A.

Appendix B summarizes the recent sampling events (see Table 1-1), sample data obtained prior to 1989, and the sampling results. The sampling and analysis of the 1993 core samples were performed in accordance with Bell (1993), and the results were originally reported in Giamberardini (1993) and Kocher (1994). Appendix C provides information on statistical analysis and numerical manipulation of data used in issue resolution. Appendix D contains the evaluation to establish the best basis for the inventory estimate and the statistical analysis performed for this evaluation. Appendix $\mathrm{E}$ is a bibliography that resulted from an in-depth literature search of all known information sources applicable to tank 241-T-105 and its respective waste types. A majority of the reports listed in Appendix E can be found in the Tank Characterization Resource Center. 
Table 1-1. Summary of Recent Sampling.

\begin{tabular}{|c|c|c|c|c|c|}
\hline $6 \%, n, 1 \%, \%$ & 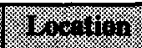 & 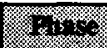 & 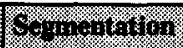 & 19003401 & 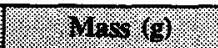 \\
\hline \multirow{2}{*}{$\begin{array}{l}\text { Core } 53 \\
(3 / 19 / 93)\end{array}$} & \multirow[t]{2}{*}{ Riser 8} & Solid & Segment 1 & $18 \%$ solid & Solid $=29.81$ \\
\hline & & $\begin{array}{l}\text { Liquid/ } \\
\text { solid }\end{array}$ & Segment 2 & $\begin{array}{l}56 \% \text { liquid; } \\
<3 \% \text { solid }\end{array}$ & Liquid $=97.6$ \\
\hline \multirow[t]{2}{*}{$\begin{array}{l}\text { Core 54 } \\
(3 / 24 / 93)\end{array}$} & \multirow[t]{2}{*}{ Riser 2} & $\begin{array}{l}\text { Liquid/ } \\
\text { solid }\end{array}$ & Segment 1 & $\begin{array}{l}5 \% \text { liquid; } \\
31 \% \text { solid }\end{array}$ & $\begin{array}{l}\text { Solid = } 116.8 \\
\text { Liquid }=13.8\end{array}$ \\
\hline & & Liquid & Segment 2 & $91 \%$ liquid $^{2}$ & Liquid $^{2}=164.53$ \\
\hline \multirow{2}{*}{$\begin{array}{l}\text { Core } 57 \\
(5 / 28 / 93)\end{array}$} & \multirow[t]{2}{*}{ Riser 5} & Solid & Segment 1 & $8 \%$ solid & Solids $=16.4$ \\
\hline & & Solid & Segment 2 & $8 \%$ solid & Solids $=16$ \\
\hline
\end{tabular}

Notes:

'Dates are in the $\mathrm{mm} / \mathrm{dd} / \mathrm{yy}$ format.

${ }^{2}$ Most likely water

\subsection{TANK BACKGROUND}

Tank 241-T-105 is located in the 200 West Area T Farm on the Hanford Site. It is the second tank in a three-tank cascade series connecting tank 241-T-104 upstream and to tank 241-T-106 downstream. The tank went into service in 1946, receiving second cycle decontamination (2C) waste from the bismuth phosphate process (Brevick et al. 1996). In 1948, tank 241-T-105 began receiving first cycle decontamination (1C) waste, also from the bismuth phosphate process. During its operational life, liquids from the tank were discharged to the cribs, to various tanks, and to the 242-T Evaporator. Other waste types were received by the tank, including coating waste, B Plant low-level waste (BL), and ionexchange (IX) waste. However, only $2 \mathrm{C}$ and $1 \mathrm{C}$ wastes are predicted to comprise the solids currently in the tank (Agnew et al. 1996). The tank was removed from service in 1976 and interim stabilized in 1987. Intrusion prevention was completed in 1988.

Table 1-2 describes tank 241-T-105. The tank has an operating capacity of 2,010 kL (530 kgal) and contains an estimated $371 \mathrm{~kL}$ (98 kgal) of noncomplexed waste (Hanlon 1996). The tank is not on the Watch List (Public Law 101-510). 


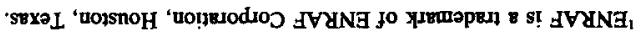

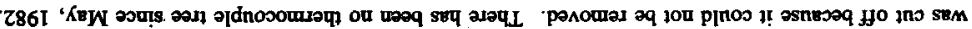

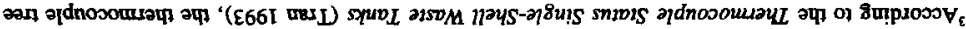

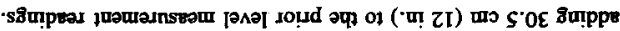

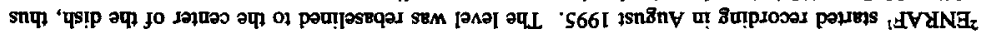

(966I) चо्षष्म,

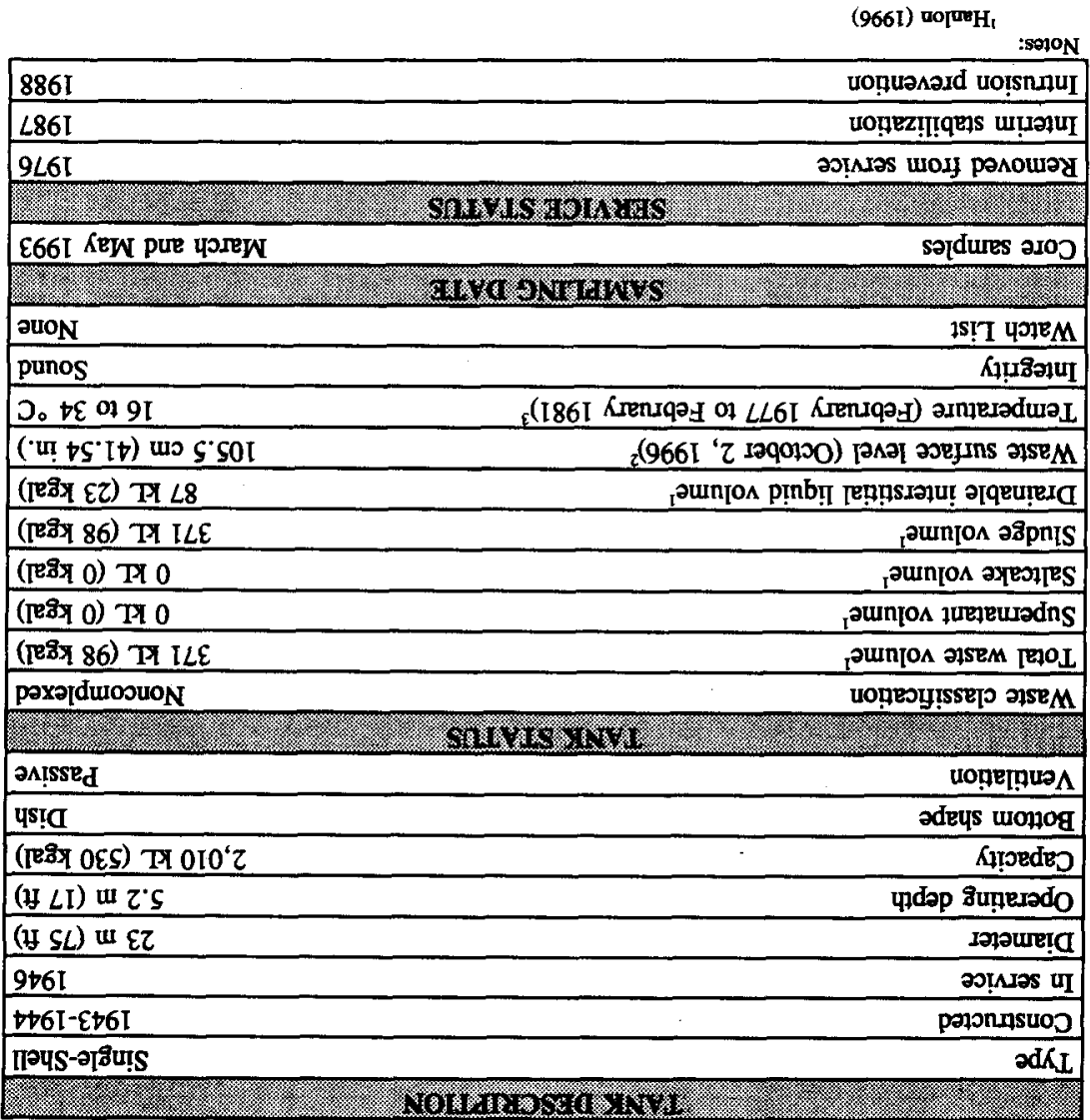

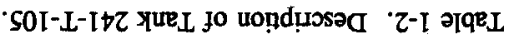


HNF-SD-WM-ER-369 Rev. 1

This page intentionally left blank. 


\subsection{RESPONSE TO TECHNICAL ISSUES}

Two technical issues have been identified for tank 241-T-105:

- Safety Screening: Does the waste pose or contribute to any recognized potential safety problems?

- Vapor Screening: Is there a potential for worker hazards associated with toxicity of constituents in any fugitive vapor emissions from the tank?

The safety screening DQO (Dukelow et al. 1995) provides the sampling requirements and the types of analyses used to address the safety screening issue. The most recent sampling of tank 241-T-105 occurred before the existence of DQOs. However, an effort has been made to address the safety screening DQO requirements using the 1993 core sampling data and available historical information. The response to the technical issue is detailed in the following sections. See Appendix B for sample and analysis data for tank 241-T-105.

Except for sniff tests conducted according to safety screening requirements, sampling for the vapor screening issue has not occurred to determine the lower flammability limit (LFL) of vapors in the headspace. Consequently, the vapor screening issue is not addressed further in this report. Sampling to address toxic vapors is currently scheduled for May, 1998. This report will be updated to include vapor screening results after tests are completed.

\subsection{SAFETY SCREENING}

The data needed to screen the waste in tank 241-T-105 for potential safety problems are documented in the safety screening DQO (Dukelow et al. 1995). These potential safety problems are exothermic conditions in the waste, flammable gases in the waste and/or tank headspace, and criticality conditions in the waste. Each condition is addressed separately. Because tank 241-T-105 is not a Watch List tank, the safety screening DQO is the only safety-related DQO currently applicable to the tank.

In addition to analytical requirements, the safety screening DQO specifies sampling conditions which must be met for a proper safety assessment. Full vertical profiles of the waste are required from two risers separated radially to the maximum extent possible. Complete vertical profiles were not obtained because sample recovery was poor. Therefore, samples did not satisfy the safety screening requirement. 


\subsubsection{Exothermic Conditions (Energetics)}

The first requirement outlined in the safety screening DQO (Dukelow et al. 1995) is to ensure there are not enough exothermic constituents (organic or ferrocyanide) in tank 241-T-105 to cause a safety hazard. The safety screening DQO required that the waste sample profile be tested for energetics every $24 \mathrm{~cm}(9.5 \mathrm{in}$.) to determine whether the energetics exceed the safety threshold limit. The threshold limit for energetics is $480 \mathrm{~J} / \mathrm{g}$ on a dry weight basis.

Differential scanning calorimetry (DSC) analyses yielded slight exotherms in samples originating from cores 53 and 57; however, exotherms were not observed in core 54 samples. The maximum exotherm was $334 \mathrm{~J} / \mathrm{g}$ on a dry weight basis. This is below the safety screening criterion of $480 \mathrm{~J} / \mathrm{g}$ (Dukelow et al. 1995).

The segments were not subdivided into halves because of the low recovery; therefore, the requirement of testing energetics for every $24 \mathrm{~cm}(9.5 \mathrm{in}$.) of the sample profile was not met.

Based on historical process transfer records, there is no evidence that any exothermic agent should exist in this waste. According to Agnew et al. (1996), no fuels are expected in the waste types $(2 \mathrm{C} 1$ and $1 \mathrm{C} 2)$ predicted to compose the waste in the tank. Although not predicted by Agnew et al. to be present in the tank, other waste types received by the tank (coating waste) did contain small quantities of organics.

\subsubsection{Flammable Gas}

A vapor measurement, taken using procedures WHC-IP-0030 IH 1.4 and WHC-IP-0030 IH 2.1 on May 9, 1996, indicated that no flammable gases were present (0 percent of the LFL).

\subsubsection{Criticality}

The safety threshold limit is $1 \mathrm{~g}{ }^{239} \mathrm{Pu}$ per liter of waste. Assuming that all alpha is from ${ }^{239} \mathrm{Pu}$ and using the measured solids density of $1.64 \mathrm{~g} / \mathrm{mL}$ (based on core 57 analyses), $1 \mathrm{~g} / \mathrm{L}$ of ${ }^{239} \mathrm{Pu}$ is equivalent to $37.5 \mu \mathrm{Ci} / \mathrm{g}$ of alpha activity. For the liquids, a limit of

$61.5 \mu \mathrm{Ci} / \mathrm{mL}$ was computed. The activity of total alpha in all samples was well below these limits. The highest activity measured was $0.823 \mu \mathrm{Ci} / \mathrm{g}$ for the solids and $0.0285 \mu \mathrm{Ci} / \mathrm{mL}$ for the liquids. The DQO also requires the calculation of a 95 percent confidence interval on each sample. For tank 241-T-105, this computation was made only on the tank solids (fusion) mean. The upper limit of the confidence interval was $2.84 \mu \mathrm{Ci} / \mathrm{g}$ which is well below the safety threshold. 


\subsection{OTHER TECHNICAL ISSUES}

A factor in assessing tank safety is the heat generation and temperature of the waste. Heat is generated in the tanks from radioactive decay. An estimate of the tank heat load based on 1993 radionuclide analyses gives a value of $1,370 \mathrm{~W}(4,670 \mathrm{Btu} / \mathrm{hr})$. To provide the most conservative heat load estimate possible, detection limits for the nondetected analytes were included. Table 2-1 shows the heat load estimate. A second heat load estimate of $13.9 \mathrm{~W}$ (47.5 Btu/hr), based on process history, was available from Agnew et al. (1996). A third estimate based on tank headspace temperatures was $1,461 \mathrm{~W}(4,988 \mathrm{Btu} / \mathrm{hr})$ (Kummerer 1994). All heat load estimates are well below the limit of 11,700 W $(40,000 \mathrm{Btu} / \mathrm{hr})$ that separates high- and low-heat load tanks (Smith 1986).

Table 2-1. Tank 241-T-105 Projected Heat Load.

\begin{tabular}{|l|l|l|}
\hline${ }^{241} \mathrm{Am}$ & 240 & 7.87 \\
\hline${ }^{125} \mathrm{Sb}$ & 404 & 1.35 \\
\hline${ }^{144} \mathrm{Ce} / \mathrm{Pr}$ & $<1,060$ & $<3.28$ \\
\hline${ }^{134} \mathrm{Cs}$ & $<64.4$ & $<0.657$ \\
\hline${ }^{137} \mathrm{Cs}$ & 33,800 & 160 \\
\hline${ }^{60} \mathrm{Co}$ & 1,280 & 19.7 \\
\hline${ }^{154} \mathrm{Eu}$ & 448 & 4.05 \\
\hline${ }^{155} \mathrm{Eu}$ & 1,280 & 0.792 \\
\hline${ }^{238} \mathrm{Pu}$ & $<0.149$ & 0.00486 \\
\hline${ }^{239} / 240 \mathrm{Pu}$ & 84.5 & 2.58 \\
\hline${ }^{103} \mathrm{Ru}$ & $<99.7$ & $<0.350$ \\
\hline${ }^{106} \mathrm{Ru} / \mathrm{Rh}$ & $<1,300$ & $<12.5$ \\
\hline${ }^{90} \mathrm{Sr}$ & $1.71 \mathrm{E}+05$ & 1,150 \\
\hline${ }^{99} \mathrm{Tc}$ & 226 & 0.113 \\
\hline${ }^{228} \mathrm{Th}$ & $<163$ & $<5.23$ \\
\hline $\mathrm{Total}$ & $2.10 \mathrm{E}+05$ & 1,370 \\
\hline & & \\
\hline
\end{tabular}




\subsection{SUMMARY}

The safety screening DQO was not met for tank 241-T-105. Because sample recovery was poor, complete vertical profiles were not obtained, and DSC analyses were not performed on a half-segment basis. Safety decision threshold limits were met for the samples obtained.

Table 2-2. Summary of Safety Screening Results.

\begin{tabular}{|l|l|l|}
\hline \multirow{3}{*}{$\begin{array}{l}\text { Safety } \\
\text { screening }\end{array}$} & Energetics & $\begin{array}{l}\text { Exotherms were observed, but the results were below } \\
\text { the } 480 \mathrm{~J} / \mathrm{g} \text { threshold on a dry weight basis. }\end{array}$ \\
\cline { 2 - 3 } & Flammable gas & $\begin{array}{l}\text { The vapor measurement was reported at 0 percent of } \\
\text { the LFL (combustible gas meter). }\end{array}$ \\
\cline { 2 - 3 } & $\begin{array}{l}\text { All analytical results were well below the total alpha } \\
\text { activity limits. }\end{array}$ \\
\hline
\end{tabular}




\subsection{BEST-BASIS INVENTORY ESTIMATE}

Information about the chemical, radiological, and/or physical properties of tank wastes is used to perform safety analyses, engineering evaluations, and risk assessments associated with waste management activities, as well as regulatory issues. These activities include overseeing tank farm operations and identifying, monitoring, and resolving safety issues associated with these operations and with the tank wastes. Disposal activities involve designing equipment, processes, and facilities for retrieving wastes and processing them into a form that is suitable for long-term storage. Chemical and radiological inventory information are generally derived using three approaches: (1) component inventories are estimated using the results of sample analyses, (2) component inventories are predicted using the Hanford Defined Waste (HDW) model based on process knowledge and historical information, or (3) a tank-specific process estimate is made based on process flowsheets, reactor fuel data, essential material usage, and other operating data. The information derived from these different approaches is often inconsistent.

An effort is underway to provide waste inventory estimates that will serve as the standard characterization for the various waste management activities (Hodgson and LeClair 1996). As part of this effort, an evaluation of available chemical information for tank 241-T-105 was performed. The information included the following:

- Data from two core composite samples from tank 241-T-105 collected in 1993 (DiCenso et al. 1994).

- Data from three tanks that contain the same waste types as tank 241-T-105: first cycle decontamination [1C] waste, second cycle decontamination [2C] waste, and aluminum cladding waste [CW]) all from the $\mathrm{BiPO}_{4}$ process. The three tanks with $1 \mathrm{C}, 2 \mathrm{C}$, and $\mathrm{CW}$ waste are tanks 241-T-104, 241-B-111, and 241-U-204, respectively (see Figure 3-1).

- Inventory estimates generated by the HDW model (Agnew et al. 1996).

The evaluation results support using a predicted inventory based primarily on analytical results for tanks 241-T-104, 241-B-111, and 241-U-204 as the basis for the best-estimate inventory for tank 241-T-105 for the following reasons:

- Waste transactions based on Anderson (1990) for tank 241-T-105 show significant quantities of $\mathrm{CW}$ solids as well as waste solids from the first and second contamination cycles of the $\mathrm{BiPO}_{4}$ process. The HDW model (Agnew et al. 1996) predicts only 1C and 2C waste layers in the tank. Although the analytical data based on the 1993 core samples from tank 241-T-105 are considered poor because solids recovery was low. The analytical results indicate that waste from this sample contained primarily $\mathrm{CW}$. 
HNF-SD-WM-ER-369 Rev. 1

Figure 3-1. Schematic of 1C, 2C and CW Waste Contributions for Tank 241-T-105 Best Basis Inventory Estimates, and Representative Tanks for Each Waste Type.

BASIS TANK

241-U-204

241-T-104

241-B-111
WASTE TYPE

(VOL)

CW

$79 \mathrm{~kL}$ (21 kgal)

$1 \mathrm{C} / \mathrm{CW}$

$76 \mathrm{~kL}$ (20 kgal)

2C

$216 \mathrm{~kL}$ (57 kgal) 
- Because waste recovery for the two core samples from tank 241-T-105 was incomplete, it is unlikely that the sample-based inventory represents the entire tank. However, radionuclide distribution in the samples appears to represent the tank, based on heat load estimates.

- The solubility data in Agnew et al. (1996) for several chemical components are not consistent with the analytical data for tanks that contain only $1 \mathrm{C}$ and $2 \mathrm{C}$ waste (tanks 241-T-104 and 241-B-111, respectively).

Because of the limited sample recovery, the sample data for tank 241-T-105 are not considered representative of the entire tank contents. As a result, the analytical-based inventories for tanks 241-T-104, 241-B-111, and 241-U-204 were used to derive the best-basis inventory of chemical components that were added to tank 241-T-105 from process flowsheet additions. The analytical results from tanks 241-T-104, 241-B-111, and 241-U-204, which contain only $1 \mathrm{C}, 2 \mathrm{C}$, and $\mathrm{CW}$, respectively, agree well with predicted inventories for these tanks based on process flowsheets and waste fill history. Assessments have shown that the analytical-based compositions for these tanks can be extrapolated to the same waste types in other tanks, particularly where the tanks are in a cascade arrangement. The assumption regarding representativeness of the tank samples must be considered speculative at this time with resolution provided by possible future resampling of this tank.

Inventories for components not added from the process flowsheets are based on core samples from tank 241-T-105. All radionuclide inventories are based on the sample analysis of tank 241-T-105. Radionuclide curie values are decayed to January 1, 1994.

Tables 3-1 and 3-2 show best-basis inventory estimates for tank 241-T-105. The quality of the estimate for chemical and radionuclide components is considered low because the inventories are extrapolated from data from other tanks (241-T-105, 241-B-111, and 241-U-204), or they are based on the sample results from tank 241-T-105, which are considered biased. 
HNF-SD-WM-ER-369 Rev. 1

Table 3-1. Best-Basis Inventory Estimates for Nonradioactive

Components in Tank 241-T-105 (September 30, 1996). (2 Sheets)

\begin{tabular}{|c|c|c|c|}
\hline 2 & 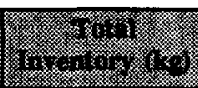 & 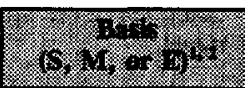 & 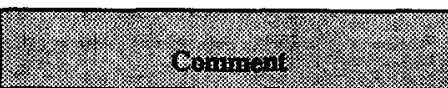 \\
\hline Al & 17,000 & $\mathrm{E}$ & \\
\hline $\mathbf{B i}$ & 7,500 & E & \\
\hline $\mathrm{Ca}$ & 2,200 & $S$ & \\
\hline$\overline{\mathrm{Cl}}$ & 240 & $S$ & Based on analysis of water leach only \\
\hline $\mathrm{CO}_{3}$ & 17,500 & $S$ & \\
\hline $\mathrm{Cr}$ & 360 & $\mathbf{E}$ & \\
\hline $\bar{F}$ & 1,200 & $\bar{E}$ & \\
\hline $\mathrm{Fe}$ & 8,600 & $\mathbf{E}$ & \\
\hline $\mathrm{Hg}$ & 1 & $\mathbf{M}$ & Poor sample basis \\
\hline$\overline{\mathbf{K}}$ & 190 & $S$ & \\
\hline $\mathrm{La}$ & 0 & $\mathbf{M}$ & Poor sample basis \\
\hline Mn & 7,000 & $S$ & Likely to be much lower \\
\hline $\mathrm{Na}$ & 38,000 & E & Based on analysis of leach water only \\
\hline $\mathrm{Ni}$ & 28 & $\bar{M}$ & Poor sample basis \\
\hline $\mathrm{NO}_{2}$ & 4,000 & $\mathrm{E}$ & Based on analysis of leach water only \\
\hline $\mathrm{NO}_{3}$ & 31,000 & $\mathbf{E}$ & Based on analysis of leach water only \\
\hline$\overline{\mathrm{OH}}$ & 13,000 & $M$ & Poor sample basis \\
\hline $\mathrm{Pb}$ & 280 & $S$ & \\
\hline $\mathrm{P}$ as $\mathrm{PO}_{4}$ & 20,000 & $\mathrm{E}$ & \\
\hline $\mathrm{Si}$ & 4,300 & $E$ & \\
\hline $\mathrm{S}$ as $\mathrm{SO}_{4}$ & 5,800 & $E$ & \\
\hline $\mathrm{Sr}$ & 85 & $S$ & \\
\hline
\end{tabular}


HNF-SD-WM-ER-369 Rev. 1

Table 3-1. Best-Basis Inventory Estimates for Nonradioactive

Components in Tank 241-T-105 (September 30, 1996). (2 Sheets)

\begin{tabular}{|l|l|l|l|l|}
\hline & & $(1,0)$ & \\
\hline TOC & 0 & $\mathrm{M}$ & Poor sample basis \\
\hline $\mathrm{U}_{\text {Toul }}$ & 1,000 & $\mathrm{E}$ & \\
\hline $\mathrm{Zr}$ & 21 & $\mathrm{E}$ & \\
\hline
\end{tabular}

Notes:

'S = Sample-based, $\mathrm{M}=$ Hanford Defined Waste model-based, $\mathrm{E}=$ Engineering assessment-based from tanks 241-T-104, 241-B-111, and 241-U-204

${ }^{2}$ Sample-based inventories were based on partial cores with poor recovery (see Appendix B). 
Table 3-2. Sample-Based Best-Basis Inventory Estimates for Radioactive Components for Tank 241-T-105 (All Curie Values Decayed to January 1, 1994).

\begin{tabular}{|l|l|l|l|}
\hline & & & \\
\hline & 7.6 & $\mathrm{~S}$ & \\
\hline${ }^{3} \mathrm{H}$ & 0.61 & $\mathrm{~S}$ & \\
\hline${ }^{14} \mathrm{C}$ & 23 & $\mathrm{~S}$ & $\begin{array}{l}\text { Based on analysis of water leach } \\
\text { only }\end{array}$ \\
\hline${ }^{60} \mathrm{Co}$ & $1.7 \mathrm{E}+05$ & $\mathrm{~S}$ & \\
\hline${ }^{90} \mathrm{Sr}$ & $1.7 \mathrm{E}+05$ & $\mathrm{~S}$ & \\
\hline${ }^{90} \mathrm{Y}$ & 230 & $\mathrm{~S}$ & \\
\hline${ }^{95} \mathrm{Tc}$ & 400 & $\mathrm{~S}$ & $\begin{array}{l}\text { Based on analysis of water leach } \\
\text { only }\end{array}$ \\
\hline${ }^{125} \mathrm{Sb}$ & 30,000 & $\mathrm{~S}$ & \\
\hline${ }^{137} \mathrm{Cs}$ & 1,100 & $\mathrm{~S}$ & \\
\hline${ }^{154} \mathrm{Eu}$ & 1,300 & $\mathrm{~S}$ & \\
\hline${ }^{155} \mathrm{Eu}$ & 84 & $\mathrm{~S}$ & \\
\hline${ }^{2391240} \mathrm{Pu}$ & 520 & $\mathrm{~S}$ & \\
\hline${ }^{241} \mathrm{Am}$ & & & \\
\hline
\end{tabular}

Notes:

'S = Sample-based, $\mathbf{M}=$ Hanford Defined Waste model-based, $\mathrm{E}=$ Engineering assessment-based ${ }^{2}$ Sample-based inventories were based on partial cores with poor recovery (see Appendix B). 


\subsection{RECOMMENDATIONS}

All analytical results were well within the notification limits of the safety screening DQO. However, because of the poor sample recoveries, the recovered waste probably does not represent the overall tank waste. Therefore, the tank cannot yet be classified as "safe." The sampling and analysis activities performed for tank 241-T-105 have partially met the requirements of the applicable DQO documents. A characterization best-basis inventory was also developed for the tank contents.

Table 4-1 summarizes the status of the Project Hanford Management Contractor (PHMC) TWRS Program Office review and acceptance of the sampling and analysis results reported in this tank characterization report. All applicable DQOs are listed in column 1 of Table 4-1. Column 2 indicates by "yes" or "no" whether the requirements of the DQO were met by the sampling and analysis activities performed. Column 3 indicates concurrence and acceptance by the TWRS program responsible for the DQO that the sampling and analysis activities performed adequately meet the needs of the DQO. A "yes" or "no" indicates acceptance or disapproval of the sampling and analysis information presented in the TCR. If the results/information have not yet been reviewed, "N/R" is shown in column 3; if the results/information have been reviewed, but acceptance or disapproval has not been decided, "N/D" is shown.

Table 4-1. Acceptance of Tank 241-T-105 Sampling and Analysis.

\begin{tabular}{|c|c|c|}
\hline 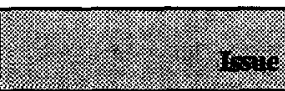 & $\frac{1}{20}$ & 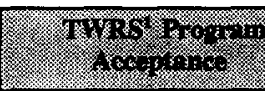 \\
\hline Safety Screening DQO & Yes & $\mathrm{N} / \mathrm{D}$ \\
\hline
\end{tabular}

Note:

'PHMC TWRS Program Office

Table 4-2 summarizes the status of this PHMC TWRS Program Office review and acceptance of the evaluations and other characterization information contained in this report. The evaluations specifically outlined in this report are the best-basis inventory evaluation and the evaluation to determine whether the tank is safe, conditionally safe, or unsafe. Column 1 lists the different evaluations performed in this report. Columns 2 and three are in the same format as Table 4-1. The manner in which concurrence and acceptance are summarized is the same as that in Table 4-1. 
HNF-SD-WM-ER-369 Rev. 1

Table 4-2. Acceptance of Evaluation of Characterization Data and Information for Tank 241-T-105.

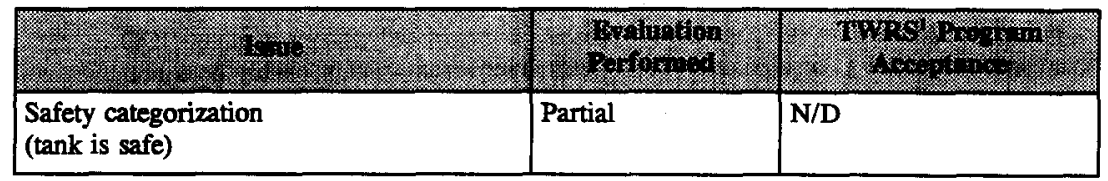

Note:

'PHMC TWRS Program Office 


\subsection{REFERENCES}

Agnew, S. F., J. Boyer, R. Corbin, T. Duran, J. FitzPatrick, K. Jurgensen, T. Ortiz, and B. Young, 1996, Hanford Tank Chemical and Radionuclide Inventories: HDW Model Rev. 3, LA-UR-96-858, Los Alamos National Laboratory, Los Alamos, New Mexico.

Anderson, J. D., 1990, A History of the 200 Area Farms, WHC-MR-0132, Westinghouse Hanford Company, Richland, Washington.

Bell, K. E., 1993, Tank Waste Remediation System Tank Waste Characterization Plan, WHC-SD-WM-PLN-047, Rev. 1, Westinghouse Hanford Company, Richland, Washington.

Brevick, C. H., L. A. Gaddis, and E. D. Johnson, 1996, Historical Tank Content Estimate for The Northwest Quadrant of the Hanford 200 West Area, WHC-SD-WM-ER-351, Westinghouse Hanford Company, Richland, Washington.

DiCenso, A. T., L. C. Amato, J. D. Franklin, G. L. Nuttall, K. W. Johnson,

B. C. Simpson, 1994, Tank Characterization Report for Single-Shell Tank 241-T-105, WHC-SD-WM-ER-369, Rev. 0, Westinghouse Hanford Company, Richland, Washington.

Dukelow, G. T., J. W. Hunt, H. Babad, and J. E. Meacham, 1995, Tank Safety Screening Data Quality Objective, WHC-SD-WM-SP-004, Rev. 2, Westinghouse Hanford Company, Richland, Washington.

Ecology, EPA, and DOE, 1996. Hanford Federal Facility Agreement and Consent Order, Washington State Department of Ecology, U.S. Environmental Protection Agency, and U.S. Department of Energy, Olympia, Washington.

Giamberardini, K. K., 1993, 222-S Laboratories Single-Shell Tank Waste Characterization, Tank-T-105 Core 57 Data Package, WHC-SD-WM-DP-040, Rev. 0, Westinghouse Hanford Company, Richland, Washington.

Hanlon, B. L., 1996. Waste Tank Summary Report for Month Ending August 31, 1996. WHC-EP-0182-101, Westinghouse Hanford Company, Richland, Washington.

Hodgson K. M. and M. D. LeClair, 1996, Work Plan for Defining A Standard Inventory Estimate for Wastes Stored in Hanford Site Underground Tanks, WHC-SD-WM-WP-311, Rev. 1, Westinghouse Hanford Company, Richland, Washington. 
Kocher, K. L., 1994, Single-Shell Tank Waste Characterization, Tank T-105, Cores 53 and 54, WHC-SD-WM-DP-047, Rev. 0-B, Westinghouse Hanford Company, Richland, Washington.

Kummerer, M., 1994, Topical Report on Heat Removal Characteristics of Waste Storage Tanks, WHC-SD-WM-SARR-010, Rev, 0, Westinghouse Hanford Company, Richland, Washington.

Public Law 101-510, 1990, "Safety Measures for Waste Tanks at Hanford Nuclear Reservation," Section 3137 of National Defense Authorization Act for Fiscal Year 1991.

Smith, D. A., 1986, Single-Shell Tank Isolation Safety Analysis Report, WHC-SD-WM-SAR-006, Rev. 2, Westinghouse Hanford Company, Richland, Washington.

Tran, T. T., 1993, Thermocouple Starus Single-Shell and Double-Shell Waste Tanks, WHC-SD-WM-TI-533, Rev. 0, Westinghouse hanford company, Richland, Washington. 
HNF-SD-WM-ER-369 Rev. 1

APPENDIX A

HISTORICAL TANK INFORMATION 
HNF-SD-WM-ER-369 Rev, 1

This page intentionally left blank. 


\section{APPENDIX A \\ HISTORICAL TANK INFORMATION}

Appendix A describes tank 241-T-105 based on historical information. For this report, historical information includes any information about the fill history, waste types, surveillance, or modeling data about the tank. This information is often useful for supporting or challenging conclusions based on sampling and analysis.

This appendix contains the following information:

- Section A1: Current status of the tank, including the current waste levels and the stabilization and isolation status of the tank.

- Section A2: Information about the tank design.

- Section A3: Process knowledge about the tank, that is, the waste transfer history and the estimated contents of the tank based on modeling data.

- Section A4: Surveillance data for tank 241-T-105, including surface-level readings, temperatures, and a description of the waste surface based on photographs.

- Section A5: Appendix A references.

Historical sampling results are included in Appendix B.

\section{A1.0 CURRENT TANK STATUS}

As of August 31, 1996, tank 241-T-105 contained an estimated $371 \mathrm{~kL}$ (98 kgal) of non-complexed waste. This waste is entirely composed of sludge, with an estimated $87 \mathrm{~kL}$ (23 kgal) of drainable interstitial liquid (Hanlon 1996). The solid volume was determined by surface-level measurements, and the liquid volume was determined by photographic evaluation (Hanlon 1996). Table A1-1 shows the volumes of the waste phases found in the tank. Temperature data are not available after February, 1981 because no thermocouple tree is in this tank currently. Section 4.0 discusses waste levels and tank temperatures further. Tank 241-T-105 is listed as a low heat load tank (Hanlon 1996), and is passively vented to the atmosphere through a breather filter (Bergmann 1991). With the exception of temperature readings, monitoring systems are currently in compliance with established standards (Hanlon 1996). 
Tank 241-T-105 is not a Watch List tank (Public Law 101-510). The integrity of the tank is sound. Tank 241-T-105 was removed from service in 1976; interim stabilization (1987) and intrusion prevention (1988) were performed later (Hanlon 1996).

Table A1-1. Tank 241-T-105 Contents Status Summary. ${ }^{1}$

\begin{tabular}{|l|l|}
\hline Total waste & $371 \mathrm{~kL}(98 \mathrm{kgal})$ \\
\hline Supernatant & $0 \mathrm{~kL}(0 \mathrm{kgal})$ \\
\hline Sludge & $371 \mathrm{~kL}(98 \mathrm{kgal})$ \\
\hline Saltcake & $0 \mathrm{~kL}(0 \mathrm{kgal})$ \\
\hline Drainable interstitial liquid & $87 \mathrm{~kL}(23 \mathrm{kgal})$ \\
\hline Drainable liquid remaining & $87 \mathrm{~kL}(23 \mathrm{kgal})$ \\
\hline Pumpable liquid remaining & $64 \mathrm{~kL}(17 \mathrm{kgal})$ \\
\hline
\end{tabular}

Note:

'Hanlon (1996)

\section{A2.0 TANK DESIGN AND BACKGROUND}

The T Tank Farm was built between 1943 and 1944 and was one of the first four tank farms constructed at the Hanford Site. It is the northernmost tank farm in the 200 West Area. T Farm was designed for nonboiling waste with a maximum fluid temperature of $104{ }^{\circ} \mathrm{C}$. A typical T Farm tank contains 9 to 11 risers, ranging in size from $10 \mathrm{~cm}$ (4 in.) to $1.1 \mathrm{~m}$ (42 in.) in diameter, that provide surface-level access to the underground tank. Generally, there is one riser through the center of the tank dome and four or five each on opposite sides of the dome. These single-shell tanks are constructed of $30 \mathrm{~cm}(1 \mathrm{ft})$-thick reinforced concrete with a $6.4 \mathrm{~mm}$ ( $0.25 \mathrm{in}$.) mild carbon steel liner (ASTM A283 Grade C) on the bottom and sides and a $38 \mathrm{~cm}(1.25 \mathrm{ft})$ thick domed concrete top. The tanks have a dished

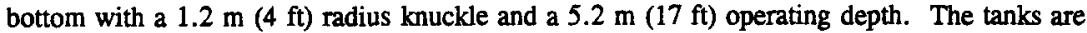
set on a reinforced concrete foundation. Tank 241-T-105 has a diameter of $23 \mathrm{~m} \mathrm{(75} \mathrm{ft)} \mathrm{and}$ a capacity of $2,010 \mathrm{~kL}$ (530 kgal) (Brevick et al. 1995b). 
The tank and foundation were waterproofed by a coating of tar covered by a three-ply, asphalt impregnated, waterproofing fabric. The waterproofing was protected by welded wire reinforced gunite. Two coats of primer were sprayed on all exposed interior surfaces. The tank ceiling dome was covered with three applications of magnesium zincfluorosilicate wash. Lead flashing was used to protect the joint where the steel liner meets the concrete dome. Asbestos gaskets were used to seal the risers in the tank dome. The tank was covered with

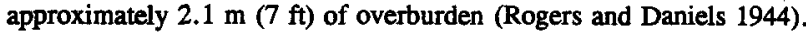

Tank 241-T-105 is the second tank in a "cascade" that connects tanks 241-T-104 and 241-T-106. The tanks are connected by a $7.6 \mathrm{~cm}$ (3 in.) cascade line. A cascade was a system whereby several tanks were connected in series by pipes. The pipes were located at the top of the tanks' working depths. Waste was added to the first tank in a cascade and flowed to the next tank without overfilling the first tank. By using a cascade, fewer connections needed to be made during waste handling operations. This method reduced waste handling requirements, personnel exposure, and the chance of a loss of tank integrity from waste overflow. Another advantage of using the cascades was to clarify the waste. Heavier solids and insoluble constituents would precipitate primarily in the first tank (tank 241-T-104), and the clarified liquids would flow through the cascade to the other tanks (241-T-105 and 241-T-106). This practice led to rapid filling of the first tank with solids and enabled the clarified liquid from the tanks in the cascade to be discharged to cribs.

Figure A2-1 is a plan view of the riser configuration. The figure shows that tank 241-T-105 has four process inlet nozzles, one cascade inlet, and one cascade outlet. Table A2-1 lists tank 241-T-105 risers and shows their sizes and general use.

Figure A2-2 shows a tank cross section and the approximate waste level and a schematic of the tank equipment. Tank $241-\mathrm{T}-105$ has nine risers. Risers $2,3,5,6,7$, and 8 are tentatively available for sampling (Lipnicki 1996). Risers 2, 3, 6, and 7 are all $30 \mathrm{~cm}$ (12 in.) in diameter. Risers 5 and 8 are $10 \mathrm{~cm}$ (4 in.) in diameter. Risers 2 and 3 are approximately 40 degrees counterclockwise from the inlet, and risers $5,6,7$, and 8 are approximately 70 degrees clockwise from the inlet. 
HNF-SD-WM-ER-369 Rev. 1

Figure A2-1. Riser Configuration for Tank 241-T-105.

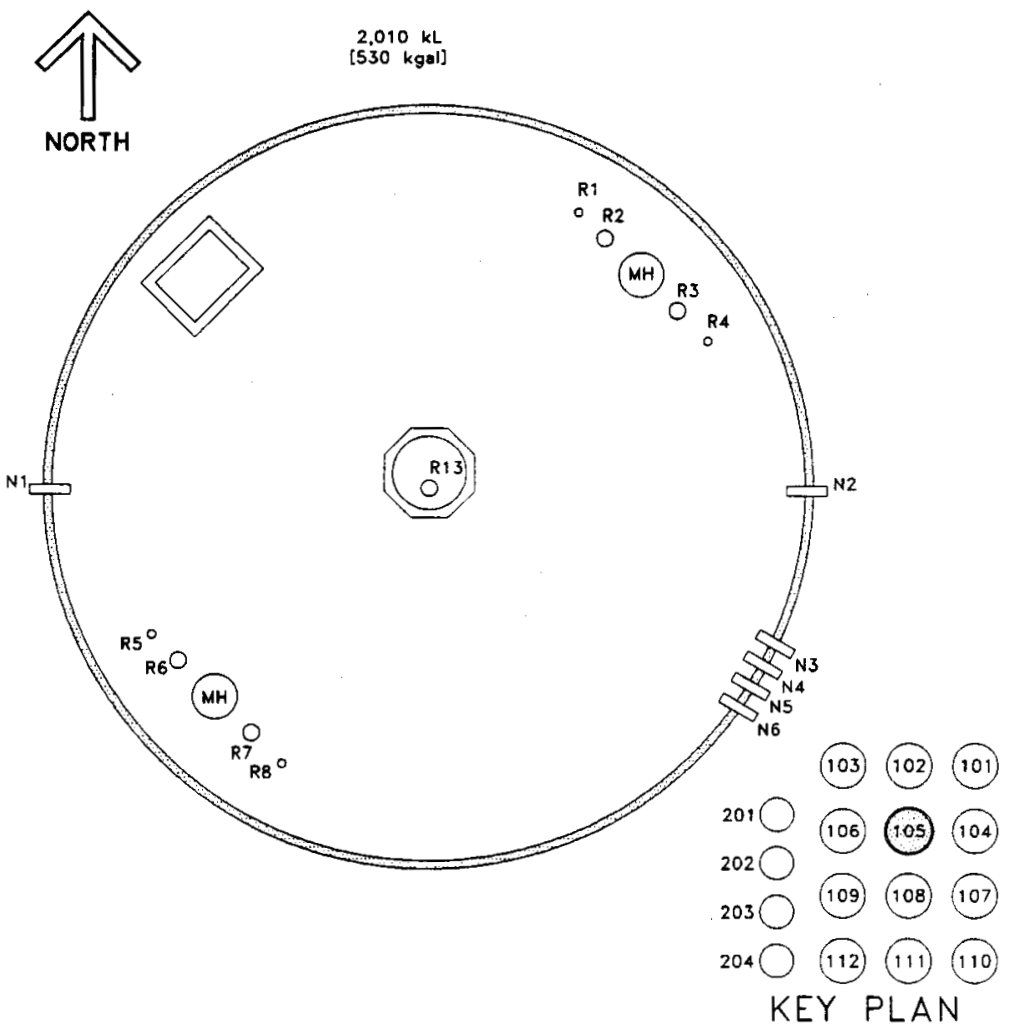


HNF-SD-WM-ER-369 Rev. 1

Table A2-1. Tank 241-T-105 Risers. 1,2,3,4,5

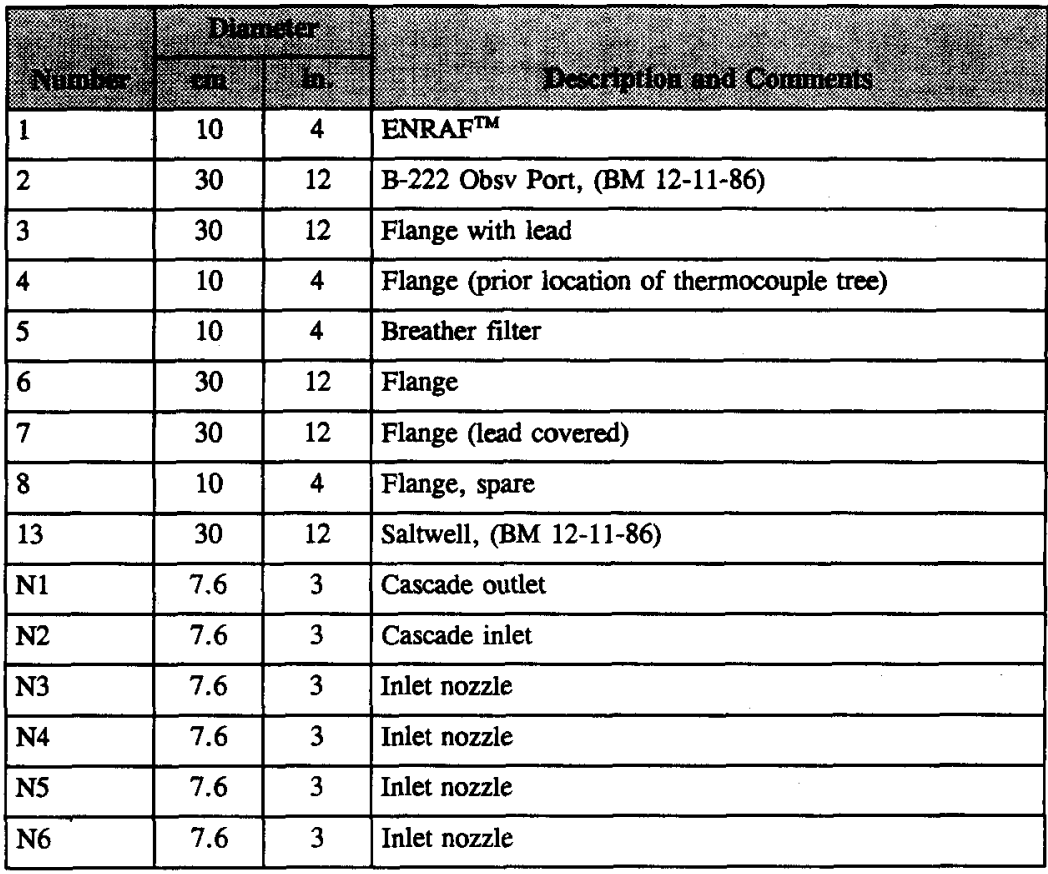

Notes:

'Alstad (1993)

${ }^{2}$ Tran (1993)

${ }^{3}$ Vitro Engineering Corporation (1988)

The parentheses include engineering change notices prior to 1995.

'If there was a discrepancy between the documents and the drawing, the drawing took precedence. 
HNF-SD-WM-ER-369 Rev. 1

Figure A2-2. Tank 241-T-105 Cross-Section and Schematic.

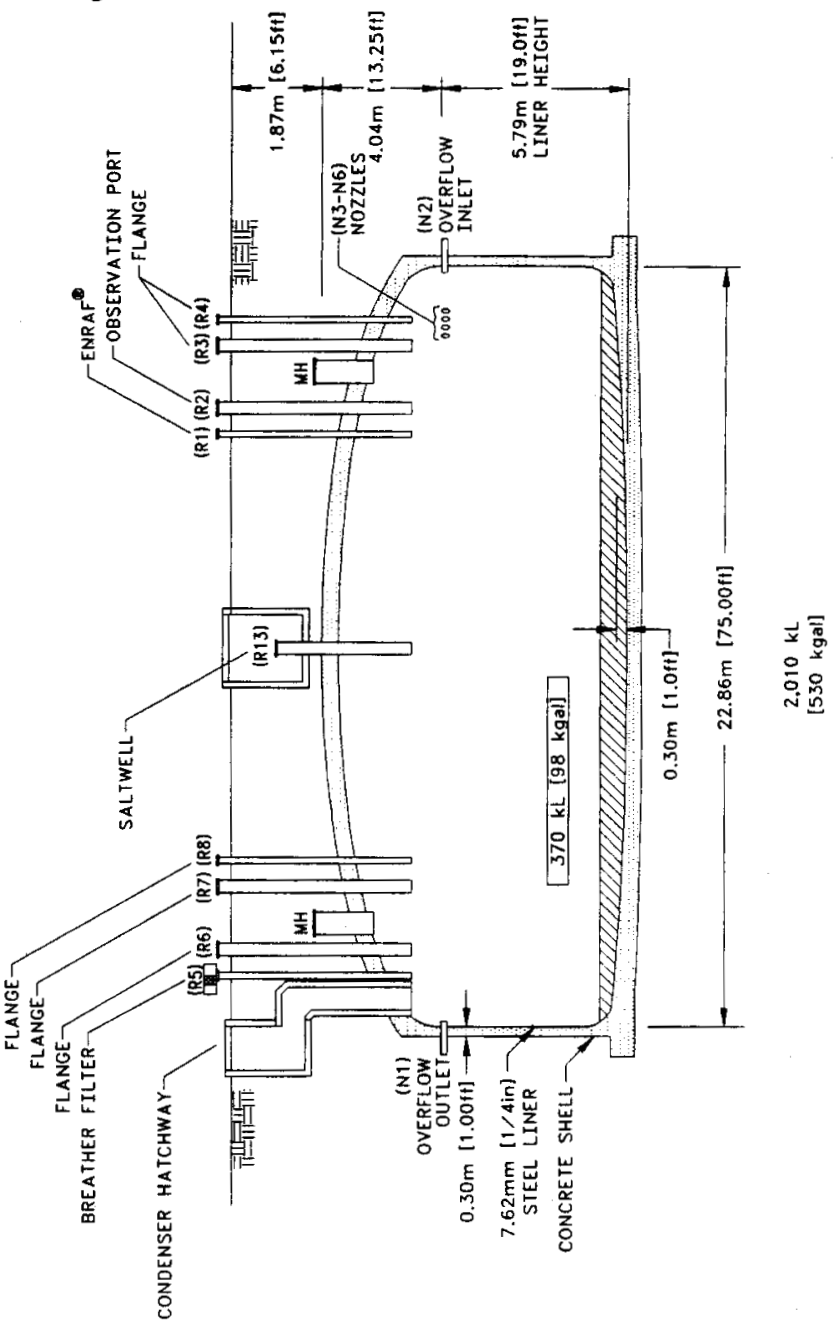




\section{A3.0 PROCESS KNOWLEDGE}

The sections below: 1) provide information about the transfer history of tank 241-T-105, 2) describe the process wastes that made up the transfers, and 3) give an estimate of the current tank contents based on transfer history.

\section{A3.1 WASTE TRANSFER HISTORY}

Table A3-1 summarizes the waste transfer history of tank 241-T-105. The first waste type introduced into tank 241-T-105 was second cycle (2C) waste in 1946 (Agnew et al. 1996b). This waste consisted of effluent remaining after precipitation of plutonium product in the second decontamination cycle of the $\mathrm{BiPO}_{4}$ process at $\mathrm{T}$ Plant. The $2 \mathrm{C}$ waste filled the tank and cascaded to tank 241-T-106 from 1947 to the first quarter of 1948 . Because tank 241-T-105 received waste directly from T-plant, $2 \mathrm{C}$ solids are expected to have been deposited in the lower portion of the tank. In the second quarter of 1948 , much of the $2 \mathrm{C}$ supernate in tank $241-\mathrm{T}-105$ was sent to the T-107 crib.

From the second quarter of 1948 to the first quarter of 1949 , first cycle (1C) waste cascaded into tank 241-T-105 from tank 241-T-104. Waste cascaded from 241-T-105 to 241-T-106 during this same period. Produced in the $\mathrm{BiPO}_{4}$ process at $\mathrm{T}$ plant, $1 \mathrm{C}$ waste consisted of by products co-precipitated from a plutonium-containing solution. Coating waste from the removal of aluminum fuel element cladding was also added; it comprised about 24 percent of the waste stream. The $1 \mathrm{C}$ waste is characterized by a relatively high concentration of bismuth and aluminum. During the second quarter of 1951, the waste was transferred from tank 241-T-105 to tanks 241-TX-117 and 241-TX-118. The 1C waste cascaded from tank 241-T-104 to 241-T-105 from the fourth quarter of 1951 to the third quarter of 1954. In 1954, the supernatant in tank 241-T-105 was pumped out and sent to a crib. Supernatant waste was also sent to tank 241-TX-118 the fourth quarter of 1954 . The cascade system was not used after 1954 .

The tank began receiving cladding waste at the beginning of 1955 and was full by the end of 1956. Agnew et al. (1996a) defines the origin of the cladding waste from the REDOX process (RCW). Whereas Anderson (1990) targets the cladding waste as CW from the $\mathrm{BiPO}_{4}$ process. Further evaluation of waste transaction records in Agnew (1996b) tends to indicate $\mathrm{BiPO}_{4}$ was added, rather than $\mathrm{RCW}$ waste. Flush water was also added to the waste during 1956.

Tank 241-T-105 received supernatant from tank 241-S-107 in 1965. From 1967 to 1968 , supernate was transferred to tank 241-TX-118 as feed to the 242-T Evaporator. In 1967 , Hanford laboratory operations waste was transferred to tank 241-T-105. This dilute waste was generated by laboratories in the 300 Area. In 1968 and 1969, tank 241-T-105 received 
decontamination waste (DW), a wash solution from equipment decontamination efforts at T-Plant. It is composed of a dilute sodium nitrite solution, averaging $0.024 \mathrm{M}$ sodium nitrite.

Tank 241-T-105 received transfers from other single-shell tanks of liquid waste mixtures containing B Plant low-level (BL) and ion exchange (IX) wastes in 1973. Supernate, consisting of most of the tank's volume, was transferred to tank 241-T-106 in the same year. B Plant low-level waste originated from the fractionization plant. Ion exchange waste was a product of the cesium recovery process at B Plant.

In 1974, supernate waste was transferred to tank 241-S-110. Small supernate transfers from saltwell pumping were made from tanks 241-T-101 and 241-AY-102 in 1976 and 1984, respectively. Table A3-1 shows the estimated cumulative volume of each waste type received and transferred by tank 241-T-105.

\section{A3.2 HISTORICAL ESTIMATION OF TANK CONTENTS}

This section provides an estimate of the contents of tank $241-\mathrm{T}-105$ based on historical transfer data. The historical data used for the estimate are the Waste Status and Transaction Record Summary (WSTRS) (Agnew et al. 1996b), the Hanford Defined Waste (HDW) (Agnew et al. 1996a) list, and the tank layer model (TLM). The HDW and TLM are found in the Hanford Tank Chemical and Radionuclide Inventories: HDW Model Rev. 3 (Agnew et al. 1996a). The WSTRS is a compilation of available waste transfer and volume status data. The HDW is a list of the assumed typical compositions for 50 separate wastes types. In some cases, the available data are incomplete, reducing the usefulness of the transfer data and the modeling results derived from it. The TLM takes the WSTRS data, models the waste deposition processes, and, using data from the HDW, derives the primary waste layers in the tank. Therefore, these model predictions can only be considered estimates that require further evaluation using analytical data.

Based on Agnew et al. (1996a), tank 241-T-105 contains a bottom layer of $270 \mathrm{~kL}$ (72 kgal) of $2 \mathrm{Cl}$ waste and a top layer of $98 \mathrm{~kL}(26 \mathrm{kgal})$ of $1 \mathrm{C} 2$ waste. The $2 \mathrm{Cl}$ waste type is $2 \mathrm{C}$ waste produced from 1944 to 1949 . The $1 \mathrm{C} 2$ waste type is $1 \mathrm{C}$ waste generated from 1950 to 1956 . Figure A3-1 is a graphical representation of the estimated waste type and volume for the tank layers. Both the $2 \mathrm{C} 1$ and $1 \mathrm{C} 2$ waste types are predicted to contain greater than one weight percent of sodium, hydroxide, nitrate, and phosphate, and between 1 and 0.1 weight percent of sulfate, calcium, carbonate, silicate and fluoride. Bismuth and iron are predicted above 1 weight percent for $2 \mathrm{Cl}$ waste, and aluminum is predicted at greater than 1 weight percent for $1 \mathrm{C} 2$ waste. Table A3-2 shows the historical estimate of the expected tank waste constituents and their concentrations. 
HNF-SD-WM-ER-369 Rev. 1

Table A3-1. Tank 241-T-105 Major Transfers ${ }^{1,2}$.

\begin{tabular}{|c|c|c|c|c|c|}
\hline \multirow{2}{*}{ (3) } & \multirow{2}{*}{ fla } & \multirow[b]{2}{*}{ 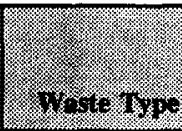 } & \multirow[b]{2}{*}{ 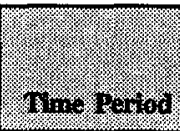 } & \multicolumn{2}{|c|}{ 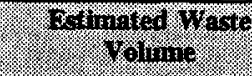 } \\
\hline & & & & 14 & 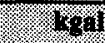 \\
\hline $\begin{array}{l}\text { Direct from } \\
\text { T-plant }\end{array}$ & -- & $2 \mathrm{Cl}$ & $1946-1948$ & $+4,012$ & $+1,060$ \\
\hline$\cdots$ & $241-T-106$ & --- & $\begin{array}{l}1946-1949 \\
1951-1954\end{array}$ & $-8,346$ & $-2,205$ \\
\hline$\cdots$ & Crib T-107 & Supernate & 1948 & -1321 & -349 \\
\hline 241-T-104 & -- & $1 \mathrm{C}$ & $\begin{array}{l}1948-1949 \\
1951-1954\end{array}$ & $+10,955$ & $+2,894$ \\
\hline-- & 241-TX-117 & Supernate & 1951 & -863 & -228 \\
\hline-- & 241-TX-118 & Supernate & $\begin{array}{l}1951,1954, \\
1967 \text { and } 1968\end{array}$ & -6568 & $-1,735$ \\
\hline --- & Crib & Supernate & 1954 & -1313 & -347 \\
\hline REDOX & -- & $\mathrm{CW}^{3}$ & $1955-1956$ & +980 & +259 \\
\hline Flush Water & --- & WTR & $1955-1956$ & +314 & +83 \\
\hline 241-S-107 & -- & Supernate & 1965 & +83 & +22 \\
\hline $\begin{array}{l}300 \text { Area } \\
\text { Laboratories }\end{array}$ & $-\cdots$ & Lab waste & 1967 & $+1,499$ & +396 \\
\hline T Plant & --- & DW & $1968-1969$ & $+1,230$ & +325 \\
\hline BX-104 &.- & BL, IX & $1972-1973$ & $+1,435$ & +379 \\
\hline 241-T-107 & --- & BL, IX & 1973 & $+1,711$ & +452 \\
\hline-- & $\begin{array}{l}241-\mathrm{T}-106, \\
\mathrm{~S}-110, \mathrm{~T}-101\end{array}$ & Supernate & 1973- 1975 & -3335 & -881 \\
\hline--- & AY-102 & Saltwell liquid & 1984 & -64 & -17 \\
\hline
\end{tabular}

Notes:

WTR $=$ flush water

'Agnew et al. (1996b)

${ }^{2}$ Because only major transfers are listed, the sum of these transfers will not equal the current tank waste volume.

${ }^{3}$ Anderson (1990) 
HNF-SD-WM-ER-369 Rev. 1

Figure A3-1. Tank Layer Model.

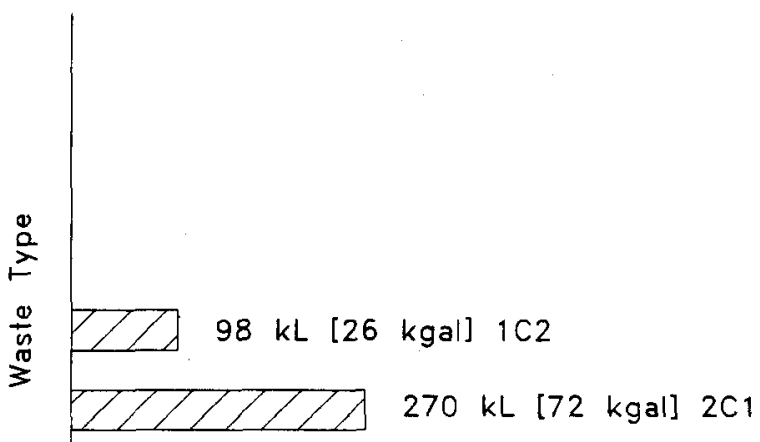

Waste Volume 
HNF-SD-WM-ER-369 Rev. 1

Table A3-2. Historical Tank Inventory Estimate. ${ }^{1,2}$ (2 sheets)

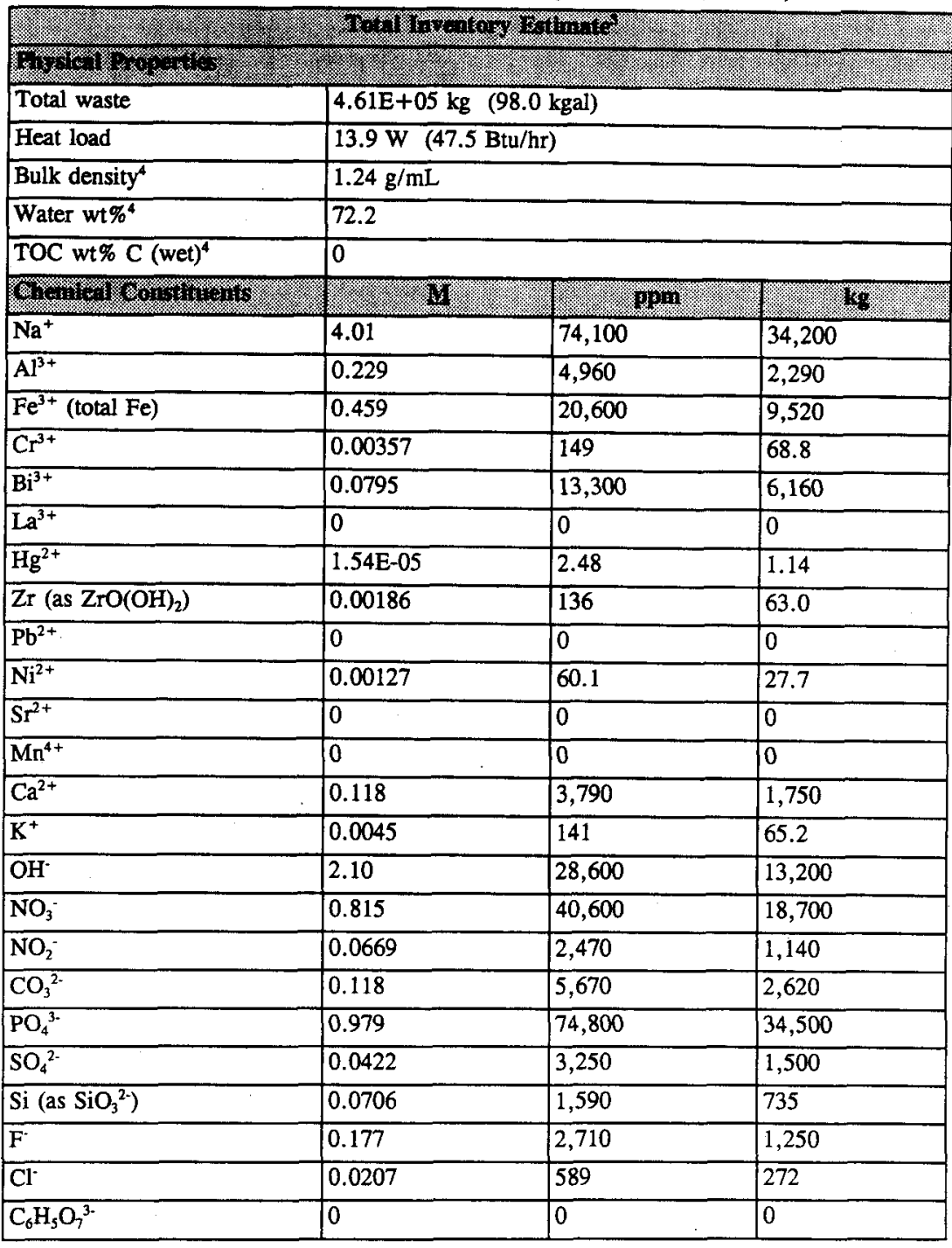


Table A3-2. Historical Tank Inventory Estimate. ${ }^{1,2}$ (2 sheets)

\begin{tabular}{|c|c|c|c|}
\hline 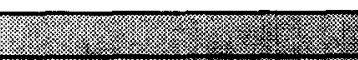 & 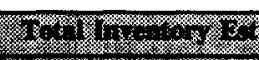 & mis & 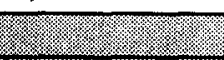 \\
\hline (6) & 1) & 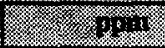 & (18) \\
\hline EDTA $^{4-}$ & 0 & 0 & 0 \\
\hline HEDTA $^{3-}$ & 0 & 0 & 0 \\
\hline glycolate & 0 & 0 & 0 \\
\hline acetate & 0 & 0 & 0 \\
\hline oxalate ${ }^{2-}$ & 0 & 0 & 0 \\
\hline DBP & 0 & 0 & 0 \\
\hline butanol & 0 & 0 & 0 \\
\hline $\mathrm{NH}_{3}$ & $1.47 \mathrm{E}-04$ & 2.00 & 0.924 \\
\hline $\mathrm{Fe}(\mathrm{CN})_{6}^{4-}$ & 0 & 0 & 0 \\
\hline 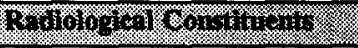 & (1) & 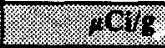 & 1) \\
\hline $\mathrm{Pu}$ & -- & 0.0133 & $0.102(\mathrm{~kg})$ \\
\hline$\overline{\mathrm{U}}$ & $2.25 \mathrm{E}-04(\mathrm{M})$ & $43.1(\mu \mathrm{g} / \mathrm{g})$ & $19.9(\mathrm{~kg})$ \\
\hline Cs & 0.0079 & 6.35 & 2930 \\
\hline $\mathrm{Sr}$ & $7.55 \mathrm{E}-05$ & 0.0607 & 28.0 \\
\hline
\end{tabular}

Notes:

wt $\%$ weight percent

'Agnew et al. (1996a)

${ }^{2}$ These predictions have not been validated and should be used with caution.

${ }^{3}$ Unknowns in tank solids inventory are assigned by the TLM.

This is the volume average for density, mass average water weight percent, and TOC weight percent Carbon.

\section{A4.0 SURVEILLANCE DATA}

Tank 241-T-105 surveillance consists of surface-level measurements, temperature monitoring, and dry well monitoring for radioactivity outside the tank. Surveillance data provide the basis for determining tank integrity. 
Liquid-level measurements can indicate if the tank has a major leak. Solid surface-level measurements indicate physical changes and consistency of the solid layers of a tank. Dry wells located around the tank perimeter may show increased radioactivity caused by leaks in the vicinity of the dry wells.

\section{A4.1 SURFACE-LEVEL READINGS}

An ENRAF surface-level gauge was installed in July 1995. Before this, surface-level readings were taken by Food Instrument Corporation in intrusion mode. Surface-level measurements are manually entered into the Computer Automated Surveillance System. Surface level data from 1991 to 1996 show a steady waste level. In January 1996, the location for surface level measurements was changed from the tank side wall to near the tank center. Figure A4-1 shows the level history data. The waste surface level on October 2 , 1996 , was $105.5 \mathrm{~cm}$ (41.54 in.).

\section{A4.2 INTERNAL TANK TEMPERATURES}

Historical temperature data from 1977 to 1981 ranged from $16^{\circ} \mathrm{C}$ to $34^{\circ} \mathrm{C}$ (see

Figure A4-2). The last available temperature reading for tank $241-\mathrm{T}-105$ was $23^{\circ} \mathrm{C}$ taken February 1981. The thermocouple tree was cut off in 1981 (Brevick et al. 1995b).

Tank 241-T-105 has not received waste since it was removed from service in 1976, but $64 \mathrm{~kL}$ (17 kgal) of supernatant waste has been removed. This may have affected the tank temperature. Also, historical temperatures may be higher than current temperatures because radiation-generated heat decreases as radioactive constituents decay over time. 
Figure A4-1. Tank 241-T-105 Level History.

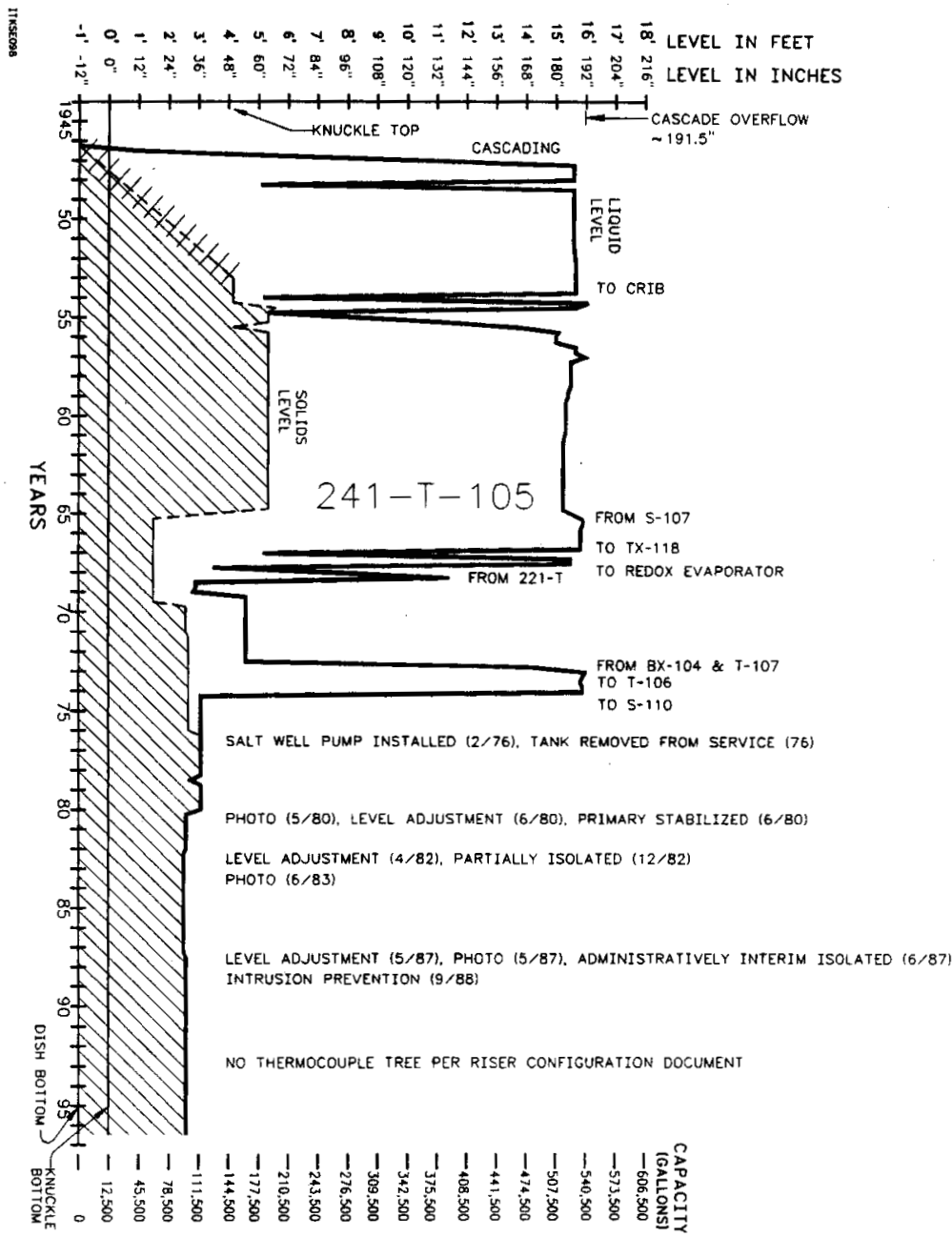


HNF-SD-WM-ER-369 Rev. 1

Figure A4-2. Tank 241-T-105 High Temperature Plot.

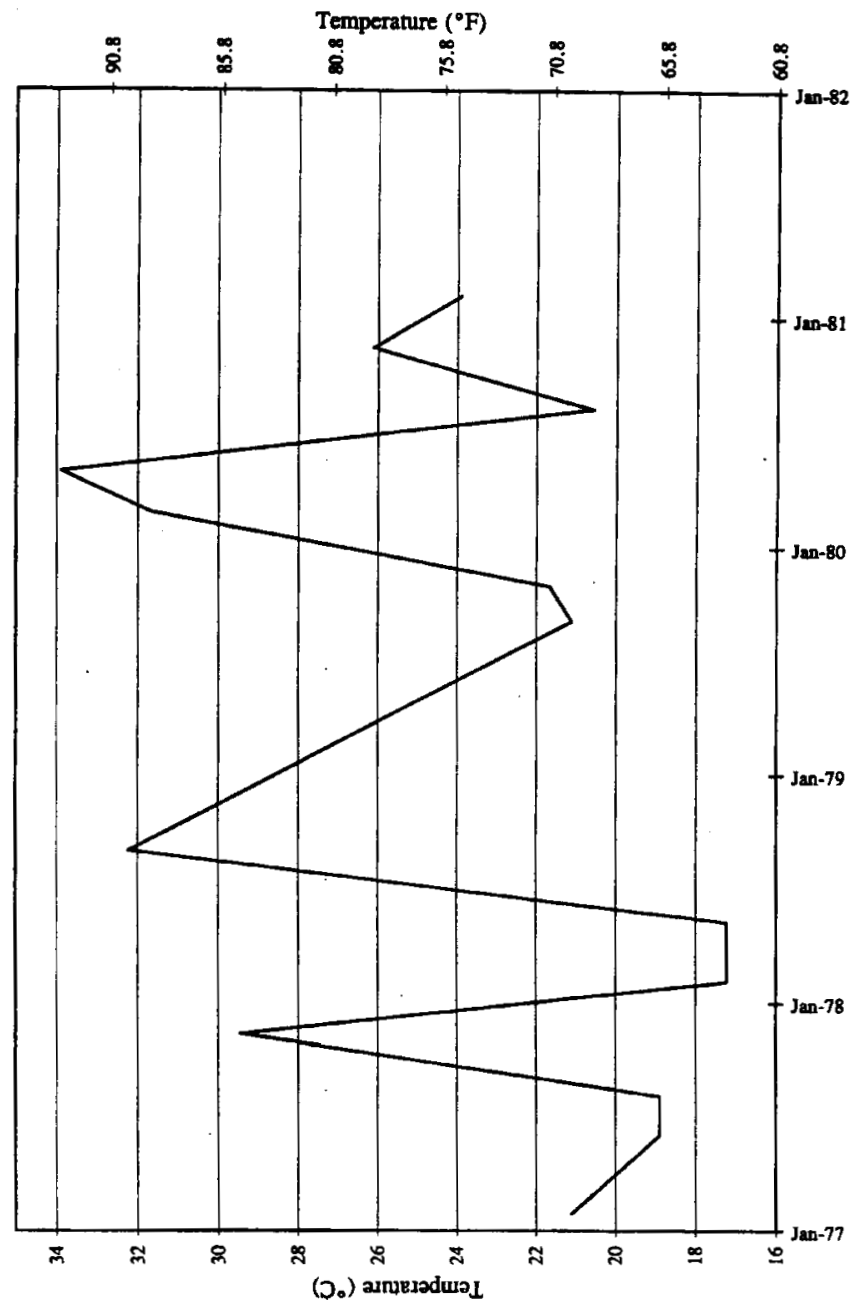




\section{A4.3 DRY WELL RADIOACTIVITY}

Two dry wells were drilled around tank 241-T-105 in 1973, and another dry well was drilled in 1975 . These dry wells have registered high radioactivity. The dry well closest to tank $241-\mathrm{T}-106$ had greater than $200 \mathrm{c} / \mathrm{s}$. The remaining two had greater than $50 \mathrm{c} / \mathrm{s}$ before 1990. The radioactivity has been attributed to an estimated $435 \mathrm{~kL}$ (115 kgal) leak from tank 241-T-106 (Welty 1988).

\section{A4.4 TANK 241-T-105 PHOTOGRAPHS}

The 1976 photographic montage of the inside of tank 241-T-105 shows a black, uneven surface, that appears to have a medium-brown colored material underneath. In part of the montage, a small amount of liquid appears to be on the waste surface. Some liquids have evaporated since 1987, but the photograph probably represents current tank contents. 


\section{A5.0 APPENDIX A REFERENCES}

Agnew, S. F., J. Boyer, R. A. Corbin, T. B. Duran, J. R. FitzPatrick, K. A. Jurgensen, T. P. Ortiz, and B. L. Young, 1996a, Hanford Tank Chemical and Radionuclide Inventories: HDW Model Rev. 3, LA-UR-96-858, Rev. 1, Los Alamos National Laboratory, Los Alamos, New Mexico.

Agnew, S. F., R. A. Corbin, T. B. Duran, K. A. Jurgensen, T. P. Ortiz, and B. L. Young, 1996b, Waste Status and Transaction Record Summary for the Northwest Quadrant of the Hanford 200 East Area, WHC-SD-WM-TI-669, Rev. 1, Westinghouse Hanford Company, Richland, Washington.

Alstad, A. T., 1993, Riser Configuration Document for Single-Shell Waste Tanks, WHC-SD-WM-RE-TI-053, Rev. 9, Westinghouse Hanford Company, Richland, Washington.

Anderson, J. D., 1990, A History of the 200 Area Tank Farms, WHC-MR-0132, Rev. 0, Westinghouse Hanford Company, Richland, Washington.

Bergmann, L. M., 1991, Single-Shell Tank Isolation Safety Analysis Report, WHC-SD-WM-SAR-006, Rev. 2, Westinghouse Hanford Company, Richland, Washington.

Brevick, C. H., L. A. Gaddis, and E. D. Johnson, 1995a, Historical Tank Content Estimate for The Northwest Quadrant of the Hanford 200 West Area, WHC-SD-WM-ER-351, Westinghouse Hanford Company, Richland, Washington.

Brevick, C. H., L. A. Gaddis, and W. W. Pickett, 1995b, Supporting Document for the Historical Tank Content Estimate for T Tank Farm - Volumes 1 and 2, WHC-SD-WM-ER-320, Rev. 0, Westinghouse Hanford Company, Richland, Washington.

Hanlon, B. M., 1996, Waste Tank Summary Report for Month Ending August 31, 1996, WHC-EP-0182-101, Westinghouse Hanford Company, Richland, Washington.

Lipnicki, J., 1996, Waste Tank Risers Available for Sampling, WHC-SD-WM-TI-710, Rev. 3, Westinghouse Hanford Company, Richland, Washington.

Public Law 101-510, 1990, "Safety Measures for Waste Tanks at Hanford Nuclear Reservation," Section 3137 of National Defense Authorization Act for Fiscal Year 1991. 
Rogers, R. D. and H. T. Daniels, 1944, Specifications for Construction of Composite Storage Tank Bldg. \#241 at Hanford Engineer Works, CVI-73550, E. I. Dupont de Nemours \& Co., Richland, Washington.

Swaney, S. L., 1994, Single-Shell Tank Stabilization Record, WHC-SD-RE-178, Rev. 4, Westinghouse Hanford Company, Richland, Washington.

Tran, T. T., 1993, Thermocouple Status Single Shell and Double Shell Waste Tanks, WHC-SD-WM-TI-553 Rev. 0, Westinghouse Hanford Company, Richland, Washington.

Vitro Engineering Corporation, 1988, Piping Waste Tank Isolation 241-T-105, H-2-73062, Rev. 4, Richland, Washington.

Welty, R. K., 1988, Waste Storage Tank Status and Leak Detection Criteria, WHC-SD-WM-TI-356, Vol. 2, Westinghouse Hanford Company, Richland, Washington. 
HNF-SD-WM-ER-369 Rev. 1

\section{APPENDIX B}

SAMPLING OF TANK 241-T-105

B-1 
HNF-SD-WM-ER-369 Rev. 1

This page intentionally left blank. 


\section{APPENDTX B}

\section{SAMPLING OF TANK 241-T-105}

Appendix B provides sampling and analysis information for each known sampling event for tank 241-T-105 and an assessment of the core sampling results.

- Section B1: Tank Sampling Overview

- Section B2: Analytical Results

- Section B3: Assessment of Characterization Results

- Section B4: References for Appendix B

Future sampling of tank 241-T-105 will be appended to the above list.

\section{B1.0 TANK SAMPLING OVERVIEW}

This section describes the March and May 1993 sampling and analysis events for tank 241-T-105. The sampling and analyses were performed in accordance with the Tank Waste Remediation System Tank Waste Characterization Plan, Rev. 1 (Bell 1993). The results of these analyses will support Tank Farm Operations and safety programs. It also will assist in the design of retrieval, pretreatment, and disposal systems and fulfill milestones contained in the Tri-Party Agreement (Bell 1993).

The 1993 sampling events predated current DQOs, so no DQOs were applicable. Further discussions of the sampling and analysis procedures are in the Tank Characterization Reference Guide (DeLorenzo et al. 1994). A 1974 sampling of the tank liquid is discussed in Section B1.4.

\section{B1.1 DESCRIPTION OF SAMPLING EVENTS}

Two push mode core samples were collected from tank 241-T-105 in 1993. Cores 53 and 54 were collected on March 19 and 23, respectively, from risers 8 and 2. The field blank was collected on March 22, 1993. These cores were transported to the Westinghouse Hanford Company 222-S Laboratory for chemical analyses. Portions of core 54 were sent to the Pacific Northwest National Laboratory (PNNL) 325 Laboratory. Core 57 samples were collected on May 28, 1993 from riser 5 to support the core sampling restart effort. Both segments were sent to the PNNL 325 Laboratory for physical tests. 
The core samples were obtained by a core sampling truck with sampling equipment mounted on a rotating platform. A drill string containing a stainless steel sampler was used to collect the waste. The sampler obtained a $48 \mathrm{~cm}$ (19 in.) long and $2.5 \mathrm{~cm}$ (1 in.) diameter segment of the waste. After the sampler was filled, it was extracted from the drill string and sealed within a stainless steel liner to trap any liquid which might leak from the sampler. The liner was inserted into a lead shielded shipping cask before being transferred to the laboratories. Chain-of-custody forms were completed for each segment.

Although not specified in the chain-of-custody forms or the sampling documentation, it is believed that water was used as a hydrostatic head fluid during sampling. The letter of instruction for prioritizing the analyses (Silvers and Sasaki 1993) mentions that "the liquid obtained from core 54 was clear and appeared to be the water used as a hydrostatic head fluid." No other discussion of the use of a hydrostatic head fluid was found.

\section{B1.2 SAMPLE HANDLING}

Core samples 53 and 54 were received by the 222-S Laboratory from March 22, 1993 to March 29, 1993 without preservation (no acidification or refrigeration). The 325 Laboratory received core 57 and aliquots from core 54 on June 14, 1993, without refrigeration or acidification. Each core consisted of two segments. The segments were a mixture of air, liquids, and solids. The following describes the contents of each core segment (Kocher 1994 and Giamberardini 1993).

\section{B1.2.1 Core 53}

Segment 1 - Solids comprised 18 percent, or $33.66 \mathrm{~mL}$, of the $187 \mathrm{~mL}$ volume of the sampler. The solids weighed $29.81 \mathrm{~g}$. The solids were brown, homogeneous, a muddy texture, and had no crust. No drainable liquid was recovered; however, $11.32 \mathrm{~g}$ of liner liquid, which drains from the sample as contamination into the sample liner or from head fluid, was obtained. Eighty-two percent of the sampler volume was occupied by air.

Segment 2 - Less than 3 percent of the $187 \mathrm{~mL}$ sampler volume was occupied by solid material. Fifty-six percent of the sample volume, or $104.72 \mathrm{~mL}$, was liquid. The remaining volume of the sampler was empty. Drainable liquid measuring $97.6 \mathrm{~g}$ and $11.24 \mathrm{~g}$ of liner liquid were collected. The volume of drainable liquid recovered was $85 \mathrm{~mL}$ because of the loss of approximately 10 to $20 \mathrm{~mL}$ from the sample tray. 


\section{B1.2.2 Core 54}

Segment 1 - The recovered material was predominantly solid, making up approximately 31 percent, or $57.97 \mathrm{~mL}$, of the $187 \mathrm{~mL}$ sample volume. The mass of the solids was $116.8 \mathrm{~g}$. The material was dark brown to white in appearance and had a smooth and wet texture. The segment was nonhomogeneous. Five percent, or $9.35 \mathrm{~mL}$, of the sampler volume was occupied by drainable liquid; this liquid weighed $13.8 \mathrm{~g}$. In addition, $0.8 \mathrm{~g}$ of liner liquid were recovered. The remaining 64 percent, or $119.68 \mathrm{~mL}$, of the sample volume was comprised of air.

Segment 2 - Ninety-one percent of the recovered sample, or $170 \mathrm{~mL}$, was comprised of drainable liquid. The net weight of the liquid was $164.53 \mathrm{~g}$. The remaining 9 percent of the sample volume was occupied by air. No solids were recovered. In addition to the drainable liquid, about $4.94 \mathrm{~g}$ of liner liquid were recovered.

\section{B1.2.3 Core 57}

Segment 1 - Dry solids of approximately $1.5 \mathrm{in}$. were extruded from the sampler. No drainable liquid was recovered, and no liner liquid was present. The breakdown of the sampler volume is as follows: 92 percent air, 0 percent liquid, and 8 percent solids $(16.4 \mathrm{~g})$. The solids were dark brown, cohesive, dry, and homogeneous. No subsampling was performed on the solids.

Segment 2 - Damp solids of approximately 1.5 in. were extruded, comprising 8 percent $(16 \mathrm{~g})$ of the sampler volume. No drainable liquid was recovered, and 92 percent of the $187 \mathrm{~mL}$ sampler volume was air. The solids were cream and dark brown in color with a runny liquid. The sample was nonhomogeneous; the texture was runny and soft. No subsampling was performed on the sample.

The waste characteristics of the three cores are shown in Table B1-1. 
Table B1-1. Waste Characteristics Comparison.

\begin{tabular}{|c|c|c|c|c|c|c|}
\hline \multirow{2}{*}{ 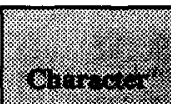 } & \multicolumn{2}{|c|}{ (2) } & \multicolumn{2}{|l|}{ 17: } & \multicolumn{2}{|c|}{ (3) } \\
\hline & 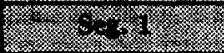 & $8+2$ & (2) & 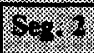 & 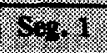 & $8 ; \%$; \\
\hline Color & Brown & $\mathrm{n} / \mathrm{a}^{1}$ & $\begin{array}{l}\text { Dark brown to } \\
\text { white }\end{array}$ & $\mathrm{n} / \mathrm{a}^{1}$ & $\begin{array}{l}\text { Dark } \\
\text { brown }\end{array}$ & $\begin{array}{l}\text { Cream } \\
\text { and dark } \\
\text { brown }\end{array}$ \\
\hline $\begin{array}{l}\text { Sample } \\
\text { number }\end{array}$ & 93-005 & $93-006$ & 93-007 & 93-008 & $93-011$ & $93-012$ \\
\hline Consistency & $\begin{array}{l}\text { Muddy texture } \\
\text { like soft, wet clay }\end{array}$ & $n / a^{1}$ & $\begin{array}{l}\text { Smooth, wet } \\
\text { texture; multiphase } \\
\text { consistency }\end{array}$ & $n / a^{1}$ & $\begin{array}{l}\text { Brittle, } \\
\text { crumbly }\end{array}$ & $\begin{array}{l}\text { Brittle, } \\
\text { crumbly }\end{array}$ \\
\hline$\%$ Liquid $^{2}$ & 0 & 56 & 5 & 91 & 0 & 0 \\
\hline$\%$ Solid $^{2}$ & 18 & $<3$ & 31 & 0 & 8 & 8 \\
\hline $\begin{array}{l}\text { Visual } \\
\text { homogeneity }\end{array}$ & Yes & No & No & Yes & $\mathrm{n} / \mathrm{a}^{1}$ & $n / a^{1}$ \\
\hline
\end{tabular}

Notes:

'Information is not available.

${ }^{2}$ Masses and volumes are shown in the text.

\section{B1.3 SAMPLE ANALYSIS}

An extensive set of analyses were required by Bell (1993), including tests for chemical, physical, rheological, and thermodynamic properties. This section discusses the analyses used to characterize the waste in tank 241-T-105.

Core 53 was analyzed only at the 222-S Laboratory, while core 54 was analyzed at the 222-S and 325 Laboratories. Analyses by the 222-S Laboratory were performed between April 14 and August 27, 1993. Core 57 was analyzed at the 325 Laboratory only. The

325 Laboratory performed analyses on core 54 , segment 1 , for plutonium, isotopic uranium, and TOC; and on core 57, segment 1, for physical and thermodynamic properties. Core 57, segment 2, analyses by the 325 Laboratory also included physical and thermodynamic properties. Analyses were performed between July 13 and September 7, 1993. The 222-S Laboratory performed the remaining analyses for metals, ions, radionuclides, and physical properties (Kocher 1993 and Giamberardini 1993). Analyses for organic constituents were not performed on tank 241-T-105. 
Cores 53 and 54 contained more liquid and fewer solids than expected. Because the amount of solids was not sufficient to perform all analyses required in Bell (1993), the analyses were prioritized in Silvers and Sasaki (1993). The imbalance in analytical results between the two cores is because the sample ran out. The liquids from core 53 were analyzed as outlined in Bell (1993). Only limited analyses were performed on the liquids from core 54, because the liquid was believed to be the water used as a hydrostatic head fluid during sampling (Silvers and Sasaki 1993). No core composites were made for either core because of the lack of sample. Similarly, no composites were made for core 57.

A homogenization test was also performed on segment 1 of cores 53 and 54 . There is a discrepancy between the laboratory case narrative in Giamberardini (1993) and the labels in the data tables about the analyses that were performed. The laboratory narrative states that the analyses used in the testing were ICP, gamma energy analysis (GEA), and total alpha; and that all homogenization test analyses were made on the acid digest for each subsample. The data tables, however, label many more analyses as homogenization test analyses. In addition, the data tables do not limit the homogenization tests to only acid digested subsamples; both fusion and water digested data is listed as homogenization data. Finally, the data tables also list some analyses on core 53 , segment 2 , as homogenization test analyses. For the purposes of the data tables listed in Section B2.0, the notation of the data tables contained in the data package has been maintained (that is, those results listed as homogenization test data in the laboratory package data tables have been denoted as homogenization test data in this TCR).

Table B1-2 shows the analyses that were performed on the solids of each segment, including the homogenization test analyses. Table B1-3 shows the analyses that were performed on the drainable liquid from each segment. Table B1-4 lists the procedures used for inorganic and radiological analyses. Table B1-5 lists procedures for physical and rheological analyses. 
Table B1-2. Analyses Performed on the Solids (by Segment).

\begin{tabular}{|c|c|c|c|c|}
\hline \multirow[b]{2}{*}{2010} & \multirow[b]{2}{*}{ S. } & \multicolumn{3}{|c|}{ 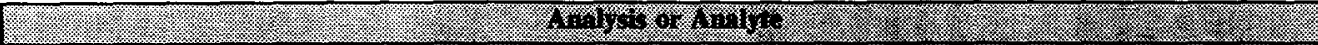 } \\
\hline & & 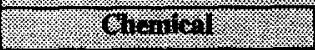 & IV & (3) \\
\hline 53 & 1 & & & DSC, TGA, particle size \\
\hline 54 & 1 & $\mathrm{TOC}^{1}, \mathrm{TIC}^{1}$ & mass spectrometry ${ }^{1}$, total alpha $\overline{\mathrm{Pu}}^{1}$ & wt\% solids (gravimetry)', particle size \\
\hline 57 & $1^{1}$ & -- & -- & $\begin{array}{l}\text { DSC, TGA, wt\% solids (gravimetry), } \\
\text { density, centrifuged solids density, } \\
\text { centrifuged supernate density, vol\% settled } \\
\text { solids, vol\% centrifuged solids, consistency } \\
\text { factor, yield point, flow behavior index, } \\
\text { wt\% centrifuged solids. }\end{array}$ \\
\hline 57 & $2^{1}$ & TIC & $-\cdots$ & $\begin{array}{l}\text { DSC, TGA, wt\% solids (gravimetry), } \\
\text { density, vol\% settled solids, volume } \% \\
\text { centrifuged solids. }\end{array}$ \\
\hline & & & 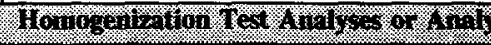 & 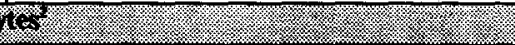 \\
\hline 53 & 2 & $\begin{array}{l}\mathrm{Hg}, \mathrm{Cr}^{+6}, \mathrm{CN}^{-}, \mathrm{OH}^{-}, \mathrm{NO}_{2} \\
\mathrm{IC}, \mathrm{TOC}, \mathrm{TIC} \\
\mathrm{ICP} \text { (acid, water, fusion) } \\
\mathrm{AA} \text { for Cs (acid; fusion), }\end{array}$ & $\begin{array}{l}\text { GEA (fusion; water), GEA (residual } \\
\text { solids), total alpha (fusion; water), total } \\
\text { beta (fusion; water) } \\
\text { U, }{ }^{241} \mathrm{Am},{ }^{99} \mathrm{Tc},{ }^{90} \mathrm{Sr},{ }^{239 / 240} \mathrm{Pu},{ }^{14} \mathrm{C} \text {, tritium }\end{array}$ & pH, total dissolved solids \\
\hline 54 & 1 & $\begin{array}{l}\text { ICP (acid, water, fusion), } \\
\mathrm{AA} \text { for } \mathrm{Cs} \text { (acid; fusion), } \\
\mathrm{Hg}, \mathrm{Cr}^{+6}, \mathrm{IC}, \mathrm{CN}, \mathrm{OH}^{-} \\
\mathrm{NO}_{2}, \mathrm{NH}_{4}^{+}, \mathrm{TOC}, \mathrm{TIC}\end{array}$ & $\begin{array}{l}\text { GEA (fusion; water), GEA (residual } \\
\text { solids), total alpha (fusion; water), total } \\
\text { beta (fusion; water), tritium, }{ }^{241} \mathrm{Am},{ }^{14} \mathrm{C} \text {, } \\
{ }^{2391240} \mathrm{Pu},{ }^{90} \mathrm{Sr},{ }^{99} \mathrm{Tc}, \mathrm{U}\end{array}$ & $\begin{array}{l}\text { pH, total dissolved solids, wt\% solids } \\
\text { (gravimetry), wt\% residual solids }\end{array}$ \\
\hline Notes: & $\begin{array}{l}\text { vol\% } \\
\text { }{ }^{1} \text { Anal } \\
\text { 'As d }\end{array}$ & $\begin{array}{l}\text { volume percent } \text { IC }=\text { ion } \mathrm{ch} \\
\mathrm{s} \text { were performed at PNNL. }\end{array}$ & $\begin{array}{l}\text { omatography ICP }=\text { inductively coupled pla } \\
\text { All others were performed at the } 222-S \text { Laboratory. } \\
\text { yses listed as homogenization test analyses in this ta }\end{array}$ & ble are those listed as such in the data tables fr \\
\hline
\end{tabular}


Table B1-3. Analyses Performed on the Drainable Liquid (by Segment).

\begin{tabular}{|c|c|c|c|c|}
\hline 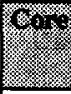 & 2. & 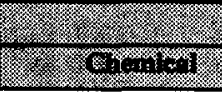 & 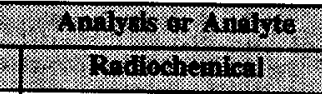 & 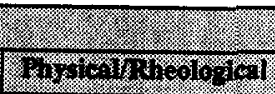 \\
\hline 53 & 2 & 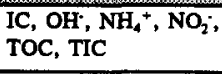 & $\begin{array}{l}\text { Total alpha, total beta, }{ }^{211} \mathrm{Am}, \\
{ }^{204} \mathrm{Pu},{ }^{290 / 200 \mathrm{Pu}},{ }^{\infty 0 \mathrm{Sr}},{ }^{\mathrm{T}} \mathrm{Tc}, \mathrm{U}\end{array}$ & $\begin{array}{l}\text { DSC, TGA, specific } \\
\text { gravity, pH }\end{array}$ \\
\hline 54 & 2 & IC & - & $\begin{array}{l}\text { DSC, TGA, specific } \\
\text { gravity, } \mathrm{pH}\end{array}$ \\
\hline
\end{tabular}

Table B1-4. Inorganic and Radiochemical Analytical Methods. ${ }^{1}$ (2 sheets)

\begin{tabular}{|c|c|c|}
\hline (2) & (12.8. & $1.3602 \times 110=$ \\
\hline Total metals & ICP spectrometry & LA-505-151 \\
\hline $\mathrm{Cr}(\mathrm{VI})$ & Spectrophotometry & LA-265-101 \\
\hline Hg & Cold vapor atomic absorption & LA-325-102 \\
\hline $\mathrm{F}, \mathrm{Cl}, \mathrm{NO}_{3}{ }^{-}, \mathrm{NO}_{2}^{-}, \mathrm{PO}_{4}^{3-}, \mathrm{SO}_{4}^{2-}$ & IC & LA-533-105 \\
\hline $\mathrm{NO}_{2}^{-}$ & Absorbance spectrometer & LA-645-001 \\
\hline $\mathrm{OH}^{-}$ & Potentiometric titration & LA-661-102 \\
\hline Total organic carbon & Coulometry & $\begin{array}{l}\text { LA-622-102/ } \\
\text { PNL-ALO-381 }\end{array}$ \\
\hline Total inorganic carbon & Coulometry & \begin{tabular}{|l|} 
LA-344-105/ \\
PNL-ALO-381
\end{tabular} \\
\hline $\mathrm{CN}$ & Distillation/spectrometry & $\begin{array}{l}\text { LA-695-101/ } \\
\text { LA-695-102 }\end{array}$ \\
\hline $\mathrm{NH}_{3}$ & Distillation/titration & LA-634-102 \\
\hline Total uranium & Laser fluorimetry & LA-925-106 \\
\hline Total alpha & Alpha proportional counting & LA-508-101 \\
\hline Total beta & Beta proportional counting & LA-508-101 \\
\hline${ }^{137} \mathrm{Cs},{ }^{60} \mathrm{Co},{ }^{241} \mathrm{Am}$ & GEA & LA-548-121 \\
\hline Isotopic uranium, plutonium & Mass spectrometry & PNL-ALO-455 \\
\hline $239 / 240 \mathrm{Pu},{ }^{241} \mathrm{Am}$ & Alpha spectrometry & $\begin{array}{l}\text { LA-503-156/ } \\
\text { PNL-ALO-423/421 }\end{array}$ \\
\hline${ }^{237} \mathrm{~Np}$ & Extraction/alpha energy analysis & LA-933-141 \\
\hline${ }^{90} \mathrm{Sr}$ & Extraction/beta proportional counting & LA-220-101 \\
\hline${ }^{96} \mathrm{Tc}$ & Liquid scintillation counting & LA-438-101 \\
\hline$\overline{129} 1$ & GEA & LA-378-101 \\
\hline
\end{tabular}


Table B1-4. Inorganic and Radiochemical Analytical Methods. ${ }^{1}$ (2 sheets)

\begin{tabular}{|l|l|l|}
\hline & & \\
\hline${ }^{14} \mathrm{C}$ & Liquid scintillation counting & LA-348-104 \\
\hline${ }^{3} \mathrm{H}$ & Liquid scintillation counting & LA-218-113 \\
\hline $\mathrm{pH}$ & Direct & LA-212-103 \\
\hline
\end{tabular}

Note:

'Kocher 1994

Table B1-5. Physical and Rheological Analytical Methods.

\begin{tabular}{|l|l|l|}
\hline Thermal properties & $\begin{array}{l}\text { Thermogravimetric analysis/ } \\
\text { Differential scanning calorimetry }\end{array}$ & $\begin{array}{l}\text { LA-561-112/ } \\
\text { LA-514-113 }\end{array}$ \\
\hline \% water/total dissolved solids & Thermogravimetric analysis & $\begin{array}{l}\text { LA-564-101/ } \\
\text { PNL-ALO-504 }\end{array}$ \\
\hline Specific gravity & Direct & LA-510-112 \\
\hline Density & Direct & PNL-ALO-501 \\
\hline Rheology & Direct & $\begin{array}{l}\text { PNL-ALO-501 } \\
\text { PNL-ALO-502 }\end{array}$ \\
\hline Particle size & Direct & $599-2-50.3$ \\
\hline
\end{tabular}

\section{B1.4 DESCRIPTION OF HISTORICAL SAMPLING EVENT}

The earliest information found was for a sample analyzed March, 1965 (Godfrey 1965). Analytical data was also available for a 1974 sample. Analytical results are summarized in Section B2.9. No information was available regarding sample handling, sample depth, or the riser. However, the 1974 sample does not reflect the current contents of the tank, because the tank was interim stabilized after samples were taken. 


\section{B2.0 ANALYTICAL RESULTS}

\section{B2.1 OVERVIEW}

This section summarizes the sampling and analytical results associated with the March and May 1993 sampling and analysis events of tank 241-T-105. The chemical, physical, rheological, and thermodynamic results associated with this tank are described in Table B2-1. All results were taken from Giamberardini (1993).

The quality control (QC) parameters assessed in conjunction with tank 241-T-105 samples included standard recoveries, spike recoveries, and duplicate analyses (relative percent differences [RPDs]). The QC criteria specified in the Tank Waste Remediation System Tank Waste Characterization Plan (Bell 1993) were 90 to 110 percent recovery for standards, 80 to 120 percent recovery for spikes, and $\leq 20$ percent for RPDs. These criteria applied to all analytes. Sample and duplicate pairs, in which any of these three QC parameters were outside of their limits, are footnoted in the sample mean column of the following data summary tables with an a, b, c, d, or e as follows:

- $\quad$ " $\mathrm{a}$ " indicates the standard recovery was below the QC limit.

- $\quad$ "

- $\quad \mathrm{c}$ " indicates the spike recovery was below the QC limit.

- $\quad \mathrm{d}$ " indicates the spike recovery was above the QC limit.

- $" e "$ indicates the RPD was greater than the QC limit. 
Table B2-1. Analytical Data Presentation Tables.

\begin{tabular}{|l|l|}
\hline Metals by atomic absorption spectroscopy & B2- \\
\hline Metals by cold vapor atomic absorption spectroscopy & $\mathrm{B} 2-3$ \\
\hline Metals by ICP spectroscopy & $\mathrm{B} 2-4$ through B2-34 \\
\hline Metals by laser fluorimetry & $\mathrm{B} 2-35$ \\
\hline Hexavalent chromium by spectrophotometry & $\mathrm{B} 2-36$ \\
\hline Ammonia by distillation/titration & $\mathrm{B} 2-37$ \\
\hline pH & $\mathrm{B} 2-38$ \\
\hline Anions by IC & $\mathrm{B} 2-39$ through B2-44 \\
\hline Hydroxide by potentiometric titration & $\mathrm{B} 2-45$ \\
\hline Cyanide by distillation/spectrometry & $\mathrm{B} 2-46$ \\
\hline Nitrite by spectrophotometry & $\mathrm{B} 2-47$ \\
\hline Analyses for TC/TOC/TIC & $\mathrm{B} 2-48$ through B2-51 \\
\hline Radionuclides by mass spectroscopy & $\mathrm{B} 2-52$ through B2-60 \\
\hline Radionuclides by alpha proportional counting & $\mathrm{B} 2-61$ \\
\hline Radionuclides by alpha spectroscopy & $\mathrm{B} 2-62$ through B2-65 \\
\hline Radionuclides by beta proportional counting & $\mathrm{B} 2-66$ and B2-67 \\
\hline Radionuclides by GEA & $\mathrm{B} 2-68$ through B2-79 \\
\hline Radionuclides by liquid scintillation counting & $\mathrm{B} 2-80$ through B2-82 \\
\hline Analysis for physical properties & $\mathrm{B} 2-83$ through B2-95 \\
\hline Analysis for DSC & $\mathrm{B} 2-96$ \\
\hline Analysis for thermogravimetric properties & $\mathrm{B} 2-97$ \\
\hline & \\
\hline
\end{tabular}

Blanks were also prepared and analyzed with the sample analyses. Bell (1993) established a limit for blank concentration of $\leq 20$ percent of the sample value. No contamination greater than the established limit was discovered in any sample. Therefore, no footnoting of the data tables in Section B2.0 was needed.

\section{B2.2 INORGANIC ANALYSES}

A full suite of metals were analyzed by ICP. In addition, cesium was analyzed by atomic absorption spectroscopy, mercury was analyzed by cold vapor atomic absorption spectroscopy, and uranium was measured by laser fluorimetry. Chromium (VI) analysis was performed on the water digests of cores 53 and 54 by spectrophotometry. 


\section{B2.2.1 Atomic Absorption Spectroscopy}

Cesium analysis was completed using procedure LA-505-122, Rev. E-2. Cesium analysis was performed on fusion and acid digestions of the solid homogenization samples. The results were below the detection limits.

\section{B2.2.2 Cold Vapor Atomic Absorption Spectroscopy}

Mercury concentration in the samples was measured using cold vapor atomic absorption spectroscopy according to procedure LA-325-104, Rev. A-0 and Rev. A-1. Mercury analysis was performed on the direct solids on cores 53 and 54.

\section{B2.2.3 Inductively Coupled Plasma}

Samples were prepared by acid digestion, water digestion, or KOH fusion digestion. The ICP analyses were performed according to procedure LA-505-151. The major waste constituents identified by $\mathrm{ICP}$ spectroscopy were $\mathrm{Al}, \mathrm{Bi}, \mathrm{Ca}, \mathrm{Fe}, \mathrm{Mg}, \mathrm{Mn}, \mathrm{P}, \mathrm{Si}, \mathrm{Na}$, and $\mathrm{S}$; all were present in concentrations exceeding $1,000 \mu \mathrm{g} / \mathrm{g}$. Phosphorus and sulfur were analyzed as a cross-check for the phosphate and sulfate results reported from IC analyses.

\section{B2.2.4 Laser Fluorimetry}

Uranium was analyzed by laser fluorimetry on fusion digestions of the solids and directly on the drainable liquids according to procedure LA-925-106.

\section{B2.2.5 Chromium (VI) by Spectrophotometry}

Hexavalent chromium was analyzed according to procedure LA-265-101, Rev. A-1 after a water leach on the solids.

\section{B2.2.6 Distillation/Titration}

Ammonia analysis of tank 241-T-105 samples was performed according to procedure LA-634-102, Rev. D-0 and Rev. D-1. Ammonia analysis was performed on drainable liquids, core homogenizations, and hot cell and field blanks (Giamberardini 1993). No ammonia was detected. 


\section{B2.2.7 pH}

Analysis of the $\mathrm{pH}$ for tank 241-T-105 samples was performed according to procedure LA-212-102 for liquid samples and procedure LA-212-103, Rev. C-4 for solid samples. The pH was measured on drainable liquids, core homogenizations, and hot cell and field blanks.

\section{B2.2.8 Ion Chromatography}

Anions were determined on a water digestion of the sample according to procedure LA-533-105. Ion chromatography was used to determine fluoride, chloride, nitrate, nitrite, phosphate, and sulfate concentrations. The most abundant anion in the tank 241-T-105 waste was nitrite. Nitrate exhibited the second highest concentration among anions. Sulfate, phosphate, chloride, and fluoride were present to a lesser extent.

\section{B2.2.9 Potentiometric Titration}

The hydroxide concentration was measured by potentiometric titration according to procedure LA-661-102.

\section{B2.2.10 Distillation/Spectrometry}

Cyanide analysis of the tank 241-T-105 samples was performed by distillation/spectrometry according to procedure LA-695-102, Rev. B-0. The analysis was performed on segment 1 of cores 53 and 54 by direct analysis.

\section{B2.2.11 Nitrite by Spectrophotometry}

Nitrite analysis by spectrophotometry was performed according to procedure LA-645-001, Rev. A-4. Nitrite analysis was performed on the drainable liquids and on water digestions of the solids.

\section{B2.3 ORGANIC ANALYSES}

Volatile and semi-volatile organic analyses were not conducted on samples obtained from $\operatorname{tank}$ 241-T-105. However, volatile and semivolatile target analytes are not expected to be present in the tank because of their volatile nature and relatively small contribution to the waste as indicated by the historical records. Data from the total organic carbon analyses reveal that organic carbon does exist in tank $241-\mathrm{T}-105$, probably in the form of complexant decomposition products (DiCenso et al. 1994). 


\section{B2.4 CARBON ANALYSES}

\section{B2.4.1 Total Organic Carbon}

Total organic carbon (TOC) analysis was performed according to procedures LA-344-105 and PNL-ALO-381, Rev. 0. The TOC analyses were performed on the drainable liquid, the two core segments that had solids, and the field and hot cell blanks.

\section{B2.4.2 Total Inorganic Carbon}

Total inorganic carbon (TIC) analysis was performed on the same samples as the TOC analyses, according to procedures LA-622-102, Rev. B-2 and PNL-ALO-381.

\section{B2.5 RADIONUCLIDE ANALYSES}

A variety of analytical methods were used to analyze the radionuclide content of the tank waste. Gamma energy analysis was used to measure the activities of ${ }^{241} \mathrm{Am},{ }^{144} \mathrm{Ce} / \mathrm{Pr},{ }^{134} \mathrm{Cs}$, ${ }^{137} \mathrm{Cs},{ }^{60} \mathrm{Co},{ }^{154} \mathrm{Eu},{ }^{40} \mathrm{~K},{ }^{103} \mathrm{Ru},{ }^{106} \mathrm{Ru} / \mathrm{Rh}$, and ${ }^{228} \mathrm{Th}$. The liquid scintillation counting procedure was used to analyze for ${ }^{95} \mathrm{Tc},{ }^{14} \mathrm{C}$, and ${ }^{3} \mathrm{H}$. Americium-241, ${ }^{238} \mathrm{Pu}$, and ${ }^{239}{ }^{240} \mathrm{Pu}$ were measured by alpha spectroscopy. Mass spectroscopy was used to determine the uranium and plutonium isotopes. The major radioactive constituents in the waste were ${ }^{137} \mathrm{Cs}$ and ${ }^{90} \mathrm{Sr}$.

\section{B2.5.1 Mass Spectroscopy}

Isotopic uranium and plutonium were determined by PNL-ALO-455 on the fused sample. The uranium and plutonium concentrations were measured using mass spectroscopy.

\section{B2.5.2 Total Alpha and Alpha Emitters}

The total alpha concentration was measured on the solids and liquids using alpha proportional counting. The analyses were performed according to procedures LA-508-101, LA-503-156, and LA-508-104. The results are shown in Tables B2-61a through B2-61c. Total plutonium, ${ }^{241} \mathrm{Am},{ }^{238} \mathrm{Pu}$, and ${ }^{239 / 240} \mathrm{Pu}$ were measured by alpha spectroscopy. 


\section{B2.5.3 Total Beta Activity}

The total beta concentration was measured using beta proportional counting according to procedures LA-508-101 and LA-508-114. Measurements were performed directly on the liquids and solids after water and fusion digestions. Strontium- 90 also was measured by beta: proportional counting. Strontium analyses were performed according to procedure LA-220-101, Rev. D-0. The analyses were performed on the drainable liquid and the solids after a fusion digestion.

\section{B2.5.4 Gamma Energy Analysis}

The gamma energy analyses were performed according to procedure LA-548-121 Rev. D-0 and LA-508-052, Rev. B-4. The GEA analyses were performed on the solids after fusion and water digestions and the hot cell blank.

\section{B2.5.5 Liquid Scintillation Counting}

Carbon-14, ${ }^{3} \mathrm{H}$, and ${ }^{99} \mathrm{Tc}$ analyses were performed by liquid scintillation counting.

Carbon-14 analyses were performed according to procedure LA-348-104, Rev. B-0. The ${ }^{14} \mathrm{C}$ analyses were performed on the water digested solids.

Tritium $\left({ }^{3} \mathrm{H}\right)$ analyses were performed on the water digested solids according to procedure LA-218-114, Rev, A-1 and A-2.

Technetium analyses were performed according to procedure LA-438-101, Rev. D-1. The analyses were performed on the drainable liquid and the fusion digested solids.

\section{B2.6 PHYSICAL ANALYSES}

\section{B2.6.1 Percent Solids, Density, and Specific Gravity}

Analysis for weight percent solids was carried out at the 222-S and the 325 Laboratories using gravimetric methods. The procedures used for these analyses were LA-564-101 Rev. E-3 and PNL-ALO-504.

In addition to weight percent total solids, weight percent analyses were performed on centrifuged solids from core 57, segment 1 , exhibiting a result of 98 weight percent. The results are shown in Table B2-84. A weight percent solids determination also was performed on the residual solids from a water digestion of the solids from segment 1 of core 54 . 
Density measurements were determined directly. The density of segment 1 of core 57 was $1.54 \mathrm{~g} / \mathrm{mL}$; that of core 57 segment 2 was $1.74 \mathrm{~g} / \mathrm{mL}$. Density also was measured on diluted samples (1:3 and $1: 1$ dilutions) of segment 1 of core 57 . The $1: 1$ dilution gave a density of $1.12 \mathrm{~g} / \mathrm{mL}$, and the $1: 3$ dilution gave a density of $1.03 \mathrm{~g} / \mathrm{mL}$.

Densities were calculated on all segments by dividing the segment mass by the segment volume. In addition to the densities of the segments, density measurements were made on core 57 , segment 1 centrifuged supernate $(1.0 \mathrm{~g} / \mathrm{mL})$ and centrifuged solids $(1.56 \mathrm{~g} / \mathrm{mL})$.

Specific gravity was measured on segment 2 of cores 53 and 54 . The results for the drainable liquid samples were 1.05 on core 53 and 0.985 on core 54 .

Volume percent analyses were performed on settled solids from segment 1 and 2 of core 57. The volume percent results for both segments were 100 volume percent solids, showing that no drainable liquid existed in the samples. A 1:1 and a 1:3 dilution of samples from both segments of core 57 was also carried out. Centrifuged solids exhibited volume percent results of 96 volume percent and 98 volume percent for segments 1 and 2 , respectively.

\section{B2.6.2 Total Dissolved Solids}

The analysis for total dissolved solids is the same as that for the weight percent solids except that it is performed on a liquid sample. For tank 241-T-105, this analysis was performed on water digested solids from cores 53 and 54. Procedure LA-546-101, Rev. 3, was used for this analysis. The average result for core 54 , segment 1 , was 0.105 percent, and 0.28 percent for core 53, segment 1 .

\section{B2.6.3 Particle Size}

Particle size distribution analysis was performed on the as-received samples from segments 1 and 2 of core 57 . The mean diameter based on probability number density for both segments was $1.0 \mu \mathrm{m}$. The mean diameter based on probability volume density was $10 \mu \mathrm{m}$ for segment 1 and $17 \mu \mathrm{m}$ for segment 2. Particle size was also measured on samples from segment 1 both of cores 53 and 54. For segment 1 of core 53 the mean diameter based on probability number density was $1.5 \mu \mathrm{m}$ and the mean diameter based on probability volume density was $1.5 \mu \mathrm{m}$. For segment 1 of core 54 , the probability number density was $1.5 \mu \mathrm{m}$, and the mean diameter based on the probability volume density was $20 \mu \mathrm{mM}$. Plots of the particle size distribution based on the probability number density and the probability volume density are in the data package (Giamberardini 1993). 


\section{B2.6.4 Rheology}

Viscosity versus shear rate studies were performed on samples obtained from segments 1 and 2 of core 57. Segment 1 exhibited pseudoplastic behavior, that is, the viscosity of the waste decreased with increasing shear rate. The viscosity of a $1: 1$ dilution of segment 1 at ambient temperature decreased from 200 centipoise to 20 centipoise as shear rate increased from $50 \mathrm{~s}^{-1}$ to $450 \mathrm{~s}^{-1}$. These data were fit to a yield power law equation (Giamberardini 1993). The 1:1 dilution of segment 2, however, displayed Newtonian behavior since the viscosity was relatively independent of shear rate; a slight decrease from 5 centipoise to 1 centipoise was observed as shear rate increased from $50 \mathrm{~s}^{-1}$ to $450 \mathrm{~s}^{-1}$. Plots of shear stress and viscosity as a function of shear rate for the dilutions are in the data package (Giamberardini 1993)

\section{B2.7 THERMODYNAMIC ANALYSES}

\section{B2.7.1 Differential Scanning Calorimetry}

In a DSC analysis, heat absorbed or emitted by a substance is measured while the temperature of the sample is heated at a constant rate. Nitrogen is passed over the sample material to remove any gases being released. The onset temperature for an endothermic or exothermic event is determined graphically.

The DSC analyses for tank 241-T-105 were performed according to procedure LA-514-113, Rev. A-0. The DSC analyses yielded exotherms in samples originating from cores 53 and 57; however, exotherms were not observed in the core 54 samples. The DSC plots of the samples also generally yielded two endothermic transition regions. Only exothermic results are shown in the tables.

For segment 1 of core 53, small exotherms were found in transitions two and three. These transitions occurred at peak temperatures of approximately $333{ }^{\circ} \mathrm{C}\left(320^{\circ} \mathrm{C}\right.$ to $350{ }^{\circ} \mathrm{C}$ range) and $447^{\circ} \mathrm{C}$ (420 ${ }^{\circ} \mathrm{C}$ to $460^{\circ} \mathrm{C}$ range). These exotherms released, on a wet weight basis, $13.0 \mathrm{~J} / \mathrm{g}$ and $17.3 \mathrm{~J} / \mathrm{g}$, respectively. Segment 1 of core $57 \mathrm{had}$ a broad exotherm in the 150 to $320^{\circ} \mathrm{C}$ range with an average $175 \mathrm{~J} / \mathrm{g}$ energy release (wet weight basis).

The safety screening criterion of $480 \mathrm{~J} / \mathrm{g}$ is based on a dry sample basis (Dukelow et al. 1995). Because the above results are reported on a wet weight basis, the results have been recalculated on a dry weight basis for comparison. Segment 1 of core 53 had a water content of 51.97 percent; therefore, the energy released was $27.1 \mathrm{~J} / \mathrm{g}$ at $333{ }^{\circ} \mathrm{C}\left(630^{\circ} \mathrm{F}\right)$ and $36 \mathrm{~J} / \mathrm{g}$ at $447^{\circ} \mathrm{C}\left(840^{\circ} \mathrm{F}\right)$. Segment 1 of core 57 contained 47.6 percent water; therefore, the energy released on a dry weight basis was $334 \mathrm{~J} / \mathrm{g}$ in the temperature range $150^{\circ} \mathrm{C}$ to $320^{\circ} \mathrm{C}\left(302^{\circ} \mathrm{F}\right.$ to $\left.608^{\circ} \mathrm{F}\right)$. These exotherms are below the safety screening criterion. 


\section{B2.7.2 Thermogravimetric Analyses}

Thermogravimetric analysis (TGA) measures the mass of a sample while the temperature of the sample is increased at a constant rate. Nitrogen is passed over the sample during heating to remove any released gases. Any decrease in the weight of a sample during TGA represents a loss of gaseous matter from the sample through evaporation or a reaction that forms gas phase products. The moisture content is estimated by assuming that all TGA sample weight loss up to a certain temperature (typically $150^{\circ} \mathrm{C}$ to $200^{\circ} \mathrm{C}$ ) is caused by water evaporation. The temperature limit for moisture loss is chosen by the operator at an inflection point on the TGA plot. Likewise, other volatile matter fractions can often be differentiated by inflection points.

Tank 241-T-105 samples were analyzed by TGA according to procedure LA-560-112, Rev. A-1 or procedure RDS-TA-1. Segment 1 of core 53 had a loss of 51.97 percent between room temperature and $135{ }^{\circ} \mathrm{C}$, and segment 2 of core 53 had an average loss of 91.39 percent between room temperature and about $100{ }^{\circ} \mathrm{C}$. Segment 2 of core 54 had a loss of 35.52 percent between room temperature and $130^{\circ} \mathrm{C}$. Segments 1 and 2 of core 57 had average losses of 47.6 percent (between $30^{\circ} \mathrm{C}$ and $153{ }^{\circ} \mathrm{C}$ ) and 20 percent (between $31^{\circ} \mathrm{C}$ and $\left.120^{\circ} \mathrm{C}\right)$, respectively.

\section{B2.8 VAPOR PHASE MEASUREMENT}

Vapor phase measurements of the tank headspace were obtained on May 9, 1996, through riser 8. These measurements support the safety screening DQO (Dukelow et al. 1995). The flammability of the headspace vapors was 0 percent of the LFL. The TOC concentration was $150 \mathrm{ppm}$, with an ammonia concentration of $5 \mathrm{ppm}$.

\section{B2.9 HISTORICAL SAMPLE RESULTS}

Analytical data is available for a sampling of tank 241-T-105 liquid in 1974. Sample T-4927 was dark amber in color, and had traces of solids (Wheeler 1974). As stated in Section B1.4, no other information regarding the sampling event was available. Analytical results from the sample collected in 1974 are shown in Table B2-98. These data have not been validated and should be used with caution. 
Table B2-2. Tank 241-T-105 Analytical Results: Cesium (Atomic Absorption).

\begin{tabular}{|l|l|l|l|l|l|}
\hline & & & & \\
\hline
\end{tabular}

Table B2-3. Tank 241-T-105 Analytical Results: Mercury (CVAA).

\begin{tabular}{|c|c|c|c|c|c|}
\hline a. & $\frac{1}{4}$ & 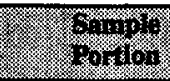 & 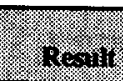 & 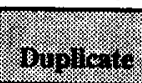 & 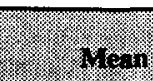 \\
\hline \multicolumn{2}{|c|}{ 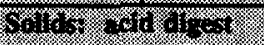 } & & 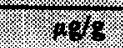 & 1048 & \% \\
\hline $25-5798$ & 53: 1 & Homog. test & 41 & 32.7 & $36.85^{\mathrm{QC:}}$ \\
\hline $33-5798$ & $54: 1$ & Homog. test & 11.8 & 10.2 & $11^{\mathrm{QC}: c}$ \\
\hline
\end{tabular}

Table B2-4. Tank 241-T-105 Analytical Results: Aluminum (ICP).

\begin{tabular}{|c|c|c|c|c|c|}
\hline 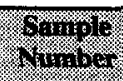 & $\frac{6}{610}$ & (3), & 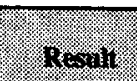 & Oupitivite. & Menin \\
\hline \multicolumn{2}{|c|}{$3^{3}$ (n) } & & 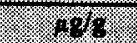 & (1) & \% \\
\hline $25-8755$ & 53: 1 & Homog. test & 30,000 & 32,700 & $31,350^{\mathrm{Qc}: b}$ \\
\hline $33-8755$ & \multirow[t]{3}{*}{ 54: 1} & Homog. test & $1.52 \mathrm{E}+05$ & $1.55 \mathrm{E}+05$ & $1.54 \mathrm{E}+05^{\mathrm{QC}: b, d}$ \\
\hline $41-8755$ & & Homog. test & $1.84 \mathrm{E}+05$ & $1.73 E+05$ & $1.79 \mathrm{E}+05^{\mathrm{QC}: b, d}$ \\
\hline $40-8755$ & & Homog. test & $1.86 \mathrm{E}+05$ & $1.90 \mathrm{E}+05$ & $1.88 \mathrm{E}+05^{\mathrm{oC}: \mathrm{b}}$ \\
\hline \multicolumn{3}{|c|}{ (2) } & $48 \%$ & 488 & 40 \\
\hline $25-6775$ & 53:1 & Homog. test & 37,400 & 41,100 & $39,250^{\mathrm{QC:d}}$ \\
\hline $33-6755$ & $54: 1$ & Homog. test & $1.52 \mathrm{E}+05$ & $1.50 \mathrm{E}+05$ & $1.51 \mathrm{E}+05^{\overline{\mathrm{QC}} \mathrm{d}}$ \\
\hline \multicolumn{3}{|c|}{ 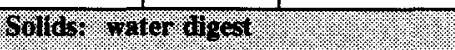 } & ngs & 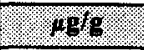 & 4igs \\
\hline $25-7755$ & $53: 1$ & Homog. test & 152 & 154 & 153 \\
\hline $33-7755$ & 54: 1 & Homog. test & 348 & 476 & $412^{\mathrm{QC}: \mathrm{e}}$ \\
\hline
\end{tabular}


Table B2-5. Tank 241-T-105 Analytical Results: Antimony (ICP).

\begin{tabular}{|c|c|c|c|c|c|}
\hline 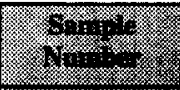 & 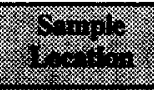 & $\left(\frac{1}{4}\right)$ & . 12.31. & 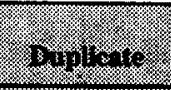 & 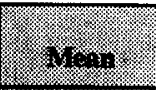 \\
\hline 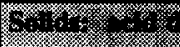 & 8 & (2) & 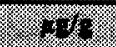 & 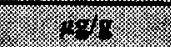 & \% \\
\hline $25-8755$ & 53: 1 & Homog. test & $<126$ & $<125$ & $<125.5^{\mathrm{QC}: \mathrm{A}}$ \\
\hline $33-8755$ & \multirow[t]{3}{*}{ 54: 1} & Homog. test & $<128$ & $<128$ & $<128^{Q C: n}$ \\
\hline $41-8755$ & & Homog. test & $<127$ & $<128$ & $<127.5$ \\
\hline $40-8755$ & & Homog. test & $<129$ & $<129$ & $<129$ \\
\hline 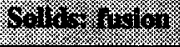 & & & $9 \%$ & 80 & $.4 \%$ \\
\hline $25-6775$ & 53: 1 & Homog. test & $<103$ & $<104$ & $<103.5$ \\
\hline $33-6755$ & 54: 1 & Homog. test & $<105$ & $<103$ & $<104$ \\
\hline $60 \%=r . \%$ & (1) & 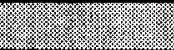 & $48 \%$ & 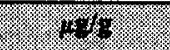 & 1901 \\
\hline $25-7755$ & 53: 1 & Homog. test & 25.4 & 22 & 23.7 \\
\hline 33-7755 & 54: 1 & Partial & $<132$ & $<132$ & $<132$ \\
\hline
\end{tabular}

Table B2-6. Tank 241-T-105 Analytical Results: Arsenic (ICP).

\begin{tabular}{|c|c|c|c|c|c|}
\hline 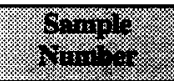 & 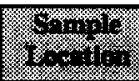 & (3) & 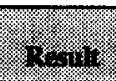 & binglig. & $4 \%$ \\
\hline \multicolumn{3}{|c|}{ 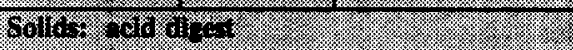 } & 104 & 1.9.1: & (1) \\
\hline $25-8755$ & 53:1 & Homog. test & $<26.5$ & $<26.1$ & $<26.3$ \\
\hline $33-8755$ & \multirow[t]{3}{*}{ 54: 1} & Homog. test & $<26.8$ & $<26.9$ & $<26.85$ \\
\hline $41-8755$ & & Homog. test & $<26.6$ & $<26.8$ & $<26.7$ \\
\hline $40-8755$ & & Homog. test & $<26.9$ & $<26.9$ & $<26.9$ \\
\hline \multicolumn{3}{|c|}{ 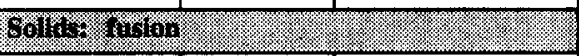 } & 180 & 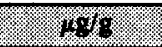 & 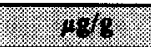 \\
\hline $25-6775$ & $53: 1$ & Homog. test & $<14.8$ & $<14.8$ & $<14.8$ \\
\hline $33-6755$ & 54: 1 & Homog. test & $<14.9$ & 26 & $<20.45^{\mathrm{QC}: \mathrm{e}}$ \\
\hline \multicolumn{3}{|c|}{ Solwisy woter difert } & $18+4$ & 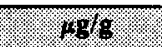 & 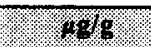 \\
\hline $25-7755$ & 53:1 & Homog. test & $<3.08$ & $<3.08$ & $<3.08$ \\
\hline $33-7755$ & 54: 1 & Homog. test & $<27.7$ & $<27.7$ & $<27.7$ \\
\hline
\end{tabular}


Table B2-7. Tank 241-T-105 Analytical Results: Beryllium (ICP).

\begin{tabular}{|c|c|c|c|c|c|}
\hline 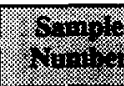 & 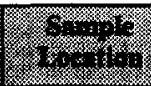 & Sis & 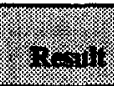 & 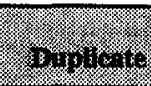 & r. \\
\hline 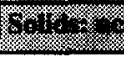 & (2) & & $8 \%$ & 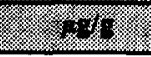 & h \\
\hline $25-8755$ & 53: 1 & Homog. test & $<2.94$ & $<2.9$ & $<2.92$ \\
\hline $33-8755$ & \multirow[t]{3}{*}{ 54: 1} & Homog. test & $<2.97$ & $<2.99$ & $<2.98$ \\
\hline $41-8755$ & & Homog. test & $<2.95$ & $<2.98$ & $<2.965$ \\
\hline $40-8755$ & & Homog. test & $<2.99$ & $<2.99$ & $<2.99$ \\
\hline \multicolumn{3}{|c|}{ 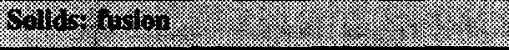 } & $1 \%$ & (1) & (x) \\
\hline $25-6775$ & 53: 1 & Homog. test & $<1.48$ & $<1.48$ & $<1.48$ \\
\hline $33-6755$ & $54: 1$ & Homog. test & $<1.49$ & $<1.47$ & $<1.48$ \\
\hline \multicolumn{3}{|c|}{ 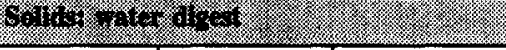 } & $14+$ & 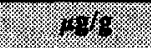 & \% \\
\hline $25-7755$ & 53: 1 & Homog. test & $<0.308$ & $<0.308$ & $<0.308$ \\
\hline $33-7755$ & $54: 1$ & Homog. test & $<3.08$ & $<3.08$ & $<3.08$ \\
\hline
\end{tabular}

Table B2-8. Tank 241-T-105 Analytical Results: Bismuth (ICP).

\begin{tabular}{|c|c|c|c|c|c|}
\hline 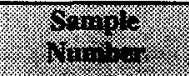 & 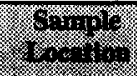 & 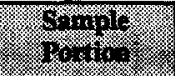 & (3.) & s. & (2) \\
\hline 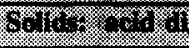 & 14. & (2) & 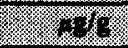 & 48 & 48 \\
\hline $25-8755$ & 53: 1 & Homog. test & 1,190 & 1,320 & $1,255^{\mathrm{QC:a}}$ \\
\hline $33-8755$ & \multirow[t]{3}{*}{ 54: 1} & Homog. test & 1,360 & 1,440 & $1,400^{\mathrm{OC}: \mathrm{A}}$ \\
\hline $41-8755$ & & Homog. test & 1,300 & 1,470 & $1,385^{\mathrm{QC} ; \mathrm{a}}$ \\
\hline $40-8755$ & & Homog. test & 1,300 & 1,280 & $1,290^{\mathrm{QC}: \mathrm{a}}$ \\
\hline 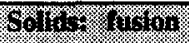 & & & $.18 \%$ & 1498 & . \\
\hline $25-6775$ & 53: 1 & Homog. test & 999 & 1,110 & $1,054.5^{\mathrm{CC}: \mathrm{c}}$ \\
\hline $33-6755$ & $54: 1$ & Homog. test & 1,190 & 1,570 & $1,380^{\mathrm{QC}: \mathrm{c}, \mathrm{e}}$ \\
\hline 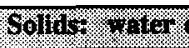 & 194 & & 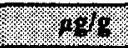 & 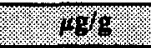 & (1) \\
\hline $25-7755$ & 53: 1 & Homog. test & $<6.47$ & $<6.46$ & $<6.465^{Q C: c}$ \\
\hline $33-7755$ & $54: 1$ & Homog. test & $<44.1$ & $<44.1$ & $<44.1$ \\
\hline
\end{tabular}


Table B2-9. Tank 241-T-105 Analytical Results: Boron (ICP).

\begin{tabular}{|c|c|c|c|c|c|}
\hline (2) & 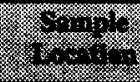 & 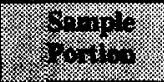 & 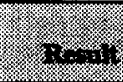 & 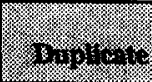 & 4 \\
\hline $30 \%, \%$ & 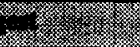 & 28 & 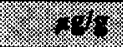 & 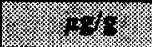 & $8 \%$ \\
\hline $25-8755$ & 53: 1 & Homog. test & $<22.5$ & $<22.2$ & $<22.35^{\text {QC }: b}$ \\
\hline $33-8755$ & \multirow[t]{3}{*}{ 54: 1} & Homog. test & $<22.8$ & $<22.9$ & $<22.85^{\mathrm{QC}: \mathrm{b}}$ \\
\hline $41-8755$ & & Homog. test & $<22.6$ & $<22.8$ & $<22.7^{\alpha \mathrm{C}: b}$ \\
\hline $40-8755$ & & Homog. test & $<23$ & $<23$ & $<23^{\circ \mathrm{OC} b}$ \\
\hline 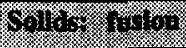 & 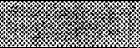 & (2) & $=0 \%$ & 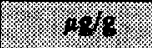 & 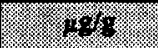 \\
\hline $25-6775$ & 53: 1 & Homog. test & $<4.92$ & $<4.94$ & $<4.93$ \\
\hline $33-6755$ & 54: 1 & Homog. test & $<4.98$ & $<4.9$ & $<4.94$ \\
\hline $604 \%=1 \%$ & 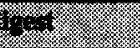 & &.$=10 \%$ & 1.784 & 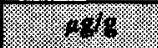 \\
\hline $25-7755$ & 53: 1 & Homog. test & 321 & 284 & $302.5^{\mathrm{QC}: b}$ \\
\hline 33-7755 & 54: 1 & Homog. test & 320 & 415 & $367.5^{\mathrm{QC}: c}$ \\
\hline
\end{tabular}

Table B2-10. Tank 241-T-105 Analytical Results: Cadmium (ICP).

\begin{tabular}{|c|c|c|c|c|c|}
\hline Compl & 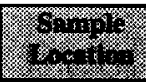 & 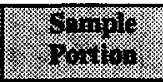 & 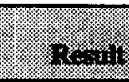 & 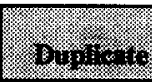 & $4 \%$ \\
\hline \multicolumn{3}{|c|}{ 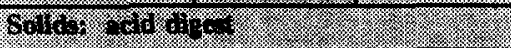 } & $2=4$ & 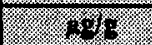 & 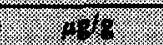 \\
\hline $25-8755$ & $53: 1$ & Homog. test & 26.2 & 12.9 & $19.55^{\mathrm{QC:A,C}}$ \\
\hline $33-8755$ & \multirow[t]{3}{*}{$54: 1$} & Homog. test & 5.26 & $<3.98$ & $<4.62^{\mathrm{QC}: \mathrm{e}}$ \\
\hline $41-8755$ & & Homog. test & $<3.94$ & 15.9 & $<9.92^{\text {QC:e }}$ \\
\hline $40-8755$ & & Homog. test & 4.35 & 5.67 & $5.01^{\mathrm{QC}: \mathrm{a}, \mathrm{e}}$ \\
\hline \multicolumn{3}{|l|}{ 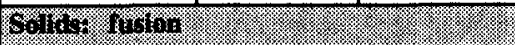 } & 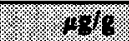 & 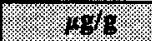 & $4=48$ \\
\hline $25-6775$ & 53: 1 & Homog. test & 18.3 & 20.1 & 19.2 \\
\hline $33-6755$ & 54:1 & Homog. test & 12.1 & 11 & 11.55 \\
\hline \multicolumn{2}{|c|}{ Sollts. water ofigert } & 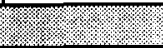 & 14018 & 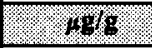 & 1008 \\
\hline $25-7755$ & 53: 1 & Homog. test & 4.1 & 1.52 & $2.81^{\text {CO:e }}$ \\
\hline $33-7755$ & 54: 1 & Homog. test & $<4.1$ & $<4.11$ & $<4.105$ \\
\hline
\end{tabular}


Table B2-11. Tank 241-T-105 Analytical Results: Calcium (ICP).

\begin{tabular}{|c|c|c|c|c|c|}
\hline$\left(\frac{1}{4}\right)$ & (x) & $l_{k}$ & 90 & 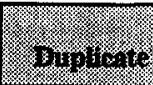 & (1) \\
\hline \multicolumn{3}{|c|}{ 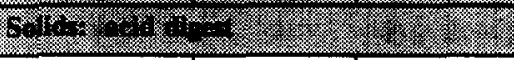 } & 41 & 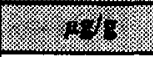 & $2 \%$ \\
\hline $25-8755$ & 53: 1 & Homog. test & 1,410 & 1,590 & $1,500^{\alpha c: b}$ \\
\hline $33-8755$ & \multirow[t]{3}{*}{ 54: 1} & Homog. test & 1,380 & 1,290 & $1,335^{Q C: b}$ \\
\hline $41-8755$ & & Homog. test & 1,320 & 1,340 & $1,330^{\mathrm{Qc}: \mathrm{b}}$ \\
\hline $40-8755$ & & Homog. test & 1,120 & 1,170 & $1,145^{\mathrm{QC}: \mathrm{b}}$ \\
\hline \multicolumn{3}{|l|}{ 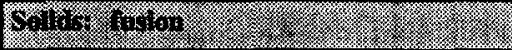 } & . & $4 \%$ & (2) \\
\hline $25-6775$ & 53: 1 & Homog. test & 7,170 & 2,930 & $5,050^{Q C: e}$ \\
\hline $33-6755$ & $54: 1$ & Homog. test & 1,580 & 3,000 & $2,290^{\alpha C: c, e}$ \\
\hline \multicolumn{3}{|c|}{$601+1 \%) \%(1)$} & 1. & (2.) & (2) $/ 4 / 9$ \\
\hline $25-7755$ & 53: 1 & Homog, test & 108 & 126 & 117 \\
\hline $33-7755$ & $54: 1$ & Homog. test & 209 & 705 & $457^{\mathrm{QC:e}}$ \\
\hline
\end{tabular}

Table B2-12. Tank 241-T-105 Analytical Results: Cerium (ICP).

\begin{tabular}{|c|c|c|c|c|c|}
\hline$\frac{1}{4}$ & 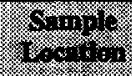 & 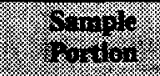 & $(2 x+1$ & 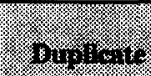 & 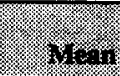 \\
\hline \multicolumn{2}{|c|}{ 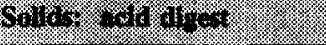 } & & (1) & 4 & $\%$ \\
\hline $25-8755$ & 53: 1 & Homog. test & $<40.2$ & $<39.7$ & $<39.95$ \\
\hline 33-8755 & \multirow[t]{3}{*}{$54: 1$} & Homog. test & $<40.6$ & $<40.8$ & $<40.7$ \\
\hline $41-8755$ & & Homog. test & $<40.4$ & $<40.7$ & $<40.55$ \\
\hline $40-8755$ & & Homog. test & $<40.9$ & $<40.9$ & $<40.9$ \\
\hline \multicolumn{3}{|c|}{ 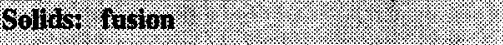 } & $\% \%$ & 4p/s. & 48 \\
\hline $25-6775$ & 53: 1 & Homog. test & 122 & 102 & 112 \\
\hline $33-6755$ & $54: 1$ & Homog. test & 39.3 & 52.7 & $46^{\mathrm{QC}: \mathrm{e}}$ \\
\hline \multicolumn{3}{|c|}{ 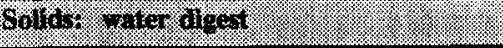 } & $1 \%$ & 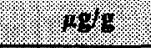 & 85 \\
\hline $25-7755$ & 53: 1 & Homog. test & $<6.99$ & $<6.97$ & $<6.98$ \\
\hline 33-7755 & $54: 1$ & Homog. test & $<42.1$ & $<42.1$ & $<42.1$ \\
\hline
\end{tabular}


Table B2-13. Tank 241-T-105 Analytical Results: Chromium (ICP).

\begin{tabular}{|c|c|c|c|c|c|}
\hline$\left(\frac{1}{4}\right)$ & 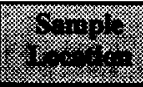 & 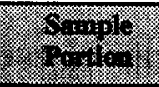 & $1 \%$ & 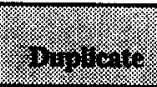 & $\%$ \\
\hline (6.) & (3) & 18 & (1) & (3) & $4 \%$ \\
\hline $25-8755$ & 53: 1 & Homog. test & 679 & 774 & 726.5 \\
\hline $33-8755$ & \multirow[t]{3}{*}{ 54: 1} & Homog. test & 285 & 283 & 284 \\
\hline $41-8755$ & & Homog. test & 277 & 267 & 272 \\
\hline $40-8755$ & & Homog. test & 241 & 275 & 258 \\
\hline \multicolumn{3}{|l|}{ 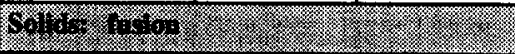 } & 6 & r. & $\% \%$ \\
\hline $25-6775$ & 53: 1 & Homog. test & 619 & 606 & 612.5 \\
\hline $33-6755$ & 54: 1 & Homog. test & 250 & 254 & 252 \\
\hline \multicolumn{3}{|c|}{$601 \%, 4,4 \%$} & $\%$ & 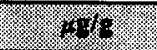 & 48 \\
\hline $25-7755$ & 53: 1 & Homog. test & 201 & 200 & $200.5^{\mathrm{OC}: \mathrm{b}}$ \\
\hline $33-7755$ & $54: 1$ & Homog. test & 94.3 & 96.3 & 95.3 \\
\hline
\end{tabular}

Table B2-14. Tank 241-T-105 Analytical Results: Iron (ICP).

\begin{tabular}{|c|c|c|c|c|c|}
\hline . & 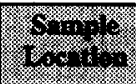 & 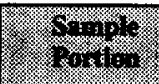 & (2) 1.0 & (4) & 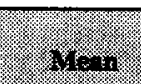 \\
\hline \multicolumn{2}{|c|}{ 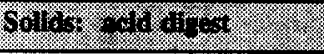 } & 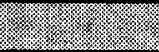 & $6 \%$ & 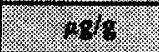 & 184 \\
\hline $25-8755$ & 53: 1 & Homog. test & 63,100 & 28,000 & $45,550^{\text {QC:d,e }}$ \\
\hline $33-8755$ & \multirow[t]{3}{*}{ 54: 1} & Homog. test & 9,700 & 8,470 & $9,085^{\text {QC:d }}$ \\
\hline $41-8755$ & & Homog. test & 8,020 & 26,400 & $17,210^{Q C ; e}$ \\
\hline $40-8755$ & & Homog. test & 12,700 & 11,400 & 12,050 \\
\hline \multicolumn{2}{|c|}{ 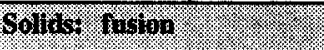 } & & 19 & $89 \%$ & 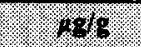 \\
\hline $25-6775$ & 53: 1 & Homog. test & 33,700 & 47,500 & $40,600^{\mathrm{oc}: d, e}$ \\
\hline $33-6755$ & 54: 1 & Homog. test & 25,000 & 26,000 & 25,500 \\
\hline \multicolumn{3}{|c|}{ 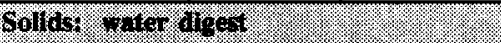 } & 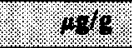 & 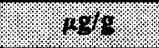 & $6 \%$ \\
\hline $25-7755$ & 53: 1 & Homog. test & 2.01 & 3.28 & $2.645^{\mathrm{QC}: \mathrm{e}}$ \\
\hline $33-7755$ & 54: 1 & Homog. test & 16.8 & 19.6 & 18.2 \\
\hline
\end{tabular}


Table B2-15. Tank 241-T-105 Analytical Results: Lanthanum (ICP).

\begin{tabular}{|c|c|c|c|c|c|}
\hline 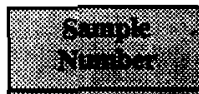 & (2) & (3) & 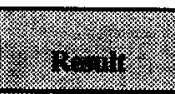 & 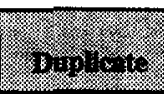 & 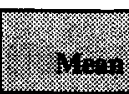 \\
\hline \multicolumn{3}{|c|}{ 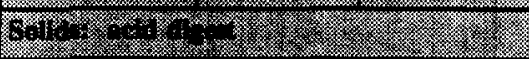 } & 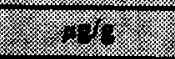 & 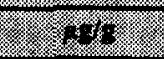 & (3) \\
\hline $25-8755$ & $53: 1$ & Homog. test & 16.8 & 31.9 & $24.35^{\mathrm{QC}: \mathrm{e}}$ \\
\hline $33-8755$ & \multirow[t]{3}{*}{ 54: 1} & Homog. test & $<15.9$ & $<15.9$ & $<15.9$ \\
\hline $41-8755$ & & Homog. test & $<15.7$ & $<15.9$ & $<15.8$ \\
\hline $40-8755$ & & Homog. test & $<16$ & $<16$ & $<16$ \\
\hline 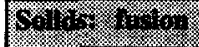 & 2) & ) & (3) & (n) & (-) 10 \\
\hline $25-6775$ & 53: 1 & Homog. test & $<8.37$ & $<8.4$ & $<8.385$ \\
\hline $33-6755$ & 54: 1 & Homog. test & $<8.47$ & $<8.33$ & $<8.4$ \\
\hline $68(1 \%+2)+1$ & $1+3$ & & \% & (3) 10 & 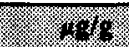 \\
\hline $25-7755$ & 53: 1 & Homog. test & $<1.75$ & $<1.74$ & $<1.745$ \\
\hline $33-7755$ & 54: 1 & Homog. test & $<16.4$ & $<16.4$ & $<16.4$ \\
\hline
\end{tabular}

Table B2-16. Tank 241-T-105 Analytical Results: Lead (ICP).

\begin{tabular}{|c|c|c|c|c|c|}
\hline$\left(\frac{9}{4}\right.$ & Somplo & Simpirs. & 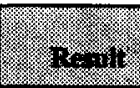 & Buplowe & $9=$ \\
\hline \multicolumn{3}{|c|}{ 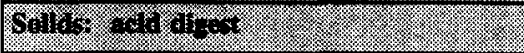 } & 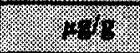 & . & 34 \\
\hline $25-8755$ & 53: 1 & Homog. test & 859 & 739 & 799 \\
\hline 33-8755 & \multirow[t]{3}{*}{ 54: 1} & Homog. test & 302 & 236 & $269^{Q C: e}$ \\
\hline 41-8755 & & Homog. test & 196 & 396 & $296^{\mathrm{QC}: \mathrm{e}}$ \\
\hline $40-8755$ & & Homog. test & 320 & 211 & $265.5^{\mathrm{QC}: \mathrm{e}}$ \\
\hline \multicolumn{3}{|l|}{ Solits rifling } & $4 \% 8$ & 18014 & 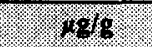 \\
\hline $25-6775$ & 53: 1 & Homog. test & 630 & 578 & 604 \\
\hline $33-6755$ & 54: 1 & Homog. test & 326 & 277 & 301.5 \\
\hline \multicolumn{3}{|c|}{ 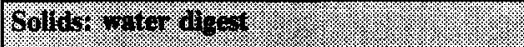 } & 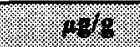 & (1) & :. \\
\hline $25-7755$ & 53: 1 & Homog. test & $<6.37$ & 10 & $<8.185^{\mathrm{QC:e}}$ \\
\hline 33-7755 & 54: 1 & Homog. test & $<39$ & 48.3 & $<43.65^{\mathrm{QC:e}}$ \\
\hline
\end{tabular}


HNF-SD-WM-ER-369 Rev. 1

Table B2-17. Tank 241-T-105 Analytical Results: Lithium (ICP).

\begin{tabular}{|c|c|c|c|c|c|}
\hline$\left(\frac{1}{4}\right)$ & 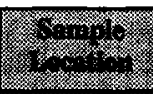 & $\frac{10}{80}$ & 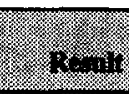 & B & 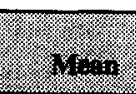 \\
\hline $3 \%$ & 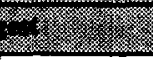 & 20 & 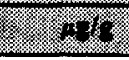 & $7.8 \%$ & 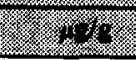 \\
\hline $25-8755$ & 53: 1 & Homog. test & 4.87 & $<3.87$ & $<4.37^{\alpha \mathrm{C}: \mathrm{e}}$ \\
\hline $33-8755$ & \multirow[t]{3}{*}{ 54: 1} & Homog. test & $<3.96$ & 4.18 & $<4.07$ \\
\hline $41-8755$ & & Homog. test & $<3.94$ & 5.32 & $<4.63^{\mathrm{QC:c}}$ \\
\hline $40-8755$ & & Homog. test & $<3.99$ & $<3.99$ & $<3.99$ \\
\hline 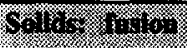 & $8>$ & & (2) & (1) & \% \\
\hline $25-6775$ & 53: 1 & Homog. test & 4.16 & 4.32 & 4.24 \\
\hline $33-6755$ & $54: 1$ & Homog. test & 2.37 & 3.51 & $2.94^{Q C: c}$ \\
\hline 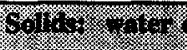 & 124 & & 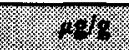 & 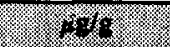 & 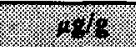 \\
\hline $25-7755$ & 53: 1 & Homog. test & $<0.411$ & $<0.41$ & $<0.4105$ \\
\hline $33-7755$ & 54: 1 & Homog. test & $<4.1$ & $<4.11$ & $<4.105$ \\
\hline
\end{tabular}

Table B2-18. Tank 241-T-105 Analytical Results: Magnesium (ICP).

\begin{tabular}{|c|c|c|c|c|c|}
\hline . & 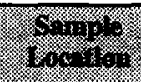 & 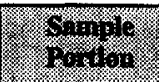 & . & 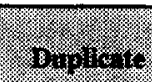 & $\sqrt{17}$ \\
\hline \multicolumn{3}{|c|}{601960.010} & (2) & 1848 & ive \\
\hline $25-8755$ & $53: 1$ & Homog. test & 935 & 1,120 & $1,027.5$ \\
\hline $33-8755$ & \multirow[t]{3}{*}{ 54: 1} & Homog. test & 1,070 & 1,130 & 1,100 \\
\hline $41-8755$ & & Homog. test & 1,110 & 1,060 & $1,085^{\mathrm{QC:b}}$ \\
\hline $40-8755$ & & Homog. test & 959 & 1,040 & 999.5 \\
\hline \multicolumn{3}{|l|}{ 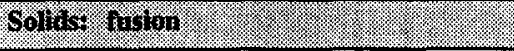 } & 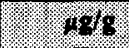 & 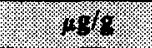 & 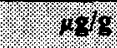 \\
\hline $25-6775$ & 53: 1 & Homog. test & 1,220 & 1,280 & 1,250 \\
\hline $33-6755$ & 54: 1 & Homog. test & 997 & 918 & 957.5 \\
\hline \multicolumn{3}{|c|}{ Goliost rollor diger } & 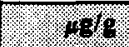 & 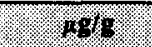 & .868 \\
\hline $25-7755$ & 53: 1 & Homog. test & 6.23 & 6.56 & 6.395 \\
\hline $33-7755$ & 54: 1 & Homog. test & 19.8 & 25 & $22.4^{\mathrm{QC}: \mathrm{c}}$ \\
\hline
\end{tabular}


Table B2-19. Tank 241-T-105 Analytical Results: Manganese (ICP).

\begin{tabular}{|c|c|c|c|c|c|}
\hline 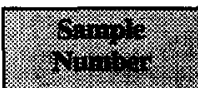 & (2) & 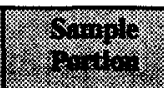 & 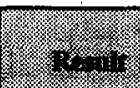 & 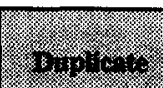 & 10 \\
\hline \multicolumn{3}{|c|}{ 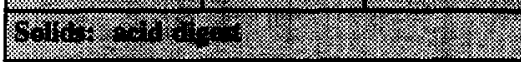 } & (2) & $28 \%$ & $\sqrt{13}$ \\
\hline $25-8755$ & 53: 1 & Homog. test & 17,900 & 21,800 & $19,850^{\mathrm{oc}: \mathrm{d}}$ \\
\hline $33-8755$ & \multirow[t]{3}{*}{ 54: 1} & Homog. test & 3,400 & 3,250 & 3,325 \\
\hline 41-8755 & & Homog. test & 3,030 & 3,070 & 3,050 \\
\hline $40-8755$ & & Homog. test & 2,970 & 2,830 & 2,900 \\
\hline Ginis, $101 \%$ & 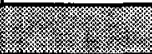 & & $2.87 \%$ & 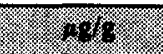 & 18 \\
\hline $25-6775$ & $53: 1$ & Homog. test & 18,000 & 17,800 & $17,900^{0 \mathrm{cc}: \mathrm{d}}$ \\
\hline $33-6755$ & 54: 1 & Homog. test & 3,190 & 2,420 & $2,805^{Q C: d, e}$ \\
\hline \multicolumn{3}{|c|}{ 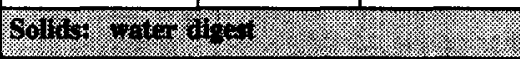 } & ?. & $148 \%$ & 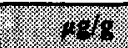 \\
\hline $25-7755$ & 53: 1 & Homog. test & 0.783 & 0.936 & 0.8595 \\
\hline $33-7755$ & 54: 1 & Homog. test & $<3.08$ & $<3.08$ & $<3.08$ \\
\hline
\end{tabular}

Table B2-20. Tank 241-T-105 Analytical Results: Molybdenum (ICP).

\begin{tabular}{|c|c|c|c|c|c|}
\hline ( & 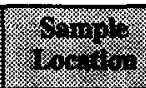 & 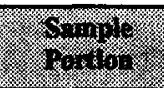 & $\left(x_{x}+1\right)$ & 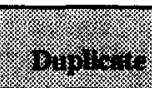 & 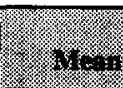 \\
\hline \multicolumn{2}{|c|}{ Soll $=9 \% 1 \%$} & 8 & 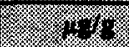 & 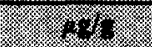 & (3) 1914 \\
\hline $25-8755$ & 53: 1 & Homog. test & 38.1 & 43.3 & 40.7 \\
\hline $33-8755$ & \multirow[t]{3}{*}{ 54: 1} & Homog. test & 28.3 & 27.5 & 27.9 \\
\hline $41-8755$ & & Homog, test & 20.4 & 23 & 21.7 \\
\hline $40-8755$ & & Homog. test & 20.6 & 24.8 & 22.7 \\
\hline Sollast linion & צ: & 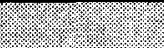 & . & 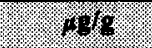 & $18 \% 8$ \\
\hline $25-6775$ & 53: 1 & Homog. test & 37.2 & 41.8 & 39.5 \\
\hline $33-6755$ & 54: 1 & Homog. test & 23.7 & 23.9 & 23.8 \\
\hline \multicolumn{3}{|c|}{ 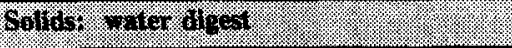 } & . .104 & .848 & . $48 \mathrm{c}$ \\
\hline $25-7755$ & $53: 1$ & Homog. test & 47.5 & 47.9 & 47.7 \\
\hline $33-7755$ & 54: 1 & Homog. test & 21.3 & 22.1 & 21.7 \\
\hline
\end{tabular}


Table B2-21. Tank 241-T-105 Analytical Results: Neodymium (ICP).

\begin{tabular}{|c|c|c|c|c|c|}
\hline 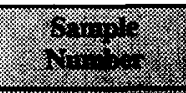 & (2) & -6 & 2.0 & 1 & (2) \\
\hline 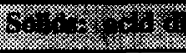 & 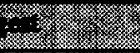 & 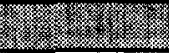 & $=2.1 \%$ & 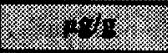 & 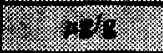 \\
\hline $25-8755$ & 53: 1 & Homog. test & 159 & 145 & 152 \\
\hline $33-8755$ & \multirow[t]{3}{*}{ 54: 1} & Homog. test & $<59.5$ & $<59.7$ & $<59.6$ \\
\hline $41-8755$ & & Homog. test & $<59.1$ & 73.4 & $<66.25^{\text {QC:e }}$ \\
\hline $40-8755$ & & Homog, test & $<59.9$ & $<59.9$ & $<59.9$ \\
\hline Oof & \multicolumn{2}{|c|}{$(-3)-(-2)$} & $8.18 \%$ & 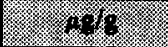 & 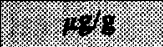 \\
\hline $25-6775$ & 53: 1 & Homog. test & 96.1 & 124 & $110.05^{\mathrm{OC:e}}$ \\
\hline $33-6755$ & 54: 1 & Homog. test & $<40.8$ & 40.6 & $<40.7$ \\
\hline \multicolumn{2}{|c|}{ 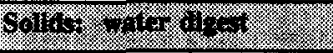 } & 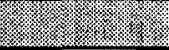 & 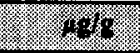 & 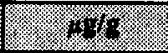 & $2=84$ \\
\hline $25-7755$ & 53: 1 & Homog. test & $<8.43$ & $<8.41$ & $<8.42$ \\
\hline $33-7755$ & 54: 1 & Homog. test & $<61.5$ & $<61.6$ & $<61.55$ \\
\hline
\end{tabular}

Table B2-22. Tank 241-T-105 Analytical Results: Nickel (ICP).

\begin{tabular}{|c|c|c|c|c|c|}
\hline 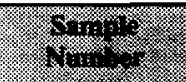 & 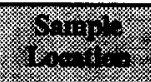 & 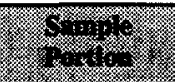 & 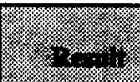 & 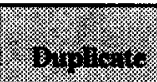 & 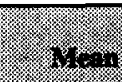 \\
\hline \multicolumn{2}{|c|}{ Gerlis } & (2) & (3) & 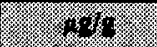 & 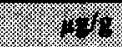 \\
\hline $25-8755$ & 53: 1 & Homog. test & 91.1 & 102 & 96.55 \\
\hline $33-8755$ & \multirow[t]{3}{*}{ 54: 1} & Homog. test & 64.5 & 67.6 & 66.05 \\
\hline $41-8755$ & & Homog. test & 63.7 & 71.8 & 67.75 \\
\hline $40-8755$ & & Homog. test & 56.7 & 56.9 & 56.8 \\
\hline \multicolumn{2}{|c|}{ 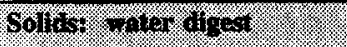 } & (2) & 4.96 & 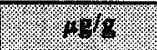 & 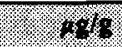 \\
\hline $25-7755$ & 53: 1 & Homog. test & 13.8 & 14 & 13.9 \\
\hline $33-7755$ & 54: 1 & Homog. test & 11.5 & $<11.3$ & $<11.4$ \\
\hline
\end{tabular}


HNF-SD-WM-ER-369 Rev. 1

Table B2-23. Tank 241-T-105 Analytical Results: Phosphorus (ICP).

\begin{tabular}{|c|c|c|c|c|c|}
\hline$\sqrt{2.013}$ & 格 & $f_{1}$ & 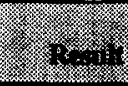 & 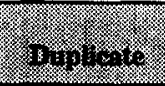 & $\sqrt{2}+4$ \\
\hline \multicolumn{3}{|c|}{ Kory } & (1) & (x) & 4 \\
\hline $25-8755$ & 53: 1 & Homog. test & 1,710 & 1,900 & 1,805 \\
\hline $33-8755$ & \multirow[t]{3}{*}{$54: 1$} & Homog. test & 1,210 & 1,150 & 1,180 \\
\hline $41-8755$ & & Homog. test & 1,140 & 1,130 & 1,135 \\
\hline $40-8755$ & & Homog. test & 976 & 1,180 & $1,078^{\mathrm{eC}: \mathrm{d}}$ \\
\hline \multicolumn{3}{|c|}{ 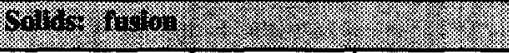 } & 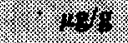 & $84 \%$ & 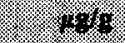 \\
\hline $25-6775$ & $53: 1$ & Homog. test & 1,910 & 2,000 & 1,955 \\
\hline $33-6755$ & 54: 1 & Homog. test & 1,160 & 1,060 & 1,110 \\
\hline \multicolumn{2}{|c|}{ 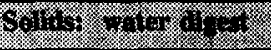 } & & 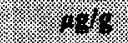 & 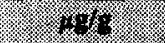 & 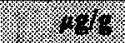 \\
\hline $25-7755$ & 53: 1 & Homog. test & 911 & 871 & 891 \\
\hline 33.7755 & 54: 1 & Homog. test & 314 & 523 & $418.5^{\mathrm{QC}: \mathrm{d}, \mathrm{e}}$ \\
\hline
\end{tabular}

Table B2-24. Tank 241-T-105 Analytical Results: Potassium (ICP).

\begin{tabular}{|c|c|c|c|c|c|}
\hline 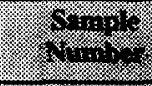 & (2) & 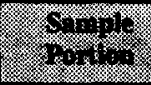 & $1 \%$ & 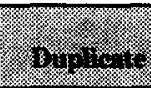 & 4 \\
\hline \multicolumn{3}{|c|}{ 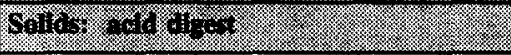 } & $4 \%$ & 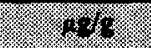 & (2) \\
\hline $25-8755$ & 53: 1 & Homog. test & 346 & 449 & $397.5^{\text {QCin,e }}$ \\
\hline $33-8755$ & \multirow[t]{3}{*}{ 54: 1} & Homog. test & 234 & 191 & 212.5 \\
\hline $41-8755$ & & Homog. test & 210 & 155 & $182.5^{\mathrm{QC:A,e}}$ \\
\hline $40-8755$ & & Homog, test & 231 & 276 & 253.5 \\
\hline \multicolumn{2}{|c|}{ 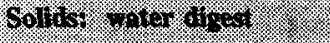 } & & 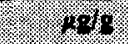 & 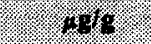 & 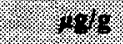 \\
\hline $25-7755$ & 53: 1 & Homog. test & 369 & 377 & 373 \\
\hline $33-7755$ & $54: 1$ & Homog, test & 237 & 121 & $179^{\mathrm{QC}: \mathrm{e}}$ \\
\hline
\end{tabular}


Table B2-25. Tank 241-T-105 Analytical Results: Samarium (ICP).

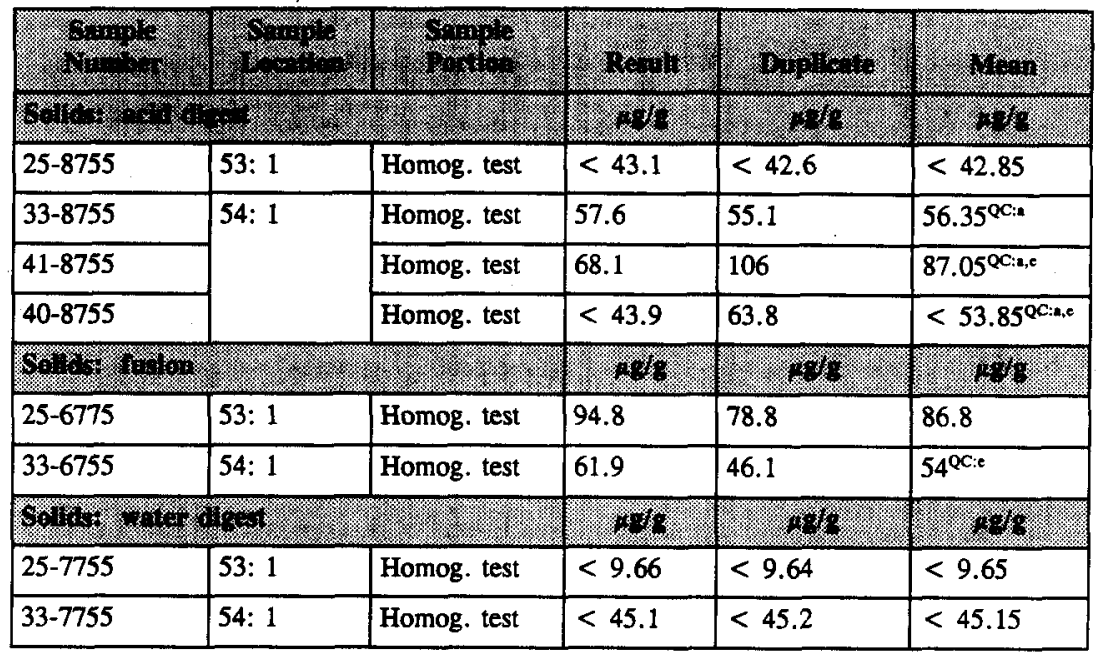

Table B2-26. Tank 241-T-105 Analytical Results: Selenium (ICP).

\begin{tabular}{|c|c|c|c|c|c|}
\hline (3) & (6.) & 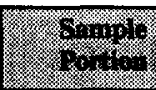 & (3) & $\left(\frac{1}{4}\right.$ & $4 \log n$ \\
\hline \multicolumn{2}{|c|}{ (4) } & স ২: & 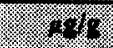 & (2) & (2. \\
\hline $25-8755$ & 53: 1 & Homog. test & $<61.8$ & $<60.9$ & $<61.35^{\mathrm{QC}: \mathrm{a}, \mathrm{c}}$ \\
\hline $33-8755$ & \multirow[t]{3}{*}{$54: 1$} & Homog. test & $<62.4$ & $<62.7$ & $<62.55^{Q C: A, c}$ \\
\hline $41-8755$ & & Homog, test & $<62$ & $<62.6$ & $<62.3^{\mathrm{OC}: \mathrm{a}, \mathrm{c}}$ \\
\hline $40-8755$ & & Homog. test & $<62.9$ & $<62.9$ & $<62.9^{\mathrm{QC}: \mathrm{n}, \mathrm{c}}$ \\
\hline 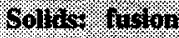 & & & 18 & 8,15 & $4 \%$ \\
\hline $25-6775$ & $53: 1$ & Homog. test & $<42.8$ & $<43$ & $<42.9^{\mathrm{QC}: \mathrm{c}}$ \\
\hline $33-6755$ & 54: 1 & Homog. test & $<43.3$ & $<42.6$ & $<42.95$ \\
\hline \multicolumn{2}{|c|}{ 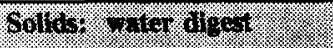 } & & 18 & $1 \%$ & 1808 \\
\hline $25-7755$ & 53: 1 & Homog. test & $<8.94$ & $<8.92$ & $<8.93^{\mathrm{OC}: \mathrm{c}}$ \\
\hline $33-7755$ & 54: 1 & Homog. test & $<64.6$ & 74.7 & $<69.65^{\mathrm{QC}: \mathbf{a}, \mathrm{c}}$ \\
\hline
\end{tabular}


Table B2-27. Tank 241-T-105 Analytical Results: Silicon (ICP).

\begin{tabular}{|c|c|c|c|c|c|}
\hline (3) & ( & 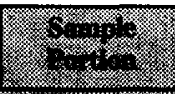 & (2) & 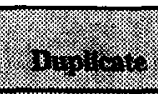 & 46 \\
\hline 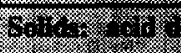 & 1 & $\sqrt{16}$ & 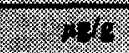 & 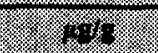 & (3) \\
\hline $25-8755$ & 53: 1 & Homog. test & 2,380 & 2,120 & $2,250^{\mathrm{QC:b}}$ \\
\hline 33-8755 & \multirow[t]{3}{*}{ 54: 1} & Homog. test & 90 & 54.9 & $72.45^{\mathrm{QC}: b, e}$ \\
\hline $41-8755$ & & Homog. test & 243 & 332 & $287.5^{\text {QC:bee }}$ \\
\hline $40-8755$ & & Homog. test & 216 & 244 & $230^{\circ \mathrm{C}: \mathrm{b}}$ \\
\hline SWmo, = & -8 & () & \% & 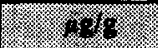 & 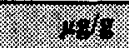 \\
\hline $25-6775$ & 53: 1 & Homog. test & 6,420 & 9,110 & $7,765^{\mathrm{QC}: e}$ \\
\hline $33-6755$ & $54: 1$ & Homog. test & 6,640 & 5,760 & 6,200 \\
\hline \multicolumn{2}{|c|}{ 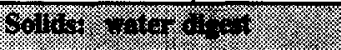 } & 20 & 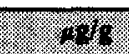 & $19 \%$ & 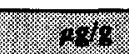 \\
\hline $25-7755$ & 53: 1 & Homog. test & 514 & 466 & $490^{\mathrm{QC}: d}$ \\
\hline $33-7755$ & $54: 1$ & Homog. test & 946 & 1,060 & $1,003^{\mathrm{oC}: \mathrm{b}, \mathrm{d}}$ \\
\hline
\end{tabular}

Table B2-28. Tank 241-T-105 Analytical Results: Silver (ICP).

\begin{tabular}{|c|c|c|c|c|c|}
\hline 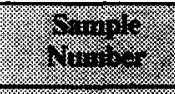 & 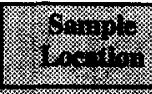 & 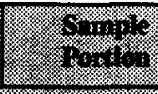 & 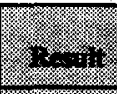 & 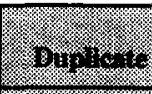 & 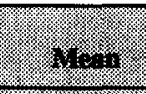 \\
\hline \multicolumn{2}{|c|}{ 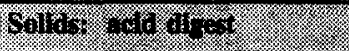 } & 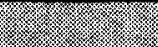 & 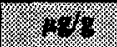 & (3. & $18 \%$ \\
\hline $25-8755$ & 53: 1 & Homog. test & 9.96 & 16.9 & $13.43^{\mathrm{OC}: \mathrm{n}, \mathrm{e}}$ \\
\hline $33-8755$ & \multirow[t]{3}{*}{ 54: 1} & Homog. test & 20.1 & 19.5 & $19.8^{\text {QC:s,c }}$ \\
\hline $41-8755$ & & Homog. test & 21.6 & 16.2 & $18.9^{\mathrm{QC}: \mathrm{a}, \mathrm{e}}$ \\
\hline $40-8755$ & & Homog. test & 17.8 & 20.2 & $19^{\mathrm{QC}: \mathrm{A}}$ \\
\hline \multicolumn{2}{|l|}{ Soldtry inown } & (8) & $1 \%$ & (1) 104 & 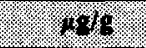 \\
\hline $25-6775$ & 53:1 & Homog. test & 66.4 & 72.2 & 69.3 \\
\hline $33-6755$ & 54: 1 & Homog. test & 25.9 & 20.3 & $23.1^{\text {QC:c }}$ \\
\hline \multicolumn{3}{|c|}{ 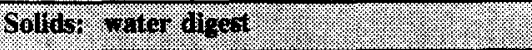 } & 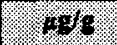 & . & 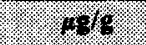 \\
\hline $25-7755$ & 53: 1 & Homog. test & 4.89 & 5.43 & 5.16 \\
\hline $33-7755$ & 54: 1 & Homog. test & $<6.15$ & $<6.16$ & $<6.155^{\mathrm{QC}: \mathrm{c}}$ \\
\hline
\end{tabular}


Table B2-29. Tank 241-T-105 Analytical Results: Sodium (ICP).

\begin{tabular}{|c|c|c|c|c|c|}
\hline (2) & (2) & 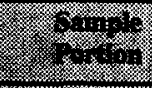 & 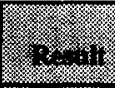 & 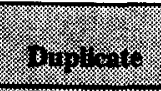 & 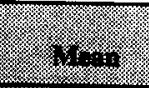 \\
\hline \multicolumn{3}{|c|}{ 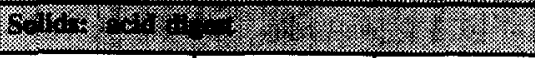 } & 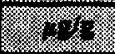 & (1) & \%, \\
\hline $25-8755$ & 53: 1 & Homog. test & 63,300 & 73,900 & $68,600^{9 C: b, d}$ \\
\hline $33-8755$ & \multirow[t]{3}{*}{ 54: 1} & Homog. test & 44,900 & 43,200 & $44,050^{\mathrm{CC}: \mathrm{b}, \mathrm{d}}$ \\
\hline $41-8755$ & & Homog. test & 43,200 & 41,700 & $42,450^{Q \mathrm{CC}: b, d}$ \\
\hline $40-8755$ & & Homog. test & 38,900 & 41,400 & $40,150^{\text {QC:b,d }}$ \\
\hline \multicolumn{2}{|c|}{ 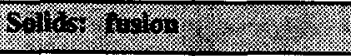 } & & $18 \%$ & .818 & 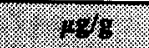 \\
\hline $25-6775$ & 53: 1 & Homog. test & 61,400 & 62,800 & $62,100^{\mathrm{ec:d}}$ \\
\hline $33-6755$ & 54: 1 & Homog. test & 40,800 & 31,800 & $36,300^{Q C: d, e}$ \\
\hline \multicolumn{2}{|c|}{ 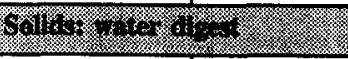 } & & 4.18 & 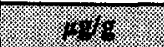 & 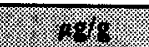 \\
\hline $25-7755$ & 53: 1 & Homog. test & 60,300 & 60,800 & $60,550^{\mathrm{oC:d}}$ \\
\hline $33-7755$ & 54: 1 & Homog. test & 37,500 & 39,200 & $38,350^{\mathrm{Qc:c}}$ \\
\hline
\end{tabular}

Table B2-30. Tank 241-T-105 Analytical Results: Strontium (ICP).

\begin{tabular}{|c|c|c|c|c|c|}
\hline singory & 9.9.7) & 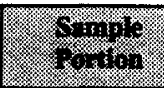 & 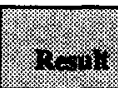 & 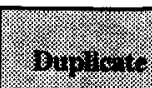 & 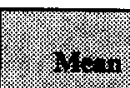 \\
\hline \multicolumn{2}{|c|}{ 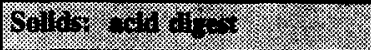 } & 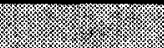 & is: & 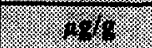 & 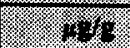 \\
\hline 25 & 53: 1 & Homog. test & 121 & 136 & 128.5 \\
\hline $33-8755$ & \multirow[t]{3}{*}{ 54: 1} & Homog. test & 163 & 170 & 166.5 \\
\hline $41-8755$ & & Homog. test & 166 & 163 & 164.5 \\
\hline $40-8755$ & & Homog. test & 152 & 159 & 155.5 \\
\hline Sollos, rnoron & & & 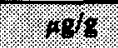 & 3.64 & 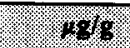 \\
\hline $25-6775$ & 53: 1 & Homog. test & 126 & 133 & 129.5 \\
\hline $33-6755$ & 54: 1 & Homog. test & 161 & 145 & 153 \\
\hline Solfor . & 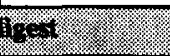 & (2) & 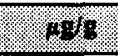 & 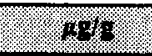 & 400 \\
\hline $25-7755$ & 53: 1 & Homog. test & 0.917 & 1.04 & 0.9785 \\
\hline $33-7755$ & 54: 1 & Homog. test & $<3.08$ & $<3.08$ & $<3.08$ \\
\hline
\end{tabular}


Table B2-31. Tank 241-T-105 Analytical Results: Sulfur (ICP).

\begin{tabular}{|c|c|c|c|c|c|}
\hline 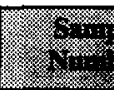 & $3^{2}$ & 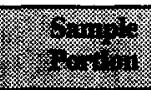 & 咩 & 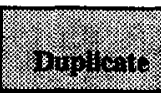 & (2) \\
\hline (9) & (1) & 济 & (3) & (2) & r. \\
\hline $25-8755$ & 53: 1 & Homog. test & 2,990 & 3,630 & $3,310^{9 \mathrm{C}: \mathrm{b}}$ \\
\hline $33-8755$ & \multirow[t]{3}{*}{ 54: 1} & Homog. test & 1,940 & 1,860 & 1,900 \\
\hline $41-8755$ & & Homog. test & 1,970 & 1,860 & $1,915^{Q C: b}$ \\
\hline $40-8755$ & & Homog. test & 1,620 & 1,830 & $1,725^{\mathrm{QC:b}}$ \\
\hline \multicolumn{3}{|c|}{ 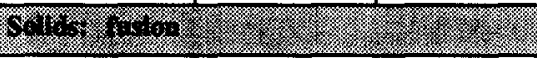 } & 渻 & (x) & 8 \\
\hline $25-6775$ & 53: 1 & Homog. test & 3,370 & 3,570 & 3,470 \\
\hline $33-6755$ & 54: 1 & Homog. test & 1,830 & 1,710 & 1,770 \\
\hline \multicolumn{3}{|c|}{ (b) } & $4 \%$ & 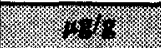 & (3. - \\
\hline $25-7755$ & 53: 1 & Hómog. test & 3,450 & 3,460 & $3,455^{\mathrm{QC}: \mathrm{d}}$ \\
\hline $33-7755$ & 54: 1 & Homog. test & 1,950 & 2,160 & 2,055 \\
\hline
\end{tabular}

Table B2-32. Tank 241-T-105 Analytical Results: Thallium (ICP).

\begin{tabular}{|c|c|c|c|c|c|}
\hline 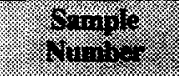 & 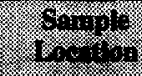 & 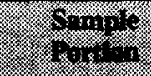 & $(2,1)$ & $8+1,4=$ & $4 \%$ \\
\hline \multicolumn{2}{|c|}{ 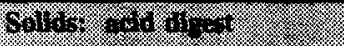 } & & $(x, 3)$ & $8 \%$ & $8 \%$ \\
\hline $25-8755$ & 53: 1 & Homog. test & $<79.4$ & $<78.3$ & $<78.85^{\mathrm{QC}: \mathrm{a}}$ \\
\hline $33-8755$ & \multirow[t]{3}{*}{$54: 1$} & Homog. test & 97.8 & 104 & $100.9^{\mathrm{QC:A,c}}$ \\
\hline 41-8755 & & Homog. test & $<79.7$ & $<80.4$ & $<80.05^{\propto C: \mathrm{A}}$ \\
\hline $40-8755$ & & Homog. test & 91.9 & $<80.8$ & $<86.35$ \\
\hline \multicolumn{3}{|l|}{ 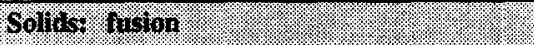 } & 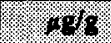 & $18 \%$ & - \\
\hline $25-6775$ & 53: 1 & Homog. test & $<80.7$ & $<81$ & $<80.85$ \\
\hline $33-6755$ & 54: 1 & Homog. test & $<81.7$ & $<80.4$ & $<81.05$ \\
\hline \multicolumn{3}{|c|}{ 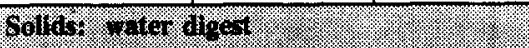 } & 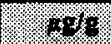 & 4015 & 1040 \\
\hline $25-7755$ & 53: 1 & Homog. test & $<16.9$ & $<16.8$ & $<16.85$ \\
\hline $33-7755$ & 54: 1 & Homog. test & $<83.1$ & $<83.2$ & $<83.15$ \\
\hline
\end{tabular}


HNF-SD-WM-ER-369 Rev. 1

Tabie B2-33. Tank 241-T-105 Analytical Results: Titanium (ICP).

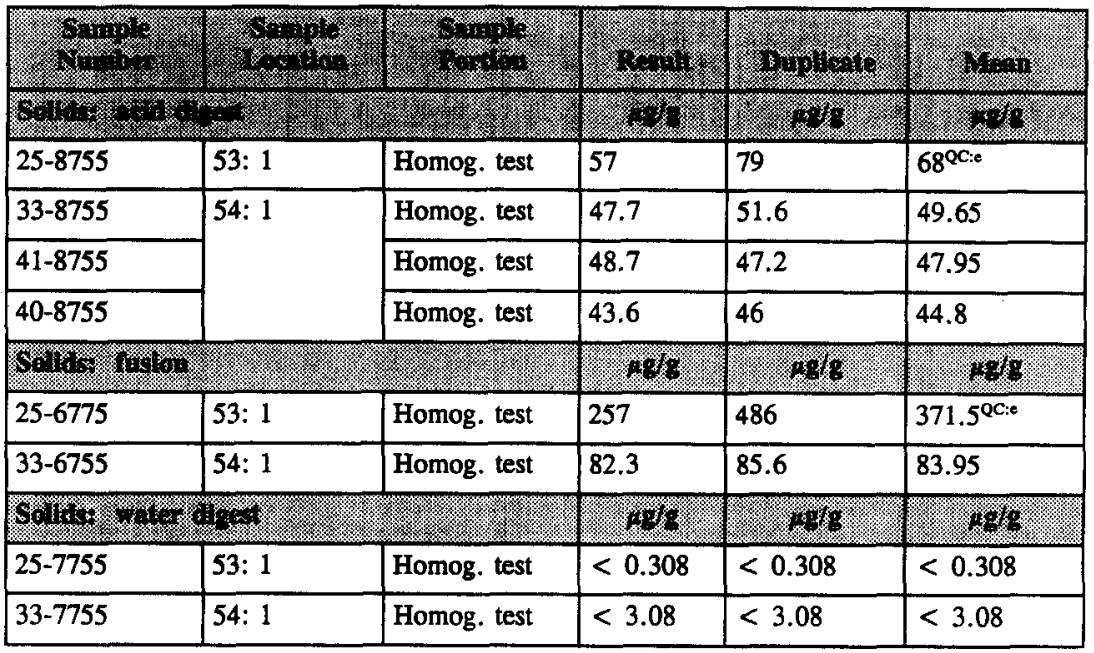

Table B2-34. Tank 241-T-105 Analytical Results: Zirconium (ICP).

\begin{tabular}{|c|c|c|c|c|c|}
\hline 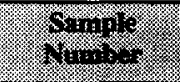 & ( & 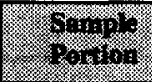 & $4=1$ & 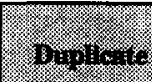 & lat. \\
\hline \multicolumn{3}{|c|}{ 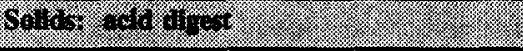 } & $11 \%$ & 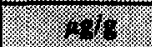 & 20 \\
\hline $25-8755$ & 53: 1 & Homog. test & 89.9 & 87.9 & 88.9 \\
\hline $33-8755$ & \multirow[t]{3}{*}{ 54: 1} & Homog. test & $<14.4$ & 11.1 & $<12.75^{\mathrm{QC}: \mathrm{e}}$ \\
\hline $41-8755$ & & Homog. test & 17.1 & 78.4 & $47.75^{\mathrm{eC}: e}$ \\
\hline $40-8755$ & & Homog. test & 73.5 & 74 & 73.75 \\
\hline Sollist insion & 0. & & $1.98 \mathrm{~g}$ & .1968 & .409 \\
\hline $25-6775$ & 53: 1 & Homog. test & 176 & 115 & $145.5^{\mathrm{QC}: \mathrm{e}}$ \\
\hline $33-6755$ & 54: 1 & Homog. test & 99.8 & 83.5 & 91.65 \\
\hline \multicolumn{3}{|c|}{ 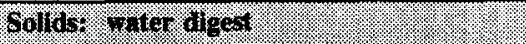 } & 19814 & 1018 & 496 \\
\hline $25-7755$ & 53: 1 & Homog. test & $<0.719$ & $<0.718$ & $<0.7185$ \\
\hline $33-7755$ & $54: 1$ & Homog. test & $<6.15$ & $<6.16$ & $<6.155$ \\
\hline
\end{tabular}


Table B2-35. Tank 241-T-105 Analytical Results: Total Uranium (Laser Fluorimetry).

\begin{tabular}{|c|c|c|c|c|c|}
\hline$x^{2}$ & (2) & 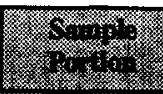 & 3. & 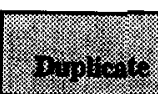 & 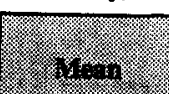 \\
\hline 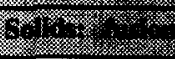 & (2) & $l^{2}$ & 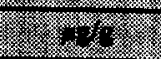 & 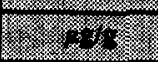 & 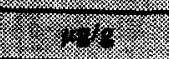 \\
\hline $25-6740$ & 53: 2 & Homog. test & 8,390 & 9,090 & 8,740 \\
\hline $33-6740$ & 54: 1 & Homog. test & 10,200 & 8,880 & 9,540 \\
\hline rogro. & 3 & . & 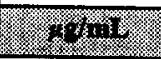 & $4 \% \mathrm{ml}$ & 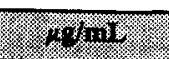 \\
\hline $19-5740$ & $53: 2$ & Homog. test & 8.48 & 7.02 & $7.75^{\mathrm{OC}: \mathrm{c}}$ \\
\hline
\end{tabular}

Table B2-36. Tank 241-T-105 Analytical Results: Hexavalent Chromium ( $\mathrm{Cr}+6)$.

\begin{tabular}{|c|c|c|c|c|c|}
\hline$x_{1}+x_{1}$ & (2) & 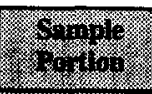 & 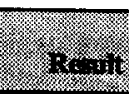 & $8,1310.0 .10$ & (2. \\
\hline 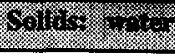 & 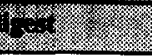 & & 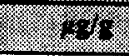 & 4 & $1 \%$ \\
\hline $25-7769$ & 53: 1 & Homog. test & $<18.3$ & $<18.3$ & $<18.3$ \\
\hline $33-7769$ & $54: 1$ & Homog. test & $<18.3$ & $<18.3$ & $<18.3$ \\
\hline
\end{tabular}

Table B2-37. Tank 241-T-105 Analytical Results: Ammonium (Distillation).

\begin{tabular}{|c|c|c|c|c|c|}
\hline 10 & 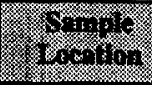 & 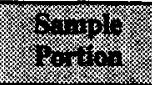 & inosin: & 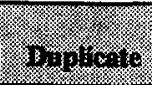 & rils n \\
\hline ofolder 120, & $3=$ & & 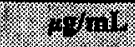 & $10 \% 1 \% 1$ & \%.rin \\
\hline $33-7728$ & 54:1 & Homog. test & $<20$ & $<20$ & $<20$ \\
\hline Wratus & 8 & (-2) & $1 \% \%$ & 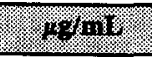 & $4.4 \%$ \\
\hline $19-5728$ & 53: 2 & Homog. test & $<400$ & $<400$ & $<400$ \\
\hline
\end{tabular}


HNF-SD-WM-ER-369 Rev. 1

Table B2-38. Tank 241-T-105 Analytical Results: pH Measurement (pH).

\begin{tabular}{|c|c|c|c|c|c|}
\hline$\sqrt{8}$ & $3^{2}+9$ & 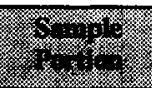 & 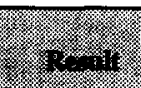 & 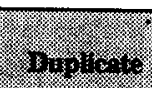 & $\sqrt{1}$ \\
\hline 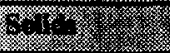 & (2) & - & 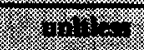 & 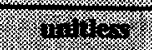 & 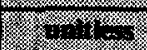 \\
\hline $25-5715$ & \multirow[t]{2}{*}{ 54: 1} & Homog. test & 11.31 & 11.27 & 11.29 \\
\hline $33-5715$ & & Homog. test & 12.05 & 12.07 & 12.06 \\
\hline 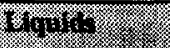 & 20 & 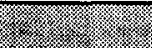 & renitess & ingin & 8,130160 \\
\hline $19-5713$ & 53: 2 & Homog. test & 12 & 12.01 & 12.005 \\
\hline $22-5713$ & $54: 2$ & Homog. test & 8.26 & 8.29 & 8.275 \\
\hline
\end{tabular}

Table B2-39. Tank 241-T-105 Analytical Results: Chloride (IC).

\begin{tabular}{|c|c|c|c|c|c|}
\hline 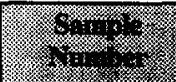 & 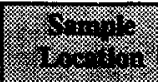 & 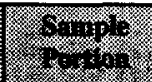 & 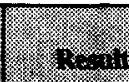 & 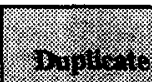 & $1 \%$ \\
\hline \multicolumn{3}{|c|}{ 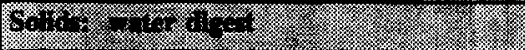 } & 2.10 & 19 & 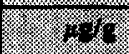 \\
\hline $25-7771$ & 53: 1 & Homog. test & 504 & 517 & 510.5 \\
\hline $33-7771$ & 54: 1 & Homog. test & 293 & 294 & 293.5 \\
\hline 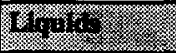 & (2) & - & 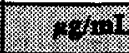 & (2) & 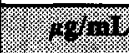 \\
\hline $19-5771$ & 53: 2 & Homog. test & 226 & 232 & 229 \\
\hline $22-5771$ & 54: 2 & Homog. test & 8.54 & 9.06 & 8.8 \\
\hline
\end{tabular}

Table B2-40. Tank 241-T-105 Analytical Results: Fluoride (IC).

\begin{tabular}{|c|c|c|c|c|c|}
\hline$\frac{4}{40+10}$ & 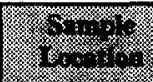 & 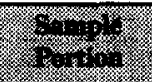 & 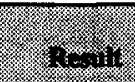 & 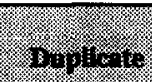 & $4 \%$ \\
\hline Wrates & (2) & (2) & $4 \%+1.1$. & 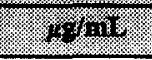 & $(6)=111=$ \\
\hline $19-5771$ & 53: 2 & Homog. test & $<10.1$ & $<10.1$ & $<10.1^{\text {ec:d }}$ \\
\hline $22-5771$ & $54: 2$ & Homog. test & 1.26 & 1.26 & 1.26 \\
\hline
\end{tabular}


Table B2-41. Tank 241-T-105 Analytical Results: Nitrate (IC).

\begin{tabular}{|c|c|c|c|c|c|}
\hline \multirow{2}{*}{\multicolumn{2}{|c|}{ 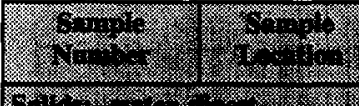 }} & 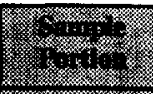 & 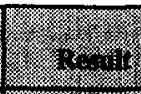 & $\frac{1}{1}+1$. & (2), \\
\hline & & (M) & 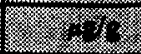 & 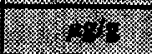 & - $7.1 \%$ \\
\hline $25-7771$ & 53: 1 & Homog. test & 26,400 & 27,400 & 26,900 \\
\hline 33-7771 & 54:1 & Homog. test & 15,500 & 15,500 & 15,500 \\
\hline \multicolumn{3}{|c|}{ 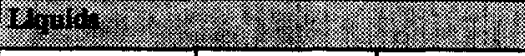 } & 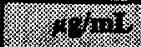 & 1.9 .1 & .7 .841 \\
\hline $19-5771$ & 53: 2 & Homog. test & 8,060 & 8,180 & 8,120 \\
\hline $22-5771$ & 54: 2 & Homog. test & 5.47 & 5.65 & 5.56 \\
\hline
\end{tabular}

Table B2-42. Tank 241-T-105 Analytical Results: Nitrite (IC).

\begin{tabular}{|c|c|c|c|c|c|}
\hline 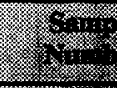 & 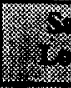 & (3) & 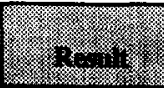 & 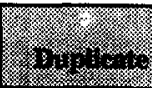 & 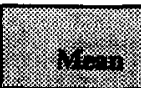 \\
\hline (c) & 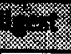 & 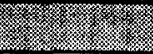 & 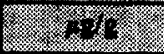 & 2.14 & 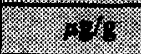 \\
\hline $25-7771$ & 53: 1 & Homog. test & 37,000 & 38,700 & 37,850 \\
\hline 33-7771 & 54: 1 & Homog. test & 21,500 & 22,100 & 21,800 \\
\hline $\mathrm{H}_{13}+\mathrm{i}$ & 3. & & 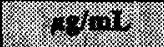 & $(5)+111$ & (1) \\
\hline $19-5771$ & 53: 2 & Homog, test & 11,700 & 11,600 & 11,650 \\
\hline $22-5771$ & $54: 2$ & Homog. test & 50.3 & 47.8 & 49.05 \\
\hline
\end{tabular}

Table B2-43. Tank 241-T-105 Analytical Results: Phosphate (IC).

\begin{tabular}{|c|c|c|c|c|c|}
\hline 40 & $8 \%$ & 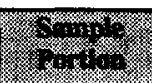 & 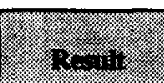 & 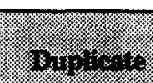 & $1 \%$ \\
\hline \multicolumn{2}{|c|}{ Soliter } & (2) & 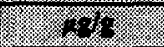 & (2) - $17 \%$ & $1 \% 1 \%$ \\
\hline $25-7771$ & $53: 1$ & Homog. test & 2,670 & 2,550 & 2,610 \\
\hline 33-7771 & 54: 1 & Homog. test & 1,760 & 1,770 & 1,765 \\
\hline Shuters & 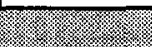 & י) & , & 8. & . \\
\hline $19-5771$ & $53: 2$ & Homog. test & 1,600 & 1,560 & 1,580 \\
\hline $22-5771$ & $54: 2$ & Homog. test & $<1$ & $<1$ & $<1$ \\
\hline
\end{tabular}


Table B2-44. Tank 241-T-105 Analytical Results: Sulfate (IC).

\begin{tabular}{|c|c|c|c|c|c|}
\hline 40 & (2) & $=2$ & (2) & $a_{1}(1)=1$ & . \\
\hline S., I V V & $\mathrm{n}^{2}$ & (7) & $=1$ & $1 \%$ & 28 \\
\hline $25-7771$ & 53: 1 & Homog. test & 10,700 & 11,000 & 10,850 \\
\hline 33-7771 & 54: 1 & Homog. test & 6,210 & 6,290 & 6,250 \\
\hline Mon & 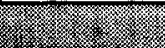 & & 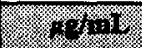 & 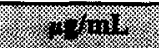 & (8) \\
\hline $19-5771$ & $53: 2$ & Homog. test & 3,480 & 3,500 & 3,490 \\
\hline $22-5771$ & $54: 2$ & Homog. test & 41.6 & 41.9 & 41.75 \\
\hline
\end{tabular}

Table B2-45. Tank 241-T-105 Analytical Results: Hydroxide (Titration).

\begin{tabular}{|c|c|c|c|c|c|}
\hline 40 & 80 & 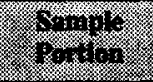 & $=0$. & Buplis.tis & 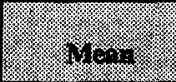 \\
\hline $601.1 \%=$ & & & 7. & (2) & 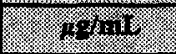 \\
\hline $25-5724$ & 53:1 & Homog. test & $<1,250 \mu \mathrm{g} / \mathrm{g}$ & $<1,250 \mu \mathrm{g} / \mathrm{g}$ & $<1,250 \mu \mathrm{g} / \mathrm{g}$ \\
\hline $33-5724$ & 54: 1 & Homog. test & $<125$ & $<125$ & $<125$ \\
\hline$V_{6}, 146$ & & & (- $4.61 \%$ & 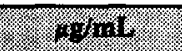 & $.1 .6 \mathrm{mil}$ \\
\hline $19-5729$ & 53: 2 & Homog. test & 376 & 357 & 366.5 \\
\hline
\end{tabular}

Table B2-46. Tank 241-T-105 Analytical Results: Cyanide (Distillation/Spectrometry).

\begin{tabular}{|c|c|c|c|c|c|}
\hline 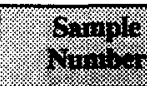 & 6 & 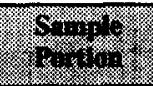 & (2) & 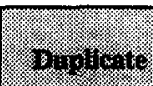 & 11. \\
\hline Soris & 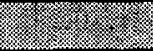 & 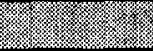 & $9 \%$ & $\%$ & $(1 \%$ \\
\hline $25-5777$ & 53: 1 & Homog. test & 7.85 & 25.1 & $16.475^{\mathrm{QC}: \mathrm{E}}$ \\
\hline $33-5777$ & 54: 1 & Homog. test & 5.84 & 6.67 & 6.255 \\
\hline
\end{tabular}


Table B2-47. Tank 241-T-105 Analytical Results: Nitrite (Spectrophotometric).

\begin{tabular}{|c|c|c|c|c|c|}
\hline 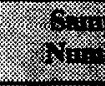 & 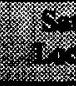 & 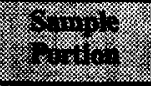 & 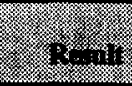 & 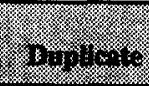 & s. \\
\hline \multicolumn{3}{|c|}{ 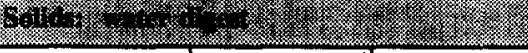 } & (s) & th & $x$ \\
\hline $25-7779$ & 53: 1 & Homog. test & 277 & 275 & $276^{\mathrm{QC}: \mathrm{c}}$ \\
\hline $33-7779$ & 54: 1 & Homog. test & 738 & 688 & 713 \\
\hline (1) & & & $4 \%$ & (x) & \% \\
\hline $19-5779$ & $53: 2$ & Homog. test & 17,400 & 17,600 & 17,500 \\
\hline
\end{tabular}

Table B2-48. Tank 241-T-105 Analytical Results: Total organic carbon (Furnace Oxidation).

\begin{tabular}{|l|l|l|l|l|l|}
\hline & & & & \\
\hline
\end{tabular}

Table B2-49. Tank 241-T-105 Analytical Results: Total organic carbon (Persulfate Oxidation).

\begin{tabular}{|c|c|c|c|c|c|}
\hline 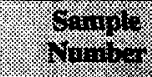 & 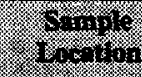 & $\frac{0.1+10}{400}$ & 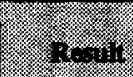 & $\left(\operatorname{los}_{10}\right)$ & 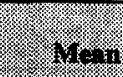 \\
\hline $6001 \%$ & (2) & & $(1 \%$ & $4 \%$ & $2,1 \%$ \\
\hline 93-07986-J1 & $54: 1$ & Homog. test & 2,790 & 2,440 & 2,615 \\
\hline 93-07987-J1 & 57: 1 & Homog. test & 5,380 & 5,180 & 5,280 \\
\hline 93-07988-J1 & $57: 2$ & Homog. test & 1,630 & 1,630 & 1,630 \\
\hline
\end{tabular}


Table B2-50. Tank 241-T-105 Analytical Results: Total Inorganic Carbon. (Persulfate Oxidation)

\begin{tabular}{|l|l|l|l|l|}
\hline 7 & & & & \\
\end{tabular}

Table B2-51. Tank 241-T-105 Analytical Results: Total Inorganic Carbon (TIC).

\begin{tabular}{|l|l|l|l|l|l|}
\hline & & & \\
\hline
\end{tabular}

Table B2-52. Tank 241-T-105 Analytical Results: Pu238 to Pu ratio (Mass Spec.).

\begin{tabular}{|c|c|c|c|c|c|}
\hline (6) & 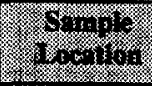 & 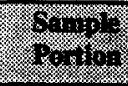 & 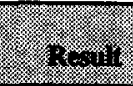 & $8+1)$ & tritit \\
\hline $6 \%$ & & & 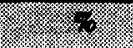 & 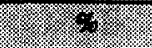 & $\%$ \\
\hline 93-7985-H-1 & $54: 1$ & Whole & 0.193 & 0.19 & 0.1915 \\
\hline
\end{tabular}


Table B2-53. Tank 241-T-105 Analytical Results: Pu239 to Pu ratio (Mass Spec.).

\begin{tabular}{|c|c|c|c|c|c|}
\hline 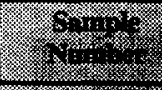 & (3) & 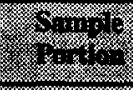 & 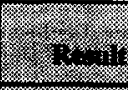 & 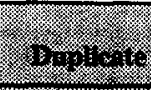 & 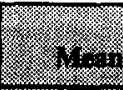 \\
\hline 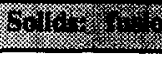 & 格 & (3) & 8 & 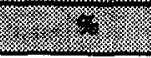 & 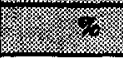 \\
\hline 93-7985-H-1 & 54: 1 & Whole & 96.469 & 96.239 & 96.354 \\
\hline
\end{tabular}

Table B2-54. Tank 241-T-105 Analytical Results: Pu240 to Pu ratio (Mass Spec.).

\begin{tabular}{|c|c|c|c|c|c|}
\hline (1) & 8 & $\frac{4}{4+19}$ & (3) & 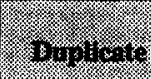 & 杘: \\
\hline 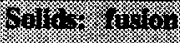 & & & r. & 3 & 8 \\
\hline 93-7985-H-1 & $54: 1$ & Whole & 3.188 & 3.328 & 3.258 \\
\hline
\end{tabular}

Table B2-55. Tank 241-T-105 Analytical Results: Pu241 to Pu ratio (Mass Spec.).

\begin{tabular}{|c|c|c|c|c|c|}
\hline 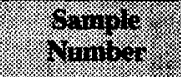 & 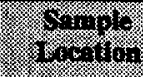 & 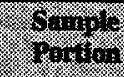 & 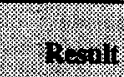 & 6) & $4,8=2 n$ \\
\hline 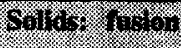 & & & $\%$ & 4 & 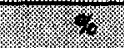 \\
\hline 93-7985-H-1 & $54: 1$ & Whole & 0.11 & 0.16 & $0.135^{\alpha C: e}$ \\
\hline
\end{tabular}

Table B2-56. Tank 241-T-105 Analytical Results: Pu242 to Pu ratio (Mass Spec.).

\begin{tabular}{|c|c|c|c|c|c|}
\hline 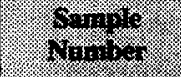 & $\frac{1}{4}$ & 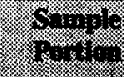 & 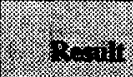 & 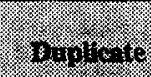 & 4 \\
\hline 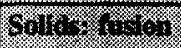 & & & x. & . & 8 \\
\hline 93-7985-H-1 & $54: 1$ & Whole & 0.04 & 0.08 & $0.06^{\alpha \mathrm{C}: e}$ \\
\hline
\end{tabular}

Table B2-57. Tank 241-T-105 Analytical Results: U234 to U ratio (Mass Spec.).

\begin{tabular}{|c|c|c|c|c|c|}
\hline 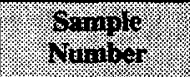 & 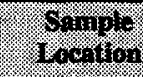 & $\frac{x}{40}$ & 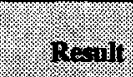 & 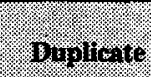 & ing \\
\hline 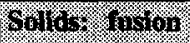 & & אצ & \% & \% & \% \\
\hline 93-7985-H-1 & $54: 1$ & Whole & 0.006 & 0.006 & 0.006 \\
\hline
\end{tabular}


Table B2-58. Tank 241-T-105 Analytical Results: U235 to U ratio (Mass Spec.).

\begin{tabular}{|c|c|c|c|c|c|}
\hline 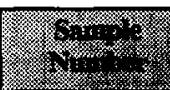 & (6) & 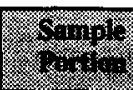 & (2) & 20 & 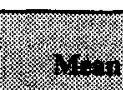 \\
\hline ( & $\gamma_{\gamma}$ & 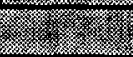 & ( & 18 & . \\
\hline 93-7985-H-1 & $54: 1$ & Whole & 0.688 & 0.688 & 0.688 \\
\hline
\end{tabular}

Table B2-59. Tank 241-T-105 Analytical Results: U236 to U ratio (Mass Spec.).

\begin{tabular}{|c|c|c|c|c|c|}
\hline (1) & $\frac{1}{4}$ & 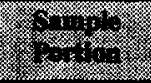 & 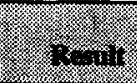 & 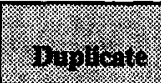 & 1) \\
\hline (a) 1 & 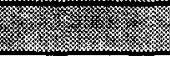 & 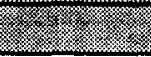 & 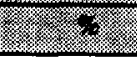 & (- & . \\
\hline 93-7985-H-1 & 54: 1 & Whole & 0.006 & 0.006 & 0.006 \\
\hline
\end{tabular}

Table B2-60. Tank 241-T-105 Analytical Results: U238 to U ratio (Mass Spec.).

\begin{tabular}{|c|c|c|c|c|c|}
\hline 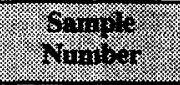 & $4 \sin 20$ & $\frac{3}{2010}$ & insail & 143ingto & 40 \\
\hline Wiolow & 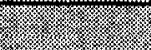 & & 8 & Y. & $\%$ \\
\hline 93-7985-H-1 & 54: 1 & Whole & 99.3 & 99.3 & 99.3 \\
\hline
\end{tabular}

Table B2-61. Tank 241-T-105 Analytical Results: Total Alpha (Alpha Rad).

\begin{tabular}{|c|c|c|c|c|c|}
\hline Monger & 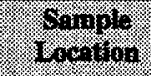 & 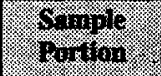 & ingentin & Puplicate & Higan \\
\hline \multicolumn{2}{|c|}{ 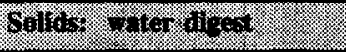 } & & $4 \%$ & $10 \%$ & $4 \%$ \\
\hline $25-7725$ & 53: 1 & Homog, test & 0.00559 & 0.00519 & 0.00539 \\
\hline $33-7725$ & 54: 1 & Homog. test & 0.00338 & 0.00345 & 0.003415 \\
\hline Frons & & & 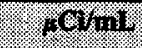 & $\% 1+11$ & $6 \%$ \\
\hline $19-5725$ & 53: 2 & Whole & 0.0266 & 0.0285 & $0.02755^{\mathrm{QC}: \mathrm{d}}$ \\
\hline Sollast 69013 & & & $.4 \%$ & 19 & matg \\
\hline $25-6725$ & 53: 1 & Homog. test & 0.815 & 0.823 & 0.819 \\
\hline $33-6725$ & $54: 1$ & Homog. test & 0.485 & 0.464 & 0.4745 \\
\hline
\end{tabular}


Table B2-62. Tank 241-T-105 Analytical Results: Total alpha Pu (Alpha Rad).

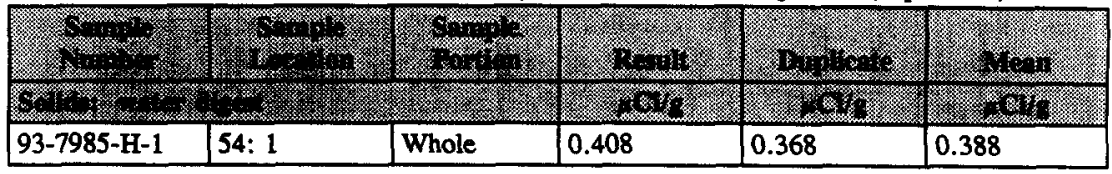

Table B2-63. Tank 241-T-105 Analytical Results: Americium-241 (Alpha Spec).

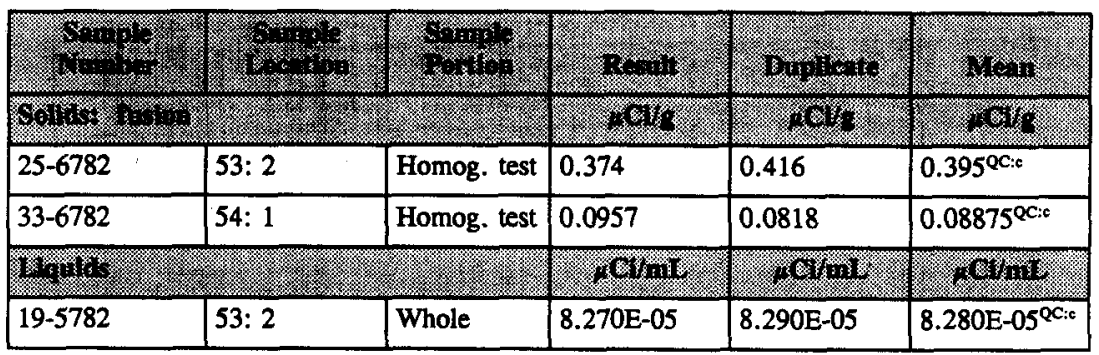

Table B2-64. Tank 241-T-105 Analytical Results: Plutonium-238 (Alpha Spec).

\begin{tabular}{|c|c|c|c|c|c|}
\hline $4 \%$ & 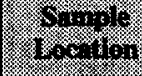 & $\frac{2519}{4}$ & $36-11$ & $840,4+1=$ & 19 \\
\hline Sx, & (2) & & (x) & 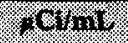 & $10 \% 11$ \\
\hline $19-5782$ & 53: 2 & Whole & $<2.450 \mathrm{E}-04$ & -- & $<2.450 \mathrm{E}-04^{\mathrm{OC}: c}$ \\
\hline
\end{tabular}

Table B2-65. Tank 241-T-105 Analytical Results: Plutonium-239/40 (Alpha Spec)..

\begin{tabular}{|c|c|c|c|c|c|}
\hline 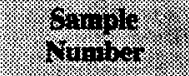 & (4) & 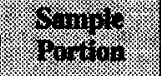 & 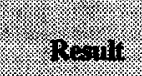 & Hipicire & (19.2. \\
\hline 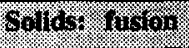 & & & 16\% & 16 & 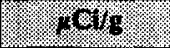 \\
\hline $25-6781$ & $53: 2$ & Homog. test & 0.137 & 0.135 & 0.136 \\
\hline $33-6781$ & $54: 1$ & Homog. test & 0.153 & 0.128 & 0.1405 \\
\hline $1 \%$ & & & 161,11 & 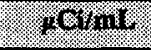 & 7. \\
\hline $19-5782$ & $53: 2$ & Whole & $1.880 \mathrm{E}-04$ & $\cdots$ & $1.880 \mathrm{E}-04^{\mathrm{QC}: \mathrm{c}}$ \\
\hline
\end{tabular}


Table B2-66. Tank 241-T-105 Analytical Results: Total Beta (Beta Proportional Counting).

\begin{tabular}{|c|c|c|c|c|c|}
\hline (3) & $(2,8)$ & 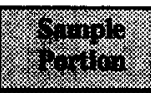 & (3) & 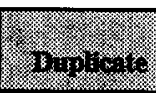 & (2) \\
\hline 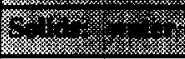 & 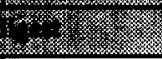 & ( & . & 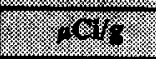 & \% \\
\hline $25-7720$ & 53: 1 & Homog. test & 46.9 & 50.2 & 48.55 \\
\hline $33-7720$ & 54: 1 & Homog. test & 27.1 & 26.6 & 26.85 \\
\hline $4+1=$ & 8 & 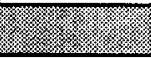 & ram & 4 & $16 \%$ \\
\hline $19-5720$ & $53: 2$ & Whole & 24 & 23.3 & 23.65 \\
\hline 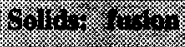 & 3 & & 28 & 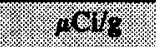 & $4 \%$ \\
\hline $25-6720$ & 53: 1 & Homog. test & 1,260 & 1,250 & $1,255^{\mathrm{QC}: \mathrm{b}}$ \\
\hline $33-6720$ & 54: 1 & Homog. test & 510 & 432 & 471 \\
\hline
\end{tabular}

Table B2-67. Tank 241-T-105 Analytical Results: Strontium-90

(Beta Proportional Counting).

\begin{tabular}{|c|c|c|c|c|c|}
\hline$\frac{60010}{60}$ & 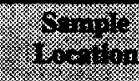 & 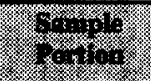 & $9+2.11$ & $(k+1)$ & 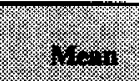 \\
\hline $6011 \%$ & 8 & $\sqrt[3]{-8.8}$ & (2) & 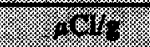 & (2) \\
\hline $25-6782$ & $53: 2$ & Homog. test & 407 & 395 & 401 \\
\hline $33-6786$ & 54: 1 & Homog. test & 173 & 146 & 159.5 \\
\hline Uinivis: & 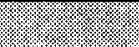 & (2):-2: & $18 \%$ & 461.910 & $.196 \mathrm{kmi}$ \\
\hline $19-5786$ & 53: 2 & Whole & 0.382 & 0.365 & $0.3735^{\mathrm{oC}: \mathrm{a}}$ \\
\hline
\end{tabular}


HNF-SD-WM-ER-369 Rev. 1

Table B2-68. Tank 241-T-105 Analytical Results: Americium-241 (GEA).

\begin{tabular}{|c|c|c|c|c|c|}
\hline 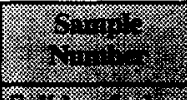 & (2) & 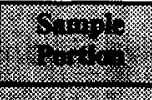 & 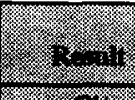 & 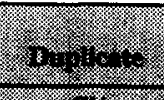 & (2) \\
\hline $201,1,2$ & 8 (1) & স্য & 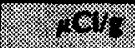 & . & 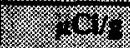 \\
\hline $25-6730$ & 53: 1 & Homog. test & $<0.767$ & $<0.77$ & $<0.7685$ \\
\hline $33-6730$ & 54: 1 & Homog. test & $<0.134$ & $<0.125$ & $<0.1295$ \\
\hline 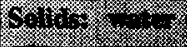 & 2 & (3) - - - - & 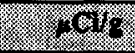 & 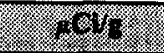 & 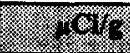 \\
\hline $25-7730$ & 53: 1 & Homog. test & $<0.163$ & $<0.164$ & $<0.1635$ \\
\hline $28-9730$ & & $\begin{array}{l}\text { Residual } \\
\text { solids }\end{array}$ & 1.3 & 1.64 & $1.47^{\mathrm{QC:e}}$ \\
\hline $33-7730$ & 54: 1 & Homog. test & $<0.129$ & $<0.13$ & $<0.1295$ \\
\hline $37-9730$ & & $\begin{array}{l}\text { Residual } \\
\text { solids }\end{array}$ & 0.296 & 0.193 & $0.2445^{\mathrm{QC}: e}$ \\
\hline
\end{tabular}

Table B2-69. Tank 241-T-105 Analytical Results: Antimony-125 (GEA).

\begin{tabular}{|c|c|c|c|c|c|}
\hline$=8$ & $y^{2}$ & 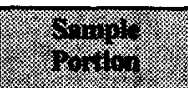 & 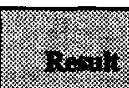 & 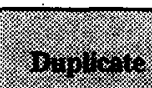 & $4=$ \\
\hline 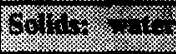 & 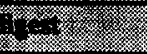 & 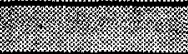 & 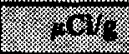 & 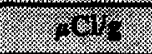 & 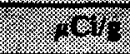 \\
\hline $28-9730$ & 53: 1 & Residual solids & 0.59 & 0.74 & $0.665^{\mathrm{QC}: \mathrm{s}}$ \\
\hline
\end{tabular}


Table B2-70. Tank 241-T-105 Analytical Results: Ce/Pr-144 (GEA).

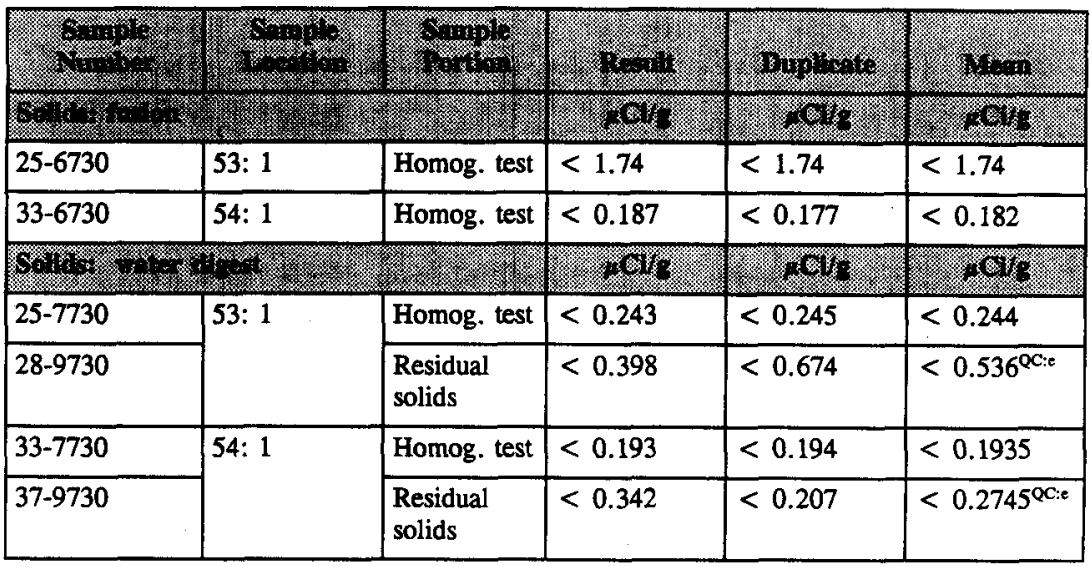

Table B2-71. Tank 241-T-105 Analytical Results: Cesium-134 (GEA).

\begin{tabular}{|c|c|c|c|c|c|}
\hline (3) & 40 & $4 \%$ & (1) & 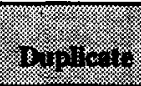 & 40 \\
\hline 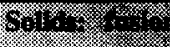 & 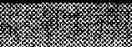 & ) & 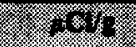 & (1) & 4. \\
\hline $25-6730$ & 53: 1 & Homog. test & $<0.106$ & $<0.0992$ & $<0.1026$ \\
\hline $33-6730$ & $54: 1$ & Homog. test & $<0.00757$ & $<0.00721$ & $<0.00739$ \\
\hline \multicolumn{2}{|c|}{ foli, r. } & & 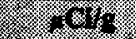 & (2) & 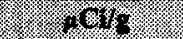 \\
\hline $25-7730$ & \multirow[t]{2}{*}{$53: 1$} & Homog. test & $<0.0115$ & $<0.0126$ & $<0.01205$ \\
\hline $28-9730$ & & $\begin{array}{l}\text { Residual } \\
\text { solids }\end{array}$ & $<0.0173$ & $<0.032$ & $<0.02465^{\text {Qc: }: e}$ \\
\hline $33-7730$ & \multirow[t]{2}{*}{$54: 1$} & Homog. test & $<0.0112$ & $<0.012$ & $<0.0116$ \\
\hline $37-9730$ & & $\begin{array}{l}\text { Residual } \\
\text { solids }\end{array}$ & $<0.0116$ & $<0.00761$ & $<0.009605^{\mathrm{QC:e}}$ \\
\hline
\end{tabular}


Table B2-72. Tank 241-T-105 Analytical Results: Cesium-137 (GEA).

\begin{tabular}{|c|c|c|c|c|c|}
\hline$\left(\frac{1}{4}\right)$ & $\frac{1}{2}$ & 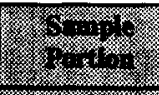 & 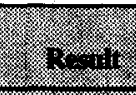 & roplat & $2,1+$ \\
\hline 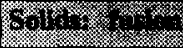 & (2) & - & 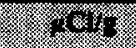 & (2) & 18 \\
\hline $25-6730$ & 53: 1 & Homog. test & 61 & 62.7 & 61.85 \\
\hline $33-6730$ & 54: 1 & Homog. test & 38.1 & 35.2 & 36.65 \\
\hline 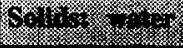 & 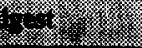 & 2 & 8.2 .115$. & - & - \\
\hline $25-7730$ & 53: 1 & Homog. test & 40.7 & 40.8 & 40.75 \\
\hline $28-9730$ & & $\begin{array}{l}\text { Residual } \\
\text { solids }\end{array}$ & 53.3 & 77.92 & $65.61^{\mathrm{QC}: \mathrm{e}}$ \\
\hline $33-7730$ & 54: 1 & Homog. test & 23.9 & 23.8 & 23.85 \\
\hline $37-9730$ & & $\begin{array}{l}\text { Residual } \\
\text { solids }\end{array}$ & 57.5 & 33.5 & $45.5^{\mathrm{OC:}: \mathrm{e}}$ \\
\hline
\end{tabular}

Table B2-73. Tank 241-T-105 Analytical Results: Cobalt-60 (GEA).

\begin{tabular}{|c|c|c|c|c|c|}
\hline 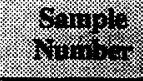 & 㳔 & $\frac{1}{3}+\frac{1}{3}$ & 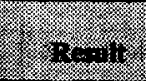 & 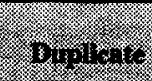 & 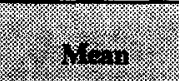 \\
\hline \multicolumn{3}{|c|}{$6 \mathrm{~g}, 14 \%$} & (3) & 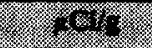 & $1 \%$ \\
\hline $25-6730$ & $53: 1$ & Homog, test & $<0.0909$ & $<0.0913$ & $<0.0911$ \\
\hline $33-6730$ & $54: 1$ & Homog. test & $<0.00688$ & 0.0195 & $<0.01319^{\mathrm{QC} e}$ \\
\hline \multicolumn{3}{|c|}{ 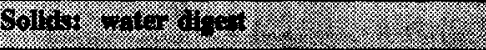 } & (1) & $46 \%$ & 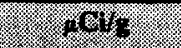 \\
\hline $25-7730$ & \multirow[t]{2}{*}{ 53: 1} & Homog. test & $<0.0136$ & $<0.0131$ & $<0.01335$ \\
\hline $28-9730$ & & $\begin{array}{l}\text { Residual } \\
\text { solids }\end{array}$ & 0.043 & 0.0634 & $0.0532^{Q \mathrm{C}: \mathrm{e}}$ \\
\hline $33-7730$ & \multirow[t]{2}{*}{ 54: 1} & Homog. test & $<0.0117$ & $<0.0119$ & $<0.0118$ \\
\hline $37-9730$ & & $\begin{array}{l}\text { Residual } \\
\text { solids }\end{array}$ & 0.0254 & 0.0213 & 0.02335 \\
\hline
\end{tabular}


Table B2-74. Tank 241-T-105 Analytical Results: Europium-154 (GEA).

\begin{tabular}{|c|c|c|c|c|c|}
\hline 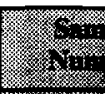 & 2 & 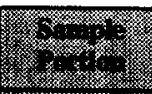 & 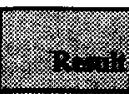 & 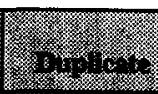 & 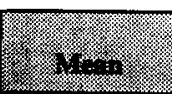 \\
\hline 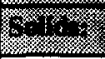 & $\sqrt{3}$ & rit. & . & 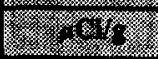 & 63 \\
\hline $25-6730$ & 53: 1 & Homog. test & 1.24 & $<0.295$ & $<0.7675^{\circ C: e}$ \\
\hline $33-6730$ & 54: 1 & Homog. test & 0.247 & 0.218 & 0.2325 \\
\hline 6014. & 10 & - & 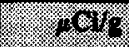 & (2. & 40 \\
\hline $25-7730$ & 53: 1 & Homog. test & $<0.0372$ & $<0.0371$ & $<0.03715$ \\
\hline $28-9730$ & & $\begin{array}{l}\text { Residual } \\
\text { solids }\end{array}$ & 2.7 & 3.3 & 3 \\
\hline $33-7730$ & 54: 1 & Homog. test & $<0.0418$ & $<0.0344$ & $<0.0381$ \\
\hline $37-9730$ & & $\begin{array}{l}\text { Residual } \\
\text { solids }\end{array}$ & 0.71 & 0.438 & $0.574^{\mathrm{QC}: \mathrm{e}}$ \\
\hline
\end{tabular}

Table B2-75. Tank 241-T-105 Analytical Results: Europium-155 (GEA).

\begin{tabular}{|c|c|c|c|c|c|}
\hline 40 & 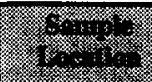 & 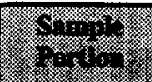 & 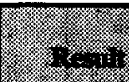 & $\frac{1}{8}+4 \cdot 4$ & 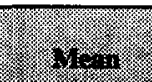 \\
\hline 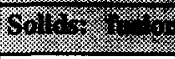 & (3) & l. & . 16 & 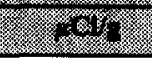 & .9619 \\
\hline $25-6730$ & 53: 1 & Homog. test & 1.19 & $<0.486$ & $<0.838^{\mathrm{QC:c}}$ \\
\hline $33-6730$ & 54: 1 & Homog. test & 0.216 & 0.196 & 0.206 \\
\hline \multicolumn{2}{|c|}{ 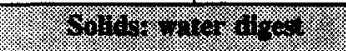 } & (1) & 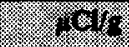 & 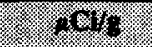 & 1948 \\
\hline $25-7730$ & \multirow[t]{2}{*}{ 53: 1} & Homog. test & $<0.0748$ & $<0.0743$ & $<0.07455$ \\
\hline $28-9730$ & & $\begin{array}{l}\text { Residual } \\
\text { solids }\end{array}$ & 3.2 & 4 & $3.6^{\mathrm{Qc}: \mathrm{e}}$ \\
\hline $33-7730$ & \multirow[t]{2}{*}{ 54: 1} & Homog, test & $<0.0583$ & $<0.0592$ & $<0.05875$ \\
\hline $37-9730$ & & $\begin{array}{l}\text { Residual } \\
\text { solids }\end{array}$ & 0.761 & 0.484 & $0.6225^{\mathrm{QC:e}}$ \\
\hline
\end{tabular}


Table B2-76. Tank 241-T-105 Analytical Results: Potassium-40 (GEA).

\begin{tabular}{|c|c|c|c|c|c|}
\hline 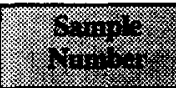 & 2 & ( & 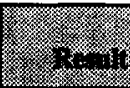 & 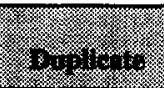 & 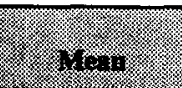 \\
\hline 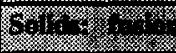 & 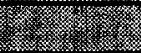 & (1) & 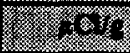 & 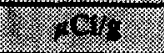 & 2.20 \\
\hline $25-6730$ & 53: 1 & Homog. test & $<2.95$ & $<2.92$ & $<2.935$ \\
\hline $33-6730$ & $54: 1$ & Homog. test & $<0.152$ & $<0.151$ & $<0.1515$ \\
\hline \multicolumn{3}{|c|}{ 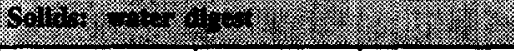 } & 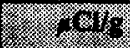 & 10.961 & 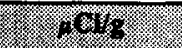 \\
\hline $25-7730$ & \multirow[t]{2}{*}{ 53: 1} & Homog. test & 0.324 & $<0.322$ & $<0.323$ \\
\hline $28-9730$ & & $\begin{array}{l}\text { Residual } \\
\text { solids }\end{array}$ & $<0.0562$ & $<0.099$ & $<0.0776^{\mathrm{QC:e}}$ \\
\hline $33-7730$ & \multirow[t]{2}{*}{ 54: 1} & Homog. test & 0.396 & 0.316 & $0.356^{\mathrm{ec}: \mathrm{e}}$ \\
\hline $37-9730$ & & $\begin{array}{l}\text { Residual } \\
\text { solids }\end{array}$ & $<0.0606$ & $<0.0353$ & $<0.04795^{\circ \mathrm{C}:}$ \\
\hline
\end{tabular}

Table B2-77. Tank 241-T-105 Analytical Results: Ruthenium-103 (GEA).

\begin{tabular}{|c|c|c|c|c|c|}
\hline 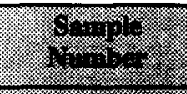 & (3) & 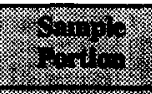 & 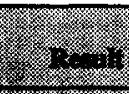 & 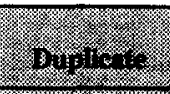 & 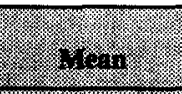 \\
\hline Sely & (3) & - - - - & 201 & 2.09 & 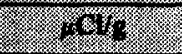 \\
\hline $25-6730$ & 53: 1 & Homog. test & $<0.164$ & $<0.164$ & $<0.164$ \\
\hline $33-6730$ & 54: 1 & Homog. test & $<0.0236$ & $<0.023$ & $<0.0233$ \\
\hline $601 \%=3,-1,=$ & 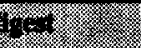 & 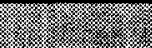 & (2) 19 & $8 \%$ & .964 \\
\hline $25-7730$ & \multirow[t]{2}{*}{ 53: 1} & Homog. test & $<0.0354$ & $<0.0353$ & $<0.03535$ \\
\hline $28-9730$ & & $\begin{array}{l}\text { Residual } \\
\text { solids }\end{array}$ & $<0.0244$ & $<0.0438$ & $<0.0341^{\text {QC:e }}$ \\
\hline $33-7730$ & \multirow[t]{2}{*}{$54: 1$} & Homog. test & $<0.0274$ & $<0.0275$ & $<0.02745$ \\
\hline $37-9730$ & & $\begin{array}{l}\text { Residual } \\
\text { solids }\end{array}$ & $<0.0245$ & $<0.015$ & $<0.01975^{\mathrm{QC}: \mathrm{e}}$ \\
\hline
\end{tabular}


Table B2-78. Tank 241-T-105 Analytical Results: Ruthenium/Rhodium-106 (GEA).

\begin{tabular}{|c|c|c|c|c|c|}
\hline 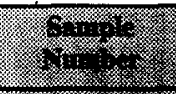 & $\frac{1}{6}+6$ & (1) & 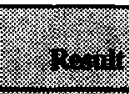 & 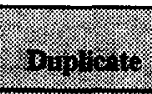 & $-2.1 \%$ \\
\hline $\mathrm{COF}$ & (3) & (2) & (1) & 3. & 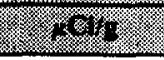 \\
\hline $25-6730$ & 53: 1 & Homog. test & $<1.93$ & $<2.14$ & $<2.035$ \\
\hline $33-6730$ & 54: 1 & Homog. test & $<0.31$ & $<0.296$ & $<0.303$ \\
\hline 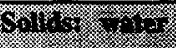 & +2 & (3) & 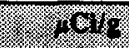 & (5) & 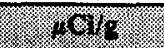 \\
\hline $25-7730$ & \multirow[t]{2}{*}{ 53: 1} & Homog. test & $<0.451$ & $<0.482$ & $<0.4665$ \\
\hline $28-9730$ & & $\begin{array}{l}\text { Residual } \\
\text { solids }\end{array}$ & $<0.34$ & $<0.621$ & $<0.4805^{Q C: e}$ \\
\hline $33-7730$ & \multirow[t]{2}{*}{ 54: 1} & Homog. test & $<0.391$ & $<0.385$ & $<0.388$ \\
\hline $37-9730$ & & $\begin{array}{l}\text { Residual } \\
\text { solids }\end{array}$ & $<0.31$ & $<0.19$ & $<0.25^{\mathrm{QC:c}}$ \\
\hline
\end{tabular}

Table B2-79. Tank 241-T-105 Analytical Results: Thorium-228 (GEA).

\begin{tabular}{|c|c|c|c|c|c|}
\hline (2) & 8 & 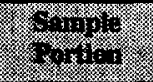 & (y.ria) & $8+1919$ & 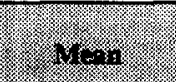 \\
\hline $\mathrm{CeN}=2$ & 2:-1:-8: & 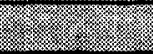 & 2.94 & $2.6 \%$ & rofy \\
\hline $25-6730$ & 53: 1 & Homog. test & $<0.261$ & $<0.268$ & $<0.2645$ \\
\hline $33-6730$ & 54: 1 & Homog. test & $<0.0355$ & $<0.0336$ & $<0.03455$ \\
\hline \multicolumn{2}{|c|}{ 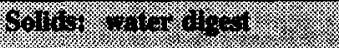 } & (3) & 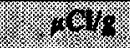 & 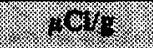 & 1,918 \\
\hline $25-7730$ & \multirow[t]{2}{*}{ 53: 1} & Homog. test & $<0.0517$ & $<0.0514$ & $<0.05155$ \\
\hline $28-9730$ & & $\begin{array}{l}\text { Residual } \\
\text { solids }\end{array}$ & $<0.048$ & $<0.0828$ & $<0.0654^{\mathrm{QC:c}}$ \\
\hline $33-7730$ & \multirow[t]{2}{*}{ 54: 1} & Homog. test & $<0.0409$ & $<0.0414$ & $<0.04115$ \\
\hline $37-9730$ & & $\begin{array}{l}\text { Residual } \\
\text { solids }\end{array}$ & $<0.0456$ & $<0.0279$ & $<0.03675^{Q \mathrm{C}: \mathrm{e}}$ \\
\hline
\end{tabular}


Table B2-80. Tank 241-T-105 Analytical Results: Carbon-14 (Liq. Scin.).

\begin{tabular}{|c|c|c|c|c|c|}
\hline 4 & 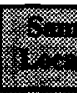 & $\frac{1}{2}+1.1 \%$ & 2 & $8+912$ & l. \\
\hline s. & 1. & (2) & 3. & (3) & (3) \\
\hline 28-7788 & 53: 1 & Homog. test & $9.270 \mathrm{E}-04$ & 0.00173 & $0.0013285^{\mathrm{QC:a,c}}$ \\
\hline $37-7788$ & 54: 1 & Homog. test & 5.850E-04 & $7.840 \mathrm{E}-04$ & $6.845 \mathrm{E}-04^{\mathrm{QC}: e}$ \\
\hline
\end{tabular}

Table B2-81. Tank 241-T-105 Analytical Results: Tritium (Liq. Scin.).

\begin{tabular}{|l|l|l|l|l|}
\hline & & & & \\
\hline
\end{tabular}

Table B2-82. Tank 241-T-105 Analytical Results: Technetium-99 (Liq. Scin.).

\begin{tabular}{|c|c|c|c|c|c|}
\hline 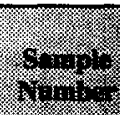 & 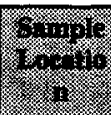 & (2) & 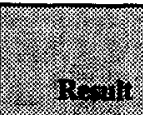 & 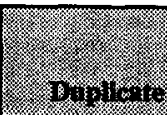 & 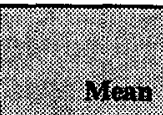 \\
\hline \multicolumn{2}{|c|}{$6013 \%$ \% } & & . & 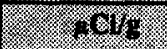 & $1 \%$ \\
\hline $25-6782$ & 53: 2 & Homog. test & $<0.17$ & $<0.167$ & $<0.1685^{Q \mathrm{QC}: \mathrm{c}}$ \\
\hline $33-6784$ & $54: 1$ & Homog. test & 0.399 & 0.345 & $0.372^{\mathrm{QC} ; \mathrm{c}}$ \\
\hline Woys & & & 306013 & 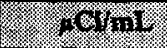 & (2) \\
\hline $19-5784$ & $53: 2$ & Homog. test & 0.0649 & 0.0605 & $0.0627^{\mathrm{QC}: \mathrm{c}}$ \\
\hline
\end{tabular}


Table B2-83. Tank 241-T-105 Analytical Results: Weight Percent Solids (Percent Solids).

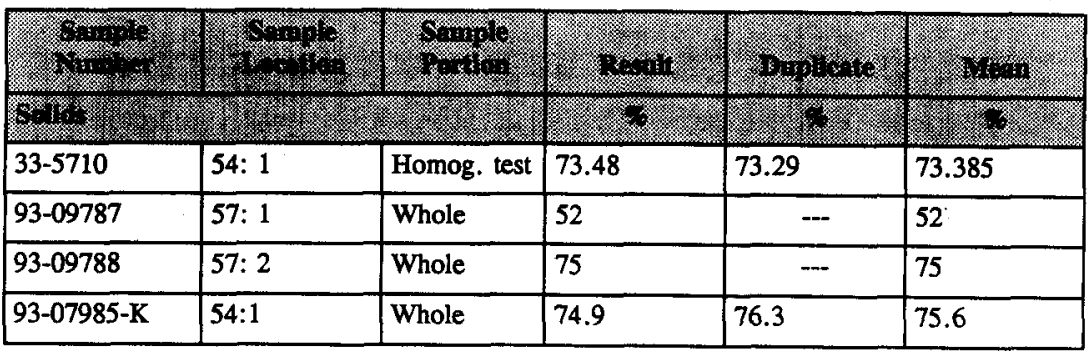

Table B2-84. Tank 241-T-105 Analytical Results: Weight Percent Centrifuged Solids. (Physical Properties)

\begin{tabular}{|c|c|c|c|c|c|}
\hline - & 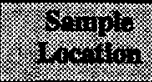 & $2 \%$ & 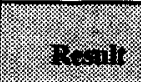 & 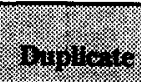 & 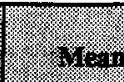 \\
\hline Solls: : & 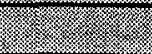 & 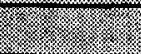 & 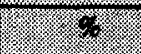 & 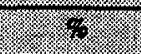 & 12 \\
\hline 93-09787 & 57:1 & Whole & 98 & - & 98 \\
\hline
\end{tabular}

Table B2-85. Tank 241-T-105 Analytical Results: Weight Percent Residual Solids (Percent Solids).

\begin{tabular}{|c|c|c|c|c|c|}
\hline 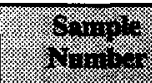 & 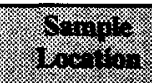 & 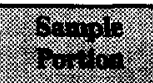 & 3. & 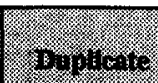 & $19=$ \\
\hline \multicolumn{2}{|c|}{ 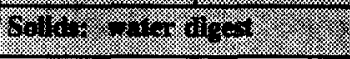 } & (1) & 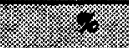 & (- & $\%$ \\
\hline $37-9710$ & 54: 1 & Homog. test & 37.95 & 67.48 & $52.715^{\mathrm{QC}: \mathrm{e}}$ \\
\hline
\end{tabular}


Table B2-86a. Tank 241-T-105 Analytical Results: Density (Physical Properties).

\begin{tabular}{|c|c|c|c|c|c|}
\hline$\left(\frac{1}{2}\right)$ & (1) & $\left(\frac{1}{2}\right)$ & 3. & 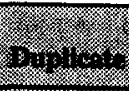 & (2) \\
\hline 861\% & 8 & 20 & 19u & 7.not? & $=\sqrt{1.13}$ \\
\hline Not given & 53: 1 & Whole & $0.89^{1}$ & -- & 0.89 \\
\hline Not given & 54: 1 & Whole & $2.01^{1}$ & - & 2.01 \\
\hline $93-09787$ & \multirow[t]{4}{*}{ 57: 1} & Whole & $1.1^{1}$ & $\cdots$ & 1.1 \\
\hline $93-09787$ & & Whole (1:3 dilution) & $1.03^{2}$ & --- & 1.03 \\
\hline $93-09787$ & & Whole (1:1 dilution) & $1.12^{2}$ & --- & 1.12 \\
\hline $93-09787$ & & Whole & $1.54^{2}$ & --- & 1.54 \\
\hline $93-09788$ & \multirow[t]{2}{*}{ 57: 2} & Whole & $1.07^{1}$ & --- & 1.07 \\
\hline 93-09788 & & Whole & $1.74^{2}$ & $\cdots$ & 1.74 \\
\hline
\end{tabular}

Notes:

'Density was estimated by dividing sample mass by the sample volume

${ }^{2}$ Analytically measured density

Table B2-86b. Tank 241-T-105 Analytical Results: Density (Physical Properties).

\begin{tabular}{|c|c|c|c|c|c|}
\hline $\begin{array}{l}\text { Somis } \\
\text { Sint? }\end{array}$ & 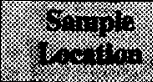 & 90 & 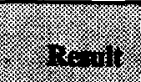 & 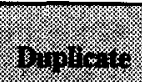 & 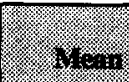 \\
\hline SY & (3) & 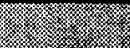 & 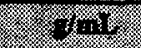 & 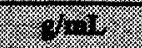 & \%w \\
\hline Not given & 53: 2 & Whole & $0.88^{1}$ & -- & 0.88 \\
\hline Not given & 54:1 & Whole & $1.48^{1}$ & $\cdots$ & 1.48 \\
\hline Not given & $54: 2$ & Whole & $0.97^{1}$ &.- & 0.97 \\
\hline
\end{tabular}

Note:

'Density was estimated by dividing sample mass by the sample volume 
Table B2-87. Tank 241-T-105 Analytical Results: Centrifuged Supernate Density (Physical Properties).

\begin{tabular}{|c|c|c|c|c|c|}
\hline 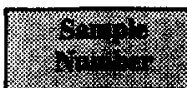 & 1) & 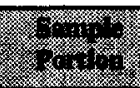 & 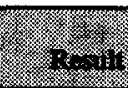 & 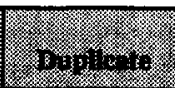 & (2) \\
\hline (1) & . & $\sqrt[3]{3.7 .3}$ & 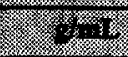 & 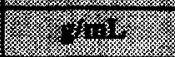 & 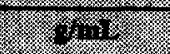 \\
\hline 93-09787 & 57: 1 & Whole & 1.0 & -- & 1.0 \\
\hline
\end{tabular}

Table B2-88. Tank 241-T-105 Analytical Results: Centrifuged Solids Density (Physical Properties).

\begin{tabular}{|c|c|c|c|c|c|}
\hline 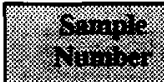 & 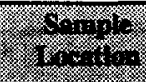 & 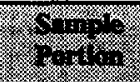 & 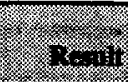 & inpilingtite & in:m \\
\hline Solos & 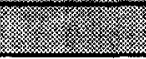 & . & 94 & 4:1: & $\%$ \\
\hline 93-09787 & $57: 1$ & Whole & 1.56 & --- & 1.56 \\
\hline
\end{tabular}

Table B2-89. Tank 241-T-105 Analytical Results: Specific Gravity (SpG).

\begin{tabular}{|c|c|c|c|c|c|}
\hline 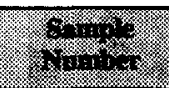 & (2) & 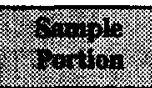 & 8 & 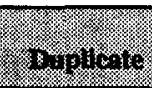 & 4. \\
\hline Gigunts = & (1) & (-) & intwing & ingly $=5$ & $9191=$ \\
\hline $19-5706$ & 53: 2 & Whole & 1.05 & 1.05 & 1.05 \\
\hline $22-5706$ & $54: 2$ & Whole & 0.986 & 0.984 & 0.985 \\
\hline
\end{tabular}


Table B2-90. Tank 241-T-105 Analytical Results: Volume Percent Settled Solids (Physical Properties).

\begin{tabular}{|c|c|c|c|c|c|}
\hline 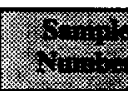 & . & 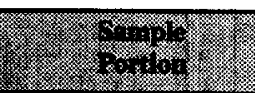 & . & 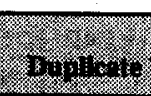 & $\sqrt{3}+i_{i}$ \\
\hline \multicolumn{3}{|c|}{ 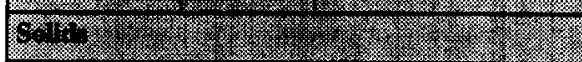 } & $\sqrt{2.83}$ & $\sqrt{2}$ & $\sqrt{28.8}$ \\
\hline 93-09787 & \multirow[t]{3}{*}{ 57: 1} & Whole (1:3 dilution) & 39 & -- & 39 \\
\hline $93-09787$ & & Whole (1:1 dilution) & 70 & -- & 70 \\
\hline 93-09787 & & Whole & 100 & --- & 100 \\
\hline $93-09788$ & \multirow[t]{3}{*}{ 57: 2} & Whole (1:3 dilution) & 17 & -- & 17 \\
\hline $93-09788$ & & Whole (1:1 dilution) & 31 & -- & 31 \\
\hline $93-09788$ & & Whole & 100 & $\ldots$ & 100 \\
\hline
\end{tabular}

Table B2-91. Tank 241-T-105 Analytical Results: Volume Percent Centrifuged Solids (Physical Properties).

\begin{tabular}{|c|c|c|c|c|c|}
\hline ( & ( & Sarigle & 2 & Eapicen & 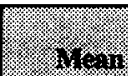 \\
\hline Solv & (2) & 2-3:- & 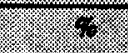 & ( & $\sqrt{6}$ \\
\hline $93-09787$ & 57: 1 & Whole & 96 & --- & 96 \\
\hline $93-09788$ & 57: 2 & Whole & 98 & $-\ldots$ & 98 \\
\hline
\end{tabular}

Table B2-92. Tank 241-T-105 Analytical Results: Total Dissolved Solids (Percent Solids).

\begin{tabular}{|c|c|c|c|c|c|}
\hline 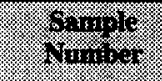 & 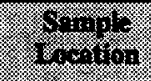 & 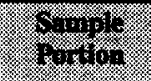 & escill & B. 1310 & itim \\
\hline \multicolumn{2}{|c|}{ 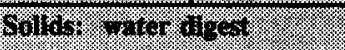 } & & (2):-8. & $17 \%$ & : \\
\hline $25-7705$ & 53: 1 & Homog. test & 0.24 & 0.32 & $0.28^{\circ \mathrm{CO}: \mathrm{e}}$ \\
\hline $33-7705$ & 54: 1 & Homog. test & 0.09 & 0.12 & $0.105^{\mathrm{QC}: \mathrm{e}}$ \\
\hline
\end{tabular}


HNF-SD-WM-ER-369 Rev. 1

Table B2-93. Tank 241-T-105 Analytical Results: Consistency Factor (Physical Properties).

\begin{tabular}{|c|c|c|c|c|c|}
\hline (1) & (2) & 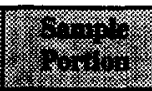 & 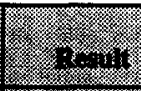 & 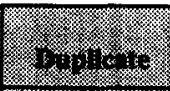 & (it) \\
\hline $4 \%$ & (1) & 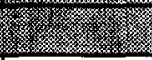 & V. & 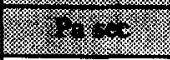 & 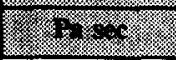 \\
\hline $93-07987$ & 57: 1 & $\begin{array}{l}\text { Whole (1:1 } \\
\text { dilution) }\end{array}$ & 0.036 & 0.028 & $0.032^{\text {QCie }}$ \\
\hline
\end{tabular}

Table B2-94. Tank 241-T-105 Analytical Results: Flow Behavior Index (Physical Properties).

\begin{tabular}{|c|c|c|c|c|c|}
\hline 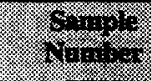 & (2) & $\frac{1}{6}$ & yon & ing: & 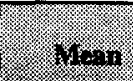 \\
\hline $6 \%$ & . & & 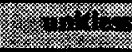 & 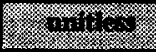 & (4) \\
\hline 93-07987 & $57: 1$ & $\begin{array}{l}\text { Whole (1:1 } \\
\text { dilution) }\end{array}$ & .074 & 0.86 & 0.8 \\
\hline
\end{tabular}

Table B2-95. Tank 241-T-105 Analytical Results: Yield Point (Physical Properties).

\begin{tabular}{|c|c|c|c|c|c|}
\hline 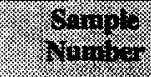 & (1) & 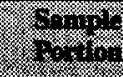 & 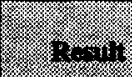 & 8101 & 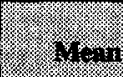 \\
\hline $80 \%$ & ; & (2. & \% & 48 & 4 \\
\hline 93-07987 & 57: 1 & Whole & 6.8 & 6.0 & 6.4 \\
\hline
\end{tabular}


Table B2-96. Tank 241-T-105 Analytical Results: Exothermic Results (DSC).

\begin{tabular}{|c|c|c|c|c|c|c|}
\hline anding & (3) & (3) & $\frac{1}{2}$ & 2 & 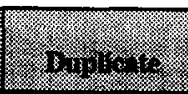 & 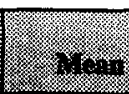 \\
\hline $3 \%$ & (1) & (1) & 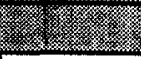 & (1) & (2) 18 & (2) \\
\hline 93-07987 & 57: 1 & Whole & 2 & 167 & 180 & 174 \\
\hline $9^{1}$ & 53: 1 & Whole & 2 & 13 & -- & 13 \\
\hline $9^{1}$ & 53: 1 & Whole & 3 & 17.3 & $\ldots$ & 17.3 \\
\hline
\end{tabular}

Note:

'This was the only sample number listed on the DSC scans.

Table B2-97. Tank 241-T-105 Analytical Results: Percent Water (TGA)..

\begin{tabular}{|c|c|c|c|c|c|}
\hline 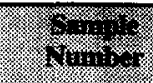 & 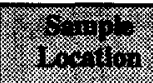 & (2) & 2.2 .111 & $(3+3) 19$ & 13 \\
\hline 20116 & 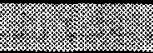 & . & 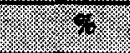 & 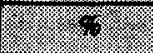 & 6. \\
\hline $9-5712$ & $53: 1$ & Whole & 51.97 & - & 51.97 \\
\hline 93-07987 & 57: 1 & Whole & 48.7 & 46.5 & 47.6 \\
\hline 93-07988 & 57: 2 & Whole & 19.8 & 19.1 & 20 \\
\hline 140 & (- & (3) & . & 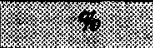 & \% \\
\hline $19-5712$ & 53: 2 & Whole & 91.42 & 91.36 & 91.39 \\
\hline $8-5712$ & 54: 2 & Whole & 35.52 & --- & 35.52 \\
\hline
\end{tabular}


Table B2-98. Analysis of Sample T-4937 from Tank 241-T-105 (Collected in 1974).'

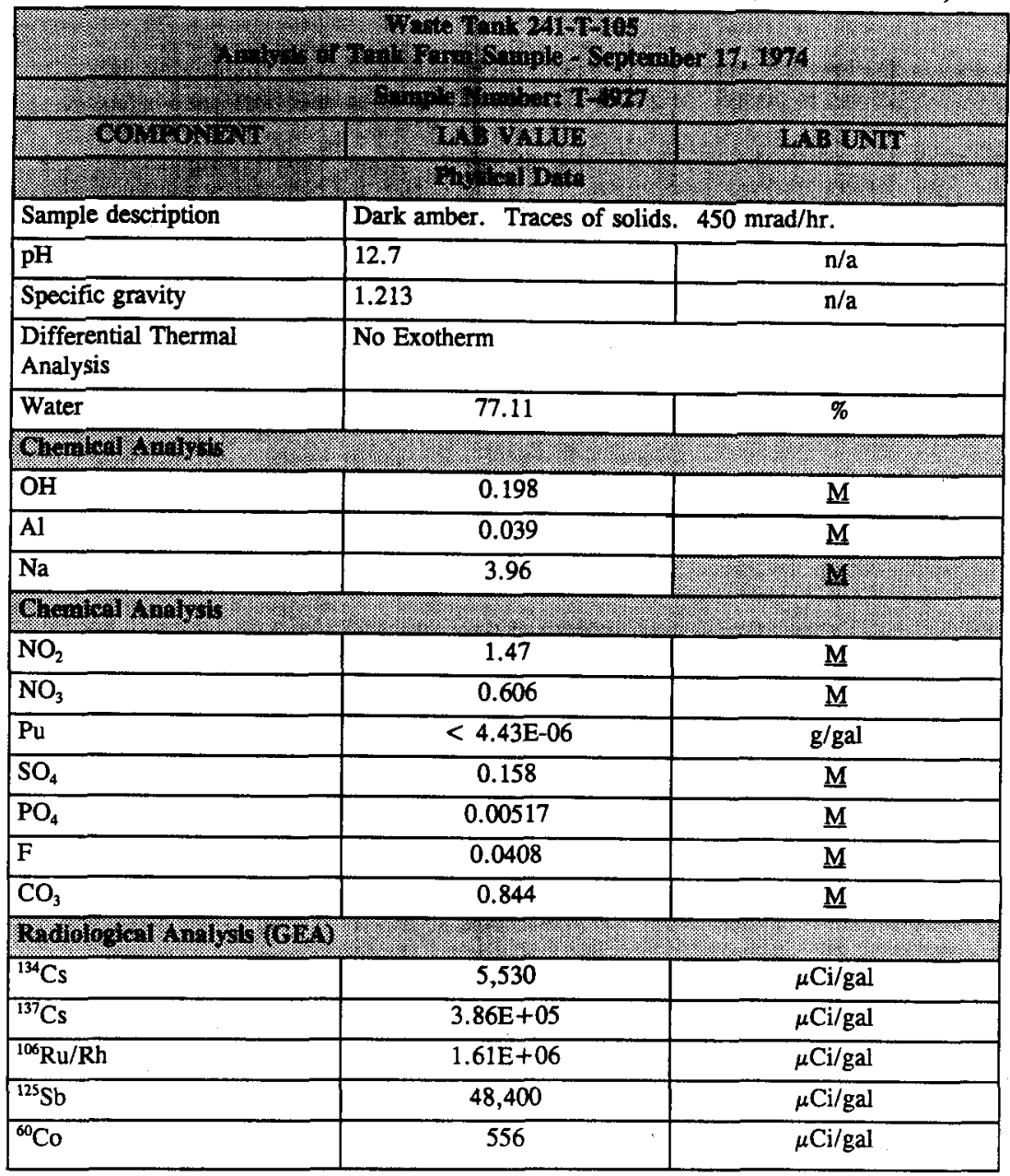

Note:

'Wheeler 1974 


\section{B3.0 ASSESSMENT OF CHARACTERIZATION RESULTS}

The section discusses the overall quality and consistency of the current sampling results for tank 241-T-105 and to present the results of the calculation of an analytical-based inventory.

This section also evaluates sampling and analysis factors that may impact interpretation of the data. These factors are used to assess the overall data quality and consistency and to identify limitations in data use.

\section{B3.1 GENERAL OBSERVATIONS}

Recoveries of the segments taken from tank 241-T-105 were poor. Core 53 had recoveries of 18 percent and approximately 59 percent for segments 1 and 2, respectively. Core 54 had the best recoveries, with 36 percent for segment 1 and 91 percent for segment 2 . However, segment 2 of core 54 was entirely liquid; this liquid is believed to be the water used as a hydrostatic head fluid during sampling instead of actual tank waste. Core 57 had the worst recovery, with 8 percent for both segments. It is likely that full vertical waste profiles were not obtained because of the low recoveries. Consequently, the waste analyzed may not represent all waste in the tank.

From the hot cell chemists' visual observations of the waste, it was apparent that the waste was heterogeneous, varying horizontally and vertically. In the horizontal plane, the first segments of each core vary in consistency, ranging from a muddy texture to a brittle and crumbly texture. The color also differs between the first segments in core 53 and 54 . The second segments of each core also contrast: one is almost entirely composed of solids, and the other two are primarily liquids. The density of the waste from cores 53 and 57 vary

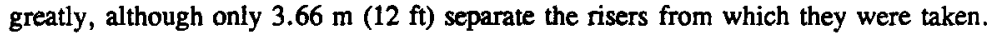

From the same observations, it is evident that the waste varies vertically. Only core 57 remains constant between segments with respect to liquid and solid percents. Both cores 53 and 54 are predominately solid in segment 1 and liquid in segment 2. Further evidence of vertical waste variance is present in segment 1 of core 54; the color ranges between dark brown and white within $48 \mathrm{~cm}$ (19 in.). This color change and consistency variation led to the determination by the hot cell chemist that segment 1 of core 54 was heterogeneous. It is doubtful that the cascade inlet from the previous tank had much influence on the heterogeneity exhibited by this tank because the nearest riser sampled was over $7.62 \mathrm{~m}$ $(25 \mathrm{ft})$ from the inlet. 


\section{B3.2 QUALITY CONTROL ASSESSMENT}

The usual QC assessment includes an evaluation of the appropriate standard recoveries, spike recoveries, duplicate analyses, and blanks that are performed in conjunction with chemical analyses. All the pertinent QC tests were conducted on the 1993 samples. Bell (1993) established the specific criteria for all analytes. Sample and duplicate pairs that had one or more QC results outside the specified criteria were identified by superscripts in the data summary tables.

The standard and spike recovery results provide an estimate of the accuracy of the analysis. If a standard or spike recovery is above or below the given criterion, the analytical results may be biased high or low, respectively. The precision is estimated by the relative percent difference (RPD), which is defined as the absolute value of the difference between the primary and duplicate samples, divided by their mean, times one hundred.

Standard recoveries fell outside the limits for several analytes, although no deviation was large. A number of ICP analytes had spike recoveries outside the limits. The high dilutions required to adequately detect analytes can cause poor or meaningless spike recoveries for those ICP elements that had very high concentrations (for example, sodium) or were close to the detection limit (for example, selenium). One spike recovery was outside the target level for total alpha activity. Total alpha results were difficult to obtain because of high salt resulting from KOH fusion (Giamberardini 1993). The high spike recovery for fluoride was caused by masking by an unknown peak next to fluoride during the analysis. Many analytes had RPDs outside the limits, but these were usually close to the limits and attributed to sample heterogeneity. High dilutions can also affect RPDs in the same manner as the spikes as discussed above. Finally, no sample exceeded the criterion for preparation blanks listed in Bell (1993) ( $\leq 20$ percent of the sample value). Therefore, contamination was not a problem.

In summary, the vast majority of the QC results were within the boundaries specified. Discrepancies mentioned here and footnoted in the data summary tables were generally small and should not impact data validity or use.

\section{B3.3 DATA CONSISTENCY CHECKS}

Comparisons of different analytical methods can help to assess data consistency and quality. Several correlations were possible with the data set provided by the two core samples, including comparisons of phosphorous and sulfur as analyzed by ICP with phosphate and sulfate as analyzed by IC, and a comparison of total alpha activity and total beta activity with the sum of their individual emitters. In addition, mass and charge balances were calculated to help assess overall data consistency. 


\section{B3.3.1 Comparison of Results from Different Analytical Methods}

The following data consistency checks compare results from two analytical methods. Close agreement between the two methods strengthens the credibility of both results, but a poor agreement brings the reliability of the data into question.

Phosphorus is determined by ICP, and phosphate is determined by IC. Assuming that all the phosphorus is present as phosphate yielded mean concentrations of $4,570 \mu \mathrm{g} / \mathrm{g}$ for the aciddigested sample and 4,690 $\mu \mathrm{g} / \mathrm{g}$ for the fusion-digested sample. Both values are over twice the IC value for phosphate $(2,190 \mu \mathrm{g} / \mathrm{g})$. This indicates that approximately half of the phosphate is water-soluble. A better comparison would be between the phosphate results and the water digested phosphorus data. The water digested phosphorus mean was $655 \mu \mathrm{g} / \mathrm{g}$, which converted to a phosphate value of $2,010 \mu \mathrm{g} / \mathrm{g}$. This value agreed with the IC phosphate mean.

Sulfur is considered to be present as the sulfate ion and appears to be completely watersoluble. The sulfate concentrations calculated from the ICP water digest, ICP fusion, and ICP acid digest values for sulfur are $8,280,7,860$, and $7,830 \mu \mathrm{g} / \mathrm{g}$, respectively. These values agree with the IC water digest sulfate concentration of $8,550 \mu \mathrm{g} / \mathrm{g}$.

A comparison was made between the individual alpha emitters and the total alpha activity to determine the level of data consistency. This comparison was possible only on the drainable liquids and the fusion digested solids. Results are shown in Table B3-1.

Table B3-1. Total Alpha Activity Comparison.

\begin{tabular}{|c|c|c|}
\hline l. & 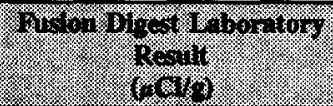 & 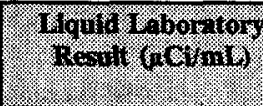 \\
\hline${ }^{241} \mathrm{Am}$ & 0.242 & $8.28 \mathrm{E}-05$ \\
\hline $239 / 240 \mathrm{Pu}$ & 0.138 & $1.88 \mathrm{E}-04$ \\
\hline Sum & 0.38 & $1.35 \mathrm{E}-04$ \\
\hline Total alpha activity (mean) & 0.647 & 0.02755 \\
\hline
\end{tabular}

A comparison was also made between the gross beta result and the sum of the individual beta emitters. This comparison was only possible for the fusion digested solids. The activity of the individual beta emitters is summed by using the following equation:

$$
2\left[{ }^{90} \mathrm{Sr}(1.42)\right]+{ }^{137} \mathrm{Cs}(1.51)
$$


The coefficients, 1.42 and 1.51 , are the corrections for calibration of the detector with ${ }^{60} \mathrm{Co}$. The total beta results are based on the efficiency of the detector for ${ }^{60} \mathrm{Co}$. Because the ${ }^{60} \mathrm{Co}$ is lower in energy than the isotopes, the total beta results are usually biased high. To correct for this, the efficiency factor is taken into account. Table B3-2 indicates, agreement between the beta activity sum and the gross beta results.

Table B3-2. Total Beta Activity Comparison.

\begin{tabular}{|l|c|}
\hline & Per \\
\hline${ }^{0} \mathrm{Sr}$ & 280 \\
\hline${ }^{137} \mathrm{Cs}$ & 49.3 \\
\hline Beta sum ${ }^{1}$ & 870 \\
\hline Gross beta result & 863 \\
\hline
\end{tabular}

Note:

${ }^{\text {beta sum }}=2\left({ }^{\infty 0} \mathrm{Sr}[1.42]\right)+{ }^{137} \mathrm{Cs}(1.51)$

\section{B3.3.2 Mass and Charge Balances}

The principle objective in performing mass and charge balances is to determine whether the measurements are consistent. Mass and charge balances were calculated separately for segment 1 of cores 53 and 54 in Herting (1993). A discussion of the results from the Herting balances have been reproduced here.

For core 53, mass and charge balances were performed separately for the fusion and acid digest data. The core 53 acid digest analysis yielded a low mass balance of 92.6 percent, which may be caused by incomplete dissolution of the samples. The fact that the acid digest charge baiance is excellent (0.99) suggests a factor that influences the sample as a whole, such as incomplete dissolution rather than an incorrect analytical result for one or more sample components. The charge balance for the core 53 fusion analysis $(0.89)$ was lower than it was for the acid digest analysis. This reflects the lower sodium result for the fusion sample. One would expect these numbers to be the same, because sodium compounds should be completely dissolved in both treatments. Because the two sodium values (acid digest/fusion) differ by about 10 percent and the same value for anions is used for both samples, the difference in charge balance is also about 10 percent. The higher overall mass balance for the fusion analysis ( 95.0 percent) reflects the higher aluminum result in the fusion. 
For core 54, mass and charge balances were performed separately for water, fusion, and acid digest results. The very low mass balance for the water digest sample ( 38.5 percent) is caused by incomplete dissolution and is to be expected. The charge balance, which does not depend on complete sample dissolution, is excellent (0.96). The acid digest results yielded a mass balance of 86.1 percent and a charge balance of 1.10 . The fusion results gave a mass balance of 88.7 percent and a charge balance of 0.99 . No further discussion or explanation was provided for these balances.

Overall tank mass and charge balances were also performed. Because the results used in these balances were taken from Table B3-6, they are based solely on segment 1 of cores 53 and 54. Only analytes detected at a concentration of $1,000 \mu \mathrm{g} / \mathrm{g}$ or greater were considered. The means based on the fusion digested samples were used in the balances because, in most cases, the fusion digestion yielded a more conservative (higher) mean estimate.

Except for sodium, all analytes were assumed to be present in their most common hydroxide, oxide, or phosphate forms. For example, aluminum hydroxide $\left(\mathrm{Al}(\mathrm{OH})_{3}\right)$ was the assumed species for aluminum because there were large endothermic reactions at $300^{\circ} \mathrm{C}$. Although smaller concentrations of other forms of aluminum such as aluminosilicate are probably present in the waste also, they were not included in order to keep the mass-charge balance calculations simple and consistent. Because precipitates are neutral species, all positive charge was attributed to the sodium cations.

Phosphorus was determined by ICP, and phosphate was determined by IC. Assuming that all phosphorus was present as phosphate and converting the mean phosphorus concentration accordingly yields a concentration of $4,690 \mu \mathrm{g} / \mathrm{g}$ for the fusion-digested results. This was approximately twice the IC phosphate value of $2,190 \mu \mathrm{g} / \mathrm{g}$. It was assumed that the extra phosphate exists as insoluble precipitates of bismuth and iron as shown in Table B3-3. Sulfur was considered to be present as the sulfate ion and appears to be completely watersoluble (see Section B3.3.1). The concentrations for the two carbon-containing anions, acetate and carbonate, were derived from the TOC and TIC analyses, respectively. The anions were assumed to be present as sodium salts and were expected to balance the positive charge exhibited by the cations.

The concentrations of the cations listed in Table B3-3, the anions listed in Table B3-4, and the weight percent water results were ultimately used to calculate the mass balance. The mass balance can be calculated from the formula below. The factor 0.0001 is the conversion factor from $\mu \mathrm{g} / \mathrm{g}$ to weight percent.

$\begin{aligned} \text { Mass balance }= & \% \text { Water }+0.0001 \times\{\text { Total Analyte Concentration }\} \\ = & \% \text { Water }+0.0001 \times\left\{\left[\mathrm{Al}(\mathrm{OH})_{3}\right]+\left[\mathrm{BiPO}_{4}\right]+[\mathrm{CaO}]+\left[\mathrm{FePO}_{4}\right]+\right. \\ & {[\mathrm{FeO}(\mathrm{OH})]+[\mathrm{MgO}]+\left[\mathrm{MnO}_{2}\right]+\left[\mathrm{Na}^{+}\right]+\left[\mathrm{SiO}_{2}\right]+\left[\mathrm{NO}_{3}{ }^{-}\right]+} \\ & {\left.\left[\mathrm{NO}_{2}^{-}\right]+\left[\mathrm{PO}_{4}{ }^{3-}\right]+\left[\mathrm{SO}_{4}{ }^{2-}\right]+\left[\mathrm{CO}_{3}{ }^{2-}\right]+\left[\mathrm{C}_{2} \mathrm{H}_{3} \mathrm{O}_{2}{ }^{-}\right]\right\} }\end{aligned}$


The total analyte concentrations calculated from the above equation was $519,000 \mu \mathrm{g} / \mathrm{g}$. The mean weight percent water for segment 1 of core 53 was 51.97 percent, as determined by TGA. Only gravimetry was performed on segment 1 of core 54, yielding a weight percent water mean of 26.6 percent. The mean of these two values is 39.3 percent; this is the weight percent water value used in the mass balance. The mass balance resulting from adding the weight percent water to the total analyte concentration was 91.2 percent, as shown in Table B3-5.

The charge balance is the ratio of total cations $(\mu \mathrm{eq} / \mathrm{g})$ to total anions ( $\mu \mathrm{eq} / \mathrm{g})$.

Total cations $(\mu \mathrm{eq} / \mathrm{g})=\left[\mathrm{Na}^{+}\right] / 23.0=2,140 \mu \mathrm{eq} / \mathrm{g}$

Total anions $(\mu \mathrm{eq} / \mathrm{g})=\left[\mathrm{NO}_{3}{ }^{-}\right] / 62.0+\left[\mathrm{NO}_{2}^{-}\right] / 46.0+\left[\mathrm{PO}_{4}{ }^{3}\right] / 31.7+\left[\mathrm{SO}_{4}{ }^{2}\right] / 48.0+$ $\left[\mathrm{CO}_{3}{ }^{2-}\right] / 30.0+\left[\mathrm{C}_{2} \mathrm{H}_{3} \mathrm{O}_{2}^{-}\right] / 59.0$

The charge balance obtained by dividing the sum of the positive charges by the sum of the negative charges was 0.90 .

In summary, the above calculations yield reasonable mass and charge balance values (close to 1.00 for charge balance and 100 percent for mass balance), indicating that the analytical results are generally consistent. Although these mass and charge balances were obtained from mean concentrations from several samples, they agree reasonably well with the mass and charge balance analysis carried out in Herting (1993).

Table B3-3. Cation Mass and Charge Data.

\begin{tabular}{|c|c|c|c|c|}
\hline (2.1.1. & 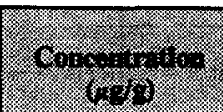 & 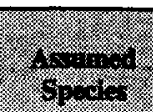 & 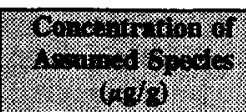 & $\left(\frac{6}{6} .1 \%\right)$ \\
\hline Aluminum & 95,100 & $\mathrm{Al}(\mathrm{OH})_{3}$ & 275,000 & 0 \\
\hline Bismuth & 1,220 & $\mathrm{BiPO}_{4}$ & 1,770 & 0 \\
\hline$\overline{\text { Calcium }}$ & 3,670 & $\mathrm{CaO}$ & 5,140 & 0 \\
\hline \multirow[t]{2}{*}{ Iron } & 1,150 & $\mathrm{FePO}_{4}$ & 3,110 & 0 \\
\hline & 32,000 & $\mathrm{FeO}(\mathrm{OH})$ & 50,900 & 0 \\
\hline Magnesium & 1,100 & $\mathrm{MgO}$ & 1,800 & 0 \\
\hline Manganese & 10,400 & $\mathrm{MnO}_{2}$ & 16,500 & 0 \\
\hline Sodium & 49,200 & $\mathrm{Na}^{+}$ & 49,200 & 2,140 \\
\hline Silicon & 6,980 & $\mathrm{SiO}_{2}$ & 14,900 & 0 \\
\hline \multicolumn{3}{|l|}{ Total } & 418,000 & 2,140 \\
\hline
\end{tabular}


Table B3-4. Anion Mass and Charge Data.

\begin{tabular}{|c|c|c|c|c|}
\hline 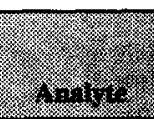 & (2) & (2) & 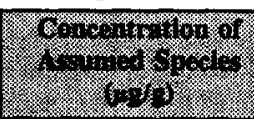 & 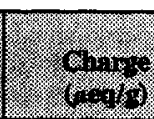 \\
\hline Nitrate & 21,200 & $\mathrm{NO}_{3}^{-}$ & 21,200 & 342 \\
\hline Nitrite & 29,800 & $\mathrm{NO}_{2}^{-}$ & 29,800 & 648 \\
\hline Phosphate & 2,190 & $\mathrm{PO}_{4}^{3}$ & 2,190 & 69 \\
\hline Sulfate & 8,550 & $\mathrm{SO}_{4}^{2-}$ & 8,550 & 178 \\
\hline TIC & 5,670 & $\mathrm{CO}_{3}{ }^{2-}$ & 28,400 & 947 \\
\hline TOC & 4,590 & $\mathrm{C}_{2} \mathrm{H}_{3} \mathrm{O}_{2}^{-}$ & 11,300 & 192 \\
\hline \multicolumn{3}{|l|}{ Total } & 101,000 & 2,380 \\
\hline
\end{tabular}

Table B3-5. Mass Balance Totals.

\begin{tabular}{|l|l|}
\hline & \\
\hline Total from Table B3-3 & 418,000 \\
\hline Total from Table B3-4 & 101,000 \\
\hline Weight percent water & 393,000 \\
\hline Grand total & 912,000 \\
\hline
\end{tabular}

\section{B3.4 CALCULATION OF ANALYTICAL BASED MEANS}

The statistics in this section were calculated using analytical data from the most recent sampling event of tank 241-T-105. Analysis of variance techniques were used to estimate the mean and to calculate confidence limits on the mean for each analyte that had all results above the detection limit.

Liquid and solid sample material was insufficient to perform all required chemical analyses. Sample material also was insufficient to make core composite samples. Consequently, the statistical results presented here pertain to the solid material in segment 1 from cores 53 and 54. This means that the summary statistics in this report do not reflect the composition of the entire tank. 
A chemical analysis was performed on the drainable liquid portion of the sample from segment 1 , cores 53 and 54 . However, the drainable liquid portion of core 54 , segment 1 , was clear and appeared to be the water used as the hydrostatic fluid (Silvers and Sasaki 1993). Consequently, no summary statistics for the drainable liquid data are reported.

For analytes, with all values above the detection limit, an estimate of the mean concentration and confidence interval on the mean concentration were calculated. These estimates are shown in Table B3-6.

Table B3-6. Concentration Estimate Statistics (Units in $\mu \mathrm{g} / \mathrm{g}$ Except Radionuclides $[\mu \mathrm{Ci} / \mathrm{g}]$ ). (3 sheets)

\begin{tabular}{|l|l|l|l|l|l|}
\hline & & & & & \\
\hline ICP.a.Ag & 16.6 & 10.1 & 1 & 0.00 & 57.1 \\
\hline ICP.a.Al & 92,400 & $3.73 \mathrm{E}+09$ & 1 & 0.00 & $8.68 \mathrm{E}+05$ \\
\hline ICP.a.Bi & 1,330 & 5,260 & 1 & 406 & 2,250 \\
\hline ICP.a.Ca & 1,420 & 6,810 & 1 & 369 & 2,470 \\
\hline ICP.a.Cr & 505 & 49,000 & 1 & 0.00 & 3,320 \\
\hline ICP.a.Fe & 27,300 & $3.32 \mathrm{E}+08$ & 1 & 0.00 & $2.59 \mathrm{E}+05$ \\
\hline ICP.a.K & 305 & 8,560 & 1 & 0.00 & 1,480 \\
\hline ICP.a.Mg & 1,060 & 2,010 & 1 & 494 & 1,630 \\
\hline ICP.a.Mn & 11,600 & $6.83 \mathrm{E}+07$ & 1 & 0.00 & $1.17 \mathrm{E}+05$ \\
\hline ICP.a.Mo & 34 & 41 & 1 & 0.00 & 116 \\
\hline ICP.a.Na & 56,300 & $1.51 \mathrm{E}+08$ & 1 & 0.00 & $2.12 \mathrm{E}+05$ \\
\hline ICP.a.Ni & 81 & 233 & 1 & 0.00 & 275 \\
\hline ICP.a.P & 1,490 & 97,700 & 1 & 0.00 & 5,460 \\
\hline ICP.a.Pb & 534 & 70,200 & 1 & 0.00 & 3,900 \\
\hline ICP.a.S & 2,610 & $4.97 \mathrm{E}+05$ & 1 & 0.00 & 11,600 \\
\hline ICP.a.Si & 1,160 & $1.19 \mathrm{E}+06$ & 1 & 0.00 & 15,000 \\
\hline ICP.a.Sr & 148 & 361 & 1 & 0.00 & 389 \\
\hline ICP.a.Ti & 59 & 84 & 1 & 0.00 & 175 \\
\hline ICP.a.Zr & 51 & 1,450 & 1 & 0.00 & 535 \\
\hline ICP.f.Ag & 46 & 534 & 1 & 0.00 & 340 \\
\hline ICP.f.Al & 95,100 & $3.12 \mathrm{E}+09$ & 1 & 0.00 & $8.05 \mathrm{E}+05$ \\
\hline ICP.f.Bi & 1,220 & 26,500 & 1 & 0.00 & 3,290 \\
\hline ICP.f.Ca & 3,670 & $1.90 \mathrm{E}+06$ & 1 & 0.00 & 21,200 \\
\hline & & & & & \\
\hline
\end{tabular}


HNF-SD-WM-ER-369 Rev. 1

Table B3-6. Concentration Estimate Statistics

(Units in $\mu \mathrm{g} / \mathrm{g}$ Except Radionuclides $[\mu \mathrm{Ci} / \mathrm{g}]$ ). (3 sheets)

\begin{tabular}{|c|c|c|c|c|c|}
\hline (4) & (1) & 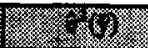 & 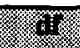 & \%or\% & \% \\
\hline ICP.f.Cd ${ }^{1}$ & 15.4 & 14.6 & 1 & 0.00 & 64 \\
\hline ICP.f.Ce ${ }^{2}$ & 79 & 1,090 & 1 & 0.00 & 498 \\
\hline ICP.f.Cr & 432 & 32,500 & 1 & 0.00 & 2,720 \\
\hline ICP.f.Fe & 33,100 & $5.70 \mathrm{E}+07$ & 1 & 0.00 & $1.29 \mathrm{E}+05$ \\
\hline ICP.f. $\mathrm{Li}^{2}$ & 3.59 & 0.422 & 1 & 0.00 & 11.8 \\
\hline ICP.f.Mg & 1,100 & 21,400 & 1 & 0.00 & 2,960 \\
\hline ICP.f.Mn & 10,400 & $5.70 \mathrm{E}+07$ & 1 & 0.00 & $1.06 \mathrm{E}+05$ \\
\hline ICP.f.Mo ${ }^{2}$ & 31.7 & 61.6 & 1 & 0.00 & 131 \\
\hline ICP.f.Na & 49,200 & $1.66 \mathrm{E}+08$ & 1 & 0.00 & $2.13 \mathrm{E}+05$ \\
\hline ICP.f.P & 1,530 & $1.79 \mathrm{E}+05$ & 1 & 0.00 & 6,900 \\
\hline ICP.f.Pb ${ }^{1}$ & 453 & 22,900 & 1 & 0.00 & 2,370 \\
\hline ICP.f.S & 2,620 & $7.23 \mathrm{E}+05$ & 1 & 0.00 & 13,400 \\
\hline ICP.f.Si & 6,980 & $6.12 \mathrm{E}+05$ & 1 & 0.00 & 16,900 \\
\hline ICP.f.Sr & 141 & 138 & 1 & 0.00 & 291 \\
\hline ICP.f.Ti & 228 & 20,700 & 1 & 0.00 & 2,050 \\
\hline ICP.f.ZI & 119 & 725 & 1 & 0.00 & 461 \\
\hline ICP.w.Al & 283 & 16,800 & 1 & 0.00 & 1,930 \\
\hline ICP.w.B & 335 & 1,060 & 1 & 0.00 & 748 \\
\hline ICP.w.Ca & 287 & 28,900 & 1 & 0.00 & 2,450 \\
\hline ICP.w.Cr & 148 & 2,770 & 1 & 0.00 & 816 \\
\hline ICP.w.Fe ${ }^{2}$ & 10.4 & 60.5 & 1 & 0.00 & 109 \\
\hline ICP.w.K & 276 & 9,410 & 1 & 0.00 & 1,510 \\
\hline ICP.w.Mg & 14.4 & 64 & 1 & 0.00 & 116 \\
\hline ICP.w.Mo & 34.7 & 169 & 1 & 0.00 & 200 \\
\hline ICP.w.Na & 49,500 & $1.23 \mathrm{E}+08$ & 1 & 0.00 & $1.90 \mathrm{E}+05$ \\
\hline ICP.w.P & 655 & 55,800 & 1 & 0.00 & 3,660 \\
\hline ICP.w.S & 2,760 & $4.90 \mathrm{E}+05$ & 1 & 0.00 & 11,600 \\
\hline ICP.w.Si & 747 & 65,800 & 1 & 0.00 & 4,010 \\
\hline IC.w.Cl & 402 & 11,800 & 1 & 0.00 & 1,780 \\
\hline IC.w.NO2 & 29,800 & $6.44 E+07$ & 1 & 0.00 & $1.32 \mathrm{E}+05$ \\
\hline
\end{tabular}


Table B3-6. Concentration Estimate Statistics (Units in $\mu \mathrm{g} / \mathrm{g}$ Except Radionuclides $[\mu \mathrm{Ci} / \mathrm{g}]$ ). (3 sheets)

\begin{tabular}{|c|c|c|c|c|c|}
\hline (2) & (. & 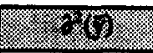 & in:- & \%" & 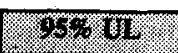 \\
\hline IC.w.NO3 & 21,200 & $3.25 \mathrm{E}+07$ & 1 & 0.00 & 93,600 \\
\hline IC.w.PO4 & 2,190 & $1.79 \mathrm{E}+05$ & $\overline{1}$ & 0.00 & 7,560 \\
\hline IC.w.SO4 & 8,550 & $5.29 \mathrm{E}+06$ & 1 & 0.00 & 37,800 \\
\hline GEA.w.Am-241.RS ${ }^{3}$ & 0.857 & 0.375 & $\bar{I}$ & 0.00 & 8.64 \\
\hline GEA.w.Co-60.RS & 0.0383 & 0.00022 & 1 & 0.00 & 0.228 \\
\hline GEA.w.Cs-137 & 32.3 & $71: 4$ & 1 & 0.00 & 140 \\
\hline GEA.w.Eu-154.RS & 1.79 & 1.47 & 1 & 0.00 & 17.2 \\
\hline GEA.w.Eu-155.RS & 2.11 & 2.22 & 1 & 0.00 & 21 \\
\hline GEA.f.gross.alpha & 0.647 & 0.0297 & 1 & 0.00 & 2.84 \\
\hline GEA.f.gross.beta & 863 & $1.54 \mathrm{E}+05$ & 1 & 0.00 & 5,840 \\
\hline $\begin{array}{l}\text { Total inorganic carbon } \\
\text { (TIC) }^{1}\end{array}$ & 5,670 & $3.96 \mathrm{E}+06$ & 1 & 0.00 & 30,900 \\
\hline $\begin{array}{l}\text { Total organic carbon } \\
\text { (TOC) }^{1}\end{array}$ & 4,590 & $2.19 \mathrm{E}+05$ & 1 & 0.00 & 10,500 \\
\hline $\begin{array}{l}\text { w.TDS. percent: total } \\
\text { dissolved solids }\end{array}$ & 0.193 & 0.00766 & 1 & 0.00 & 1.3 \\
\hline $\mathrm{Hg}^{2}$ & 23.9 & 167 & 1 & 0.00 & 188 \\
\hline CN & 11.4 & 26.1 & 1 & 0.00 & 76.3 \\
\hline w.gross.alpha ${ }^{1}$ & 0.0044 & $9.75 \mathrm{E}-07$ & 1 & 0.00 & 0.0169 \\
\hline w.gross.beta & 37.7 & 118 & 1 & 0.00 & 176 \\
\hline $\mathrm{H}-3 . \mathrm{RS}^{2,3}$ & 0.0124 & 0.00013 & 1 & 0.00 & 0.159 \\
\hline
\end{tabular}

Notes:

$L L=$ lower limits

$\mathrm{UL}=$ upper limits

${ }^{1}$ Analytes with a portion of the data below ten times the DL.

${ }^{2}$ Analytes with a portion of the data below three times the DL.

${ }^{3}$ Residual solids (RS). 
The segment recoveries for cores 53 and 54 were fair. Core 53 had recoveries of 18 percent and 59 percent for segments 1 and 2, respectively. Likewise, the recoveries for segments 1 and 2 for core 54 were 36 percent and 91 percent.

The incomplete core recovery introduces a potential for a bias in the results. If the material recovered is assumed to be a random sample of the waste, then the reported mean analyte concentration values are unbiased estimates of the true concentrations. In addition, the confidence intervals incorporate the "error" caused by the incomplete recovery. If the material recovered is not a random sample of the waste, then the results are biased. The magnitude of the bias is unknown.

Inventory estimates can be calculated for each analyte using an average density of $1.64 \mathrm{~g} / \mathrm{mL}$ and a waste volume of $371 \mathrm{~kL}(98 \mathrm{kgal})$. The $\mathrm{kg}$ estimates are the concentration estimates given in Table B3-6 multiplied by 1.64*371/1000. The Ci estimates are the concentration estimates given in Table B3-6 multiplied by $1.64 * 371$.

The model used to produce the statistical results is:

$$
y_{i j}=\mu+S_{i}+A_{i j}, i=1, \ldots a, j=1, \ldots n_{i},
$$

where

$$
\begin{array}{ll}
y_{i j} & =\quad \text { laboratory results from the } j^{\text {th }} \text { duplicate of the } i^{\text {th }} \text { core from the tank } \\
\mu & =\text { the grand mean } \\
S_{i} & =\text { the effect of the } i^{\text {th }} \text { core (spatial effect) } \\
A_{i j} & =\text { the analytical error associated with the } j^{\text {th }} \text { duplicate from the } i^{\text {th }} \text { core } \\
a & =\text { the number of cores } \\
n_{i} & =\text { the number of analytical results from the } i^{\text {th }} \text { core. }
\end{array}
$$

The variable $S_{i}$ is treated as a random effect. It is assumed that $S_{i}$ and $A_{i j}$ are each distributed normally with mean zero and variances $\sigma^{2}(S)$ and $\sigma^{2}(A)$, respectively. Estimates of $\sigma^{2}(\mathrm{~S})$ and $\sigma^{2}(\mathrm{~A})$ were obtained using Restricted Maximum Likelihood Estimation. This method applied to variance component estimation is described in Harville (1977).

The mean concentration of each analyte of interest in the tank was calculated using the following equation:

$$
\bar{y}=\frac{1}{a} \sum_{i=1}^{a} \bar{y}_{i+}=\frac{1}{a} \sum_{i=1}^{a} \frac{\sum_{j=1}^{n_{i}} y_{i j}}{n_{i}}=\frac{1}{a} \sum_{i=1}^{a} \frac{\sum_{j=1}^{n_{i}}\left(\mu+S_{i}+A_{i j}\right)}{n_{i}},
$$


where

$$
\bar{y}_{i+}=\frac{\sum_{n=1}^{b_{i}} y_{i j}}{n_{i}} .
$$

This mean gives the results from each core the same weight regardless of the unbalance that may exist for a particular analyte.

The variance of $\bar{y}$ is

$$
v(\bar{y})=C_{1} \sigma^{2}(S)+C_{2} \sigma^{2}(A)
$$

where

$$
c_{1}=\frac{1}{a}, c_{2}=\frac{1}{a^{2}} \sum_{i=1}^{a}\left(\frac{1}{n_{1}}\right)
$$

Using $\hat{\sigma}^{2}(\mathrm{~S})$ and $\hat{\sigma}^{2}(\mathrm{~A})$ (Restricted Maximum Likelihood Estimation variance component estimates), an estimated variance of $\bar{y}$ is

$$
\hat{\sigma}^{2}(y)=C_{1} \hat{\sigma}^{2}(S)+C_{2} \hat{\sigma}^{2}(A) \text {. }
$$

The degrees of freedom used for $\hat{\sigma}^{2}(\bar{y})$ is the number of cores with data minus one.

The lower and upper 95 percent confidence interval limits (95 percent lower limit and 95 percent upper limit, respectively) on the mean concentration are

$$
95 \% L L=\bar{y}-t_{0.025} \sqrt{\hat{\sigma}^{2}(\bar{y})} \text { and } 95 \% U L=\bar{y}+t_{0.025} \sqrt{\hat{o}^{2}(\bar{y})}
$$

where $t_{0.025}$ is the quantile from Student's $t$-distribution with one degree of freedom $\left(t_{0.025}=12.706\right)$ for a two-sided $95 \%$ confidence interval.

Table B3-6 gives the upper and lower limits to the 95 percent confidence intervals for analytes detected in tank 241-T-105. Some analytes had a lower confidence limit less than zero. Because an inventory value of less than zero is not possible, the lower limit is reported as zero, when it occurred. 


\section{B4.0 APPENDIX B REFERENCES}

Bell, K. E., 1993, Tank Waste Remediation System Tank Waste Characterization Plan, WHC-SD-WM-PLN-047, Rev. 1, Westinghouse Hanford Company, Richland, Washington.

De Lorenzo, D. S., J. H. Rutherford, D. J. Smith, D. B. Hiller, and K. W. Johnson, 1994, Tank Characterization Reference Guide, WHC-SD-WM-TI-648, Westinghouse Hanford Company, Richland, Washington.

DiCenso, A. T., L. C. Amato, J. D. Franklin, G. L. Nuttall, K. W. Johnson, and B. C. Simpson, 1994, Tank Characterization Report for Single-Shell Tank 241-T-105, WHC-SD-WM-ER-369, Rev. 0, Westinghouse Hanford Company, Richland, Washington.

Dukelow, G. T., J. W. Hunt, H. Babad, and J. E. Meacham, 1995, Tank Safety Screening Data Quality Objective, WHC-SD-WM-SP-004, Rev. 2, Westinghouse Hanford Company, Richland, Washington.

Giamberardini, K. K., 1993, 222-S Laboratories Single-Shell Tank Waste Characterization, Tank T-105 Core 57 Data Package, WHC-SD-WM-DP-040, Rev. 0, Westinghouse Hanford Company, Richland, Washington.

Godfrey, W. L., 1965, 242-T Evaporator Feed (internal letter to S. J. Beard, September 24, 1965), General Electric Company, Richland, Washington.

Harville D. A., 1977, "Maximum Likelihood Approaches to Variance Component Estimation and to Related Problems," Journal of the American Statistical Association, pp 320-340.

Herting, D. L. 1993, Mass/Charge Balance for Tank T-105, (internal memorandum 12110-PCL93-084 to K. L. Kocher, dated September 28), Westinghouse Hanford Company, Richland, Washington.

Kocher, K. L., 1994, WHC 222-S and PNL Laboratories Single Shell Tank Waste Characterization, Tank T-105 Cores 53 and 54 Data Packages (Narrative) and Validation Summaries, WHC-SD-WM-DP-047, Rev. 0-B, Westinghouse Hanford Company, Richland, Washington. 
Silvers, K. L., and L. M. Sasaki, 1993, Letter of Instruction for Tank T-105 Analysis Priorities, (internal memorandum 7K220-93-022 to K. L. Kocher, April 20), Westinghouse Hanford Company, Richland, Washington.

Wheeler, R. E., 1974. Analysis of Tank Farm Samples - Sample: T-4927, 105-T, (Letter to R. L. Walser, September 17), Atlantic Richfield Hanford Company, Richland, Washington. 
HNF-SD-WM-ER-369 Rev. 1

This page intentionally left blank. 
HNF-SD-WM-ER-369 Rev. 1

APPENDIX C

STATISTICAL ANALYSIS FOR ISSUE RESOLUTION

C-1 
HNF-SD-WM-ER-369 Rev. 1

This page intentionally left blank.

C-2 


\section{APPENDIX C}

\section{STATISTICAL ANALYSIS FOR ISSUE RESOLUTION}

Statistical analyses for issue resolution were not performed to determine the upper 95 percent confidence interval for total alpha and DSC exothermic results. This was because of the poor sample recovery and low levels of alpha and DSC found in the samples. Only one exotherm was found that approached the DQO limit; all other exotherms were lower by a factor of ten or more. Results are included in Section 2.0. 
HNF-SD-WM-ER-369 Rev. 1

This page intentionally left blank. 
HNF-SD-WM-ER-369 Rev. 1

\begin{abstract}
APPENDIX D
EVALUATION TO ESTABLISH BEST-BASIS INVENTORY FOR SINGLE-SHELL TANK 241-T-105
\end{abstract}

D-1 
HNF-SD-WM-ER-369 Rev. 1

This page intentionally left blank.

\section{D-2}




\section{APPENDIX D}

\section{EVALUATION TO ESTABLISH BEST-BASIS INVENTORY FOR SINGLE-SHELL TANK 241-T-105}

The following evaluation provides a best-basis inventory estimate for chemical and radionuclide components in tank 241-T-105.

\section{D1.0 IDENTIFY/COMPILE INVENTORY SOURCES}

Characterization results from the most recent sampling event for this tank are in Appendix B. These results are based on two core samples (cores 53 and 54) obtained in 1993. Waste recovery was incomplete for both cores. As a result, the estimated sample inventories are based only on segment 1 of the 2 segment core samples. The solids recovery for segment 2 was especially low. Analyses indicate the waste is strongly heterogeneous. The HDW model document (Agnew et al. 1996a) provides tank content estimates, derived from the LANL model, in terms of component concentrations and inventories.

\section{D2.0 COMPARE COMPONENT INVENTORY VALUES AND NOTE SIGNIFICANT DIFFERENCES}

Sampling-based inventories derived from the analytical concentration data (see Section B3.4), and HDW model inventories generated by the LANL HDW model (Agnew et al. 1996), are compared in Tables D2-1 and D2-2. The tank volume used to generate these inventories is $371 \mathrm{~kL}$ (98 kgal). This volume which is reported in Hanlon (1996) is the same as that reported by Agnew et al. (1996a). The density used to calculate the sampling inventory estimate is $1.64 \mathrm{~g} / \mathrm{mL}$, based on sample measurements, which is higher than the value reported in Agnew et al. (1996a). The HDW model density is estimated to be $1.24 \mathrm{~g} / \mathrm{mL}$. Note the significant differences between the sampling-based and HDW model inventories for several bulk components, for example, $\mathrm{Al}, \mathrm{Bi}, \mathrm{Mn}$. This indicates the sample represents $\mathrm{CW}$ waste and probably does not represent the $2 \mathrm{C}$ waste type. 
HNF-SD-WM-ER-369 Rev. 1

Table D2-1. Sample- and Historical Tank Content-Based Inventory Estimates for Nonradioactive Components in Tank 241-T-105. (2 sheets)

\begin{tabular}{|c|c|c|c|}
\hline 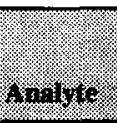 & 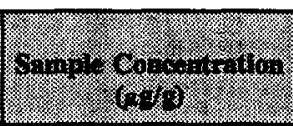 & 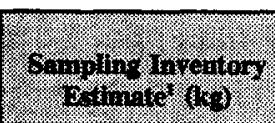 & 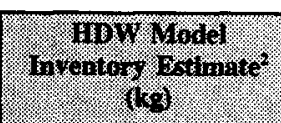 \\
\hline $\mathrm{Ag}$ & 46 & 28 & $\mathrm{nr}$ \\
\hline Al & 95,100 & 58,000 & 2,300 \\
\hline B & 335 & 200 & $\mathrm{nr}$ \\
\hline $\mathrm{Bi}$ & 1,330 & 810 & 6,200 \\
\hline $\mathrm{Ca}$ & 3,670 & 2,200 & 1,800 \\
\hline $\mathrm{Cd}$ & 15.4 & 9.4 & $\mathrm{nr}$ \\
\hline $\mathrm{Cl}$ & 402 & 240 & 300 \\
\hline $\mathrm{Cr}$ & 505 & 310 & 69 \\
\hline$F$ & $1.26^{3} \mu \mathrm{g} / \mathrm{mL}$ & 0.5 & 1,200 \\
\hline $\mathrm{Fe}$ & 33,100 & 20,000 & 9,500 \\
\hline $\mathrm{Hg}$ & 23.9 & 14 & 1.1 \\
\hline $\mathbf{K}$ & 305 & 190 & 65 \\
\hline $\mathrm{La}$ & 24.3 & 16 & 0 \\
\hline $\mathrm{Mn}$ & 11,600 & 7,000 & 0 \\
\hline $\mathrm{Na}$ & 56,300 & 30,000 & 34,000 \\
\hline $\mathrm{Ni}$ & 81 & 49 & 28 \\
\hline $\mathrm{NO}_{2}$ & 29,800 & $18,000^{3}$ & 1,100 \\
\hline $\mathrm{NO}_{3}$ & 21,200 & $13,000^{3}$ & 19,000 \\
\hline $\mathrm{OH}$ & $\mathrm{nr}$ & $<760$ & 13,000 \\
\hline $\mathrm{Pb}$ & 453 & 280 & 0 \\
\hline $\mathrm{P}$ as $\mathrm{PO}_{4}$ & 4,690 & 2,800 & 3,400 \\
\hline$\overline{\mathrm{Si}}$ & 6,980 & 4,200 & 740 \\
\hline $\mathrm{S}$ as $\mathrm{SO}_{4}$ & 7,860 & 4,800 & 1,500 \\
\hline $\mathrm{Sr}$ & 141 & 85 & 0 \\
\hline
\end{tabular}


Table D2-1. Sample- and Historical Tank Content-Based Inventory Estimates for Nonradioactive Components in Tank 241-T-105. (2 sheets)

\begin{tabular}{|c|c|c|c|}
\hline Am & 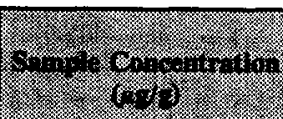 & 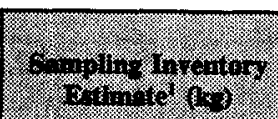 & 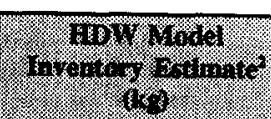 \\
\hline TIC as $\mathrm{CO}_{3}$ & $28,400^{3}$ & 17,200 & 2,600 \\
\hline TOC & 4,590 & 2,800 & 0 \\
\hline$U_{\text {towal }}$ & 9,140 & 5,600 & 20 \\
\hline $\mathrm{Zr}$ & 119 & 72 & 63 \\
\hline $\mathrm{H}_{2} \mathrm{O}(\mathrm{wt} \%)$ & 44 & 44 & 72 \\
\hline Density $(\mathrm{kg} / \mathrm{L})$ & 1.64 & 1.64 & 1.24 \\
\hline
\end{tabular}

Notes:

$\mathbf{n r}=$ not reported

'DiCenso et al. (1994)

${ }^{2}$ Appendix E of Agnew et al. (1996a)

${ }^{3}$ Based on analysis of water leach only. 
HNF-SD-WM-ER-369 Rev. 1

Table D2-2. Sample- and Historical Tank Content-Based Inventory Estimates for Radioactive Components in Tank 241-T-105. ${ }^{1}$

\begin{tabular}{|c|c|c|c|}
\hline 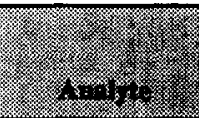 & 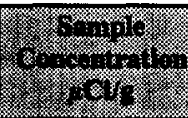 & 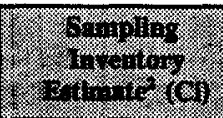 & 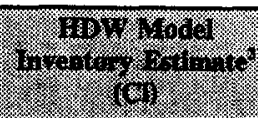 \\
\hline${ }^{241} \mathrm{Am}$ & 0.857 & 520 & $\mathrm{nr}$ \\
\hline${ }^{125} \mathrm{Sb}$ & 0.665 & 400 & $\mathrm{nr}$ \\
\hline${ }^{14} \mathrm{C}^{4}$ & 0.001 & 0.61 & $\mathrm{nr}$ \\
\hline${ }^{134} \mathrm{Cs}$ & $<0.055$ & $<33.5$ & $\mathrm{nr}$ \\
\hline${ }^{137} \mathrm{Cs}$ & 43.9 & 30,000 & 2,930 \\
\hline${ }^{60} \mathrm{Co}$ & 0.038 & 23 & $\mathrm{nr}$ \\
\hline${ }^{154} \mathrm{Eu}$ & 1.79 & 1,100 & $\mathrm{nr}$ \\
\hline${ }^{155} \mathrm{Eu}$ & 2.11 & 1,300 & $\mathrm{nr}$ \\
\hline${ }^{238} \mathrm{Pu}$ & $2.45 \mathrm{E}-4$ & $<0.149$ & $\mathrm{nr}$ \\
\hline${ }^{239 / 240} \mathrm{Pu}$ & 0.138 & 84 & 6.1 \\
\hline${ }^{90} \mathrm{Sr}$ & 280 & 1.7E+05 & 28 \\
\hline${ }^{99} \mathrm{Tc}^{4}$ & 0.372 & 230 & $\mathrm{nr}$ \\
\hline${ }^{3} \mathrm{H}$ & 0.012 & 7.6 & $\mathrm{nr}$ \\
\hline Total alpha & 0.65 & 393 & $\mathrm{nr}$ \\
\hline Total beta & 860 & $5.2 \mathrm{E}+05$ & $\mathrm{nr}$ \\
\hline
\end{tabular}

Notes:

$\mathrm{nr}=$ not reported

${ }^{1}$ Curie values decayed to January 1,1994

${ }^{2}$ DiCenso et al. (1994)

${ }^{3}$ Appendix E of Agnew et al. (1996a)

${ }^{4}$ Based on analysis of water leach only. 


\section{D3.0 REVIEW AND EVALUATION OF COMPONENT INVENTORIES}

The following evaluation of tank contents was performed to identify potential errors and/or missing information that would influence the sampling-based and HDW model component inventories.

\section{D3.1 CONTRIBUTING WASTE TYPES}

The following abbreviations were used to designate waste types:

$\begin{array}{lll}1 \mathrm{C} & = & \text { first decontamination cycle } \mathrm{BiPO}_{4} \text { waste } \\ 2 \mathrm{C} & = & \text { second decontamination cycle } \mathrm{BiPO}_{4} \text { waste } \\ \mathrm{RCW} & = & \mathrm{REDOX} \text { process aluminum cladding waste } \\ \mathrm{CW} & = & \mathrm{BiPO}\end{array}$

Tank 241-T-105 is the middle tank in a cascade that includes tanks 241-T-104 and 241-T-106. In 1946, tank 241-T-105 began receiving 2C waste (Anderson 1990, Agnew et al. 1996b). The waste was sent directly from T Plant to tank 241-T-105, bypassing tank 241-T-104. The 2C waste cascaded from tank 241-T-105 to 241-T-106 when tank 241-T-105 was full.

In 1948, the cascade line from tank 241-T-104 to tank 241-T-105 was used to transfer $1 \mathrm{C}$ waste from tank 241-T-104. This 1C waste was combined with cladding waste from the removal of $\mathrm{Al}$ fuel element cladding. The cladding waste comprised about 7 percent of the $1 \mathrm{C} / \mathrm{CW}$ waste stream. The cascade from tank 241-T-104 to tank 241-T-105 was used for transfer of $1 \mathrm{C} / \mathrm{CW}$ waste until the last additions of $1 \mathrm{C} / \mathrm{CW}$ waste from $\mathrm{T}$ Plant in 1954 . In 1954, supernatant in tank 241-T-105 was transferred to cribs.

Beginning in 1955 and until 1956, only CW was sent directly to tank 241-T-105. This waste settled in the tank until 1967 when the supernate was transferred to cribs. Agnew et al. (1996a) defines the origin of the cladding waste from the REDOX process (RCW), whereas Anderson (1990) targets the cladding waste as $\mathrm{CW}$ from the $\mathrm{BiPO}_{4}$ process. Further evaluation of waste transaction records in Agnew et al. (1996b) suggests $\mathrm{BiPO}_{4} \mathrm{CW}$ was added rather than $\mathrm{RCW}$. However, the measurable difference between the two types of cladding waste is probably negligible.

In 1967, tank 241-T-105 was filled with dilute 300 Area laboratory waste. Much of the supernatant in tank 241-T-105 was sent to the 242-T Evaporator in 1967 and 1968. 
Additional dilute wastes were sent to tank 241-T-105 from 1968 to 1973 . These waste types probably did not contribute significantly to the tanks' solids volume. These wastes consisted of decontamination waste from $\mathrm{T}$ Plant, some supernate transferred from other single-shell tanks, and B Plant low-level waste and ion exchange waste. In 1974, most of the supernate was transferred from tank 241-T-105.

Based on this process history, it is expected that $2 \mathrm{C}$ waste fills the tank bottom. The 1C waste makes up another layer. The records indicate that cladding waste may reside above the 1C waste. As summarized below, Anderson (1990) and Hill et al. (1995) predict that some cladding waste is present in tank 241-T-105 (not mixed with 1C waste). However, Agnew et al. (1996a) predicts the presence of only 1C and 2C waste, claiming the majority of the cladding waste solids were transferred to cribs along with the supernatant in 1967.

\section{Expected Solids in Waste}

Anderson (1990), SORWT (Hill et al. 1995): 1C, 2C, CW

Agnew et al. (1996a), Agnew et al. (1996b): 1C, 2C

\section{Model-Based Predicted Current Inventory (Agnew et al. 1996a)}

$\begin{array}{cc}\text { Waste Type } & \text { Waste Volume kL (kgal) } \\ 1 \mathrm{C} 2 & 98(26) \\ 2 \mathrm{C} 2 & 273(72)\end{array}$

The analytical results for tank 241-T-105 indicate much higher concentrations of aluminum and lower concentrations of bismuth in the waste solids than would be predicted from waste that contained only $1 \mathrm{C}$ and $2 \mathrm{C}$ waste from the $\mathrm{BiPO}_{4}$ process. These results suggest a significant proportion of the waste that was sampled consists of cladding waste which contains the precipitated aluminum resulting from neutralization of the dissolved aluminum fuel cladding. The analysis provides evidence that CW exists in tank 241-T-105. Agnew et al. (1996a) does not predict any CW beyond that mixed with the $1 \mathrm{C}$ waste in the tank.

The waste transaction record (Agnew et al. 1996b) shows that $980 \mathrm{~kL}$ (259 kgal) of cladding waste was introduced into the tank during 1955 and 1956. Although the transaction records show that this waste was removed in 1967 , it is likely that a significant portion of the precipitated solids remained on the waste surface. If it is assumed the solids content of the neutralized waste is 7 volume percent, a maximum of approximately $79 \mathrm{~kL}(21 \mathrm{kgal})$ of CW could remain in the tank. As noted earlier, these cladding waste solids are expected to originate from the $\mathrm{BiPO}_{4}$ process rather than the REDOX process. 


\section{D3.2 EVALUATION OF TECHNICAL FLOWSHEET INFORMATION}

Waste compositions from flowsheets for $1 \mathrm{C}, 2 \mathrm{C}$, and $\mathrm{CW}$ waste streams are provided in Table D3-1. The comparative LANL defined $1 \mathrm{C}$ and $2 \mathrm{C}$ waste streams from Agnew et al. (1996a) are also provided in this table. Agnew et al. (1996a) does not indicate CW waste in tank 241-T-105. As shown in Table D3-1, the aluminum concentration in the $1 \mathrm{C2}$ defined waste stream (Agnew et al. 1996a) is approximately a factor of three higher than the flowsheet composition. Based on information in Schneider (1951) it is thought that the 1C waste stream contained approximately 7 volume percent cladding waste, which is about a third of that estimated in Agnew et al. (1996a).

Table D3-1. Technical Flowsheet and Los Alamos National Laboratory Defined Waste Streams.

\begin{tabular}{|c|c|c|c|c|c|}
\hline (-. & 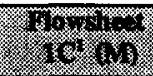 & 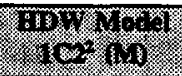 & 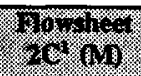 & 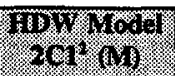 & 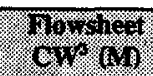 \\
\hline $\mathrm{NO}_{3}$ & 1.44 & 0.588 & 0.987 & 1.24 & 0.73 \\
\hline $\mathrm{NO}_{2}$ & 0.058 & 0.174 & 0 & 0 & 0.82 \\
\hline $\mathrm{SO}_{4}$ & 0.063 & 0.0616 & 0.06 & 0.05 & 0 \\
\hline $\mathrm{PO}_{4}$ & 0.258 & 0.334 & $\overline{0.241}$ & 0.21 & 0 \\
\hline $\mathrm{F}$ & 0.170 & $\overline{0.228}$ & 0.154 & 0.22 & 0 \\
\hline $\mathrm{Bi}$ & 0.012 & 0.014 & 0.00623 & 0.01 & 0 \\
\hline$\overline{F e}$ & 0.032 & 0.046 & 0.03 & 0.04 & 0 \\
\hline$\overline{\mathrm{Si}}$ & 0.031 & 0.038 & 0.0257 & 0.037 & 0.041 \\
\hline$\overline{\mathrm{U}}$ & 0.00096 & 0.0007 & $2.4 \mathrm{E}-5$ & 0.0001 & 0.0072 \\
\hline $\mathrm{Cr}^{+3 /+6}$ & 0.0033 & 0.0052 & 0.00123 & 0.0042 & 0 \\
\hline $\mathrm{Ce}$ & 0.00019 & 0 & 0 & 0 & 0 \\
\hline $\mathrm{Na}$ & 2.17 & 2.17 & 1.59 & 2.27 & 3.79 \\
\hline$\overline{\mathrm{K}}$ & 0 & 0.0034 & & & \\
\hline$\overline{\mathrm{Hg}}$ & 0 & $2 \mathrm{E}-05$ & 0 & 0 & 0 \\
\hline$\overline{Z r}$ & 0.0003 & 0.004 & 0 & 0 & 0 \\
\hline$\overline{\mathrm{Al}}$ & 0.083 & 0.233 & 0 & 0 & 1.17 \\
\hline
\end{tabular}

Notes:

'Schneider (1951); assumes $1 \mathrm{C}$ waste contains approximately 7 percent $\mathrm{CW}$.

${ }^{2}$ Appendix B of Agnew et al. (1996a); assumes 1C waste contains approximately 24 percent CW.

${ }^{3}$ Schneider (1951). 


\section{D3.3 ASSUMPTIONS FOR RECONCILING WASTE INVENTORIES}

Reference inventories of components in tank 241-T-105 were estimated using an independent assessment that is based on a set of simplified assumptions. The predicted inventories were then compared with the tank 241-T-105 sampling-based inventories and the HDW model inventories. The assumptions and observations for the engineering assessment were based on best technical judgement pertaining to parameters that can significantly influence tank inventories. These parameters include: (1) correct prediction of contributing waste types and correct relative proportions of the waste types; (2) accurate predictions of model flowsheet conditions, fuel processed, and waste volumes; (3) accurate prediction of partitioning of components; (4) accurate predictions of physical parameters such as density, percent solids, void fraction (porosity), etc.

Using this evaluation, the assumptions/bases can be modified as necessary to provide a means for identifying and reconciling potential errors and/or missing information that could influence the sampling- and model-based inventories. The simplified assumptions and observations used for the evaluation are listed below. The derivation of these assumptions and observations are provided in subsequent paragraphs.

1. Because of the biased analytical data for tank 241-T-105, tanks 241-T-104 and 241-B-111, which contain only one waste type (1C and 2C, respectively), helped provide the analytical basis for inventories for the $1 \mathrm{C}$ and $2 \mathrm{C}$ waste types. Tank 241-U-204 provides the basis for $\mathrm{CW}$.

2. The $1 \mathrm{C}, 2 \mathrm{C}$, and $\mathrm{CW}$ waste streams contributed to solids formation. The $1 \mathrm{C}$ waste stream contained 7 volume percent of $\mathrm{CW}$ from the $\mathrm{BiPO}_{4}$ process. The relative proportions of $1 \mathrm{C}, 2 \mathrm{C}$, and $\mathrm{CW}$ used for comparison were, respectively, $216 \mathrm{~kL}$ (57 kgal) $2 \mathrm{C}, 76 \mathrm{~kL}$ (20 kgal) $1 \mathrm{C}$, and $79 \mathrm{~kL}$ (21 kgal) CW.

3. The components listed in the technical flowsheets summarized in Table D3-1 were used for the evaluation.

4. Tank waste mass is calculated using the tank volume listed in Hanlon (1996). Both the anaiytical-based and the model-based inventories use equivalent volumes of $371 \mathrm{~kL}$ (98 kgal). As a result, inventory comparisons are made on the same total volume basis.

5. All $\mathrm{Bi}, \mathrm{Fe}, \mathrm{Al}, \mathrm{Si}, \mathrm{Ce}$, and $\mathrm{U}$ precipitate as water insoluble components based on analytical data for tanks 241-B-111, 241-T-104 and 241-U-204. The HDW model predicts varying solubilities for these components. 
6. The precipitated solids are concentrated by a factor of 10 in $1 \mathrm{C}$ waste (equivalent to 10 volume percent solids) and 20 for $2 \mathrm{C}$ waste (equivalent to 5 volume percent solids) and 8 for $\mathrm{CW}$ (equivalent to 16 volume percent solids). The concentration factors (CFs) for $1 \mathrm{C}$ and $2 \mathrm{C}$ waste are based on inventory evaluations for tanks 241-T-104 and 241-B-111, respectively. The CF for CW is based on the inventory evaluation for tank 241-U-204.

7. Sodium, $\mathrm{NO}_{3}, \mathrm{NO}_{2}, \mathrm{PO}_{4}, \mathrm{SO}_{4}, \mathrm{Cr}$, and $\mathrm{F}$ partition between the liquid and solid phases. This assumption is based on the behavior of these components in tanks 241-T-104, 241-B-111, and 241-U-204.

8. No radiolysis of $\mathrm{NO}_{3}$ to $\mathrm{NO}_{2}$ and no additions of $\mathrm{NO}_{2}$ to the waste for corrosion purposes are factored into this independent assessment.

\section{D3.4 VOLUME RATIO OF WASTE TYPES}

The HDW model predicts $98 \mathrm{~kL}(26 \mathrm{kgal})$ of $1 \mathrm{C}$ waste and $273 \mathrm{~kL}$ ( $72 \mathrm{kgal})$ of $2 \mathrm{C}$ waste in tank 241-T-105. As noted earlier, analytical information indicates that $\mathrm{BiPO}_{4}$ process $\mathrm{CW}$ also may comprise a portion of the total waste. Because all three waste types $(1 \mathrm{C}, 2 \mathrm{C}$, and CW) in tank 241-T-105 contain common chemical constituents, it is difficult to predict the relative proportion of the waste types, particularly considering the bias of the analytical data. For this assessment, the volume of $1 \mathrm{C}$ and $2 \mathrm{C}$ waste in the tank was determined by multiplying the ratios predicted by Agnew et al. (1996a) for $1 \mathrm{C}$ and $2 \mathrm{C}$ waste (27 volume percent $1 \mathrm{C}, 73$ volume percent $2 \mathrm{C}$ ), by the total volume of waste in the tank, less $79 \mathrm{~kL}$ (21 kgal) attributed to $\mathrm{CW}$ waste (ie. $371-79 \mathrm{~kL}$ ). The resulting assumed volumes for each waste type are provided in Assumption 2 of Section D3.3.

\section{D3.5 METHODOLOGY FOR ESTIMATING TANK 241-T-105 INVENTORY}

The sample-based inventories for tank 241-T-105 do not represent the entire tank contents. In addition, the process history for this tank is not adequately defined to enable an estimate of waste component inventories. However, the known waste types in tank 241-T-105 (1C, $2 \mathrm{C}$, and $\mathrm{CW}$ ) have been sufficiently characterized in other tanks to enable this information to be used as a basis for predicting the inventory in tank 241-T-105. Thus, inventories calculated for tanks 241-T-104 (1C waste), 241-B-111 (2C waste), and 241-U-204 (CW waste), provided the basis for most of the tank 241-T-105 estimates.

Caution should be taken when assuming that the chemical composition for a particular waste type in one tank can be used for that waste type in other tanks. Although this assumption has been shown to be valid for some tanks, particularly for those in a cascade arrangement, component concentrations in a particular waste type may not always be comparable to other waste tanks because of the large variation in the waste volumes flowing through the tanks, variations in solids and liquid ratios resulting from cascade and cribbing procedures, and the 
potential for chemical reactions (for example, metathesis) of components when mixed/diluted with other waste types. However, without suitable analytical data and/or process history records for tank 241-T-105, this method was used as the basis for predicting the tank inventory.

The inventories in tanks 241-T-104, 241-B-111, and 241-U-204 were estimated using two approaches. The first approach uses process history knowledge. The inventories for tank components were predicted based on knowledge of the process flowsheets that generated the waste streams, and the total throughput of the waste to the tank. Using this process history method, inventories in waste solids were estimated for components that are expected to precipitate 100 percent from solution (for example, $\mathrm{Bi}, \mathrm{Fe}, \mathrm{Si}$ ).

Another method for predicting a component inventory for a particular waste type in a tank (for example, 1C waste) is to derive a concentration factor for that component. This approach also was used to estimate inventories in tanks 241-T-104, 241-B-111, and 241-U-204. The CF is derived by dividing the concentration of a component found in the tank samples by the concentration of that component in the neutralized process waste stream (that is, flowsheet concentrations in Table D3-1). The CF for components of a defined waste are best determined if the tank contains only one waste type (for example, only $1 \mathrm{C}$ waste in tank 241-T-104) or when abundant representative analytical data are available. Components expected to precipitate 100 percent based on chemical knowledge should exhibit nearly the same CFs. The relative concentration of fully precipitated components in the waste solids are in proportion to the respective flow sheet concentration for those components. If this is the case, it can generally be concluded that the analytical data represent tank contents.

After the CFs for fully precipitated components for a waste type are determined, the sample analysis can be used to establish how other components such as $\mathrm{Cr}, \mathrm{SO}_{4}$, or $\mathrm{PO}_{4}$ partition between solids and supernatants. For example, if the $\mathrm{CF}$ for $\mathrm{Bi}, \mathrm{Fe}$, and $\mathrm{Si}$ are determined to be approximately 10 for $1 \mathrm{C}$ waste, and the $\mathrm{CF}$ for $\mathrm{PO}_{4}$ is 4.0 , then it can be concluded that 40 percent of the $\mathrm{PO}_{4}$ in the neutralized process waste partitions to the waste solids, that is, the partitioning factor (PF) is 0.4 .

When the process history method and CF method are applied to tanks 241-T-104, 241-B-111, and 241-U-204, they provide consistent inventory predictions and conclude that the sample analyses provide the best inventory basis for these tanks. Based on tank sample data, the derived CFs and PFs for tank 241-T-104, 241-B-111 and 241-U-104 are shown in Table D3-2. The following calculations provide estimates of tank 241-T-105 inventories based on these factors. 
Table D3-2. Concentration Factors and Partitioning Factors for $1 \mathrm{C}, 2 \mathrm{C}$, and $\mathrm{CW}$ Waste Types.

\begin{tabular}{|c|c|c|c|c|c|c|}
\hline \multirow[b]{2}{*}{ 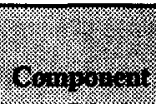 } & \multicolumn{3}{|c|}{ 2. } & \multicolumn{3}{|c|}{ Rin } \\
\hline & - & 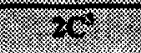 & 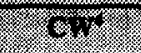 & r্য & 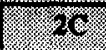 & 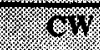 \\
\hline $\mathbf{B i}$ & 10 & 20 & na & 1 & 1 & na \\
\hline $\mathrm{Fe}$ & 10 & 20 & na & 1 & 1 & na \\
\hline $\mathrm{Si}$ & 10 & 20 & 6 & 1 & 1 & 1 \\
\hline U & 10 & 20 & 6 & 1 & 1 & 1 \\
\hline $\mathrm{Cr}$ & 6.7 & 20 & na & 0.67 & 1 & na \\
\hline $\mathrm{Ce}$ & 10 & na & na & na & na & na \\
\hline $\mathrm{Al}$ & 10 & na & 6 & 1 & na & 1 \\
\hline $\mathbf{Z r}$ & 10 & na & na & 1 & na & na \\
\hline $\mathrm{Na}$ & 1.6 & 3.1 & 1.2 & 0.16 & 0.15 & 0.2 \\
\hline $\mathrm{SO}_{4}$ & 0.8 & 4.3 & na & 0.08 & 0.22 & na \\
\hline $\mathrm{PO}_{4}$ & 4 & 2.5 & na & 0.40 & 0.13 & na \\
\hline $\bar{F}$ & 3.4 & 0.83 & na & 0.34 & 0.03 & na \\
\hline $\mathrm{NO}_{3}$ & 0.83 & 1.6 & 1.2 & 0.08 & 0.08 & 0.2 \\
\hline $\mathrm{NO}_{2}$ & 2.0 & na & 1.2 & 0.20 & na & 0.2 \\
\hline
\end{tabular}

Notes:

$\mathrm{na}=$ not applicable

'Fraction of flowsheet component precipitating in waste solids. Includes interstitial liquors associated with solids.

${ }^{2}$ Based on tank 241-T-104

${ }^{3}$ Based on tank 241-B-111

${ }^{4}$ From RCW tank 241-U-204 


\section{D3.6 ESTIMATED INVENTORY OF COMPONENTS}

The following calculations provide estimates of tank 241-T-105 inventories for components.

\section{Components Assumed to Precipitate 100 percent.}

Bi: $\quad\left[.00623\right.$ moles $\mathrm{Bi} / \mathrm{L}_{2 \mathrm{C}} \times 57 \mathrm{kgal} \times 20_{\mathrm{CP} 2 \mathrm{C}}+0.012$ moles $\mathrm{Bi} / \mathrm{L}_{1 \mathrm{c}} \times$ $\left.20 \mathrm{kgal} \times 10_{\mathrm{CF}(\mathrm{COC})}\right] \times[3,785 \mathrm{~L} / \mathrm{kgal} \times 209 \mathrm{~g} / \mathrm{mole} \mathrm{Bi} \times \mathrm{MT} / 1 \mathrm{E}+06]$ $=7.5 \mathrm{MT}$

Fe: $\quad\left[0.032\right.$ moles Fe/ $/ \mathrm{L}_{1 \mathrm{C}} \times 20 \mathrm{kgal} \times 10_{\mathrm{CP} 1 \mathrm{C} C}+0.03$ moles $\mathrm{Fe} / \mathrm{L}_{2 \mathrm{C}} \times$ $\left.57 \mathrm{kgal} \times 20_{\mathrm{Cr}(\mathrm{CO}}\right] \times[3,785 \mathrm{~L} / \mathrm{gal} \times 55.85 \mathrm{~g} /$ mole Fe $\times \mathrm{MT} / 1 \mathrm{E}+06$ $=8.6 \mathrm{MT}$

Similarly:

$\begin{array}{ll}\text { Si: } & 4.3 \mathrm{MT} \\ \mathrm{Zr}: & 0.021 \mathrm{MT} \\ \mathrm{Ce}: & 0.020 \mathrm{MT} \\ \mathrm{U}: & 1.0 \mathrm{MT} \\ \mathrm{Al}: & 17 \mathrm{MT}\end{array}$

\section{Components Assumed to Partition Between Aqueous and Solid Phases}

Na: $\quad\left[2.17\right.$ moles Na/ $\mathrm{L}_{1 \mathrm{c}} \times 20 \mathrm{kgal} \times 10_{\mathrm{CF}} \times 0.16 \mathrm{PF}+1.59$ moles $\mathrm{Na} / \mathrm{L}_{2 \mathrm{c}} \times 57 \mathrm{kgal} \times 2.0 \mathrm{CF} \times 0.15 \mathrm{PF}+3.79$ moles Na/L $\mathrm{L}_{\mathrm{cw}} \times$ $21 \mathrm{kgal} \times 6 \mathrm{CF} \times 0.2 \mathrm{PF}] 3,785 \mathrm{~L} / \mathrm{kgal} \times 23 \mathrm{~g} /$ mole Na $\times$ $\mathrm{MT} / 1.0 \mathrm{E}+06 \mathrm{~g}=38 \mathrm{MT}$

Similarly:

$\begin{array}{ll}\text { Cr: } & 0.36 \mathrm{MT} \\ \mathrm{SO}_{4}: & 5.8 \mathrm{MT} \\ \mathrm{PO}_{4}: & 20 \mathrm{MT} \\ \mathrm{F}: & 1.2 \mathrm{MT} \\ \mathrm{NO}_{3}: & 31 \mathrm{MT} \\ \mathrm{NO}_{2}: & 4.0 \mathrm{MT}\end{array}$

Estimated component inventories from this evaluation are compared with the sample from tank 241-T-105 and HDW model-based inventories in Table D3-3. Observations regarding these inventories are noted, by component, in the following text. 
Bismuth. The reference inventory predicted by this assessment is comparable to the HDW model-based inventory. The sample-based inventory is derived from incomplete sample recovery. It does not represent the entire tank content and is probably biased towards CW. The $1 \mathrm{C}$ and $2 \mathrm{C}$ defined wastes from the HDW model do not differ significantly from the $1 \mathrm{C}$ and $2 \mathrm{C}$ flowsheet basis (see Table D3-1). The HDW model assumes that significantly less $\mathrm{Bi}$ in the $1 \mathrm{C} 2$ and $2 \mathrm{Cl}$ stream precipitated (approximately 70 percent) than is assumed for the comparable waste streams for this independent assessment. However, the HDW model predicts a larger volume of $2 \mathrm{C}$ waste in this tank. Consequently the predicted inventories for the HDW model and this assessment are comparable.

Table D3-3. Comparison of Selected Component Inventory Estimates for Tank 241-T-105 Waste.

\begin{tabular}{|c|c|c|c|}
\hline Compor w & W & 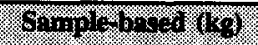 & TIM \\
\hline $\mathbf{B i}$ & 7,500 & 740 & 6,200 \\
\hline $\mathrm{Cr}$ & 360 & 260 & 69 \\
\hline $\mathrm{Fe}$ & 8,600 & 20,000 & 9,500 \\
\hline $\mathbf{K}$ & 0 & 190 & 65 \\
\hline $\mathrm{Al}$ & 17,000 & 58,000 & 2,300 \\
\hline Mn & 0 & 6,300 & 0 \\
\hline $\mathrm{Na}$ & 38,000 & 30,000 & 34,000 \\
\hline $\mathrm{Si}$ & 4,300 & 4,200 & 740 \\
\hline$\overline{\mathrm{Zr}}$ & 21 & 72 & 63 \\
\hline$\overline{\mathrm{U}}$ & 1,000 & $\mathrm{nr}$ & 20 \\
\hline$F$ & 1,200 & 0.51 & 1,200 \\
\hline $\mathrm{NO}_{3}$ & 31,000 & $13,000^{t}$ & 19,000 \\
\hline $\mathrm{NO}_{2}$ & 4,000 & $18,000^{1}$ & 1,100 \\
\hline $\mathrm{PO}_{4}$ & 20,000 & 2,900 & 3,400 \\
\hline $\mathrm{SO}_{4}$ & 5,800 & 4,800 & 1,500 \\
\hline $\mathrm{H}_{2} \mathrm{O}(\%)$ & & 44 & 76,000 \\
\hline
\end{tabular}

Note:

'Based on analysis of water leach only 
Chromium. This inventory assessment predicted the total $\mathrm{Cr}$ content to be close to that based on the sample analysis. However, these values are approximately four-fold higher than that predicted by the HDW model. The HDW model-defined waste streams indicate slightly higher concentrations of chromium in the $1 \mathrm{C}$ and $2 \mathrm{C}$ wastes than given in Schneider (1951) (see Table D3-1). These concentrations may be somewhat inflated from the corrosion source-terms assumed for the HDW model; no corrosion source term was used in this assessment. However, the $\mathrm{HDW}$ model assumes that no $\mathrm{Cr}$ precipitated in the $1 \mathrm{C}$ and $2 \mathrm{C}$ stream; that is, the only $\mathrm{Cr}$ contribution to the solids is from the interstitial liquids associated with the solids. Because the $\mathrm{Cr}$ was added primarily as $\mathrm{Cr} \mathrm{III}$ in the $\mathrm{BiPO}_{4}$ process, it is expected that the majority of the chromium will precipitate as $\mathrm{Cr}(\mathrm{OH})_{3}$ or $\mathrm{Cr}_{2} \mathrm{O}_{3} \cdot \mathrm{XH}_{2} \mathrm{O}$. The presence of $\mathrm{Cr}$ in the sample analysis for tank $241-\mathrm{T}-105$ is higher than expected if the sample is predominantly CW. However, other indications, based on the analyses, suggest some mixing of the $1 \mathrm{C}$ and $2 \mathrm{C}$ wastes with the $\mathrm{CW}$.

Iron. The reference Fe inventory predicted by this assessment is somewhat smaller than for the HDW model inventory. This evaluation does not predict a corrosion source-term for Fe, and may explain the smaller inventory for this assessment.

The analytical-based inventory for Fe is much higher. If the sample is predominantly $\mathrm{CW}$, no Fe should be expected except from corrosion. Iron additions from the $1 \mathrm{C}$ and $2 \mathrm{C}$ flowsheet should not account for this much Fe. The higher density basis used for calculations and/or much higher corrosion than expected are possible explanations for the higher analytical values.

Aluminum. The $\mathrm{Al}$ inventory predicted by this independent assessment and the samplebased $\mathrm{Al}$ inventory are significantly higher than that predicted by the HDW model. The sample-based inventory represents primarily $\mathrm{CW}$ and probably does not represent the entire tank. The estimated $\mathrm{Al}$ for the tank is approximately eight-fold higher than that predicted by the HDW model. This assessment assumes 100 percent of the $\mathrm{Al}$ in the $1 \mathrm{C}$ and $\mathrm{CW}$ waste partitions to the solids (based on tanks 241-T-104 and 241-U-204). The HDW model assumes that only a small percent of the Al partitions to the solids in $1 \mathrm{C} 2$ waste. The HDW model does not predict $\mathrm{CW}$ (which contains significant amounts of $\mathrm{Al}$ ) in the tank.

Manganese. This assessment and the HDW model predict no Mn in tank 241-T-105. Records do not indicate additions of $\mathrm{Mn}$ as part of the flowsheet. However, significant quantities of $\mathrm{Mn}$ were detected in the sample. The source may be waste from decontamination of equipment at $\mathrm{T}$ Plant using $\mathrm{KMnO}_{4}$. Agnew et al. (1996b) shows that decontamination waste was added to tank 241-T-105 in 1968 and 1969. Based on the sample analysis (which probably does not represent the entire tank) a total of $7.0 \mathrm{MT} \mathrm{Mn}$ is present. It is expected that the inventory of Mn is significantly less than 7.0 MT.

Sodium. The small amount of $\mathrm{Na}$ assumed in this assessment to partition to the solids results in an estimated inventory that compares well with the HDW model. 
Silicon. The reference Si inventory predicted by this assessment compares well with the sample-based inventory but is approximately five times that predicted by the HDW model. The apparent explanation is that this assessment assumes that all $\mathrm{Si}$ precipitates, and the HDW model assumes a significant portion of the $\mathrm{Si}$ is in the aqueous stream sent to cribs. In addition, the HDW model does not predict $\mathrm{CW}$ waste (which contains significant amounts of $\mathrm{Si}$ in the tank.

Fluoride. The reference inventory predicted by this assessment and the HDW model inventory are comparable, but the inventory based on the tank 241-T-105 samples is much lower. This assessment assumed that a small fraction of the $F$ in the tank remains as insoluble compounds. The analytical-based inventory results from analysis of the aqueous portion generated from water leaching of the sample. The water insoluble solids may contain $F$, but it is not possible to determine how much until an analytical method that measures total $F$ is used. It is not surprising that the sample-based inventory for fluoride is quite low because it is suspected that the sample represented primarily $\mathrm{CW}$.

Potassium. The flowsheets for 1C, 2C, and CW (see Table D3-1) do not indicate additions of $\mathrm{K}$ as part of the flowsheets. The HDW model shows $\mathrm{K}$ in the $1 \mathrm{C}$ defined waste. It is probably present as a contaminant from sodium hydroxide which was used to neutralize the acidic wastes. Analyses indicate the presence of $\mathrm{K}$, thus providing substantive evidence that $\mathrm{K}$ entered the tank as a contaminant. In addition, evidence shows (Agnew et al. 1996b) that $\mathrm{K}$ may have been added (as $\mathrm{KMnO}_{4}$ ) from decontamination activities at $\mathrm{T}$ Plant.

Nitrate. The $\mathrm{NO}_{3}$ inventory predicted by this assessment is approximately 50 percent higher than that predicted by the $\mathrm{HDW}$ model. The $\mathrm{HDW}$ model assumes all $\mathrm{NO}_{3}$ remains in the aqueous phase, and this assessment assumes (based on tanks 241-T-104 and 241-B-111) that some $\mathrm{NO}_{3}$ partitions to the solids. The sample-based inventory for $\mathrm{NO}_{3}$ is significantly lower. However, because the sample-based inventory probably represents $\mathrm{CW}$, the concentration of $\mathrm{NO}_{3}$ is expected to be lower (see Table D2-1).

Nitrite. This assessment does not account for any $\mathrm{NO}_{2}$ from radiolysis of $\mathrm{NO}_{3}$ or any $\mathrm{NO}_{2}$ additions for corrosion control purposes. This assessment and the HDW model predict small inventories of nitrite from $1 \mathrm{C}$ waste. As would be expected, the sample analysis also indicates $\mathrm{NO}_{2}$ since it provided a significant contribution to $\mathrm{CW}$.

Phosphate. The $\mathrm{PO}_{4}$ inventory predicted by this assessment is approximately six times higher than that predicted by the HDW model and sample analyses. The assumptions used in this assessment for partitioning the $\mathrm{PO}_{4}$ between solid and aqueous phases are based on calculated PFs for tanks that contain only $1 \mathrm{C}$ and $2 \mathrm{C}$ waste (that is, tanks 241-T-104 and 241-B-111, respectively). These waste types are higher in $\mathrm{PO}_{4}$ than $\mathrm{CW}$. However, for reasons explained earlier, the PF for components with mixed waste types may vary. 
Sulfate. The HDW inventory is only about one-fourth that estimated by this evaluation. The $\mathrm{HDW}$ model assumed that the $\mathrm{SO}_{4}$ partitions entirely to the aqueous phase, and this assessment assumes some $\mathrm{SO}_{4}$ partitions to the solids based on the inventory evaluations from tanks 241-T-104 and 241-B-111.

\section{D4.0 DEFINE THE BEST-BASIS AND ESTABLISH COMPONENT INVENTORIES}

Information about chemical, radiological, and/or physical properties is used to perform safety analyses, engineering evaluations, and risk assessments associated with waste management activities, as well as regulatory issues. These activities include overseeing tank farm operations and identifying, monitoring, and resolving safety issues associated with these operations and with the tank wastes. Disposal activities involve designing equipment, processes, and facilities for retrieving wastes and processing them into a form that is suitable for long-term storage. Chemical and radiological inventory information are generally derived using three approaches: (1) component inventories are estimated using the results of sample analyses, (2) component inventories are predicted using the HDW model based on process knowledge and historical information, or (3) a tank-specific process estimate is made based on process flowsheets, reactor fuel data, essential material usage and other operating data. The information derived from these different approaches is often inconsistent.

An effort is underway to provide waste inventory estimates that will serve as the standard characterization for management activities (Kupfer et al. 1995). As part of this effort, an evaluation of available chemical information for tank 241-T-105 was performed including the following:

- Data from two core composite samples from tank 241-T-105 collected in 1993.

- Data from three tanks that contain the same waste types $(1 \mathrm{C}, 2 \mathrm{C}$, and $\mathrm{CW})$ as found in tank 241-T-105. The three tanks that represent $1 \mathrm{C}, 2 \mathrm{C}$, and $\mathrm{CW}$ waste are tanks 241-T-104, 241-B-111, and 241-U-204, respectively.

- Inventory estimate generated by the HDW model (Agnew et al. 1996a). 
The results from this evaluation support using a predicted inventory based primarily on analytical results for tanks $241-\mathrm{T}-104,241-\mathrm{B}-111$, and $241-\mathrm{U}-204$ as the basis for the bestestimate inventory to tank 241-T-105 for the following reasons:

1. Waste transactions based on Anderson (1990) for tank 241-T-105 show significant quantities of $\mathrm{CW}$ solids and waste solids from the first and second contamination cycles of the $\mathrm{BiPO}_{4}$ process. The HDW model (Agnew et al. 1996a) predicts only $1 \mathrm{C}$ and $2 \mathrm{C}$ waste layers in the tank although the analytical data based on the 1993 core samples from tank 241-T-105 are considered poor because solids recovery was low. The analytical results indicate that waste from this sample contained primarily $\mathrm{CW}$.

2. Because waste recovery for the two core samples from tank 241-T-105 was incomplete, it is unlikely that the sample-based inventory represents the entire tank. However, radionuclide distribution in the samples appears to represent the tank, based on heat load estimate.

3. The solubility data in Agnew et al (1996a) for several chemical components are not consistent with the analytical data for tanks that contain only $1 \mathrm{C}$ and 2C waste (tanks 241-T-104 and 241-B-111, respectively).

Because of the limited sample recovery, the sample data for tank 241-T-105 are not considered representative of the entire tank contents. As a result, the analytical-based inventories for tanks 241-T-104, 241-B-111, and 241-U-204 were used to derive the bestbasis inventory of chemical components that were added to tank $241-\mathrm{T}-105$ from process flowsheet additions. The analytical results from tanks 241-T-104, 241-B-111, and 241-U-204, which contain only $1 \mathrm{C}, 2 \mathrm{C}$, and $\mathrm{CW}$, respectively, agree with predicted inventories for these tanks based on process flowsheets and waste fill history. Assessments have shown that the analytical-based compositions for these tanks can be extrapolated to the same waste types in other tanks, particularly if the tanks are in a cascade arrangement. The assumptions regarding the representativeness of tank samples must be considered speculative at this time with resolution provided by possible future resampling of this tank.

Inventories for components, which were not added from the process flowsheets, are based on the core samples from tank 241-T-105. All radionuclide inventories are based on the sample analysis of tank 241-T-105. Radionuclide curie values are decayed to January 1, 1994.

Best-basis inventory estimates for tank 241-T-105 are shown in Tables D4-1 and D4-2. The quality of the estimate for chemical and radionuclide components is considered low because the inventories are either extrapolated from data from other tanks (241-T-105, 241-B-111, and 241-U-204), or they are based on sample results from tank 241-T-105 that are considered biased. 
HNF-SD-WM-ER-369 Rev. 1

Table D4-1. Best-Basis Inventory Estimates for Nonradioactive

Components in Tank 241-T-105 (September 30, 1996). (2 sheets)

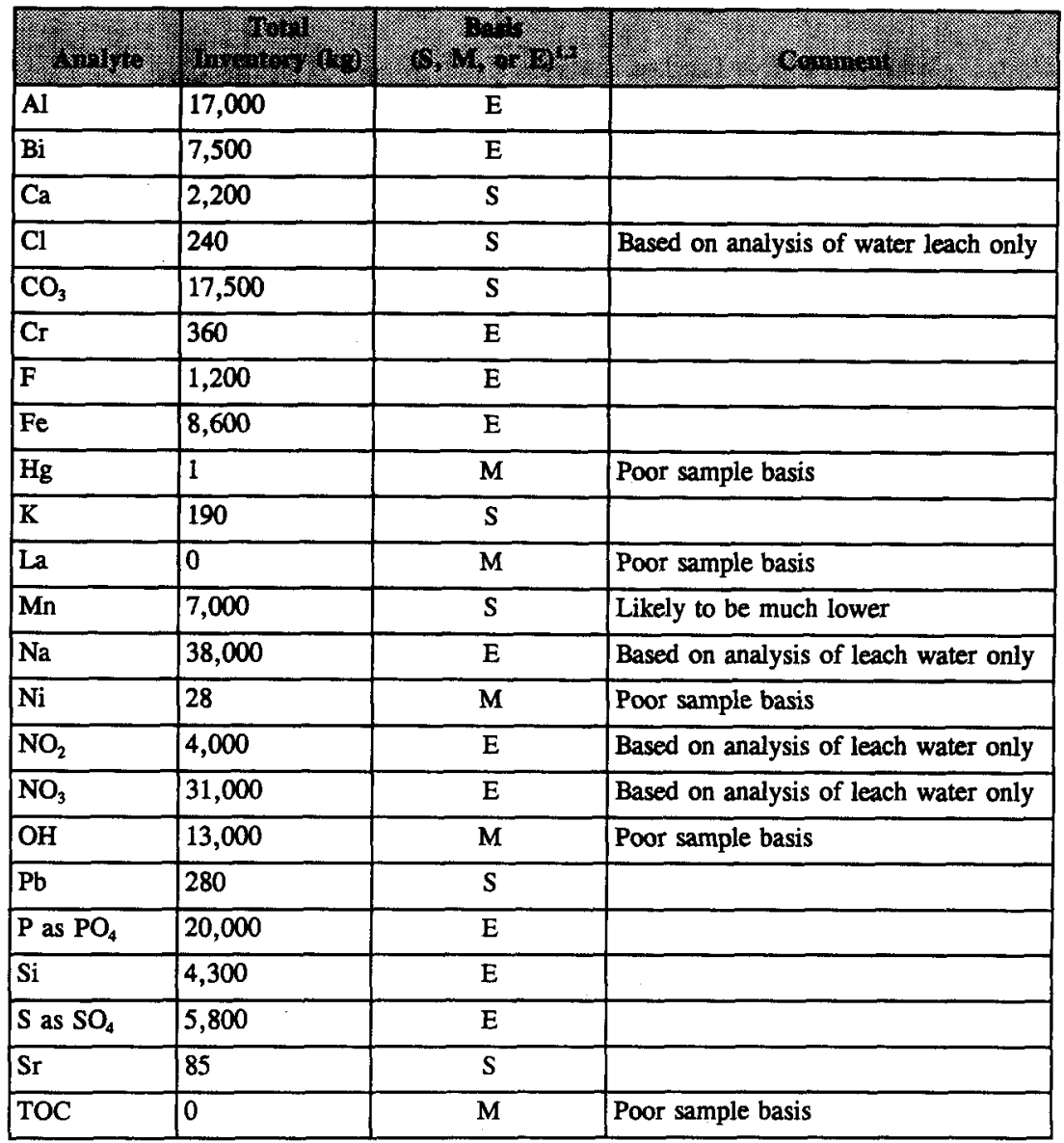


HNF-SD-WM-ER-369 Rev. 1

Table D4-1. Best-Basis Inventory Estimates for Nonradioactive Components in Tank 241-T-105 (September 30, 1996). (2 sheets)

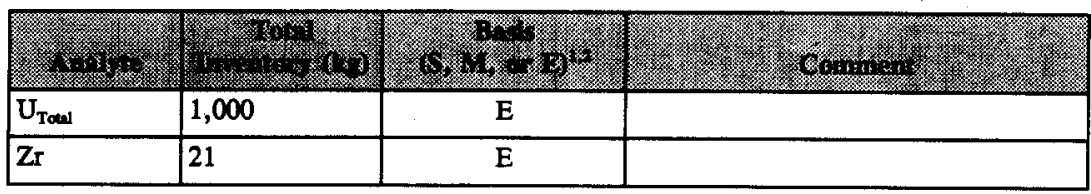

Notes:

'S = Sample-based, $\mathbf{M}=$ Hanford Defined Waste model-based, $\mathrm{E}=$ Engineering assessment-based from tanks 241-T-104, 241-B-111, and 241-U-204

${ }^{2}$ Sampie based inventories were based on partial cores with poor recovery (see Appendix B). 
Table D4-2. Sample-Based Best-Basis Inventory Estimates for Radioactive Components for Tank 241-T-105 (All Curie Values Decayed to January 1, 1994).

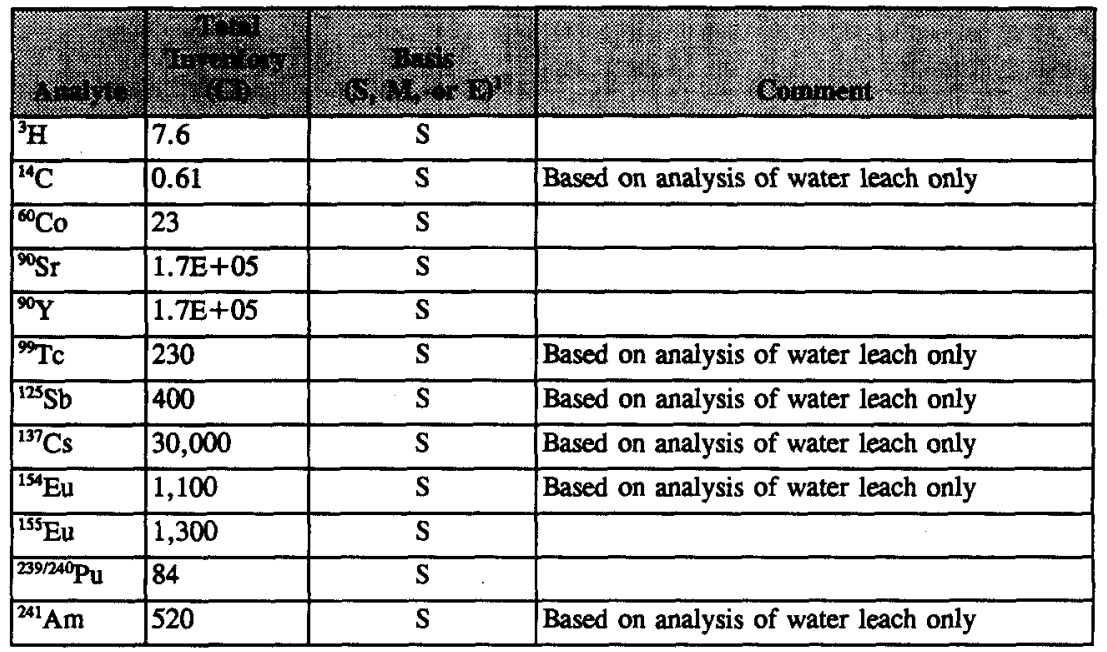

Notes:

'S = Sample-based, $M=$ Hanford Defined Waste model-based, $E$ = Engineering assessment-based from tanks 241-T-104, 241-B-111, and 241-U-204

${ }^{2}$ Sample based inventories were based on partial cores with poor recovery (see Appendix B). 


\section{D5.0 APPENDIX D REFERENCES}

Anderson, J. D., 1990, A History of the 200 Area Farms, WHC-MR-0132, Westinghouse Hanford Company, Richland, Washington.

Agnew, S. F., J. Boyer, R. Corbin, T. Duran, J. FitzPatrick, K. Jurgensen, T. Ortiz, and B. Young, 1996a, Hanford Tank Chemical and Radionuclide Inventories: HDW Model Rev. 3, LA-UR-96-858, Los Alamos National Laboratory, Los Alamos, New Mexico.

Agnew, S. F., R. A. Corbin, T. B. Duran, and K. A. Jurgensen, T. P. Ortiz and B. L. Young, 1996b, Waste Status and Transaction Record Summary for the Northwest Quadrant of the Hanford 200 Area, WHC-SD-WM-TI-669, Rev. 1, Westinghouse Hanford Company, Richland, Washington.

Hanlon, B. M., 1996, Waste Tank Summary Report for Month Ending August 31 , 1996, WHC-EP-0182-101, Westinghouse Hanford Company, Richland, Washington.

Hill, J. G., G. S. Anderson, and B. C. Simpson, 1995, The Sort on Radioactive Waste Type Model: A Method to Sort Single-Shell Tanks into Characteristic Groups, PNL-9814, Rev: 2, Pacific Northwest Laboratory, Richland, Washington.

Kupfer, M. J., M. D. LeClair, W. W. Schulz, and L. W. Shelton, 1995, Work Plan for Defining A Standard Inventory Estimate for Wastes Stored in Hanford Site Underground Tanks, WHC-SD-WM-WP-311, Rev. 0, Westinghouse Hanford Company, Richland, Washington.

Schneider, K. L., 1951, Flow Sheets and Flow Diagrams of Precipitation Separations Process, HW-23043, Hanford Atomic Products Operation, Richland, Washington. 
HNF-SD-WM-ER-369 Rev. 1

This page intentionally left blank. 
HNF-SD-WM-ER-369 Rev. 1

APPENDIX E

BIBLIOGRAPHY FOR TANK 241-T-105

E-1 
HNF-SD-WM-ER-369 Rev. 1

This page intentionally left blank. 


\section{APPENDIX E}

\section{BIBLIOGRAPHY FOR TANK 241-T-105}

Appendix E provides a bibliography that supports the characterization of tank 241-T-105. This bibliography is an in-depth literature search of all known information sources that provide sampling, analysis, surveillance, and modeling information, as well as processing occurrences associated with tank 241-T-105 and its respective waste types.

The references in this bibliography are separated into three broad categories containing references broken down into subgroups. These categories and their subgroups are listed below.

\section{NON-ANALYTICAL DATA}

Ia. Models/Waste Type Inventories/Campaign Information

Ib. Fill History/Waste Transfer Records

Ic. Surveillance/Tank Configuration

Id. Sample Planning/Tank Prioritization

Ie. Data Quality Objectives/Customers of Characterization Data

\section{ANALYTICAL DATA - SAMPLING OF TANK WASTE AND WASTE TYPES}

IIa. Sampling of Tank 241-T-105

IIb. Sampling of $1 \mathrm{C}, 2 \mathrm{C}$, and $\mathrm{CW}$ Waste Types

\section{COMBINED ANALYTICAL/NON-ANALYTICAL DATA}

IIIa. Inventories using Campaign and Analytical Information

IIIb. Compendium of Existing Physical and Chemical Documented Data Sources

This bibliography is broken down into the appropriate sections of material to use, with an annotation at the end of each reference describing the information source. Where possible, a reference is provided for information sources. A majority of the information listed below may be found in the Lockheed Martin Hanford Corporation Tank Characterization Resource Center. 


\section{NON-ANALYTICAL DATA}

Ia. Models/Waste Type Inventories/Campaign Information

Anderson, J. D., 1990, A History of the 200 Area Farms, WHC-MR-0132, Westinghouse Hanford Company, Richland, Washington.

- Contains single-shell tank fill history and primary campaign/waste type information to 1981 .

Jungfleisch, F. M. and B. C. Simpson, 1993, Preliminary Estimation of the Waste Inventories in Hanford Tanks Through 1980, WHC-SD-WM-TI-057, Rev. 0-A, Westinghouse Hanford Company, Richland, Washington.

- A model based on process knowledge and radioactive decay estimations for different compositions of process waste streams assembled for total, solution, and solids compositions per tank. Assumptions about waste/waste types and solubility parameters/ constraints are also given.

Hodgson, K. M and M. D. LeClair, 1996, Work Plan for Defining A Standard Inventory Estimate for Wastes Stored in Hanford Site Underground Tanks, WHC-SD-WM-WP-311, Rev. 1, Westinghouse Hanford Company, Richland, Washington.

- Gives plan for defining a standard inventory estimate for wastes stored in tanks at Hanford.

Schneider, K. J., 1951, Flow Sheet and Flow Diagrams of Precipitation Separations process, HW-23043, General Electric Company, Richland, Washington.

- Contains compositions of first cycle waste before transfer to $200 \mathrm{E}$ waste tanks.

Ib. Fill History/Waste Transfer Records

Agnew, S. F., R. A. Corbin, T. B. Duran, K. A. Jurgensen, T. P. Ortiz, and B. L. Young, 1996, Waste Status and Transaction Record Summary for the Northwest Quadrant of the Hanford 200 East Area, WHC-SD-WM-TI-669, Rev. 1, Westinghouse Hanford Company, Richland, Washington.

- Contains spreadsheets showing all available data on tank additions/transfers. 
Agnew, S. F., J. Boyer, R. A. Corbin, T. B. Duran, J. FitzPatrick, K. A. Jurgensen, T. P. Ortiz, and B. L. Young, 1996, Hanford Tank Chemical and Radionuclide Inventories: HDW Model Rev. 3, LA-UR-96-858, Los Alamos National Laboratory, Los Alamos, New Mexico.

- Contains estimates for the chemical and radionuclide compositions of the 177 Hanford High-Level Waste storage tanks. Develops a model called the Hanford Defined Waste Model.

Anderson, J. D., 1990, A History of the 200 Area Tank Farms, WHC-MR-0132, Westinghouse Hanford Company, Richland, Washington.

- Contains single-shell tank fill history and primary campaign/waste type information up to 1981.

Ic. Surveillance/Tank Configuration

Alstad, A. T., 1993, Riser Configuration Document for Single-Shell Waste Tanks, WHC-SD-RE-TI-053, Rev. 9, Westinghouse Hanford Company, Richland, Washington.

- Shows tank riser locations in relation to tank aerial view as well as a description of riser and its contents.

Bergmann, L. M., 1991, Single-Shell Tank Isolation Safety Analysis Report, WHC-SD-WM-SAR-006, Rev. 2, Westinghouse Hanford Company, Richland, Washington.

- Contains safety analysis report on isolation of single-shell tanks.

Baumhardt, R. J., 1988, Interim Isolation of Tanks 105-T, 109-T and 104-S (Letter 8856251 to R. E. Gerton, October 12, 1988), Westinghouse Hanford Company, Richland, Washington.

- Documents interim isolation of tank 241-T-105 on September 30, 1988.

Lipnicki, J., 1996 Waste Tank Risers Available for Sampling, WHC-SD-WM-TI-710, Rev. 3 Westinghouse Hanford Company, Richland, Washington.

- Assesses riser locations for each tank; however not all tanks are included/completed. Includes estimate of what risers are available for sampling. 
Swaney, S. L., 1994, Single-Shell Tank Stabilization Record, WHC-SD-RE-178, Rev. 4, Westinghouse Hanford Company, Richland, Washington.

- Contains information about the stabilization of single-shell tanks.

Tran, T. T., 1993, Themocouple Status Single-Shell and Double-Shell Waste Tanks, WHC-SD-WM-TI-553, Rev. 0, Westinghouse Hanford Company, Richland, Washington.

- Contains information about the status of thermocouples in the Hanford Tanks.

Vitro Engineering Corporation, 1988, Piping Waste Tank Isolation 241-T-105, H-2-73062, Rev. 4, Vitro Engineering Corporation, Richland, Washington.

- Contains information about piping.

Welty, R. K., 1988, Waste Storage Tank Status and Leak Detection Criteria, WHC-SD-WM-TI-356, Vol. 1, Westinghouse Hanford Company, Richland, Washington.

- Describes the nature, scope, and frequency of surveillance employed for waste storage tanks, states action criteria for response to data deviations, and presents tank data reviews between June 15, 1973, and June 15, 1988.

Id. Sample Planning/Tank Prioritization

Bell, K. E., 1993, Tank Waste Remediation System Tank Waste Characterization Plan, WHC-SD-WM-PLN-047, Rev. 1, Westinghouse Hanford Company, Richland, Washington.

- Provides an integrated approach to the characterization of Hanford Site tank waste samples. The scope of this plan is defined by the characterization activities necessary for safely storing, maintaining, treating, and disposing onsite, or packaging for offsite disposal, all tank wastes.

Brown, T. M., S. J. Eberlein, J. W. Hunt and T. J. Kunthara, 1996, Tank Waste Characterization Basis, WHC-SD-WM-TA-164, Rev. 2, Westinghouse Hanford Company, Richland, Washington. 
- Summarizes the technical basis for characterizing the waste in the tanks and assigns a priority number to each tank.

Grimes, G. W., 1977, Hanford Long-Term Defense High-Level Waste Management Program Waste Sampling and Characterization Plan, RHO-CD-137, Rockwell Hanford Operations, Richland, Washington.

- Early characterization planning document.

Public Law 101-510, 1990, "Safety Measures for Waste Tanks at Hanford Nuclear Reservation," Section 3137 of National Defense Authorization Act for Fiscal Year 1991.

- Provides information regarding safety measures for waste stored in tanks at the Hanford Site.

Rich, H. B., and L. M. Sasaki, 1993, Letter of Instruction for Physical Analysis of Single Shell Tank 241-T-105 Core 57, (Letter 9355141 to A. G. King of PNL, June 21, 1993), Westinghouse Hanford Company, Richland, Washington.

- Provides instructions for physical analyses of Core 57 samples by the PNL 325 laboratory.

Waldo, E. J., 1993, Core Sampling Recovery Test Strategy, WHC-SD-WM-TP-120, Rev. 0, Westinghouse Hanford Company, Richland, Washington.

Reservation, Section 3137 of National Defense Authorization Act for Fiscal Year 1991.

- Provides information regarding safety measures for waste stored in tanks at the Hanford Site.

Winkelman, W. W., J. W. Hunt, and L. J. Fergestrom, 1996, FY 1996 Tank Waste Analysis Plan, WHC-SD-WM-PLN-101, Rev. 0, Westinghouse Hanford Company, Richland, Washington.

- Contains Tri-Party Agreement (see Ecology et al. [1994] listing in Section 5.0) requirement-driven TWRS Characterization Program information and a list of tanks addressed in fiscal year 1996. 
Winters, W. I., L. Jensen, L. M. Sasaki, R. L. Weiss, J. F. Keller, A. J. Schmidt, and M. G. Woodruff, 1989, Waste Characterization Plan for the Hanford Site Single-Shell Tanks, WHC-EP-0210, Westinghouse Hanford Company, Richland, Washington.

- Early version of characterization planning document.

Ie. Data Quality Objectives (DQO) and Customers of Characterization Data

Dukelow, G. T., J. W. Hunt, H. Babad, and J. E. Meacham, 1995, Tank Safecy Screening Data Quality Objective, WHC-SD-WM-SP-004, Rev. 2, Westinghouse Hanford Company, Richland, Washington.

- DQO used to determine whether tanks operate under safe conditions.

\section{ANALYTICAL DATA - SAMPLING OF TANK WASTE AND WASTE TYPES}

Ila. Sampling of Tank 241-T-105

Cromar, R. D., S. R. Wilmarth, and L. Jensen, 1994, Statistical Characterization Report for Single-Shell Tank 241-T-105, WHC-SD-WM-TI-653, Westinghouse Hanford Company, Richland, Washington.

- Contains statistical characterization report for tank 241-T-105.

Giamberardini, K. K., 1993, 222-S Laboratories Single-Shell Tank Waste Characterization, Tank-T-105 Core 57 Data Package, WHC-SD-WM-DP-040, Rev. 0, Westinghouse Hanford Company, Richland, Washington.

- Contains data package for core 57.

Godfrey, W. L., 1965, 242-T Evaporator Feed (internal letter to S. J. Beard, dated September 24), General Electric Company, Richland, Washington.

- Contains 242-T Evaporator feed analytical results.

Herting, D. L., 1993, Mass/Charge for Tank T-105, (internal memorandum 12110-PCL93-084 to K. L. Kocher, dated September 28), Westinghouse Hanford Company, Richland, Washington. 
- Contains mass and charge balance for tank 241-T-105. The calculations are based on the 1993 sampling event.

Kocher, K. L., 1993, WHC-222-S and PNL Laboratories Single-Shell Tank Waste Characterization, Tank T-105 Cores 53 and 54 Data Packages (Narrative) and Validation Summaries, WHC-SD-WM-DP-047, Rev. 0, Westinghouse Hanford Company, Richland, Washington.

- Data packages for the data from cores 53 and 54, obtained from tank 241-T-105 in 1993.

Sasaki, L. M., 1993, Letter of Instruction for Extrusion of Core Samples During Core Sampling Recovery Testing, (internal memorandum 7K220-93-045 to J. G. Kristofzski, dated May 24), Westinghouse Hanford Company, Richland, Washington.

- Provides instructions to the 222-S Laboratory for extrusion of sample.

Sasaki, L. M., 1993, Letter of Instruction on Tank 24I-T-105 Core 57 Analytical Requirements, (internal memorandum 7K220-93-052 to J. G. Kristofzski, dated June 16), Westinghouse Hanford Company, Richland, Washington.

- Provides confirmation of sample being sent to 325 Laboratory.

Silvers, K. L., and L. M. Sasaki, 1993, Letter of Instruction for Tank T-105 Analysis Priorities, (internal memorandum 7K220-93-022 to K. L. Kocher, dated April 20), Westinghouse Hanford Company, Richland, Washington.

- Prioritizes the analyses of samples collected in 1993.

Wheeler, R. E., 1974, Analysis of Tank Farm Samples Sample: T-4927, 105T, Atlantic Richfield Hanford Company, Richland, Washington.

- Documents the analysis of sample T-4927.

IIb. Sampling of $1 \mathrm{C}, 2 \mathrm{C}$, and $\mathrm{CW}$ Waste Types

Raphael, G. F. and T. T. Tran, 1995, Tank Characterization Report for Single-Shell Tank 241-U-204, WHC-SD-WM-ER-486, Rev. 0, Westinghouse Hanford Company, Richland, Washington. 
- Summarizes the information on the historical uses, present status, and the sampling and analysis results of waste stored in tank 241-U-204. Used as typical of $\mathrm{CW}$ waste type.

Remund, K. M., J. M. Tingey, P. G. Heasler, J. J. Toth, F. M. Ryan, S. A. Hartley, and C. J. Benar, 1996, Tank Characterization Report for Single-Shell Tank 241-B-111, WHC-SD-WM-ER-549, Rev. 0, Westinghouse Hanford Company, Richland, Washington.

- Provides the characterization information and interprets the data from sampling events of tank 241-B-111. Typical example of $2 \mathrm{C}$ waste type.

\section{COMBINED ANALYTICAL/NON-ANALYTICAL DATA}

IIIa. Inventories from Campaign and Analytical Information

Agnew, S. F., J. Boyer, R. A. Corbin, T. B. Duran, J. R. Fitzpatrick, K. A. Jurgensen, T. P. Ortiz, and B. L. Young, 1996, Hanford Tank Chemical and Radionuclide Inventories: HDW Rev. 3, LA-UR-96-858, Rev. 0, Los Alamos National Laboratory, Los Alamos, New Mexico.

- Contains waste type summaries and primary chemical compound/analyte and radionuclide estimates for sludge, supernatant, and solids.

Allen, G. K., 1976, Estimated Inventory of Chemicals Added to Underground Waste Tanks, 1944 - 1975, ARH-CD-601B, Atlantic Richfield Hanford Company, Richland, Washington.

- Contains major components for waste types and some assumptions. Purchase records are used to estimate chemical inventories.

Allen, G. K., 1975, Hanford Liquid Waste Inventory As Of September 30, 1974, ARH-CD-229, Atlantic Richfield Hanford Company, Richland, Washington.

- Contains major components for waste types, and some assumptions.

Brevick, C. H., L. A. Gaddis, and E. D. Johnson, 1995, Historical Tank Content Estimate for the Northwest Quadrant of the Hanford 200 Areas, WHC-SD-MW-ER-351, Rev. 0, Westinghouse Hanford Company, Richland, Washington. 
- Contains summary information from the supporting document as well as in-tank photo collages and the solid composite inventory estimates Rev. 0 and Rev. 0 A.

Schmittroth, F. A., 1995, Consequence Ranking of Radionuclides in Hanford Tank Wastes, WHC-SD-WM-RPT-163, Rev. 0, Westinghouse Hanford Company, Richland, Washington.

- Contains radionuclide analyses for Hanford tanks.

IIIb. Compendium of Data from Other Documented Physical and Chemical Data Sources.

Agnew, S. F., and J. G. Watkin, 1994, Estimation of Limiting Solubilities for Ionic Species in Hanford Waste Tank Supernates, LA-UR-94-3590, Los Alamos National Laboratory, Los Alamos, New Mexico.

- Gives solubility ranges used for key chemical and radionuclide components based on supernatant sample analyses.

Brevick, C. H., L. A. Gaddis, and E. D. Johnson, 1995, Tank Waste Source Term Inventory Validation, Vol I \& 11 ., WHC-SD-WM-ER-400, Rev. 0, Westinghouse Hanford Company, Richland, Washington.

- Contains a quick reference to sampling information in spreadsheet or graphical form for 23 chemicals and 11 radionuclides for all tanks.

Brevick, C. H., L. A. Gaddis, and W. W. Pickett, 1995, Supporting Document for the Historical Tank Content Estimate for T Tank Farm, WHC-SD-WM-ER-320, Rev. 0, Westinghouse Hanford Company, Richland, Washington.

- Contains summary tank farm and tank write-ups on historical data and solid inventory estimates as well as appendices for the data. The appendices contain the following information: Appendix $\mathrm{C}$ - Level History AutoCAD sketch; Appendix D - Temperature Graphs; Appendix E - Surface Level Graph; Appendix F - Cascade/Drywell Charts; Appendix G - Riser Configuration Drawing and Table; Appendix I - In-Tank Photos; and Appendix K - Tank Layer Model Bar Chart and Spreadsheet.

Colton, N. G., 1996, "Status Report: Pretreatment Chemistry Evaluation-Wash and Leach Factors for the Single-Shell Tank Waste Inventory," PNNL-1129, Pacific Northwest National Laboratory, Richland, Washington. 
- Contains sludge wash data for all single-shell tanks evaluated since 1986.

De Lorenzo, D.S., J. H. Rutherford, D. J. Smith, D. B. Hiller, and K. W. Johnson, 1994, Tank Characterization Reference Guide, WHC-SD-WM-648, Westinghouse Hanford Company, Richland, Washington.

- Provides a broad background of information relating to the characterization of Hanford Site tank wastes.

Dukelow, G. T., 1975, Increasing Dry Well Radiation Levels Adjacent to Waste Tanks T-105 \& T-108, OR-75-02, Atlantic Richfield Hanford Company, Richland, Washington.

- Contains information about increased radiation in dry well 50-04/05-10.

Hartley, S. A., G. Chen, C. A. Lopresti, T. A. Ferryman, Liebetrau, K. M. Remund, and S. A. Allen, 1996, A Comparison of Historical Tank Contents Estimates (HTCE) Model, Rev. 3, and Sample Based Estimates, PNNL-11429, Pacific Northwest National Laboratory, Richland, Washington.

- Contains a statistical evaluation of the HDW inventory estimate against analytical values from 12 existing TCR reports using a select component data set.

Hanlon, B. M., 1996, Waste Tank Summary Report for Month Ending August 31, 1996, WHC-EP-0182-101, Westinghouse Hanford Company, Richland, Washington.

- Contains a monthly summary of the following: fill volumes, Watch List tanks, occurrences, integrity information, equipment readings, equipment status, tank location, and other miscellaneous tank information.

Husa, E. I., 1993, Hanford Site Waste Storage Tank Information Notebook, WHC-EP-0625, Westinghouse Hanford Company, Richland, Washington.

- Contains in-tank photos and summaries on the tank description, leak detection system, and tank status. 
Husa, E. I., 1995, Hanford Waste Tank Preliminary Dryness Evaluation, WHC-SD-WM-TI-703, Rev. 0, Westinghouse Hanford Company, Richland, Washington.

- Assesses relative dryness between tanks.

Jensen, H. F., 1974, Symptoms of Leakage from Liquid Level Drop and Dry Well Activity in Waste Tank T-105, OR-74-108, Atlantic Richfield Hanford Company, Richland, Washington.

- Contains information about increased radiation in dry well 50-09-10.

Remund, K. M. And B. C. Simpson, 1996, Hanford Waste Tank Grouping Study, PNNL-11433, Pacific Northwest National Laboratory, Richland, Washington.

- Contains a statistical evaluation to group tasks into classes with similar waste properties.

Shelton, L. W., 1996, Chemical and Radionuclide Inventory for Single and Double Shell Tanks, (internal memorandum 74A20-96-30, to D. J. Washenfelder, dated February 28), Westinghouse Hanford Company, Richland, Washington.

- Contains an tank inventory estimate based on analytical information.

Shelton, L. W., 1995, Chemical and Radionuclide Inventory for Single- and Double-Shell Tanks, (internal memorandum 75520-95-007, to R. M. Orme, dated August 8), Westinghouse Hanford Company, Richland, Washington.

- Contains a tank inventory estimate based on analytical information.

Shelton, L. W., 1995, Radionuclide Inventories for Single- and Double-Shell Tanks, (internal memorandum to F. M. Cooney, 71320-95-002, dated February 14), Westinghouse Hanford Company, Richland, Washington.

- Contains a tank inventory estimate based on analytical information. 
HNF-SD-WM-ER-369 Rev. 1

This page intentionally left blank. 


\begin{tabular}{|c|c|c|c|c|c|}
\hline \multicolumn{6}{|c|}{ DISTRIBUTION SHEET } \\
\hline \multirow[b]{2}{*}{ Distribution } & \multirow{2}{*}{\multicolumn{3}{|c|}{$\begin{array}{c}\text { From } \\
\text { Data Assessment and } \\
\text { Interpretation }\end{array}$}} & \multicolumn{2}{|l|}{ Page 1 of 4} \\
\hline & & & & \multicolumn{2}{|c|}{ Date $\quad 01 / 21 / 97$} \\
\hline \multirow{2}{*}{\multicolumn{4}{|c|}{$\begin{array}{l}\text { Project Title/work Order } \\
\text { Tank Characterization Report for Single-She11 Tank 241-T-105, } \\
\text { WHC-SD-WM-ER-369. Rev. } 1\end{array}$}} & \multicolumn{2}{|c|}{ EDT No. N/A } \\
\hline & & & & \multicolumn{2}{|c|}{ ECN No. 635417} \\
\hline Name & MSIN & $\begin{array}{l}\text { Text } \\
\text { With } \\
\text { All } \\
\text { Attach }\end{array}$ & $\begin{array}{l}\text { Text } \\
\text { Only }\end{array}$ & $\begin{array}{l}\text { Attach. } \\
\text { Appendi } \\
x \\
\text { Only }\end{array}$ & $\begin{array}{c}\text { EDT/ECN } \\
\text { Only }\end{array}$ \\
\hline
\end{tabular}

OFFSITE

Sandia National Laboratory

P.0. Box 5800

MS-0744. Dept. 6404

Albuquerque, NM 87815

D. Powers

$x$

Nuclear Consulting Services Inc.

P. 0. Box 29151

Columbus, OH 43229-01051

J. L. Kovach

$\times \quad \cdot$

Chemical Reaction Sub-TAP

P. 0. Box 271

Lindsborg, KS 67456

B. C. Hudson

$x$

Tank Characterization Panel

Senior Technical Consultant

Contech

7309 Indian School Road

Albuquerque. NM 87110

J. Arvisu

$x$

SAIC

20300 Century Boulevard. Suite 200-B

Germantown, MD 20874

H. Sutter

$x$

555 Quince Orchard Rd., Suite 500

Gaithersburg. MD 20878

P. Szerszen 

THIS PAGE INTENTIONALLY
LEFT BLANK 


\section{DISTRIBUTION SHEET}

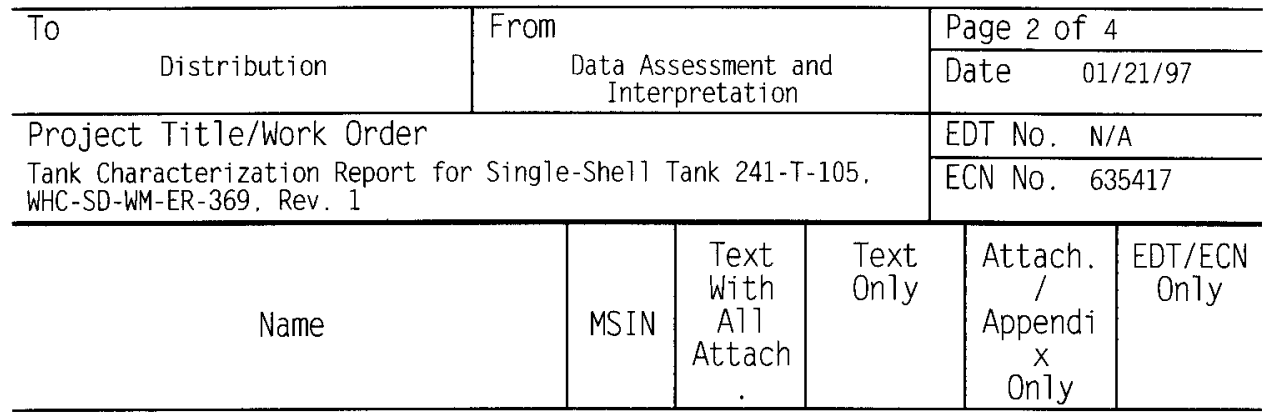

Los Alamos Laboratory

CST-14 MS-J586

P. 0 . Box 1663

Los Alamos. NM 87545

S. F. Agnew

$x$

Los Alamos Technical Associates

T. T. Tran

B1-44

$x$

Ogden Environmental

101 East Wellsian Way

Richland. WA 99352

R. J. Anema

$x$

CH2M Hill

P. 0. BoX 91500

Bellevue. WA 98009-2050

M. McAfee

$x$

Tank Advisory Panel

102 Windham Road

Oak Ridge, TN 37830

D. O. Campbe11

$x$

\section{ONSITE}

Department of Energy - Richland Operations

J. F. Thompson

W. S. Liou

J. A. Poppiti

N. W. Willis
S7-54 $\quad x$

S7. $54 \quad x$

$57-54 \quad x$

$57-54 \quad x$ 
THIS PAGE INTENTIONALLY LEFT BLANK 


\section{DISTRIBUTION SHEET}

\begin{tabular}{|c|c|c|c|c|c|}
\hline \multirow{2}{*}{ Do Distribution } & \multirow{2}{*}{\multicolumn{3}{|c|}{$\begin{array}{c}\text { From } \\
\begin{array}{c}\text { Data Assessment and } \\
\text { Interpretation }\end{array} \\
\end{array}$}} & \multicolumn{2}{|c|}{ Page 3 of 4} \\
\hline & & & & \multicolumn{2}{|c|}{ Date $\quad 01 / 21 / 97$} \\
\hline \multirow{2}{*}{\multicolumn{4}{|c|}{$\begin{array}{l}\text { Project Title/Work Order } \\
\text { Tank Characterization Report for Single-She11 Tank 241-T-105, } \\
\text { WHC-SD-WM-ER-369. Rev. } 1\end{array}$}} & \multirow{2}{*}{\multicolumn{2}{|c|}{$\begin{array}{ll}\text { EDT No. } & \text { N/A } \\
\text { ECN No. } & 635417\end{array}$}} \\
\hline & & & & & \\
\hline \multicolumn{2}{|l|}{ Name } & $\begin{array}{l}\text { Text } \\
\text { With } \\
\text { AךT } \\
\text { Attach }\end{array}$ & $\begin{array}{l}\text { Text } \\
\text { Only }\end{array}$ & $\begin{array}{c}\text { Attach. } \\
/ \\
\text { Appendi } \\
x \\
\text { Only }\end{array}$ & $\begin{array}{l}\text { EDT/ECN } \\
\text { Only }\end{array}$ \\
\hline
\end{tabular}

DE\&S Hanford, Inc.

W. L. Cowley

G. L. Dunford

G. D. Johnson

J. E. Meacham

Fluor Daniel Northwest

J. L. Stroup

Lockheed Martin Hanford, Corp.

K. M. Hodgson

T. J. Kelley

N. W. Kirch

L. M. Sasaki

B. C. Simpson

ERC (Environmental Resource Center)

Tank Characterization Resource Center

Lockheed Martin Services, Inc.

B. G. Lauzon

Central files

EDMC

Numatec Hanford Corporation

J. S. Hertzel

D. L. Lamberd

Pacific Northwest Laboratory

J. R. Gormsen

A. F. Noonan

Rust Federa7 Services of Hanford. Inc.

C. T. Narquis

$\begin{array}{ll}\text { R2 }-54 & X \\ \text { A2 }-34 & X \\ \text { S7-14 } & X \\ \text { S7-14 } & X\end{array}$

S3-09 $\quad x$

H0-34 X

S7-21 $\quad X$

R2-11 $X$

$R 2-12 \quad X$

$R 2-12 \cdot x$

R1-51 $\quad X$

R2-12 5

R1-08 $X$

A3-88 $\quad x$

H6-08 $\quad X$

H5-61 X

H5-61 X

K7 $-28 \quad X$

K9-91 $\quad x$

T6-16 $\quad x$ 
THIS PAGE INTENTIONALLY LEFT BLANK 


\section{DISTRIBUTION SHEET}

\begin{tabular}{|c|c|c|c|c|c|}
\hline \multirow[b]{2}{*}{ Distribution } & \multirow{2}{*}{\multicolumn{3}{|c|}{$\begin{array}{c}\text { From } \\
\text { Data Assessment and } \\
\text { Interpretation }\end{array}$}} & \multicolumn{2}{|c|}{ Page 4 of 4} \\
\hline & & & & \multicolumn{2}{|c|}{ Date $\quad 01 / 21 / 97$} \\
\hline \multirow{2}{*}{\multicolumn{4}{|c|}{$\begin{array}{l}\text { Project Title/Work Order } \\
\text { Tank Characterization Report for Single-She11 Tank 241-T-105, } \\
\text { WHC-SD-WM-ER-369. Rev. 1 }\end{array}$}} & \multicolumn{2}{|c|}{\begin{tabular}{|ll} 
EDT No. N/A \\
\end{tabular}} \\
\hline & & & & \multicolumn{2}{|c|}{ ECN No. 635417} \\
\hline Name & MSIN & $\begin{array}{l}\text { Text } \\
\text { With } \\
\text { All } \\
\text { Attach }\end{array}$ & $\begin{array}{l}\text { Text } \\
\text { Only }\end{array}$ & $\begin{array}{c}\text { Attach. } \\
/ \\
\text { Appendi } \\
x \\
\text { Only }\end{array}$ & $\begin{array}{l}\text { EDT/ECN } \\
\text { Only }\end{array}$ \\
\hline
\end{tabular}

SGN Eurisys Services Corp.

D. B. Engelman

L6-37 X

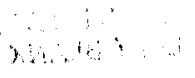



THIS PAGE INTENTIONALLY
LEFT BLANK 